\title{
SURFACE-WATER HYDROLOGY AND RUNOFF SIMULATIONS \\ FOR THREE BASINS IN PIERCE COUNTY, WASHINGTON
}

By M.C. Mastin

U.S. GEOLOGICAL SURVEY

Water-Resources Investigations Report 95-4068

Prepared in cooperation with

PIERCE COUNTY DEPARTMENT OF PUBLIC WORKS

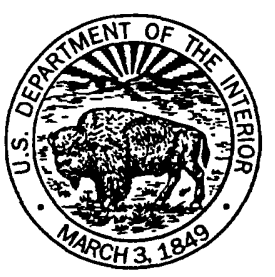

Tacoma, Washington

1996 


\section{U.S. DEPARTMENT OF THE INTERIOR}

BRUCE BABBIT, Secretary

\section{U.S. GEOLOGICAL SURVEY}

Gordon P. Eaton, Director

Any use of trade, product, or firm names is for descriptive purposes only and does not imply endorsement by the U.S. Government.

For additional information write to:

\section{District Chief}

U.S. Geological Survey

1201 Pacific Avenue - Suite 600

Tacoma, Washington 98402
Copies of this report may be purchased from:

U.S. Geological Survey

Branch of Information Services

Box 25286, MS 517

Denver, Colorado 80225-0286 
CONTENTS

Abstract--.-

Introduction --

Purpose and scope --

Acknowledgments -

Description of study area--

Conceptual model -

Surface retention - - 7

Flow from hillslopes -

Horton overland flow -

Saturated overland flow -

Subsurface flow -

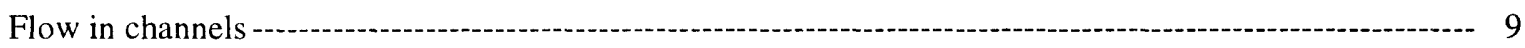

Interaction of surface water with ground water-

Generalizations about runoff in the study area -

Simulation of runoff -

Description of the numerical model

Impervious land segments--.-14

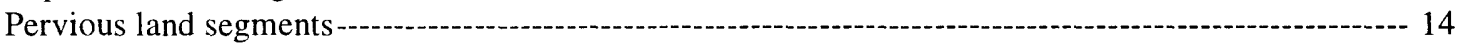

Channel network -

Construction of numerical basin models - -

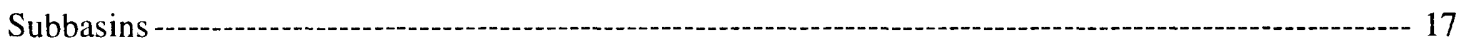

Land segments -

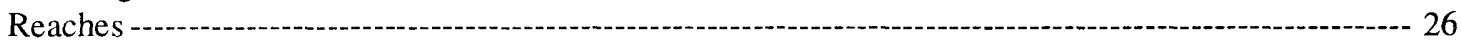

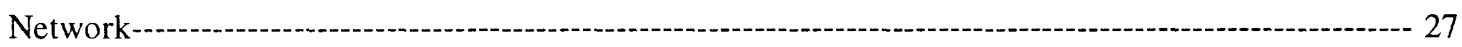

Calibration of the numerical model -

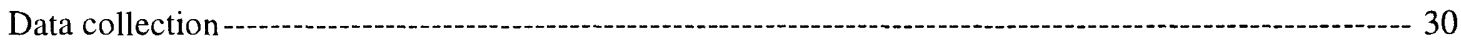

Catchment studies and the rural basin -

Basin calibration--

Results from runoff simulations--

Precipitation patterns ---

Comparison of simulated and observed runoff -

Annual and seasonal runoff -

Peak discharges and storm runoff volumes -

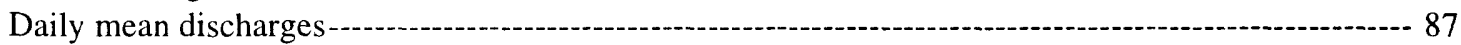

Sources of errors -

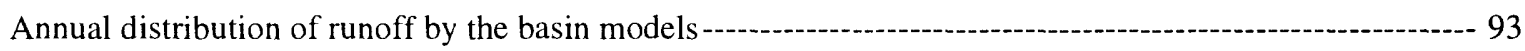

Long-term simulation -

Summary --

References cited -

Supplementary data - 


\section{FIGURES}

1. Map showing study area location, basin boundaries, and creeks in the study area in Pierce County, Wash.

2. Flowchart of simulated runoff from pervious land segments- 16

3. Map showing subbasin divisions, channel reaches, streamflow gages, and rain gages for the (a) Clear-Clarks Basin model and (b) Clover Creek Basin modet-......- 18

4. Map showing distribution of till, outwash, and saturated land segments in the study area in Pierce County, Wash.

5. Schematic diagram of the network design for the (a) Clear-Clarks Basin model and (b) Clover Creek Basin model--.-.-.-.- 28

6. Map showing the Cow Pasture Catchment, altitude contours, and the location of the soil-moisture sites, rain gage, and streamflow gage-- 37

7-8. Annual hydrograph showing:

7. Observed and simulated discharge at the Rural Basin, preliminary calibration model run, and rainfall recorded at the Canyon Road gage

8. Observed and simulated discharge at the Rural Basin, final calibration model run, and rainfall recorded at the Canyon Road gage

9. Storm hydrographs of observed discharge with the preliminary and final calibrated simulations for the Rural Basin and rainfall at the Canyon Road gage--... 42

10-15. Hydrographs showing:

10. Simulated soil moisture for the saturated land segment and observed available soil moisture at site T1.bot --- 44

11. Simulated soil moisture for the till-grass-flat land segment and observed available soil moisture

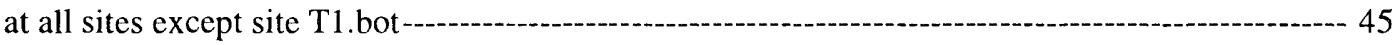

12. Simulated storm runoff and various components of flow from till-forest-flat and till-grass-flat land segments and rainfall from the Canyon Road gage---on 47

13. Simulated storm runoff and various components of flow from saturated and outwash-grass land segments and rainfall from the Canyon Road gage---o- 48

14. Simulated and observed discharge at Clear Creek at Pioneer Way for the preliminary and final calibration model runs and rainfall at the Canyon Road gage --- 52

15. Preliminary and final calibration model runs at Clear Creek at 100th Street East, observed and simulated discharge and channel losses for Clear Creek at Pioneer Way, and rainfall at the Canyon Road gage

16. Graphs showing monthly normal precipitation and monthly precipitation for water years $1990-92$ at McMillin Reservoir and observed monthly precipitation at the Canyon Road gago--.-.-.-.- 61

17-26. Annual hydrographs of observed and simulated daily mean discharge and daily rainfall:

17. For station 12090340 and for station 470948122211801

18. For station 12090355 and for station 470532122223901

19. For station 12090365 and for station 470948122211801

20. For station 12090380 and for station 470948122211801

21. For station 12090400 and for station 470948122211801

22. For station 12090500 and for station 470711122263201

23. For station 12102025 and for station 470948122211801

24. For station 12102140 and for station 471242122232201

25. For station 12102190 and for station 470948122211801

26. For station 12102212 and for station 471242122232201

27. Graphs showing observed and simulated annual runoff, seasonal runoff, storm runoff, and peak discharge data for all of the continuous-recording stream-gage sites in the study area----.----------- 75 


\section{FIGURES--Continued}

28-31. Hydrographs showing observed and simulated discharge and rainfall recorded at the Canyon Road gage for:

28. Swan Creek at 80th Street East and Swan Creek at Pioneer Way, for the January 5-10, 1990, storm -

29. Swan Creek at 80th Street East and Swan Creek at Pioneer Way, for the April 2-6, 1991, storm

30. Clover Creek at 25th Avenue East and Clover Creek near Tillicum, for the

February 18-21, 1991, storm

31. Clover Creek at 25th Avenue East and Clover Creek near Tillicum, for the

April 2-6, 1991, storm

\section{TABLES}

1. Definition of process-related Hydrological Simulation Program-FORTRAN (HSPF) parameters controlling the simulation of runoff from hillslopes in Pierce County, Wash--..- 13

2. Area of land segments as a percent of subbasins and area of subbasins, Pierce County, Wash----------- 20

3. Land segment groups used in runoff simulations and associated soil series found in the study area in Pierce County, Wash.-

4. Streamflow and rainfall gaging site names, locations, station numbers, and period of record, Pierce County, Wash.-

5. Results from two seepage runs on June 26, 1991, and April 21, 1992, showing gains and losses of water on the main stem of Clover Creek, Pierce County, Wash.-- 34

6. Calibrated process-related model parameters for each of the land segments, Pierce County, Wash----- 49

7. Monthly and annual precipitation, in inches, and the differences, in inches and percent, between precipitation recorded at the Canyon Road gage and at all other rain gages in the study area in Pierce County, Wash., for the water years 1990-92-

8. Observed and simulated annual and seasonal runoff data and differences between observed and simulated runoff at all continuous-recording stream-gaging stations in Pierce County, Wash.----------- 64

9. Observed and simulated storm runoff and peak discharge data for all continuous-recording stream-gaging stations in Pierce County, Wash.-- 78

10. Observed and simulated peak discharge data for all crest-stage stations, Pierce County, Wash---.------ 80

11. Mean error, bias, and standard error of estimate of simulated mean daily discharges at the continuous-recording stream-gaging stations, Pierce County, Wash.-

12. Simulated annual distribution of water, in inches, represented by precipitation recorded by the Canyon Road precipitation gage in the various flow paths and in storage for each of the land segments used in the models for water years 1990-92, Pierce County, Wash--

13. Simulated annual water balance, in inches, for the two basin models and selected individual basins for the 1991-92 water years, Pierce County, Wash.

14. Minimum and maximum simulated discharge for the continuous-recording streamflow sites and minimum and maximum simulated volumes for the ground-water reservoir for two periods of simulations for the Clear-Clarks and Clover Basin models, Pierce County, Wash--------.-----------. 98

15. Input sequence of the Clear-Clarks Basin model used to run Hydrological Simulation Program-FORTRAN (HSPF)

16. Input sequence of the Clover Creek Basin model used to run Hydrological Simulation Program-FORTRAN (HSPF) 


\section{CONVERSION FACTORS AND VERTICAL DATUM}

\begin{tabular}{rll}
\hline Multiply & By & To obtain \\
\hline inch (in) & 2.54 & centimeter \\
inches per hour (in/hr) & 2.54 & centimeter per hour \\
inches per day (in/d) & 2.54 & centimeter per day \\
foot $(\mathrm{ft})$ & 0.3048 & meter \\
feet per hour $(\mathrm{ft} / \mathrm{hr})$ & 0.3048 & meter per hour \\
acre & 0.4047 & hectacre \\
acre-foot $(\mathrm{acre}-\mathrm{ft})$ & $1,233.5$ & cubic meter \\
cubic foot per second $\left(\mathrm{ft}{ }^{3} / \mathrm{s}\right)$ & 0.02832 & cubic meter per second \\
mile $(\mathrm{mi})_{\text {square mile }\left(\mathrm{mi}^{2}\right)}^{1.609}$ & 2.59 & kilometer \\
& & square kilometer
\end{tabular}

Temperature: To correct temperature given in this report in degrees Fahrenheit $\left({ }^{\circ} \mathrm{F}\right)$ to degrees Celsius $\left({ }^{\circ} \mathrm{C}\right)$, use the following equation: ${ }^{\circ} \mathrm{C}=5 / 9\left({ }^{\circ} \mathrm{F}-32\right)$

Sea Level: In this report "sea level" refers to the National Geodetic Vertical Datum of 1929 (NGVD of 1929)--a geodetic datum derived from a general adjustment of the first-order level nets of both the United States and Canada, formerly called Sea Level Datum of 1929.

Altitude: In this report "altitude" is measured in feet above or below sea level. 


\title{
SURFACE-WATER HYDROLOGY AND RUNOFF SIMULATIONS FOR THREE BASINS IN PIERCE COUNTY, WASHINGTON
}

\author{
By M.C. Mastin
}

\begin{abstract}
The surface-water hydrology in Clear, Clarks, and Clover Creek Basins in central Pierce County, Washington, is described with a conceptual model of the runoff processes and then simulated with the Hydrological Simulation Program-FORTRAN (HSPF), a continuous, deterministic hydrologic model. The study area is currently undergoing a rapid conversion of rural, undeveloped land to urban and suburban land that often changes the flow characteristics of the streams that drain these lands. The complex interactions of land cover, climate, soils, topography, channel characteristics, and groundwater flow patterns determine the surface-water hydrology of the study area and require a complex numerical model to assess the impact of urbanization on streamflows. The U.S. Geological Survey completed this investigation in cooperation with the Storm Drainage and Surface Water Management Utility within the Pierce County Department of Public Works to describe the important rainfall-runoff processes within the study area and to develop a simulation model to be used as a tool to predict changes in runoff characteristics resulting from changes in land use.
\end{abstract}

The conceptual model, a qualitative representation of the study basins, links the physical characteristics to the runoff process of the study basins. The model incorporates 11 generalizations identified by the investigation, eight of which describe runoff from hillslopes, and three that account for the effects of channel characteristics and ground-water flow patterns on runoff.

Stream discharge was measured at 28 sites and precipitation was measured at six sites for 3 years in two overlapping phases during the period of October 1989 through September 1992 to calibrate and validate the simulation model. Comparison of rainfall data from October 1989 through September 1992 shows the data-collection period beginning with 2 wet water years followed by the relatively dry 1992 water year.
Runoff was simulated with two basin models-the Clover Creek Basin model and the Clear-Clarks Basin model-by incorporating the generalizations of the conceptual model into the construction of two HSPF numerical models. Initially, the process-related parameters for runoff from glacial-till hillslopes were calibrated with numerical models for three catchment sites and one headwater basin where streamflows were continuously measured and little or no influence from ground water, channel storage, or channel losses affected runoff. At one of the catchments soil moisture was monitored and compared with simulated soil moisture. The values for these parameters were used in the basin models. Basin models were calibrated to the first year of observed streamflow data by adjusting other parameters in the numerical model that simulated channel losses, simulated channel storage in a few of the reaches in the headwaters and in the floodplain of the main stem of Clover Creek, and simulated volume and outflow of the ground-water reservoir representing the regional ground-water aquifers. The models were run for a second year without any adjustments, and simulated results were compared with observed results as a measure of validation of the models.

The investigation showed the importance of defining the ground-water flow boundaries and demonstrated a simple method of simulating the influence of the regional ground-water aquifer on streamflows. In the Clover Creek Basin model, ground-water flow boundaries were used to define subbasins containing mostly glacial outwash soils and not containing any surface drainage channels. In the Clear-Clarks Basin model, ground-water flow boundaries outlined a recharge area outside the surface-water boundaries of the basin that was incorporated into the model in order to provide sufficient water to balance simulated ground-water outflows to the creeks. A simulated ground-water reservoir used to represent regional ground-water flow processes successfully provided the proper water balance of inflows and outflows to the major ground-water discharge locations, but its simple design 
did not always accurately simulate the correct storm hydrograph shape at two Clover Creek sites where most of the storm-water discharge is ground water.

Results indicate that the models accurately simulate the important runoff processes in the study area and therefore confirm the validity of the conceptual model. Observed and simulated streamflows were compared for all the stream gaging stations. For the second year of comparisons, the validation period, the largest difference between simulated annual runoff and observed annual runoff was 2.72 inches or 25.7 percent for one of the catchment sites, and the differences for the remainder of sites ranged from -12.0 to 15.8 percent. Percentage differences for winter and spring runoff range from -28.9 to 42.2 percent. Percentage differences for summer runoff are the highest, although actual differences are low; the highest percentage difference is 700 percent, representing an actual difference of only $0.07 \mathrm{inch}$. Two thirds of the percentage differences between simulated and observed peak flows for the three largest peaks of the water year at each station were less than 27 percent. Percentage differences between simulated and observed storm runoff volumes for the three largest storms at the continuous-recording streamflow stations ranged from -22.9 to 84.6 percent, with two-thirds of the differences being less than 19 percent. Percentage differences between simulated and observed daily mean discharges had absolute errors ranging from 8.6 to 197.7 percent. Long-term simulations of 30 and 31 years confirmed the stability of the models by not simulating unreasonable ranges of volumes in the simulated ground-water reservoirs or unreasonable peak streamflows.

\section{INTRODUCTION}

Pierce County, Wash., is currently undergoing a rapid conversion of rural, undeveloped land to urban and suburban landscapes. Land-use changes may cause changes in the surface hydrology that have a dramatic impact on the flow characteristics of the streams that drain the watershed. The hydrologic effects of urbanization have been well documented (Savini and Kammerer, 1961; Seaburn, 1969; Anderson, 1970). Increasing urbanization increases the amount of impervious surfaces and reduces infiltration of precipitation into the soil. Reduced infiltration results in increases in the quantity of runoff to the streams. These changes often result in problems such as increased flooding, erosion, and sedimentation.
Therefore, effective land development planning requires consideration of the effects of land-use changes on streamflows in the basin where development is occurring. Pierce County recently formed a Surface Water Management Utility to plan for and alleviate the impact of land-use changes on streams. The U.S. Geological Survey, (USGS) in cooperation with the Surface Water Management Utility, conducted an investigation of the rainfall- runoff processes important to streamflow generation in Pierce County and developed a method to predict changes in runoff characteristics resulting from changes in land use.

This investigation involved proposing a conceptual model of how the physical characteristics of a basin affect runoff and then applying a numerical model to simulate streamflows according to guidelines provided by the conceptual model. The surface-water hydrology of a watershed was defined by the combination of physical properties found within it, including the geology, soils, vegetation, topography, drainage patterns, land use, and climate, and then the conceptual model linked these basin properties with runoff processes that generate streamflow. A typical drainage basin found in Pierce County is a complicated mosaic of basin properties all contributing in various degrees to the generation of streamflow. In order to understand the cumulative effect of all of these contributing areas within the basin, a numerical model of the basin as a system of storages, inputs, and outputs is employed. Precipitation and potential evapotranspiration (PET) are supplied to the model as input. User-defined inputs to the model define the size of the different storages, the rate of flow in and out of storage, and the network of linkages that are designed to simulate water movement through the basin according to the hydrological processes defined in the conceptual model. Success of the simulation is measured by comparison of observed and simulated streamflows. Once an accurate simulated model of runoff is created for a basin, the effects of changing land use on the runoff characteristics of a stream in the basin can be shown.

The Hydrological Simulation Program-FORTRAN (HSPF; U.S. Environmental Protection Agency, 1984) was the numerical model chosen for the simulation of runoff in Pierce County because recent studies in nearby King and Snohomish Counties (Dinicola, 1990) and in Thurston County, located just south of Pierce County (Berris, 1995), demonstrated this model to be successful in simulating runoff in similar landscapes. This study uses much of the same conceptual model of runoff processes and guidelines in the construction of the numerical model as the two studies mentioned above. However, it does add some refine- 
ment to the conceptual model and the calibration process as well as provide calibrated numerical models for three basins in Pierce County: Clear, Clarks, and Clover Creeks.

Runoff was simulated for the three basins by constructing and calibrating HSPF numerical models of basin hydrology. Because little or no streamflow data existed for the streams, a network of 28 stream-gaging sites was constructed to collect 2 years of streamflow data for calibration and validation of the models. Precipitation data were collected at six sites and were used as input to the models. The model parameters and linkages that control the simulated movement of water through the system were adjusted as necessary through a calibration procedure that compared observed streamflow with simulated streamflow. Graphical and statistical comparisons of observed streamflows and simulated streamflows provided a measure of the accuracy of the models. (The reader may note that the singular "model" or plural "models" may be used, depending on whether the discussion is about the framework of the HSPF modeling system [singular use] or about the specific, parameterized representations of individual basins [plural use]. The meaning and usage will be clear from the context.)

The time and budget constraints of this investigation allowed streamflow data for calibration and validation of the numerical models to be collected for only 2 years. Generally, it is suggested that preferably 5 years or more of observed data be available for calibration (Linsley, Kohler, and Paulhus, 1982, p. 347). The network of stream and precipitation gages used in this investigation was left in place to allow continued monitoring by staff of the Pierce County Storm Drainage and Surface Water Management Utility. At a later date when more observed streamflow information is available, the simulated streamflow generated from the models presented in this investigation can be compared with a longer observed record to more accurately define the confidence level of the accuracy of the models or refine model parameters.

\section{Purpose and Scope}

This report (1) describes the conceptual model of the relations between the important runoff processes affecting the surface-water hydrology and the physical properties in Clear, Clarks, and Clover Creek Basins; (2) explains the construction and application of a deterministic, numerical model to simulate runoff in the basins; and (3) discusses the success of the simulations to represent observed runoff. The objective of simulating streamflows with a numerical model for these basins is to provide a tool for planners and engineers to assess the impacts to streamflows due to possible land-development scenarios.

Observed streamflow, soil moisture, and precipitation data were collected to provide input to the numerical model and to compare with simulated data. Twenty-eight streamflow-gaging stations and six precipitation data sites were constructed and monitored during two overlapping phases of operation during the period of October 1989 to September 1992. During this period, several large storms with high precipitation totals occurred, and 1 relatively dry water year (1992) was recorded. Phase I included the operation of the gaging network for Clear and Clarks Creeks for the period October 1989 to September 1991, and Phase II included the operation of the gaging network for Clover Creek for the period October 1990 to September 1992. Calibration of the model involved comparing the first year of observed streamflow with simulated streamflow. The second year of observed streamflow data was compared with the calibrated model simulations to test the validity of the models. Soil-moisture data were collected during the period from February 1991 to May 1992 at seven sites and from July 1991 through September 1993 at an eighth site on a cow pasture catchment within the Clover Creek Basin. The soil-moisture data augmented the streamflow data by providing a measure of how well the numerical models could simulate the soil-moisture processes in the study area. Precipitation was measured at six sites within the study area, and the data were used as input to the numerical models.

One separate numerical model for Clear and Clarks Creek, one model for Clover Creek, and three models of catchments (drainage areas less than 200 acres) in Clover Creek, each having different land uses, were calibrated and validated for the periods when streamflows were measured. In the calibration process, streamflow and soilmoisture data collected at the catchment studies assisted in defining the runoff parameters for different land types in the study area. These parameters were used in all of the basin numerical models, which were calibrated individually to observed streamflow data in each of the basins. The closeness of the simulated to observed runoff provided a test of the validity of the conceptual model as represented by a numerical model.

Long-term (30 and 31 years) model runs were made for each of the models. The range in simulated runoff rates and simulated volumes in the ground-water storage was recorded to assess how stable the results were and how well the data collection period represented long-term hydrologic condition. 


\section{Acknowledgments}

The author extends appreciation to the Pierce County Storm Drainage and Surface Water Management Utility for its assistance in collecting streamflow data and providing much of the available mapping data. The author also wishes to acknowledge the citizens of Pierce County who allowed access on their property to install and maintain gages and those who diligently collected gage heights on a daily basis.

\section{DESCRIPTION OF THE STUDY AREA}

The three drainage basins that define the study area all share common boundaries and are located in central Pierce County, Wash., at the southeastern end of the Puget Sound Lowland region (fig. 1). The Clear Creek drainage basin has two separate creeks, Swan Creek and Clear Creek, with a combined drainage area of 6.53 square miles. The Clarks Creek Basin has three separate creeks, Canyon Creek, West Fork Clarks Creek (also referred to as Rody Creek), and Diru Creek, with a combined drainage area of 4.51 square miles. The Clover Creek drainage basin contains several creeks that all drain into Clover Creek, with a combined drainage area of 75.9 square miles. The major streams in the Clover Creek Basin besides Clover Creek include Spanaway Creek, Morey Creek (a distributary from Spanaway Creek), and the North Fork of Clover Creek. Spanaway Lake on Spanaway Creek, which contains about 4,600 acre-feet, is the only large lake in the study area.

Warm, dry summers and cool, wet winters characterize the climate of the study area. The mean monthly January temperature for the period $1951-80$ was $37^{\circ} \mathrm{F}$ at McMillin Reservoir, a long-term weather station located 2 miles east of the study area. The mean monthly temperature for July and August, the two warmest months, is $63^{\circ} \mathrm{F}$. The mean annual precipitation is 41.40 inches, and 78 percent of the precipitation falls from October through April (U.S. Department of Commerce, 1982). Typical rain storms of the region arrive from the west or southwest as large frontal storms of low intensity and long duration. Snow falls rarely and does not contribute substantially to the total annual precipitation, so snowfall was not considered in the description of the runoff processes or addressed in the runoff simulations in this study.
The study basins have complex sets of physical features that overlay each other. These features include changing topography, varied distribution of soils, and a non-uniform pattern of land cover resulting from the land use and settlement patterns of the region. The result is that a large number of land types, each having a unique runoff response to rainfall, are distributed throughout the basins.

The topography and soil distribution of the study area can best be described in the framework of the surficial geology. The surficial materials consist entirely of unconsolidated deposits, which cover all of the study area.

These deposits were formed by an ice sheet that extended southward into Puget Sound (the Puget Lobe) during the last period of continental glaciation known as the Vashon Stade, which occurred during late Pleistocene time approximately 15,000 years ago. The stratigraphic units of glacial deposits resulting from this glacial advance and retreat are known as the Vashon Drift (Crandell and others, 1965). Two landforms relating to the Vashon Drift that contrast greatly in their hydrologic response to rainfall dominate large parts of the study area: (1) rolling hills of glacial till and (2) level plains of glacial outwash.

Deposits of glacial till make up the principal land types in the northeast part of the study area, which includes the Clear Creek and Clarks Creek Basins and the North Fork of Clover Creek Basin. Lodgement till consists of deposits up to 200 feet thick compacted under the weight of the glacier. Because of its compact character, it is frequently referred to as hardpan. Ablation till, which was formed when the ice melted and left behind sediment carried by the ice, is found on top of the lodgement till and varies in thickness from zero to several feet. Ablation till consists of loose, unstratified sand and gravel that is well drained, in contrast to the lodgement till, which has low permeability. Lodgement till restricts infiltration of water and can create saturated soil conditions for varying lengths of time during winter and spring. Soils that formed on these areas are grouped in the soil association known as Kapowsin (U.S. Department of Agriculture, 1979). The topography varies from terrain in the headwaters area that is relatively flat but contains some rolling hills impounding numerous small lakes and swampy depressions, to terrain near the mouths of streams cut into steep-sloped canyons. Altitude ranges from a high of 500 feet in the headwaters of West Fork Clarks Creek to 20 to 30 feet at the northern boundary of the study area where the five creeks in the Clear and Clarks Creek drainages flow into the Puyallup River Valley at five separate locations along Pioneer Way. 
In the southern and western portion of the study area, the landforms and their hydrologic characteristics are dominated by a glacial outwash deposit known as the Steilacoom Gravels. This outwash deposit has consistently coarse gravels, generally 20 feet thick or less. It is believed to have been formed during the release of water from Lake Puyallup, a Pleistocene glacial lake, during the retreat of the glacier (Walters and Kimmel, 1968). The soil is so well drained that in undeveloped areas there are no surface-water drainage channels other than the two main creeks, the main stem of Clover Creek and Spanaway Creek, which both emerge from springs. Soils that formed over the Steilacoom Gravels are identified with the group classified as the Spanaway Soil association (U.S. Department of Agriculture, 1979). The Steilacoom Gravels form a large flat plain containing several small lakes and one large lake, Spanaway Lake. The plain extends to the southeast, where it merges with a hilly region formed by glacial till deposits. The highest altitudes in the study area are found in these hills at 860 feet. The plain extends to the northwest beyond the study area boundaries, which end at the mouth of Clover Creek, at the point it enters Steilacoom Lake at an altitude of 206 feet.

Other surficial deposits in the study area include pockets of peat soils formed in depressions where the soil remains saturated most of the year. Along the deep canyons near the mouths of Swan, Clear, West Fork Clarks, Canyon and Diru Creeks, there are some exposures of the Salmon Springs Drift, a glacial deposit older than the Vashon Drift. At the contact of the Salmon Springs Drift and the overlying, highly permeable Vashon advance gravel deposits, many springs are found because the low permeability of the Salmon Springs Drift restricts downward movement of water. Pockets of recessional outwash deposits laid down by meltwater from the receding Puget Lobe are scattered throughout the study area. They have high infiltration rates similar to the Steilacoom gravels. Pockets of advance gravel deposits are scattered in a similar manner as the recessional outwash deposits in the study area. These gravels, deposited during the Vashon Stade in front of the advancing glacier, are generally more compact than recessional gravels.

Land cover is mostly a function of the degree of urbanization. Land cover in undisturbed areas of the study basins is evergreen forest or mixed deciduous-evergreen forest. The typical progression of land cover for the study area begins with a forest cover, changes to a grass-pastured land cover as rural homeowners move into an area, and then continues to the highly impervious land cover of the urbanized landscape as population densities increase. Approximately 30 percent of the study area is covered by forest. The more common land cover is a random patchwork of grass pastures and lawns associated with a rural landscape of privately owned small to large acreages. Approximately 43 percent of the study area consists of residential areas of housing densities of less than or equal to one unit per acre. In general, the rural landscape becomes more urbanized the closer it is to Tacoma and the Interstate Five corridor. Urbanization is especially evident in the lower Clover Creek drainage, where the communities of Parkland, Spanaway, and Lakewood are situated near the section of the study area crossed by Interstate Five. These communities are much more urban in character than the rest of the study area. An exception to the generalization about urbanization close to Tacoma is the lower Swan Creek watershed, which lies close to downtown Tacoma but is sparsely populated because most of the area consists of a county park and a series of large gravel pits. Approximately 19 percent of the study area is commercial, industrial, or high-density residential (four or more units per acre) land use. Urban areas contain a higher percentage of paved surfaces and roof tops than rural areas, and thus they contain a higher percentage of area impervious to rainfall, resulting in a higher percentage of surface runoff. Just south of Interstate Five, Clover Creek passes through an area of mostly paved roads and runways that makes up McChord Air Force Base, and further to the south, upper Spanaway Creek lies in a relatively undisturbed landscape that is part of the Fort Lewis Military Reservation. 


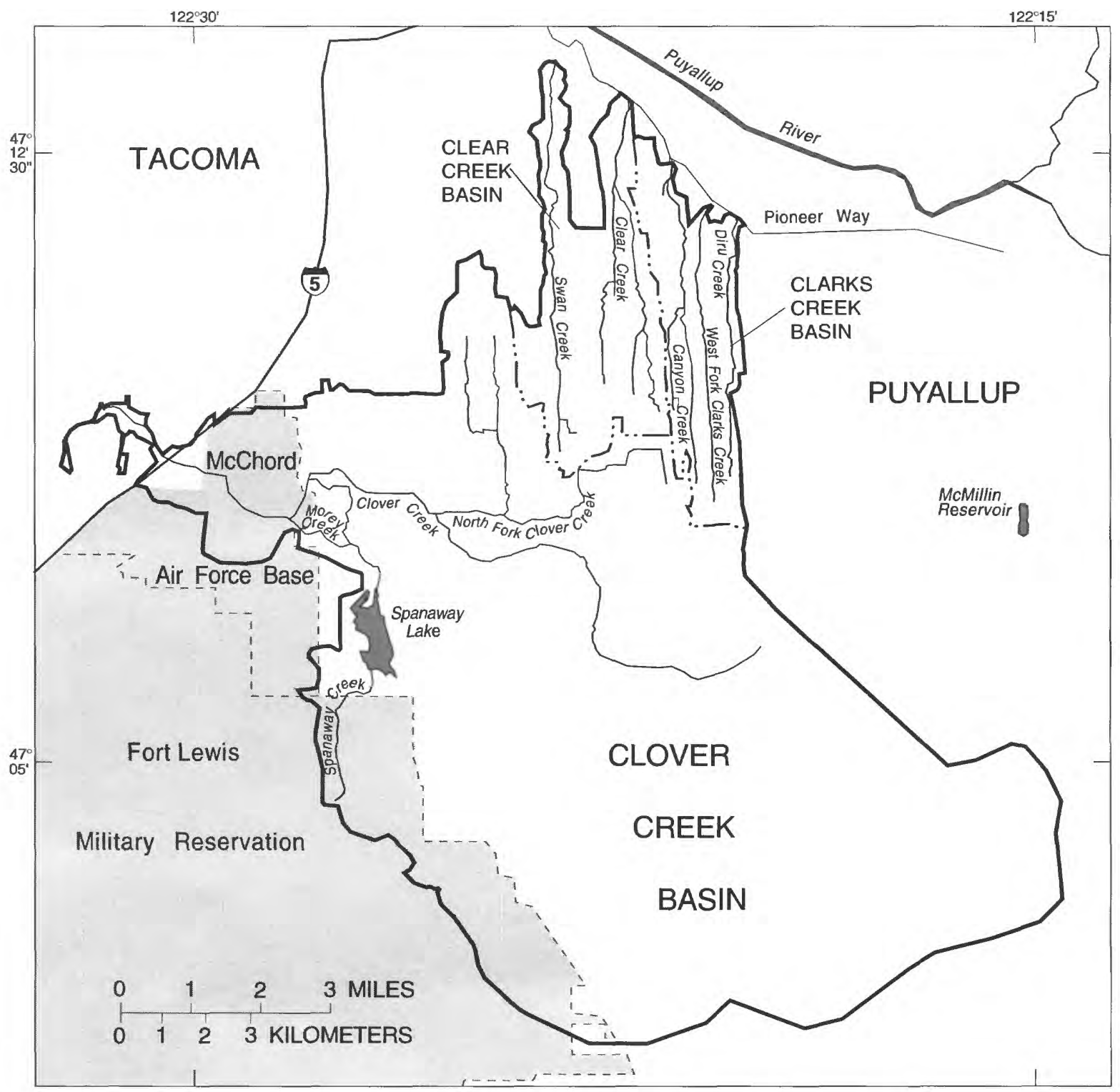

EXPLANATION

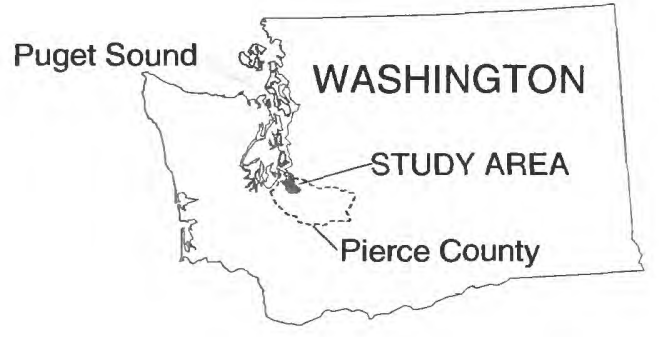

Figure 1.--Study area location, basin boundaries, and creeks in the study area in Pierce County, Washington. 


\section{CONCEPTUAL MODEL}

The conceptual model defines the important hydrologic processes that describe the pathways, fluxes, and storages of water within the study area. The processes are those of the runoff cycle, which includes that portion of the hydrologic cycle beginning with (1) surface retention of rainfall at the land surface, continuing with (2) flow from hillslopes to the stream channels, and then ending with (3) flow in the channels toward the mouths of the streams; the runoff cycle also considers (4) the interaction of surface water with ground water.

Because the physical attributes of the study basins affect runoff processes, the model describes the characteristic land types identified in the study area with one or more runoff processes. In doing so, the conceptual model provides a basis for understanding how changes in the physical character of the landscape can create changes in the runoff characteristics of the streams.

In describing the principal runoff processes in the study area, the conceptual model provides an understanding of the mechanics of the various runoff processes, an understanding that is a vital aid in developing a hydrologically correct numerical simulation of runoff. Generally, a numerical model contains a large set of parameters that determine how the model represents the runoff process. These parameters are adjusted during the calibration process to fit simulated data generated by the model to corresponding observed data. The large set of parameters provides many degrees of freedom to the user to arrive at similar simulations with an almost infinite number of combinations of parameters. Therefore, it is important to constrain the range of values for the parameters to values that are consistent with the physical runoff processes defined in the conceptual model. Assuming that the correct runoff processes have been identified within the conceptual model and that the parameters used in the numerical model allow reasonably accurate simulation of the processes, the numerical model will be hydrologically realistic. This model will more accurately predict changes in runoff with changes in land use or runoff in other basins with similar physical attributes than a model calibrated without proper consideration of how runoff was generated.

\section{Surface Retention}

When rain falls, it falls either on leaves or branches of vegetation or on the land surface. Water stored on the wetted surfaces of vegetation is called interception storage. Water stored on the land surface is termed depression storage, and together with the interception storage, the quantity of rain retained from entering the soil or flowing overland is surface retention.

The quantity of interception storage depends on vegetation type, density, form, and age. When the storage capacity of vegetation has been exceeded, water drips off branches and leaves, as throughfall or stemflow, to the ground, where it is available to enter the soil or to flow overland. Water is removed from interception storage only through evaporation. In non-vegetated areas, small depressions on the surface store water called depression storage. When depression storage has been exceeded, water flows downslope as overland flow. As with interception storage, water is removed from depression storage only through evaporation. The small quantities of storage available in surface retention make the storage effects of surface retention unimportant in major runoff events, but it often influences a sizable portion of annual rainfall and may be important in reducing total annual runoff.

In the study area, vegetation in undisturbed areas is composed of dense conifer or mixed conifer and deciduous forests. The large mass of leaves and branches of these forests provides a relatively high interception capacity. Reported quantities of interception vary with different observers. From a number of studies, Dunne and Leopold $(1978$, p. 88$)$ computed median values of canopy interception of rain as a percentage of gross rainfall to be 13 percent for deciduous forests and 22 percent for coniferous forests. They also reported that total annual interception by grasses is generally not reported but is usually less than interception in forests. In disturbed areas of the study area, many of the trees have been removed, and in some areas, they have been replaced by grass. The result is a decrease in the quantity of moisture stored as interception storage and transpired from the deep rooting zone of the soil. Depression storage as puddles may be important in these areas where interception is absent. 


\section{Flow From Hillslopes}

The conceptual model includes three processes of runoff from hillslopes that produce most of the runoff from the several major land types in the study area. They include two processes for overland flow: Horton overland flow and saturated overland flow. The other process, subsurface flow, has flow pathways underground. The relative importance of these processes is determined by characteristics of the land types, such as rates of infiltration. Defining the flow processes involves describing (1) the flow path runoff takes from the land unit to the stream channel, (2) the rate of flow to the stream channel, and (3) the mechanics of the process involved in generating runoff.

\section{Horton Overland Flow}

When the rainfall rate exceeds the infiltration capacity (the maximum rate at which water can enter the soil) of the soil, Horton overland flow occurs. This is a common occurrence in urban areas during a rainstorm. Pavement, rooftops, and compacted surfaces have little or no infiltration capacity, and overland flow is readily generated. In rural areas of the study area, the conversion of forest lands to pastures and lawns has modified the natural soil structure and texture and has generally reduced infiltration capacities of the soils. Nearby impervious areas often drain into these modified soils, and the increased rate of water input increases the likelihood of overland flow. Rain gutters that drain impervious roofs onto lawns provide an example. During medium to heavy rainfall intensities, these pasture and lawn areas are likely to produce Horton overland flow.

Velocities of overland flow are relatively high compared to subsurface flow, ranging from 30 to 1,600 feet per hour (Dunne and Leopold, 1978), and are controlled by the resistance to flow on the overland flow plane and the slope of the plane. Storm discharge hydrographs dominated by this type of runoff are characterized by steep rising and recessional limbs before and after the peak and a relatively short lag time from peak rainfall intensity to peak stream discharge.

Undisturbed forest soils of the Puget Sound Lowland have infiltration rates from 10 to 50 inches per hour (Burges and others, 1989). These are well above the rates of rainfall for the study area, which is estimated to be about 0.75 inch per hour for the 100-year, 1-hour rate
(U.S. Department of Commerce, 1973). (The 100-year, 1-hour rate is the average rate of rainfall over a 1-hour period that is exceeded on average only once every 100 years.) Thus Horton overland flow is rare in undisturbed soils except under saturated soil conditions, conditions which are associated with a separate runoff process known as saturated overland flow.

\section{Saturated Overland Flow}

Once a soil becomes saturated, the infiltration capacity is zero, and any additional rain will become overland flow. Saturated overland flow occurs at the base of slopes along drainage channels in poorly drained depressions (wetlands) and at topographic hollows where flow lines converge. In contrast to Horton overland flow, the soils are saturated from the bottom up because of rising water tables fed from direct precipitation, shallow subsurface flow, or ground-water flow. The runoff response to rainfall is quick once the soil becomes saturated, the same as described above for Horton overland flow. Typically, in the fall at the beginning of the rainy season, the groundwater table has dropped below land surface, and little runoff is generated from the first rain storms. As the rainy season progresses and the water table rises, the saturated overland flow process becomes dominant in these areas and generates rapid runoff responses to rainfall. In the glacial-till soils of the study area, lodgement till impedes downward flow of water and creates perched water that saturates the thin overlying soil layer. Flat terrain common to much of the study area enhances the saturated conditions because lateral drainage of the perched water is slow. Saturated overland flow may be the dominant flow process during storms in mid-winter through spring.

\section{Subsurface Flow}

Subsurface flow-often referred to as interflowoccurs when rainwater infiltrates into the soil and moves laterally in the shallow subsurface of the soil horizon. This flow process is believed to be dominant in the glacial till soils of the study area. The Soil Conservation Service (U.S. Department of Agriculture, 1979) lists the permeability (the rate that water moves through soil) for the lodgement till as less than 0.06 inch per hour and for typical soil above the lodgement till as from 0.6 to 2.0 inches per hour. Downward moving water encounters the relatively impervious lodgement till and moves laterally downslope towards the stream channel. 
In glacial till basins of the study area, the subsurface flow process occurs in combination with saturated overland flow and results in variable rates of runoff from hillslopes. Lateral flow rates through the soil matrix increase as the slope increases, but even the fastest rates are much slower than overland flow rates. However, the subsurface water may return to the surface (return flow) at locations where interflow streamlines meet, such as topographic hollows, or at areas where the water table has intersected the surface. Dunne and Black (1970) measured return flow velocities that were 100 to 500 times greater than the velocity of subsurface flow in glacial-till catchments in Vermont. When subsurface flow is dominant, the characteristic response of runoff to rainfall is slower than the overland flow response. The shape of the discharge hydrograph is more attenuated, and the lag time between peak rainfall rate and peak discharge rate is greater. Between storm flows, discharge will be greater than an area characterized by overland flow as slow moving water from distant parts of the watershed arrives at the channel days or weeks after falling on the ground.

One of the early conceptual models of storm-water runoff from hillslopes in humid climates introduced the variable-source concept (Hewlett and Hibbert, 1967). The concept states that areas of runoff generation (source areas) vary in size both seasonally and during storms. A watershed is dynamic, and the size of source areas for storm runoff depends on soil properties, antecedent moisture conditions, and storm intensity and duration. Therefore, rainstorms of similar volumes may generate varying peak discharges and storm runoff volumes from a given watershed. The importance of the variable-source concept as an underlying theme that ties the runoff processessubsurface, return and saturated overland flow-to the dynamic nature of runoff from watersheds in humid climates has been expressed by several authors (Pierce, Stewart, and Sklash, 1986; and Dunne and Leopold, 1978). The concept provides a basis for understanding the generation of storm runoff from glacial till land types found within the study area. It also underscores the importance of defining the soil properties of a particular land type, accounting for antecedent moisture conditions in the watershed, and knowing the intensity and duration of storms.

\section{Flow in Channels}

Once water enters the channel, channel roughness, geometry, and slope influence the delivery of water to downstream locations. In the headwaters of the till basins of the study area, channels have gentle slopes, and in some locations large wetlands provide considerable water storage. Both factors tend to attenuate flood peaks downstream. Channels in the Clear and Clarks Creek drainages enter canyons as they approach the Puyallup Valley, where steep slopes and little storage capacity result in increased streamflow velocities and quicker runoff response to rainstorms. In contrast, Spanaway Creek and the main stem of Clover Creek have gentle slopes and wide stream valleys as they flow through the Steilacoom outwash plains. On these streams, overbank storage of floodwaters in the wide valley plains reduces flood peaks.

Observation of streamflows in the study area indicated that the conceptual model needed to account for channel losses of water by infiltration through permeable stream beds. In many of the streams it is common to observe flowing streams in the upper reaches, dry channels in sections further downstream, and full flowing streams near the mouths. Losses are believed to be a large percentage of total flow, even during storm runoff, on many of the streams.

Channel losses are common at the head of the canyon sections of streams in the Clear and Clarks Creek Basins where the streambed cuts below the till hardpan and encounters a permeable substratum. Large water losses begin in the main stem of Clover Creek where the channel diverges into two channels in a large wetland section about halfway on the total length of the channel. Low banks in this area allow water to spread over large areas and thereby allow larger volumes to infiltrate into the soil. Farther downstream, the channels converge, but channel losses are still large. Local residents have said that these losses are due to breaks in the "seal" (believed to be fine-grained deposits) of the channel bed where tree stumps were removed from the natural channel bed. It was also reported by residents that in the section of channel on the main stem of Clover Creek below the confluence of the North Fork of Clover Creek, where the channel bed is paved, holes were intentionally punched through a part of the paved channel to promote channel losses (oral communication with Paul Russel, a long-time resident on Clover Creek, April 1992). 


\section{Interaction of Surface Water with Ground Water}

Ground water contributes runoff into a stream channel directly or indirectly from seeps and springs, and it is most significant in the glacial outwash deposits of the study area. In glacial outwash deposits of the study area, permeable soils are underlain by more permeable glacial outwash deposits. The Spanaway soil association, the most common glacial outwash soil of the study area, is reported to have a permeability from 2.0 to 6.0 inches per hour at a depth below 18 inches (U.S. Department of Agriculture, 1979). Most, if not all, of the rain that falls on these soils will percolate vertically through the soil matrix to become recharge to the aquifer.

Runoff from undisturbed glacial outwash land types will be almost entirely ground-water discharge, and the response to rainfall will be slow. Flow rates of ground water are proportional to the slope of the water table, which often mimics the slope of the land surface. The slope of the land surface of the outwash deposits is generally mild in the study area, and therefore the slope of the water table is generally mild and flow rates are slow. The lag time between rainfall peaks and stream discharge peaks may be on the order of days or weeks, resulting in storm-discharge hydrographs that are greatly attenuated because a large percentage of the incident precipitation is routed to ground water.

Because of high infiltration rates in the large areas of glacial outwash, surface water interacts substantially with ground water in the study area. The detailed ground-water study that would be necessary to define the precise movement of ground water in the study area is outside the scope of this project. However, reports by Walters and Kimmel (1968) and by Brown and Caldwell (1985) provide detailed accounts of geohydrology of the area and generalized maps of ground-water flow paths.

Many springs have been observed in the lower canyon sections in the Clear and Clarks Creek Basins of the study area. Many flow all year, long after streams in the upper portion of the basin have gone dry. The main stem of Clover Creek originates from springs and contains sections of stream channel where large increases in streamflow can be measured during all seasons of the year and no surface tributary channels exist. These are all examples of ground-water discharge sites that have been identified in the study area, and at some locations the volume of ground-water discharge has been measured. The source area of ground-water recharge or the pathway it has taken to get to these discharge sites can be inferred from generalized ground-water flow maps, but precise locations are not known.

The conceptual model of the interaction of surface water and ground water takes recharge from the hillslopes and water from channel losses and adds it to an unconfined regional aquifer that acts as a large reservoir. Water from the regional aquifer supplies the stream channel with a relatively constant discharge at locations where springs and seeps are present or where the water table intersects the channel. The areal extent of the regional aquifer is not controlled by the surface watershed boundaries of the study basins, and the quantity of recharge from a particular basin does not have to balance the quantity of discharge from the aquifer into the same basin.

\section{Generalizations About Runoff in the Study Area}

Eleven generalizations summarize the conceptual model. The first seven generalizations discuss surface retention and runoff from hillslopes in the study area. With only minor alterations, they are the same as those discussed by Dinicola (1990) for similar basins in the Puget Sound Lowland in King and Snohomish Counties. The remaining four generalizations are about supplemental influences on the hydrology of the study area.

(1) Retention storage and plant transpiration are decreased when land is disturbed.

(2) Rapid, direct overland flow is the runoff process on impervious areas.

(3) Horton overland flow, in combination with some of the other flow processes, is an important runoff process from disturbed pervious land areas. The importance of Horton overland flow in disturbed pervious land areas is due primarily to changes in soil structure and texture brought about by disturbing the land that reduces infiltration and to increased moisture supply from nearby impervious surfaces.

(4) Horton overland flow is not an important runoff process over most, if not all, of the undisturbed lands of the study area. 
5) Saturation overland flow is an important runoff process in depressions, stream bottoms, and flat till-capped hilltops. Runoff response to rainfall is quick but only after the initial rain storms have filled the available water capacity of the soils.

(6) Subsurface flow combined with return flow and saturated overland flow is the predominant flow process on undisturbed hillslopes mantled with glacial till. Within the soil profile, transmission of water is greatly retarded, but once the water returns to the surface, it can contribute substantially to storm runoff. The rate of subsurface flow is proportional to the angle of the hillslope.

(7) Ground-water flow is the predominant runoff process on glacial outwash deposits. Runoff rates from this process are relatively slow and attenuated.

(8) Storm-runoff-producing zones on glacial-till lands expand and contract seasonally and during storms; the variable size of the zones influences the quantity and timing of runoff. Knowledge of antecedent soil moisture, soil characteristics, and rainfall intensity and duration is needed to determine the extent of the runoff-producing zones or the runoff response to a rainstorm.

(9) Wetlands, lakes, ponds, and overbank floodplains are important floodwater storage areas that reduce flood peaks.

(10) Channel losses recharge the ground-water aquifer and reduce flood peaks downstream.

(11) Ground-water flow boundaries are not necessarily coincident with surface-drainage boundaries. It is likely that water moves from one basin to another through the ground-water pathway.

\section{SIMULATION OF RUNOFF}

The validity of the conceptual model was tested by runoff simulations. The rainfall-runoff relations summarized in the previous section by the generalizations about runoff were incorporated into a numerical model that simulated the processes in the study basins.
A typical basin in the study area is a patchwork of different land uses overlying a natural landscape of varying physical characteristics of soil, vegetation, and topography. The result is a watershed made of hundreds of land units scattered throughout the basin. Each unique land unit produces runoff in different locations in the basin. The complexity of integrating the runoff of the large number of land units into one measurable streamflow at the mouth of a basin necessitates the use of a numerical model. If a numerical model can simulate the processes of runoff defined by the conceptual model and tests of the numerical model to simulate runoff are successful, then there is reasonable assurance that the conceptual model is valid.

Simulation of runoff also provides a method to assess how changes in land use affect runoff characteristics in the study basins. During construction of the numerical model, a land segmentation scheme grouped land units that exhibit similar runoff responses into land segments so that a basin was represented by a few or many of the land segments of known areal extent within the basin. Thus, by changing the proportion of the areas of different land segments to a new proportion, any scenario of changing land use in a basin could be simulated. Then the new basin model could be rerun and changes in streamflow could be compared with original simulated streamflows.

The numerical model chosen to make the runoff simulation was Hydrological Simulation Program-FORTRAN (HSPF). HSPF had been used successfully in similar studies by Dinicola (1990) and Berris (1995) in nearby regions of the Puget Sound Lowland on similar basins. In this application of HSPF, one basin model, the Clear-Clarks Basin model, was constructed for the five creeks of the Clear-Clarks Basin: Swan, Clear, Canyon, West Fork Clarks, and Diru Creeks. Runoff simulations were made for this basin model for the 1990 and 1991 water years when observed discharge data were available for comparison. A second basin model, the Clover Basin model, was constructed for Clover Creek, and runoff simulations were made for the 1991 and 1992 water years, the period of record for observed discharge on Clover Creek. The remainder of this chapter describes (1) how the HSPF model simulates runoff, (2) how the basin models were constructed, and (3) how the basin models were calibrated to observed data. 


\section{Description of the Numerical Model}

The HSPF numerical model contains many features that make it well suited to simulate runoff according to the conceptual model of the study area.

(1) HSPF is a deterministic hydrologic model capable of simulating various hydrologic processes including those present in the conceptual model.

(2) HSPF is a continuous-simulation model that maintains an accounting of changes in soil moisture conditions over time. Precipitation is a usersupplied input to the model that is generally a time series of measured precipitation. This feature allows accurate definition of storm intensity and duration.

(3) HSPF uses a distributed parameter approach that divides the basin into a large number of subareas to account for variations of hydrologic responses within a basin.

(4) HSPF contains flexible network operations that allow the outputs of various runoff production processes to be directed to specific locations within or outside the simulated basin.

(5) HSPF contains flow routing operations that can approximate the flow of water in natural and man-made channels.

The HSPF user defines how the model will simulate hydrologic processes and basin characteristics for a particular watershed with a User's Control Input file (UCI). Within the UCI, operations are arranged in program blocks. For example, the NETWORK block describes the hydrologic links to be simulated. One such link may be that runoff output from a particular land segment will be applied to a particular channel reach. These programming blocks are referred to in the following sections on model description and construction. Complete listings of UCI files for the basin models are given in the supplemental data section of this report.

The method used by HSPF to simulate runoff processes can be visualized as a network of reservoirs that receives inflows of water and then releases water as an outflow. Initial input of water to the network of reservoirs is rainfall supplied by the user as a time series of inches of rainfall per time step. (Metric units are available for all the computations in the HSPF program, but the option was not used in this study.) The rate of flow and the pathway water takes between the reservoirs are controlled by a system of valves. The final destination of water simulated in this system is to the atmosphere by evapotranspiration (ET), to deep or inactive ground water, or to streamflow. Evapotranspiration may remove available water from several of the reservoirs and direct it out of the system at a rate that is a function of daily PET supplied by the user as a time series in inches per day. The HSPF model maintains a continuous accounting of inflow, outflows, and amount of storages as inches of water. It maintains a complete balance between all inflows and outflows that are simulated or supplied by the user. It also computes volumes by multiplying the inches of runoff by the area of the land unit represented.

The size of the reservoirs, the operation of the valves, and rate of outflow between the reservoirs are controlled by a set of user-defined, process-related parameters. The parameters define how hydrologic processes governing surface retention and runoff from a land segment are simulated by the numerical model. A different set of parameters is defined for each land segment to be simulated. A list of the process-related parameters and their definitions is given in table 1. Initial values for these parameters, which are abstract or difficult to measure in the field, were obtained from Dinicola (1990) for a similar study in King and Snohomish counties and some of these values were adjusted during the calibration process.

HSPF distinguishes between pervious land segments and impervious land segments with the IMPLND and PERLND program blocks in the UCI file. These two program blocks contain the process-related parameters for these two sets of land segments. The process of runoff from impervious land is simple, and the simulation of this process by HSPF is discussed first. Simulation of runoff from pervious land segments is more involved and is briefly discussed second. The reader is referred to pages 158 to 176 and pages 209 to 212 of the HSPF users manual for more complete discussions (U.S. Environmental Protection Agency, 1984). 
Table 1--Definition of process-related Hydrological Simulation Program-FORTRAN (HSPF) parameters controlling the simulation of runoff from hillslopes in Pierce County, Washington

AGWETP - Fraction of available-PET demand that can be met with stored ground water. Simulates ET from phreatophytes in general.

AGWRC - Ground-water recession parameter. An index of the rate at which ground water drains from the land.

BASETP - Fraction of available-PET demand that can be met with ground-water outflow. Simulates ET from riparian vegetation.

CEPSC - Interception storage capacity of plants.

DEEPFR - Fraction of ground water that does not discharge to the surface within the boundaries of the modeled area.

INFEXP - Infiltration equation exponent. Controls the rate at which infiltration decreases with increasing soil moisture.

INFILD - Ratio of the maximum to mean infiltration rate of a pervious area. Accounts for the degree of variations in the infiltration capacity.

INFILT - Infiltration capacity. An index to the infiltration capacity at the soil surface and an indirect index of the percolation rate from the bottom of soil zone.

INTFW - Interflow index. In combination with INFILT, an index to the quantity of water that infiltrates and flows as shallow subsurface runoff.

IRC - Interflow recession parameter. An index of the rate at which shallow subsurface flow drains from the land.

KVARY - Ground-water outflow modifier. An index of how much influence recent recharge has on ground-water outflow.

LSUR - Average length of the overland flow plane.

LZETP - Lower-zone ET. An index to the density of deep-rooted vegetation on a pervious area.

LZSN - Lower-zone nominal storage. An index to the soil moisture holding capacity.

NSUR - Average roughness of the overland flow plane.

RETSC - Retention storage capacity of impervious areas.

SLSUR - Average slope of the overland flow plane.

UZSN - Upper-zone nominal storage. An index to the quantity of depression and surface layer storage of a pervious area. 


\section{Impervious Land Segments}

Simulation of runoff from impervious surfaces by HSPF within the IMPLND program block is made with two storage reservoirs, retention storage and detention storage, and allows rapid, direct overland flow to be simulated in agreement with the conceptual model of runoff from impervious areas. Rainfall is applied to retention storage and is removed by ET. When retention storage is exceeded, additional rainfall moves to detention storage, a temporary surface storage of water that supplies the water for overland flow. The capacity of retention storage is defined by the parameter RETSC. Detention storage is unlimited. Water is routed, according to the ChezyManning equation, out of detention storage each time step as overland flow until the storage has been depleted. Average length, slope, and roughness of the overland flow plane are supplied by the user, who specifies values for parameters LSUR, SLSUR, and NSUR. Adjusting these values will adjust the rate of flow from the impervious land segment, which will be a relatively quick rate of flow unless unreasonably large LSUR and NSUR values or unreasonably low SLSUR values are used.

\section{Pervious Land Segments}

The PERLAND program block of HSPF is more complex than the IMPLND program block because it contains more possible flow paths and storages of water within the system. Also, PERLND allows the simulation of several flow processes at the same time that are dependant on current soil-moisture conditions and moisture input. These complexities are required to simulate the several runoff processes described in the conceptual model. A schematic diagram representing the simulation of runoff by HSPF from pervious land segments is shown on figure 2 .

Distribution of water available for infiltration and runoff in HSPF begins with rainfall applied to interception storage. Moisture exceeding the storage capacity of interception storage defined by parameter CEPSC becomes available for infiltration into the ground. Parameters INFILT, INFEXP, and INFILD are all involved with distribution of water at this point. INFILT is an index of the average rate of water entering the soil as direct infiltration under dry soil conditions. INFEXP is added to the infiltration algorithm to vary the rate of direct infiltration with varying quantities of soil moisture. Large values of INFEXP for a particular land segment can be used to sim- ulate a large infiltration capacity under dry soil conditions that rapidly decreases to low infiltration capacity as soil moisture increases, and thereby the land segment more readily produces saturation overland flow. Soil moisture is determined by the model as a ratio of the quantity of water in the lower zone storage to the user-defined nominal value, the LZSN parameter. INFILD is a ratio of maximum infiltration capacity to the average infiltration capacity of a land segment. It is used in the infiltration algorithms as a linear probability density function to account for areal variation of infiltration that may be used to simulate the variable-source concept of storm runoff described in the conceptual model.

Subsurface flow processes described in the conceptual model are partly simulated in the HSPF numerical model within the upper zone storage and are influenced by the quantities of water stored in the lower zone. In the HSPF numerical model, water that does not infiltrate directly becomes available for upper zone storage and delayed infiltration of water into the soil. The upper zone of the soil is generally considered the depth of tillage, or in the context of this study, it is the topmost part of the soil horizon that accounts for the amount of depression and surface layer storage of a pervious area. The lower zone extends from the upper zone to the bottom of the root zone. The fraction of available water that enters upper zone storage is a function of the ratio of the quantity of water currently in upper zone storage to a nominal storage value defined by the UZSN parameter. As the quantity of water in the upper zone storage increases, the fraction of available water that enters the upper zone storage decreases. The quantity of water that percolates from the upper zone storage as delayed infiltration is computed from an empirical expression relating percolation to a function of the current storage in the upper zone, the current soil moisture (lower zone), and parameters UZSN and INFILT. Decreases in storage in the upper zone or increases in soil moisture (lower zone) will decrease the rate of delayed infiltration.

Overland flow and interflow runoff processes described in the conceptual model are also simulated in the HSPF numerical model. In the numerical model, water that does not directly infiltrate or become directed into upper zone storage may become overland flow or interflow. The proportion of available water that becomes either overland flow or interflow is determined from an index parameter, INTFW. The higher the value given to INTFW, such as might be assigned to undisturbed land areas, the higher the proportion of available water that will 
flow into interflow storage. Flow from interflow storage to the stream channel is determined for each time step by a function of interflow storage, inflow into interflow storage, and the recession parameter IRC. IRC is the ratio of the present rate of outflow to outflow 24 hours earlier. The conceptual model states that the rate of subsurface flow is proportional to the angle of the hillslope. The simulation of this concept can be accomplished by assigning relatively high values of IRC on the steep land segments that will increase the rate of interflow and low values on the flat land segments to simulate slower rates of interflow. In the numerical model overland flow storage is the counterpart of detention storage in the impervious land segments. Flow from overland flow storage to the channel is governed by the same equations as those used in the IMPLND program block, and it is controlled by the userspecified parameters LSUR, SLSUR, and NSUR.

The conceptual model emphasizes the role of ground-water flow in the runoff process in the study area, and this role is accommodated in the numerical model. In the numerical model, water that has infiltrated becomes either lower zone storage or ground water. The fraction of this water that becomes lower zone storage is a function of the current soil moisture and the only outlet from lower zone storage is through ET. The DEEPFR parameter defines the fraction of ground water that becomes deep or inactive ground water. Deep or inactive ground water can be routed to any desired location in the network representing a basin, which may be useful in simulating the movement of ground water from one subbasin to another, one of the runoff processes described in the conceptual model. The remaining water not entering deep or inactive ground water enters ground-water storage. Two user-specified parameters, KVARY and AGWRC, the current groundwater storage, and an index to ground-water slope are used to determine outflow (base flow) from storage into the stream channel. The index is a measure in inches that is increased each time interval by inflow to ground-water storage and decreased by 3 percent each day. KVARY allows the relation of outflow to storage to be nonlinear. AGWRC is a recession constant that is the ratio of current outflow to outflow 24 hours earlier.

ET is only briefly mentioned in the conceptual model, but it is essential to the water budget of a watershed, and the HSPF numerical model allows simulation of ET from five separate sources. In the numerical model, ET removes water from base flow if it is available at the potential rate of ET times the user-defined parameter BASETP, a fraction from zero to one. The remaining ET demand is met by removal of water from the following storage locations in this order: interception storage, upper zone storage, ground-water storage, then lower zone storage. Interception storage will supply moisture at the potential rate if the ratio of upper zone storage to UZSN is greater than 2.0. If it is less than 2.0, the rate of moisture supply is reduced from the potential rate. AGWETP is a parameter similar to BASETP: it is the fraction of the remaining PET that can be satisfied from active groundwater storage. Lower zone storage supplies moisture at the potential rate if it is available and if the parameter LZETP equals its maximum value of one. At values less than one, the rate is reduced by a function of current soil moisture and value of LZETP. 


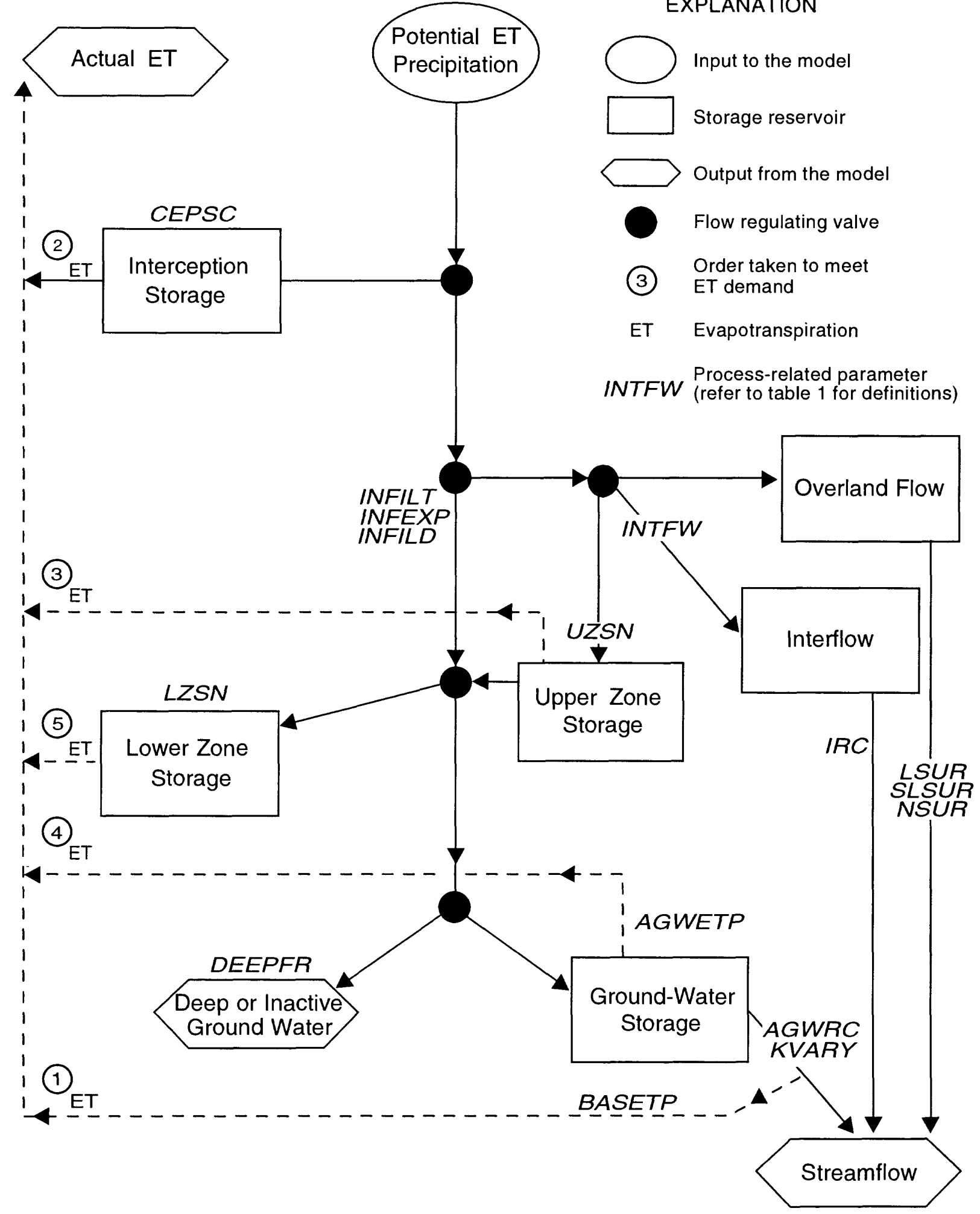

Figure 2.--Flowchart of simulated runoff from pervious land segments. 


\section{Channel Network}

The simulation of the influences of floodwater storage areas, channel losses, and ground-water flow boundaries on runoff-factors outlined in the conceptual model-is accomplished within the channel network portion of the numerical model. After the PERLND and IMPLND blocks have simulated runoff from the land segments, the runoff is directed through a channel network defined by the NETWORK, RCHRES (reach-reservoir), and FTABLE (flow table) blocks of programming in the UCI file. A basin is divided by a user into subbasins as part of the land segmentation scheme. Each subbasin has a reach of channel that drains runoff from land segments within it. (In some cases a portion of the runoff from particular land segments may be directed elsewhere.) The NETWORK block directs runoff from land segments to the upper end of a particular channel reach. Runoff is routed through the channel by a storage-routing technique sometimes referred to as a kinematic wave technique (refer to pages 224-240 of the users manuel, U.S. Environmental Protection Agency, 1984). The RCHRES block of the HSPF model routes flow from the top of the reach to the outlet. Length, slope, and initial volume of each reach are assigned by the user. A flow table (FTABLE) for each reach is also supplied to the model by the user. FTABLE's relate the volume of water in the reach to the outflow from the reach at several increments of depth and surface area. The relation of volume of water to outflow is a function of channel geometry, slope, and channel roughness. By use of this hydraulic information, flows may be routed through reservoirs, open channels that include floodwater storage areas, and pipes with reasonable accuracy when variable backwater or pressure flow conditions do not exist. FTABLE's may have multiple outlets that allow the simulation of channel losses. Outflow from a reach is generally added to the inflow of the next reach downstream as defined in the NETWORK block. In this way, the numerical model represents a watershed as a network of reaches receiving point sources of runoff from different land segments and possibly ground-water inflow from a simulated aquifer. The outflow from any of the reaches may be stored and tabulated or plotted as a hydrograph.

\section{Construction of Numerical Basin Models}

Construction of the numerical basin models for the study area begins with division of the basins into individual subbasins. A representative rainfall record collected by nearby recording rain gages operated for this study was assigned to each subbasin. Areas of similar physical properties and runoff responses were grouped into land segments, and their areal extent within each subbasin was determined. Hydraulic characteristics of the main channel within each subbasin were measured in the field or computed from maps. A network for each basin model was devised to direct flows from land segments, outside sources, and channel reaches to their proper destinations. These destinations were determined from observations in the field, from comparisons of observed and simulated runoff, and from guidelines proposed by the conceptual model. All of these activities were completed before any model runs were made. However, during the calibration process, some changes were made to the network, to the FTABLE's for several reaches, and to several of the process-related parameter values. The remainder of this section describes the calibration process in more detail.

\section{Subbasins}

The three basins were divided into subbasins, which could be defined and examined in more detail than an undivided basin (fig. 3 ). The subbasins were delineated from county drainage maps (scale of 1:2,400) where available. A small part of the west side of the lower Swan Creek Basin was delineated from City of Tacoma drainage maps (same scale). For the southern part of the Clover Creek Basin, no county or city drainage maps existed, so for this area, U.S. Geological Survey 7.5 minute topographic maps at a scale of 1:24,000 were used to delineate the drainage boundaries.

Subbasins were defined by surface drainage boundaries that were somewhat modified from the natural boundaries because culverts and pipes linked drainage areas together. The exceptions to this rule were in the southern and eastern parts of the watershed of the main stem of Clover Creek, where dominant surficial deposits are glacial outwash. Ground-water flow processes dominate, and surface drainage channels do not exist except in large impervious areas. Contributing areas to the upper main stem of Clover Creek and upper Spanaway Creek were defined by ground-water flow boundaries; doing so made the shape and areal extent of subbasins SP1B, CL1B, CL2B, and CL5 substantially different from contributing areas that surface drainages would have defined (dashed lines on fig. 3b). Ground-water flow boundaries were taken from a potentiometric map of the shallow ground-water system produced from well-level data by Brown and Caldwell (1985, fig. 5-21).

The outlets of the subbasins were sometimes located at natural hydrologic features or geologic discontinuities. For example, these locations might be at the confluence of two streams or at a change in geology where soils change from a glacial till soil to an outwash soil. Often the outlet of a subbasin was situated at a stream gaging location so that the output of the numerical model that represented simulated discharge at the mouth of a subbasin could be compared with observed data. Fifty-one subbasins were delineated to represent the study basins. They are listed in table 2 with their sizes in acres and square miles. 
Drains outside of the study area.

Recharge area outside the surface-water drainage

Channel reaches

- - - Subbasin boundaries

Surface-water drainage

boundary

GAGE AND USGS

STATION NUMBER

12102200

(C) Crest-stage streamgage

12102190

- Continuous-recording streamgage

470948122211801

Precipitation gage

\section{SUBBASIN CODES}

(Subbasins are numbered for each creek basin beginning at the head-waters and ending at the mouth)

\section{S Swan Creek \\ C Clear Creek \\ CAN Canyon Creek \\ WF West Fork Canyon Creek \\ D Diru Creek}

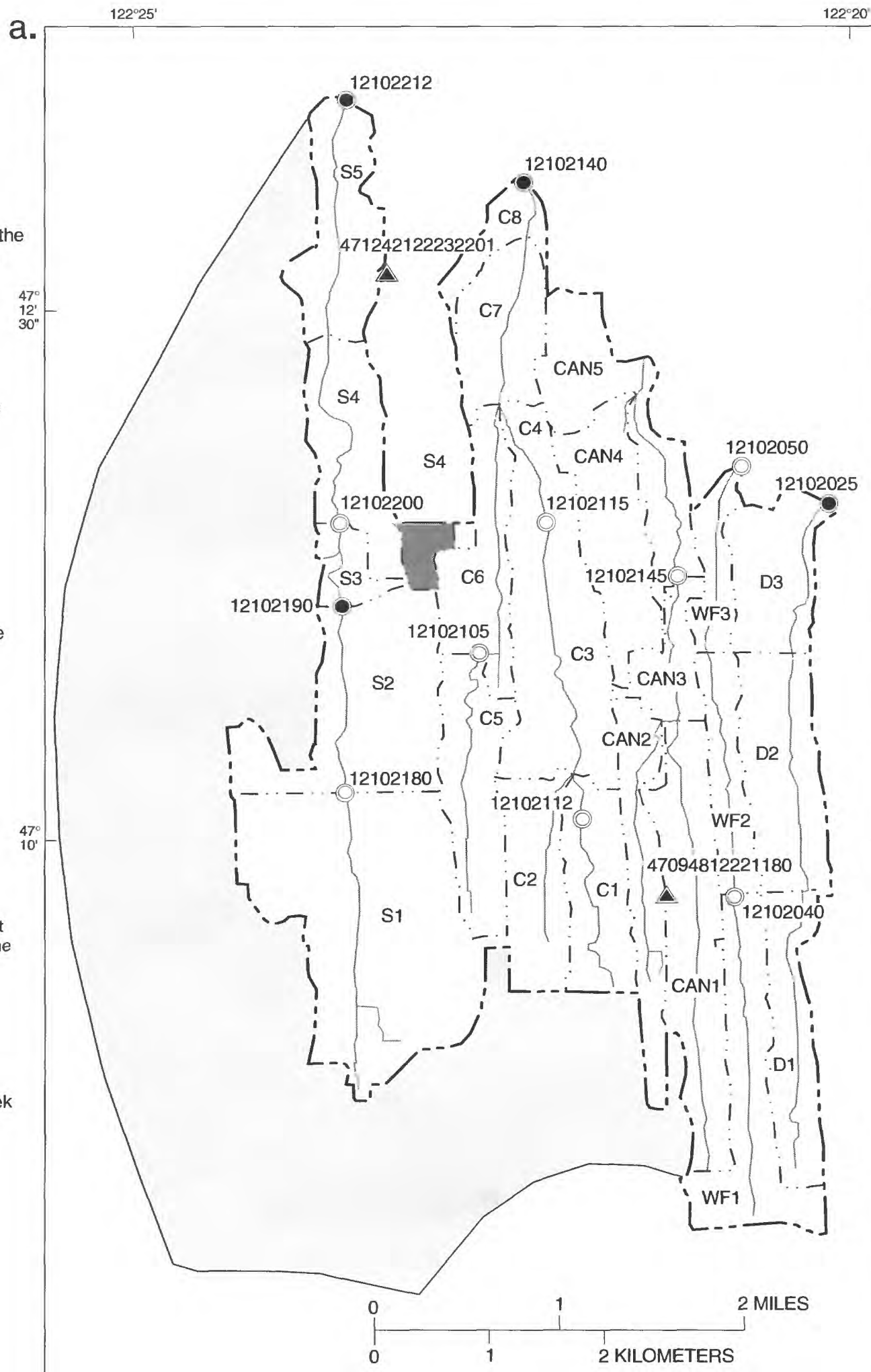

Figure 3.-Subbasin divisions, channel reaches, streamflow gages, and rain gages for the (a) Clear-Clark Basin model, Pierce County, Washington. 
b.

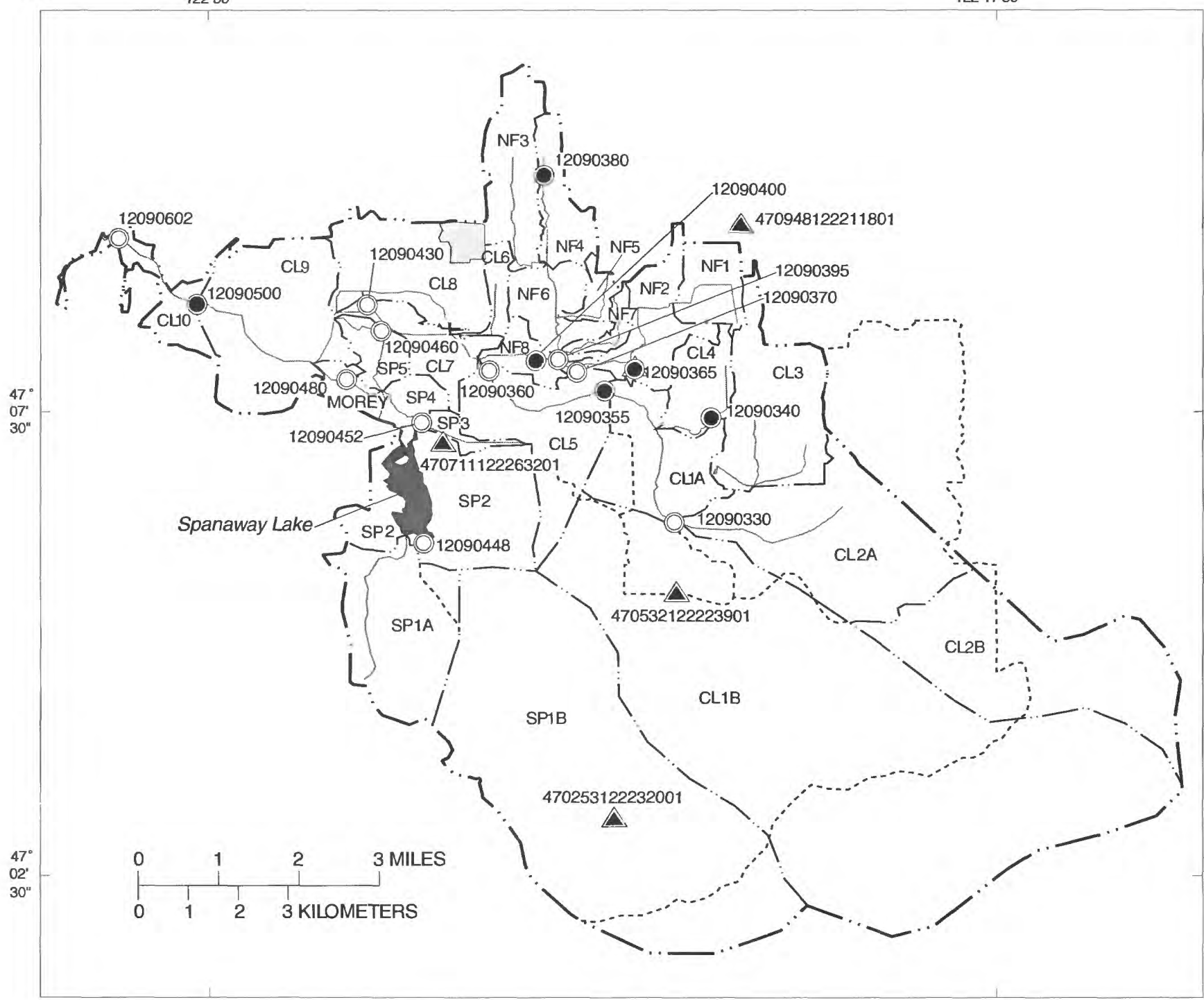

EXPLANATION

Drains outside of study area

Channel reaches

Basin boundary

Surface-water boundaries not used to define subbasins

-.. Subbasin boundaries
GAGE AND USGS STATION NUMBER

12090330

(0) Crest-stage streamgage

12090380

Continuous-recording streamgage

470948122211801

$\triangle$ Precipitation gage

\section{SUBBASIN CODES}

(Subbasins are numbered for each creek basin beginning at the headwater and ending at the mouth.)

CL Clover Creek

MOREY Morey Creek

NF North Fork Clover Creek

SP Spanaway Creek

Figure 3.--Continued (b) Clover Creek Basin model. 
Table 2.--Area of land segments as a percent of subbasins and area of subbasins, Pierce County, Washington

[EIA, effective impervious areas, all slopes; TFF, till soils, forest cover, flat slopes; TFM, till soils, forest cover, moderate slopes; TFS, till soils, forest cover, steep slopes; TGF, till soils, grass cover, flat slopes; TGM, till soils, grass cover, moderate slopes; TGS, till soils, grass cover, steep slopes; OF, outwash soils, forest cover, all slopes; OG, outwash soils, grass cover, all slopes; SA, saturated soils, all covers, all slopes

\begin{tabular}{|c|c|c|c|c|c|c|c|c|c|c|c|c|}
\hline \multirow[b]{2}{*}{$\begin{array}{l}\text { Subbasin } \\
\text { codes }^{2}\end{array}$} & \multicolumn{10}{|c|}{ Areas of land-segment areas, in percent of total area of subbasin ${ }^{1}$} & \multicolumn{2}{|c|}{$\begin{array}{l}\text { Total area } \\
\text { of subbasin }\end{array}$} \\
\hline & EIA & TFF & TFM & TFS & TFG & TGM & TGS & OF & OG & $\mathrm{SA}$ & (Acres) & $\begin{array}{l}\text { (Square } \\
\text { miles) }\end{array}$ \\
\hline \multicolumn{13}{|c|}{ Swan Creek Basin } \\
\hline S1 & 10.2 & 7.8 & 0 & 0 & 70.5 & 0 & 0 & 0 & 0 & 11.5 & 958.3 & 1.50 \\
\hline $\mathrm{S} 2$ & 3.4 & 13.3 & 1.1 & 0 & 60.6 & 1.3 & 0 & 0 & 0 & 20.3 & 548.0 & 0.86 \\
\hline S3 & 3.1 & 49.5 & 0.7 & 0 & 39.1 & 2.6 & 0 & 0 & 0 & 5.0 & 90.5 & 0.14 \\
\hline S4 & 7.4 & 18.6 & 3.6 & 11.4 & 57.3 & 0.4 & 1.0 & 0.4 & 0 & 0 & 296.9 & 0.46 \\
\hline \multirow[t]{2}{*}{ S5 } & 0.8 & 0.8 & 7.7 & 24.9 & 0 & 4.1 & 0.7 & 25.7 & 35.0 & 0.2 & 310.9 & 0.49 \\
\hline & & & & & & & & & \multicolumn{2}{|c|}{ Total for basin } & $2,204.6$ & 3.45 \\
\hline \multicolumn{13}{|c|}{ Clear Creek Basin } \\
\hline $\mathrm{Cl}$ & 7.5 & 32.6 & 2.7 & 0 & 41.7 & 9.1 & 0 & 0 & 0 & 6.5 & 242.7 & 0.38 \\
\hline $\mathrm{C} 2$ & 7.8 & 3.8 & 1.2 & 0 & 73.8 & 4.3 & 0 & 0 & 0 & 9.1 & 243.0 & 0.38 \\
\hline $\mathrm{C} 3$ & 2.8 & 26.6 & 2.9 & 0.1 & 51.3 & 6.9 & 0 & 0 & 0.8 & 8.7 & 467.0 & 0.73 \\
\hline $\mathrm{C} 4$ & 5.2 & 15.4 & 3.8 & 19.3 & 53.0 & 0.9 & 2.4 & 0 & 0 & 0 & 111.7 & 0.18 \\
\hline $\mathrm{C} 5$ & 3.1 & 7.1 & 1.5 & 0 & 57.4 & 13.6 & 0 & 0 & 0 & 17.3 & 292.8 & 0.46 \\
\hline C6 & 2.5 & 19.1 & 1.0 & 13.2 & 51.1 & 5.2 & 7.9 & 0 & 0 & 0 & 263.6 & 0.41 \\
\hline $\mathrm{C} 7$ & 3.1 & 15.0 & 0 & 27.3 & 22.4 & 4.5 & 12.1 & 4.9 & 10.5 & 0 & 244.0 & 0.38 \\
\hline \multirow[t]{2}{*}{$\mathrm{C} 8$} & 6.5 & 14.7 & 3.2 & 18.4 & 25.3 & 20.0 & 6.4 & 2.1 & 3.3 & 0 & 110.3 & 0.17 \\
\hline & & & & & & & & & \multicolumn{2}{|c|}{ Total for basin } & $1,975.1$ & 3.09 \\
\hline \multicolumn{13}{|c|}{ Canyon Creek Basin } \\
\hline CAN1 & 11.7 & 13.7 & 7.2 & 0 & 48.3 & 19.1 & 0 & 0 & 0 & 0 & 436.6 & 0.68 \\
\hline CAN2 & 16.8 & 20.2 & 9.6 & 0 & 23.3 & 16.2 & 0 & 0 & 0 & 13.9 & 244.1 & 0.38 \\
\hline CAN3 & 16.2 & 4.0 & 9.5 & 2.8 & 27.2 & 40.2 & 0 & 0 & 0 & 0 & 143.7 & 0.22 \\
\hline CAN4 & 12.8 & 11.9 & 0.7 & 5.5 & 55.4 & 11.6 & 2.1 & 0 & 0 & 0 & 304.7 & 0.48 \\
\hline \multirow[t]{2}{*}{ CAN5 } & 4.4 & 12.9 & 1.9 & 16.7 & 40.9 & 2.4 & 5.6 & 2.7 & 12.0 & 0.5 & 353.2 & 0.55 \\
\hline & & & & & & & & & \multicolumn{2}{|c|}{ Total for basin } & $1,482.3$ & 2.31 \\
\hline \multicolumn{13}{|c|}{ West Fork Clarks Creek Basin } \\
\hline WF1 & 7.8 & 36.7 & 3.4 & 0 & 37.7 & 13.2 & 0 & 0 & 0 & 1.1 & 346.6 & 0.54 \\
\hline WF2 & 11.2 & 21.1 & 12.1 & 0 & 14.7 & 40.8 & 0.1 & 0 & 0 & 0 & 167.6 & 0.26 \\
\hline \multirow[t]{2}{*}{ WF3 } & 7.4 & 9.1 & 9.7 & 30.3 & 21.2 & 7.3 & 2.1 & 3.4 & 8.3 & 1.2 & 135.2 & 0.21 \\
\hline & & & & & & & & & \multicolumn{2}{|c|}{ Total for basin } & 649.4 & 1.01 \\
\hline
\end{tabular}


Table 2.--Area of land segments as a percent of subbasins and area of subbasins, Pierce County, Washington--Cont.

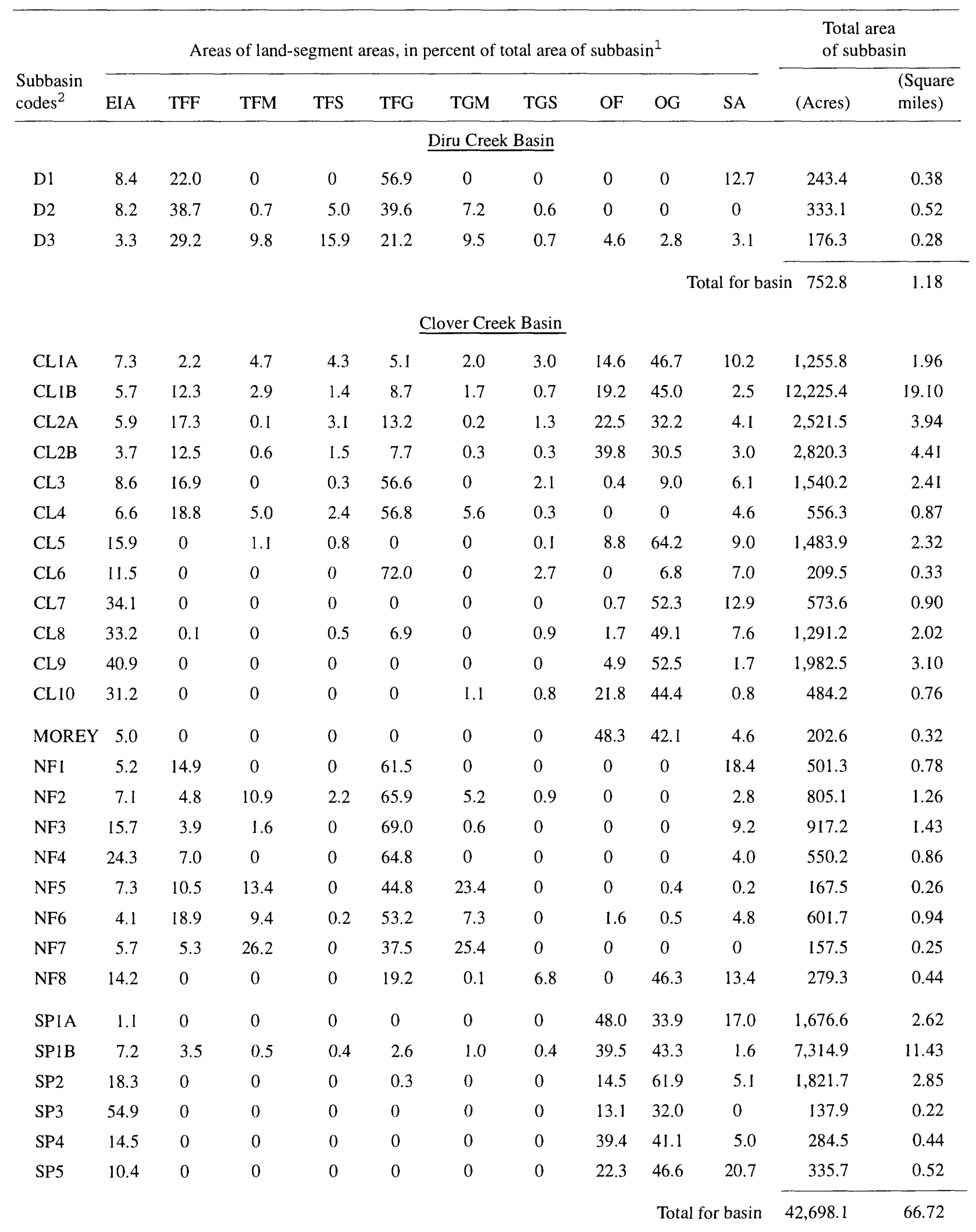


Table 2.--Area of land segments as a percent of subbasins and area of subbasins, Pierce County, Washington--Cont.

\begin{tabular}{|c|c|c|c|c|c|c|c|c|c|c|c|c|}
\hline \multirow[b]{2}{*}{ Subbasin } & \multicolumn{10}{|c|}{ Land-segment areas, in percent of total area of subbasin ${ }^{1}$} & \multicolumn{2}{|c|}{$\begin{array}{l}\text { Total area } \\
\text { of subbasin }\end{array}$} \\
\hline & EIA & TFF & TFM & TFS & TFG & TGM & TGS & OF & OG & SA & (Acres) & $\begin{array}{l}\text { (Square } \\
\text { miles) }\end{array}$ \\
\hline \multicolumn{13}{|c|}{ Catchments $^{3}$} \\
\hline \multicolumn{13}{|c|}{ Cow pasture } \\
\hline & 0 & 36.2 & 0 & 0 & 63.8 & 0 & 0 & 0 & 0 & 0 & 89.5 & 0.14 \\
\hline \multicolumn{13}{|l|}{ Suburban } \\
\hline & 23.2 & 0 & 0 & 0 & 76.8 & 0 & 0 & 0 & 0 & 0 & 9.5 & 0.01 \\
\hline \multicolumn{13}{|c|}{ Mixed-use } \\
\hline & 15.3 & 11.2 & 0 & 0 & 71.0 & 0 & 0 & 0 & 0 & 2.5 & 120.1 & 0.19 \\
\hline
\end{tabular}

\section{Land Segments}

Dinicola (1990) presented a method of dividing a basin into land segments that can be easily identified by their physical traits and that exhibit a distinct runoff response to rainfall. Dinicola's method used the U.S. Department of Agriculture (USDA) soil series descriptions and maps from published county soil surveys to delineate pervious land segments within the study basins. Impervious land segments were mapped and computed from land-use maps. Each land-segment type had its own set of process-related model parameters, which were defined to simulate runoff within the context of the conceptual model and were calibrated by comparison of observed discharge data and simulated discharge data. Berris (1995), using the same method with minor alterations, and Dinicola (U.S. Geological Survey, written commun., 1994), in a follow-up study, validated this land segmentation scheme as a workable methodology to divide a watershed in the Puget Sound Lowland into meaningful hydrologic units. The same method was used in this study. The land segmentation method defined nine pervious land segments based on a combination of soil type, land cover, and slope.
Soils in the study area are described as soil series in the soil survey for Pierce County (U.S. Department of Agriculture, 1979). To begin land segmentation of the study area, the soils series were divided into three groups: (1) soils derived from glacial till deposits, (2) soils derived from glacial outwash deposits, and (3) soils formed under saturated conditions. Generally, it was clear from the descriptions which soil series belonged in each of the three classes. Table 3 lists the soils series of all soils found in the study area and associated land-segment groups.

Till and outwash soils are subdivided into two land-cover categories, forest cover and grass cover. Forest cover represents undisturbed landscapes, and grass cover represents disturbed landscapes that include pastures and lawns typically found in rural areas or vacant lots found in more urbanized areas. Saturated soils are found in wetland areas, which are generally inundated only seasonally. Till soils are subdivided further into three slope classes that agree with the slope classes used by the soil survey, flat soils ( $0-6$ percent slope), moderate soils (6-15 percent slope), and steep soils (15 percent and greater slopes). The complete listing of areas of land segments as a percentage of the subbasin area is shown on table 2 . 
Table 3--Land segment groups used in runoff simulation and associated soil series found in the study area in Pierce County, Washington (U.S.Department of Agriculture, 1979)

Land-segment groups

Till

\section{Outwash}

Saturated
Pierce County area soil series

Alderwood gravelly sandy loam

Kapowsin gravelly loam

Kitsap silt loam

McKenna gravelly loam

Xerochrepts

Xerorthents, fill areas

Everett gravelly sandy loam

Everett stony sandy loam

Indianola loamy sand

Neilton gravelly loamy sand

Nisqually loamy sand

Rangar sandy loam

Spanaway gravelly sandy loam

Aquic Xerofluvents

Bellingham silty clay loam

Briscot loam

Dupont muck

Norma fine sandy loam

Shalcar muck

Snohomish silty clay loam

Spana loam

Sultan silt loam

Tanwax muck

Tisch silt 
Effective impervious land segments (EIA) represent impervious surfaces directly connected to stream channels. Effectiveness varies with degree of urbanization. In low-density rural areas, impervious surfaces are a small percentage of the total area, and drainage networks of curbs, gutters, and storm sewers are not well developed. Most of the runoff from these impervious areas simply augments input to surrounding pervious land segments (an example is a roof draining to a lawn). Thus, effectiveness of impervious areas in low-density rural areas to direct surface runoff directly into the stream channel is low. As urbanization increases, the impervious area increases, and the hydraulic connectivity of these surfaces to the stream channel increases; therefore, the effectiveness of surface runoff to quickly become streamflow increases. Based on three reports that compared land use with total impervious area and the percentage of area that is effective impervious area (Alley and Veenhuis, 1983; Laenen, 1983; and Prych and Ebbert, 1986), Dinicola (1990) used the following table to compute the percent of total area that is EIA from five categories of land use:

\begin{tabular}{|c|c|c|}
\hline Land use & Housing density & $\begin{array}{l}\text { EIA, in } \\
\text { percent of } \\
\text { total area }\end{array}$ \\
\hline Low density development & One unit per 2 to 5 acres & 4 \\
\hline Medium density development & One unit per acre & 10 \\
\hline Suburban development & Four units per acre ${ }^{1}$ & 23 \\
\hline High-density development & $\begin{array}{l}\text { Multi-family or } \\
\text { high density }\end{array}$ & 48 \\
\hline $\begin{array}{l}\text { Commercial, industrial, or } \\
\text { transportation facilities }\end{array}$ & -- & 85.5 \\
\hline
\end{tabular}

\footnotetext{
${ }^{1}$ In this study, housing density for suburban land use was terpreted to include housing densities of one to four units per acre
}

In order to compute the areas of the nine different land segments for each subbasin, a digitized coverage of the soil series groups representing the till (including the three slope groups), outwash, and saturated land segments was made on a geographic information system (GIS) from the county soil maps. In order to compute the areas of effective impervious land segments, a digitized land-use coverage was made for the Clear and Clarks Creek Basins from aerial photo prints dated 1985. A set of aerial photos taken in 1989 was used to delineate land use for the Clover Creek Basin. Other than several large, new developments not shown on the aerial photos and accounted for in the land-use coverage, it is assumed that land use has not changed significantly since the aerial photo dates and the data collection period. Land-use categories included forested areas and grass areas along with the five development categories listed in the previous table. In low density developed areas 4 percent of the area was designated as effective impervious area, and the remainder was classified as forested or grass. In the other development categories, land cover that was not designated as effective impervious area was assumed to be grass cover. A third coverage, containing the subbasin boundaries of the study area, was also digitized. The three coverages were combined to produce the acreage of each of the nine pervious land segments and the acreage of EIA or the impervious land segment for each subbasin. Table 2 presents the distribution of the land segments for each subbasin as a percent of the total area of the subbasin.

Two distinct patterns in the distribution of landsegment types are evident in the study area. The northcentral part of the study area, including the Clear, Clarks, and North Fork Clover Creek Basins, is composed mostly of till-soil land segments ( 80.3 percent of the area). One till segment, the till-grass-flat slopes segment (TGF), dominates the land-segment types of the region (51.0 percent of the total area). EIA land segments occupy 8.7 percent, outwash land segments occupy 4.2 percent, and saturated land segments occupy 6.8 percent of the total area. Basins of the main stem of Clover Creek and Spanaway Creek that make up the remainder of the study area have a much different distribution of till and outwash land segments. In these two basins, outwash land segments account for 64.8 percent of the total area. Till land segments occupy 20.0 percent, EIA land segments occupy 10.5 percent, and saturated land segments occupy 4.7 percent of the total area. The distribution of till, outwash, and saturated land segments is shown on figure 4 . 


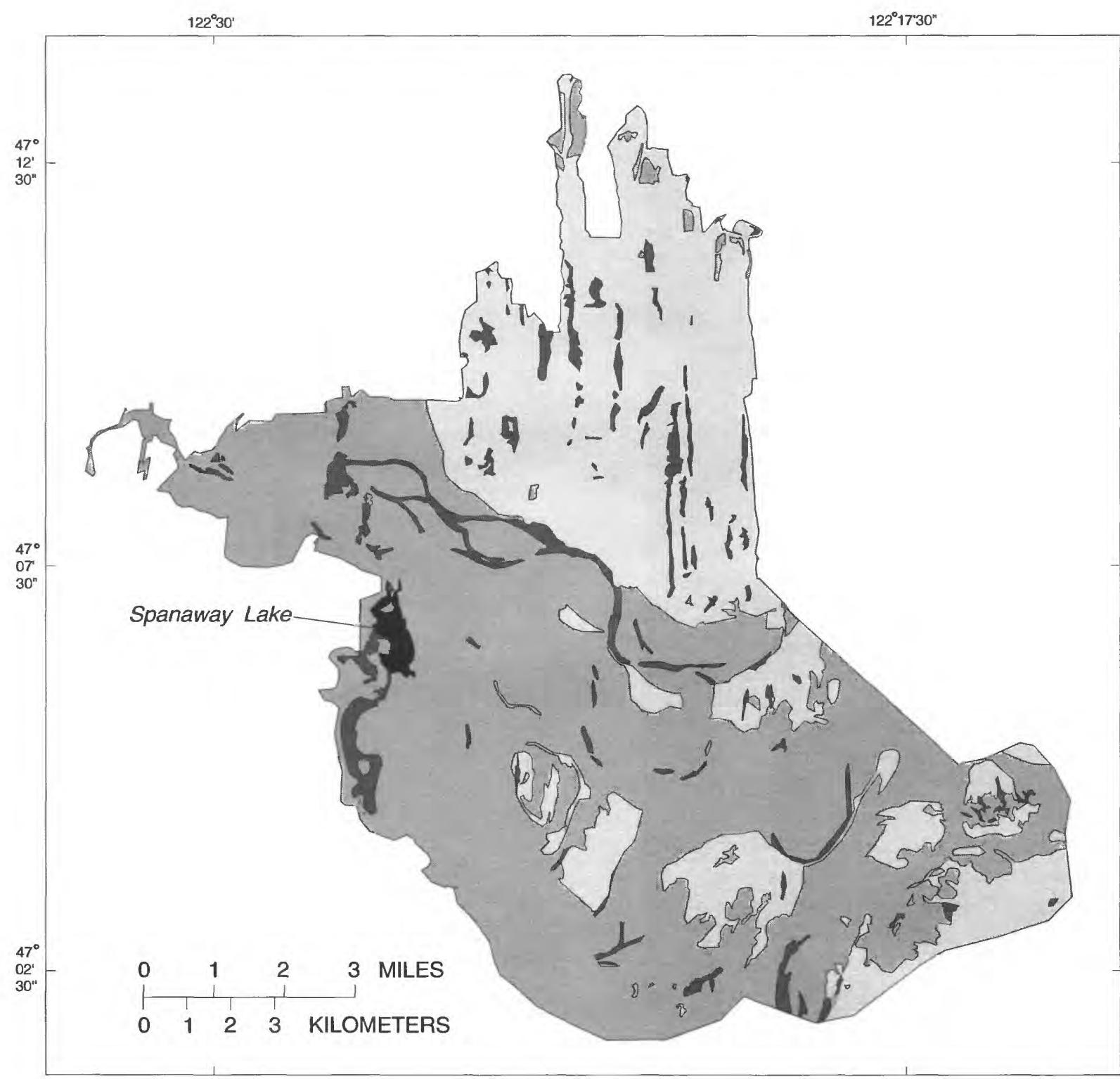

\section{EXPLANATION}

Till land segments

Outwash land segments

Saturated land segments

Figure 4.--Distribution of till, outwash, and saturated land segments in the study area in Pierce County, Washington. 


\section{Reaches}

The hydraulic characteristics of the channel reaches are defined in the RCHRES and FTABLE blocks of the UCI file. The FTABLE's were computed from a field survey of a representative cross section of each reach. Channel roughness at the cross section was estimated by assigning a value for Manning's " $n$," a roughness coefficient in Manning's equation for stream discharge. Crosssection area and hydraulic radius were computed for several flow depths from the cross-section plots. Slope and length of the reaches were computed from maps and entered into the RCHRES block. Manning's equation was used to compute the discharge at various stages in the representative cross section for a reach, and the surface area and volume of the reach were computed assuming uniform cross-section shape and constant slope. Some of the FTABLE's for Clover Creek reaches use hydraulic data compiled from flood profile information gathered by the USGS as part of a flood insurance study (Federal Emergency Management Agency, 1987). FTABLE hydraulic information was also extracted from computations of flow made directly from discharge measurements or indirectly from surveys of the hydraulic features of culverts in the channels.

HSPF allows the FTABLE's to have multiple outflows. This feature was used in a reach where channel seepage was observed or measured. Flow from the second outflow, representing channel losses, was directed to a simulated ground-water aquifer. Ground-water aquifers were represented in the model by channel reaches in the RCHRES and FTABLE blocks of the UCI, and they are referred to as "ground-water reservoirs" because of their design. To simplify its FTABLE representation and approximate the actual volume of water in the aquifer contributing to streamflows, the geometry of the simulated ground-water aquifer was chosen to be a large rectangular box. Surface area was computed to be approximately the same as the subbasins contributing to ground-water inflow, and depth was computed to be approximately equal to the maximum and minimum range of water levels of a representative well in the area with a long-term record reported by Walters and Kimmel (1968). The FTABLE that represented the ground-water reservoir had a volume equal to the depth of the box times the surface area times 0.16 , the specific yield of a gravel-sand aquifer (Linsley, Kohler and Paulhus, 1982). Assigned outflows were within the range of measured base flows of the streams, compared with a typical FTABLE for a stream, and outflows did not vary much with increased depth of water in the reservoir. Alterations of the outflows were made during the calibra- tion process, and in the case of the Clover Creek model, volumes were reduced by approximately one half until the desired simulation of base flows was attained. An effort was made to maintain a balance between the initial volume at the beginning of the water year and the final volume at the end of the water year to maintain stability in the ground-water reservoir. Instability in the ground-water reservoir might have created conditions that allowed the reservoir volumes to increase continually or decrease in volume to zero during long-term simulations. The ClearClarks Basin model had one ground-water reservoir, and the Clover Creek model had two ground-water reservoirs, each represented by a separate reach in the RCHRES block of the model. However, the ground-water reservoir is probably interconnected throughout the actual study area. Because of restricted capabilities of the HSPF model to simulate the details of ground-water flow and because of lack of information about the actual size and hydraulic characteristics of the ground-water aquifer, a simple reservoir design was used to simulate ground-water hydrology.

ET from the reaches and precipitation on the reaches probably did not substantially influence the hydrology in the basin because reaches represented a relatively small surface area, except for the reach representing Spanaway Lake. For this reach, the surface area of the lake, actual evaporation, and precipitation were computed for each time step during the model runs. For other reaches, surface area calculations, actual evaporation losses, and precipitation gains were not computed.

Each subbasin, with the exceptions of subbasins CL3, CAN1, CL1B, CL2B, and SPIB, had one reach represented in the models. The reach represented the main channel in the basin and ignored any small tributary channels. Subbasin CL3 has a channel that drains into a large depression with no outlet except a rarely used overflow. The water quickly drains into the soil and eventually reaches the stream through a ground-water pathway. This situation was represented by two reaches. The first reach represented the channel, and its outflow supplied a second reach that represented the depression. The second reach was given the actual volume of the depression, with one outlet that flowed to the Clover Creek ground-water reservoir and one overflow outlet that drained to Clover Creek directly only when the depression had filled. Subbasin CAN1 had a second reach added to represent a stormsewer network that drains the impervious land segments. The other reach represented a natural open channel that drains the previous land segments. Subbasins CL1B, CL2B, and SP1B are all large subbasins in the southeastern portion of Clover Creek in a glacial-outwash plain 
with no channel reaches. No surface-water channel reaches were simulated for these subbasins, and all runoff was simulated as ground-water flow that supplied the ground-water reservoir.

\section{Network}

The NETWORK block of HSPF dictates where the outflows from each land-segment type and the reach of each subbasin will be directed. This block of the model establishes the simulated network of stream channels within a basin, and it is important in simulating groundwater flow pathways. Several general rules were applied during construction of the network block of the models:

(1) All deep ground-water outflow from the till and saturated soil land segments was directed into the ground-water reservoir for the basin;

(2) In the three Clover Basin subbasins (CL1B, CL2B, and SP1B) where there are no stream reaches within the subbasin, all the runoff was directed to the ground-water reservoir;
(3) In all of the remaining subbasins, all active ground-water outflow from the outwash land segments was directed to the stream channel within the subbasin;

(4) All channel losses were directed to the ground-water reservoir reach;

(5) Outflows from the ground-water reservoir reach were applied to reaches where ground-water discharge sites had been identified;

(6) All overland and interflow runoff from the land segments within a subbasin was applied to the reach within the same subbasin, with the exception of those subbasins (CL2A, CL5, CL7, CL8, CL9, SP2, SP4, and SP5) where dry wells are extensively present. In those subbasins the overland flow from the impervious land segments was routed into the ground-water reservoir; and

(7) Outflows of a reach were added to the next reach downstream.

A schematic diagram of the network design for each basin model is given on figure 5 . 


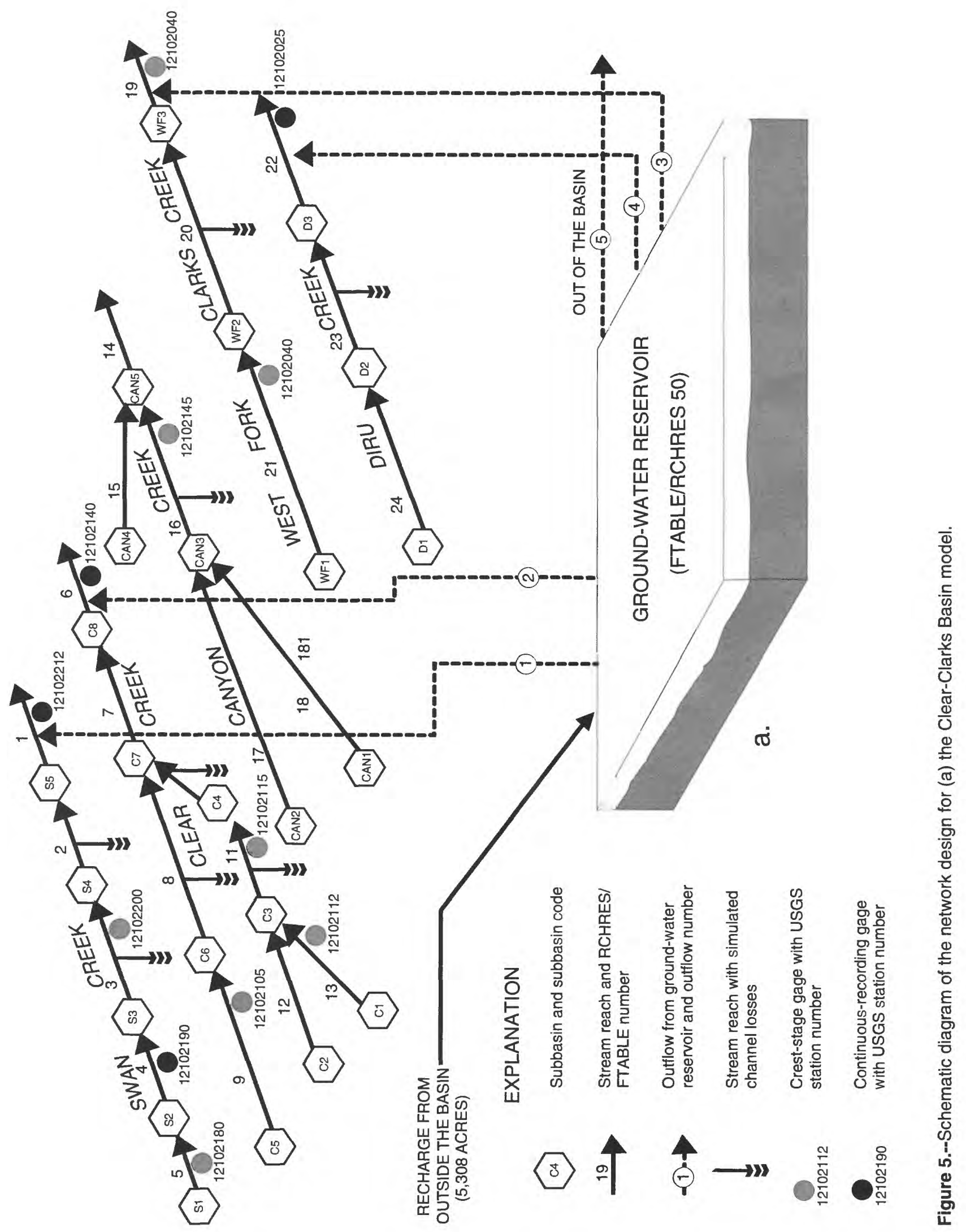




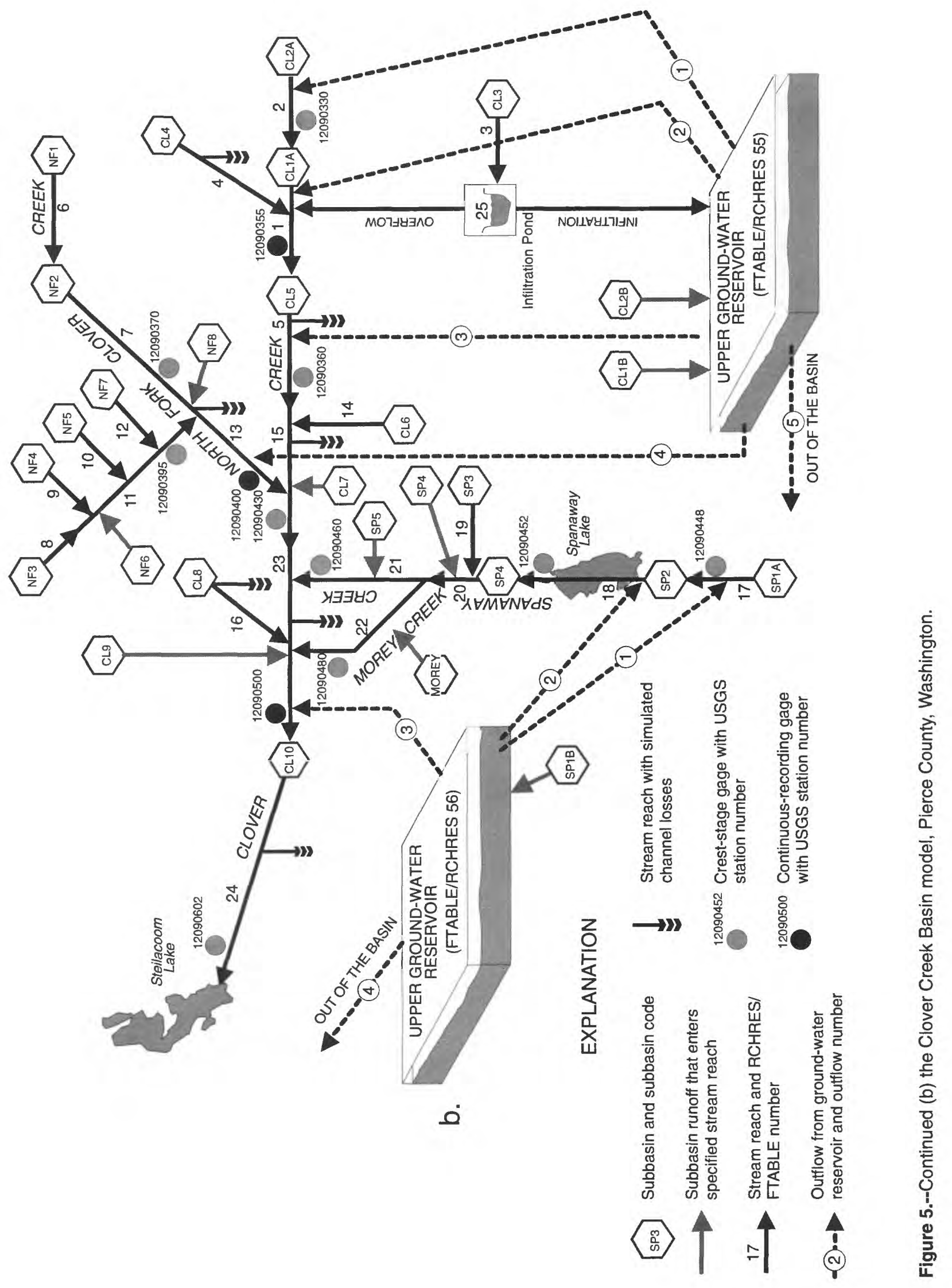




\section{Calibration of the Numerical Model}

Calibration of a numerical model is a trial-and-error process of adjusting process-related parameters or some other aspect of model construction, making model runs, and comparing simulated results with corresponding observed data. The procedure continues until results are within an acceptable range of error. As mentioned earlier, process-related parameters are difficult or impossible quantities to measure directly in the field. Some of the measurable physical attributes of the land and some guidelines of the conceptual model allow reasonable estimates of parameter values, but adjustments are generally needed for accurate simulations. Dinicola (1990) completed an extensive calibration process that produced a set of HSPF process-related parameters for land-segment types similar to those used in this study, for a similar conceptual model, and for similar stream basins in the Puget Sound Lowland. These parameters were used in the preliminary model runs for this study.

Data collection, catchment studies, and basin calibration were performed sequentially in order to progress from preliminary models that did not adequately simulate runoff at many sites in the study area to more accurate final basin models with unique calibration of runoff routing for each creek in the study area. Collection of observed data provided a measure of the ability of the models to simulate runoff accurately and provided direction for making adjustments. Catchment studies provided refinement of several process-related parameters by the calibration of HSPF numerical models for three catchment sites and one headwater basin where streamflows were continuously measured and little or no influence from ground water, channel storage, or channel losses affected runoff. Basin calibrations used process-related parameters calibrated from catchment studies and basin-specific adjustments affecting flows in the channel and ground-water system.

\section{Data Collection}

Stream discharge measurements were made at locations throughout the channel network of the study area over a 2-year period and provided observed data to compare with simulated data generated from the numerical models. A network of six rain gages was established in the study area and operated for the same 2-year period. The rainfall records provided water input to the basin models, PET was estimated and supplied to the models, and simulated runoff was generated and compared with observed runoff for the first year of streamflow data. The models were adjusted until a reasonable match between the observed and the simulated runoff records was obtained. Models calibrated using data collected during the first year were run for a second year, and simulated discharges were compared with streamflows observed during the second year. Differences between observed and simulated data in the second year offered a measure of assurance that the model would continue to simulate the hydrology of the basin accurately after the calibration period.

Table 4 lists all stream-gaging and rain-gage sites established and operated for this study. Gaging sites for the Clear and Clarks Creek Basins were operated for the 1990 and 1991 water years, and gaging sites for the Clover Creek Basin were operated for the 1991 and 1992 water years. Several gages in the Clover Creek Basin were installed late and did not have complete data for the 1991 water year. Figure 3 shows the location of the gages. The 10 continuous-recording stream-gage sites consisted of 5or 6-inch diameter wells open to the streams. Within a metal kutch on top of the wells, a float and potentiometer assembly connected to a data logger recorded stream stage every 15 minutes. The 15 -minute stage record computed a continuous stream-discharge record based on a stage-discharge relationship (rating curve) developed from monthly stream-discharge measurements. To supplement the continuous discharge record sites, 18 crest-stage gages were installed in the study area. These gages consisted of a 2 -inch pipe open to the stream. Inside the pipe, a long metal rod was positioned at a fixed height; bits of cork that floated on the water surface stuck to the rod and could be viewed when the rod was raised out of the pipe. The cork recorded the peak stage of the creek between visits to the site. The crest-stage gage was generally located upstream of a culvert. At most of the sites, a survey of the hydraulic features of the culvert was made, and the flow associated with the peak stage recorded by the crest-stage gage was computed indirectly. Discharge measurements at lower stages were made to verify the computations of peak flow. At crest-stage gages in the Clover Creek Basin, staff gages were included at the sites, discharge measurements were made periodically to establish a stage-discharge relationship, and observation of the stages at times other than peak flows provided additional stream discharge data. At two sites-Morey Creek and Clover Creek below 138th Street South-observers provided daily observations of stage. 
Table 4.--Streamflow and rainfall gaging site names, locations, station numbers, and period of record, Pierce County, Washington

\begin{tabular}{|c|c|c|c|c|}
\hline Station number & Station name & Latitude and longitude & Period o & f record \\
\hline \multicolumn{5}{|c|}{$\underline{\text { Continuous-recording streamflow gages }}$} \\
\hline 12090340 & $\begin{array}{l}\text { Unnamed Tributary to Clover Creek at } \\
\text { Bingham Avenue East near Parkland }\end{array}$ & $47^{\circ} 07^{\prime} 33^{\prime \prime} 122^{\circ} 22^{\prime} 00^{\prime \prime}$ & $10-90-$ & $09-92$ \\
\hline 12090355 & $\begin{array}{l}\text { Clover Creek at 25th Avenue East } \\
\text { near Parkland }\end{array}$ & $47^{\circ} 07^{\prime} 40^{\prime \prime} 122^{\circ} 23^{\prime} 43^{\prime \prime}$ & $10-90-$ & $09-92$ \\
\hline 12090365 & $\begin{array}{l}\text { Unnamed Tributary to North Fork } \\
\text { Clover Creek at Waller Road East } \\
\text { near Parkland }\end{array}$ & $47^{\circ} 08^{\prime} 02^{\prime \prime} 122^{\circ} 23^{\prime} 16^{\prime \prime}$ & $10-90-$ & $09-92$ \\
\hline 12090380 & $\begin{array}{l}\text { Unnamed Tributary to North Fork } \\
\text { Clover Creek at } 99 \text { th Avenue East } \\
\text { near Tacoma }\end{array}$ & $47^{\circ} 10^{\prime} 03^{\prime \prime} 122^{\circ} 24^{\prime} 39^{\prime \prime}$ & $10-90-$ & $09-92$ \\
\hline 12090400 & North Fork Clover Creek near Parkland & $47^{\circ} 08^{\prime} 05^{\prime \prime} 122^{\circ} 24^{\prime} 50^{\prime \prime}$ & $11-90-$ & $09-92$ \\
\hline 12090500 & Clover Creek near Tillicum & $47^{\circ} 08^{\prime} 40^{\prime \prime} 122^{\circ} 30^{\prime} 10^{\prime \prime}$ & $10-90-$ & $09-92$ \\
\hline 12102025 & $\begin{array}{l}\text { Diru Creek below Hatchery and } \\
\text { Pioneer Way near Tacoma }\end{array}$ & $47^{\circ} 11^{\prime} 35^{\prime \prime} 122^{\circ} 20^{\prime} 12^{\prime \prime}$ & $10-89-$ & $09-91$ \\
\hline 12102140 & $\begin{array}{l}\text { Clear Creek at Pioneer Way below } \\
\text { Fish Hatchery near Tacoma }\end{array}$ & $47^{\circ} 13^{\prime} 10^{\prime \prime} 122^{\circ} 22^{\prime} 25^{\prime \prime}$ & $10-89-$ & $09-91$ \\
\hline 12102190 & $\begin{array}{l}\text { Swan Creek at 80th Street East } \\
\text { near Tacoma }\end{array}$ & $47^{\circ} 11^{\prime} 05^{\prime \prime} 122^{\circ} 23^{\prime} 33^{\prime \prime}$ & $10-89-$ & $09-91$ \\
\hline 12102212 & Swan Creek at Pioneer Way near Tacoma & $47^{\circ} 13^{\prime} 43^{\prime \prime} 122^{\circ} 23^{\prime} 26^{\prime \prime}$ & $10-89-$ & $09-91$ \\
\hline \multicolumn{5}{|c|}{$\underline{\text { Crest-stage gages }}$} \\
\hline 12090330 & $\begin{array}{l}\text { Clover Creek at Military Road } \\
\text { near Spanaway }\end{array}$ & $47^{\circ} 06^{\prime} 17^{\prime \prime} 122^{\circ} 22^{\prime} 32^{\prime \prime}$ & $10-90-$ & $09-92$ \\
\hline 12090360 & $\begin{array}{l}\text { Clover Creek below 138th Street South } \\
\text { near Parkland }\end{array}$ & $47^{\circ} 07^{\prime} 56^{\prime \prime} 122^{\circ} 25^{\prime} 33^{\prime \prime}$ & $01-91-$ & $09-92$ \\
\hline 12090370 & $\begin{array}{l}\text { North Fork Clover Creek at Brookdale } \\
\text { Road near Parkland }\end{array}$ & $47^{\circ} 07^{\prime} 58^{\prime \prime} 122^{\circ} 24^{\prime} 06^{\prime \prime}$ & $11-90-$ & $09-92$ \\
\hline 12090395 & $\begin{array}{l}\text { Unnamed Tributary to North Fork } \\
\text { Clover Creek at Brookdale Road } \\
\text { near Parkland }\end{array}$ & $47^{\circ} 08^{\prime} 05^{\prime \prime} 122^{\circ} 24^{\prime} 28^{\prime \prime}$ & $10-90-$ & $09-92$ \\
\hline 12090430 & $\begin{array}{l}\text { Clover Creek at } 17 \text { th Avenue South } \\
\text { near Parkland }\end{array}$ & $47^{\circ} 08^{\prime} 35^{\prime \prime} 122^{\circ} 27^{\prime} 28^{\prime \prime}$ & $11-90$ & $09-92$ \\
\hline 12090448 & $\begin{array}{l}\text { Spanaway Creek at Spanaway Loop } \\
\text { Road near Spanaway }\end{array}$ & $47^{\circ} 06^{\prime} 03^{\prime \prime} 122^{\circ} 26^{\prime} 55^{\prime \prime}$ & $01-91-$ & $09-92$ \\
\hline 12090452 & $\begin{array}{l}\text { Spanaway Creek at Spanaway Lake } \\
\text { Outlet near Spanaway }\end{array}$ & $47^{\circ} 07^{\prime} 21^{\prime \prime} 122^{\circ} 26^{\prime} 43^{\prime \prime}$ & $10-90-$ & $09-92$ \\
\hline 12090460 & $\begin{array}{l}\text { Spanaway Creek at Tule Lake Outlet } \\
\text { near Parkland }\end{array}$ & $47^{\circ} 08^{\prime} 24^{\prime \prime} 122^{\circ} 27^{\prime} 17^{\prime \prime}$ & 03-91 - & $09-92$ \\
\hline
\end{tabular}


Table 4.--Streamflow and rainfall gaging site names, locations, station numbers, and period of record, Pierce County, Washington--Cont.

\begin{tabular}{|c|c|c|c|c|}
\hline Station number & Station name & Latitude and longitude & \multicolumn{2}{|c|}{ Period of record } \\
\hline \multicolumn{5}{|c|}{$\underline{\text { Crest-stage gages--Continued }}$} \\
\hline 12090480 & $\begin{array}{l}\text { Morey Creek above McChord Air } \\
\text { Force Base near Parkland }\end{array}$ & $47^{\circ} 07^{\prime} 48^{\prime \prime} 122^{\circ} 27^{\prime} 43^{\prime \prime}$ & $02-91-$ & 09-92 \\
\hline 12090602 & $\begin{array}{l}\text { Clover Creek at Gravelly Lake Drive } \\
\text { near Tacoma }\end{array}$ & $47^{\circ} 09^{\prime} 22^{\prime \prime} 122^{\circ} 31^{\prime} 18^{\prime \prime}$ & $01-91-$ & $09-92$ \\
\hline 12102040 & $\begin{array}{l}\text { West Fork Clarks Creek at 104th } \\
\text { Street East near Puyallup }\end{array}$ & $47^{\circ} 09^{\prime} 43^{\prime \prime} 122^{\circ} 20^{\prime} 53^{\prime \prime}$ & $10-89-$ & 09-91 \\
\hline 12102050 & $\begin{array}{l}\text { Clarks Creek Tributary at Pioneer } \\
\text { Way near Puyallup }\end{array}$ & $47^{\circ} 11^{\prime} 46^{\prime \prime} 122^{\circ} 20^{\prime} 47^{\prime \prime}$ & $10-89-$ & 09-91 \\
\hline 12102105 & $\begin{array}{l}\text { West Fork Clear Creek at 84th } \\
\text { Street East near Tacoma }\end{array}$ & $47^{\circ} 10^{\prime} 52^{\prime \prime} 122^{\circ} 22^{\prime} 34^{\prime \prime}$ & $10-89-$ & 09-91 \\
\hline 12102112 & $\begin{array}{l}\text { East Fork Clear Creek at 100th } \\
\text { Street East near Tacoma }\end{array}$ & $47^{\circ} 09^{\prime} 59^{\prime \prime} 122^{\circ} 21^{\prime} 57^{\prime \prime}$ & $10-89-$ & 09-91 \\
\hline 12102115 & $\begin{array}{l}\text { East Fork Clear Creek at } 72 \mathrm{nd} \\
\text { Street East near Tacoma }\end{array}$ & $47^{\circ} 11 ' 30^{\prime \prime} 122^{\circ} 22^{\prime} 11^{\prime \prime}$ & $10-89-$ & $09-91$ \\
\hline 12102145 & $\begin{array}{l}\text { Canyon Creek at } 77 \text { th Street } \\
\text { East near Tacoma }\end{array}$ & $47^{\circ} 11^{\prime} 13^{\prime \prime} 122^{\circ} 21^{\prime} 15^{\prime \prime}$ & $10-89-$ & 09-91 \\
\hline 12102180 & $\begin{array}{l}\text { Swan Creek at 96th Street } \\
\text { East near Tacoma }\end{array}$ & $47^{\circ} 10^{\prime} 12^{\prime \prime} 122^{\circ} 23^{\prime} 33^{\prime \prime}$ & $10-89-$ & $09-91$ \\
\hline 12102200 & $\begin{array}{l}\text { Swan Creek at 72nd Street East } \\
\text { near Tacoma }\end{array}$ & $47^{\circ} 11^{\prime} 30^{\prime \prime} 122^{\circ} 23^{\prime} 35^{\prime \prime}$ & $10-89-$ & 09-91 \\
\hline \multicolumn{5}{|c|}{$\underline{\text { Rainfall gages }}$} \\
\hline 12090365 & Penman site at Cow Pasture & $47^{\circ} 08^{\prime} 02^{\prime \prime} 122^{\circ} 23^{\prime} 16^{\prime \prime}$ & $08-91-$ & $09-92$ \\
\hline 470253122232001 & $\begin{array}{l}\text { Elk Plan Precipitation Gage at } \\
\text { County Yard }\end{array}$ & $47^{\circ} 02^{\prime} 53^{\prime \prime} 122^{\circ} 23^{\prime} 20^{\prime \prime}$ & $05-91-$ & $09-92$ \\
\hline 470532122223901 & $\begin{array}{l}\text { Brown's Precipitation Gage at } \\
3810 \text { 180th Street }\end{array}$ & $47^{\circ} 05^{\prime} 32122^{\circ} 22^{\prime} 39^{\prime \prime}$ & $01-91-$ & $09-92$ \\
\hline 470711122263201 & $\begin{array}{l}\text { Spanaway Park Precipitation } \\
\text { Gage at Maintenance Shop }\end{array}$ & $47^{\circ} 07^{\prime} 11^{\prime \prime} 122^{\circ} 26^{\prime} 32^{\prime \prime}$ & $01-91-$ & $09-92$ \\
\hline 470948122211801 & $\begin{array}{l}\text { Canyon Road Precipitation } \\
\text { Gage at Len Nelson's House }\end{array}$ & $47^{\circ} 09^{\prime} 48^{\prime \prime} 122^{\circ} 21^{\prime} 18^{\prime \prime}$ & $10-89-$ & $09-92$ \\
\hline 471242122232201 & $\begin{array}{l}\text { Waller Road Precipitation Gage } \\
\text { at County Gravel Pit }\end{array}$ & $47^{\circ} 12^{\prime} 42^{\prime \prime} 122^{\circ} 23^{\prime} 22^{\prime \prime}$ & $10-89$ & $09-91$ \\
\hline
\end{tabular}


PET, in inches of water per day, was computed by two methods. Daily pan-evaporation data recorded at Puyallup 2 West Experimental Station, a National Weather Service site located one-half mile southeast of the stream gage on Diru Creek, were used when available. The data were adjusted by a pan coefficient of 0.75 (Farnsworth and Thompson, 1982) to represent PET. The data were collected during the growing season, generally May through September, and the station was discontinued during the remainder of the year. When pan-evaporation data were not available, PET was estimated by application of the Jensen-Haise equation (Jensen, 1973). Incident solar radiation, one of the variables in the Jensen-Haise equation, was computed as a function of the percent possible sunshine. Daily minimum and maximum temperatures, elevation, and latitude for the Puyallup 2 West Experimental Station site and percent possible sunshine recorded at the National Weather Service Seattle-Tacoma Airport site were used in the Jensen-Haise equation.

Several seepage runs were conducted during the period of data collection. Seepage runs are a series of discharge measurements made along a stream reach during a short time span when stream levels are relatively stable.

Seepage runs were important in identifying areas of channel losses to ground water or areas of increases in streamflow from ground-water flow. Table 5 displays the results of two seepage runs on Clover Creek, when specific conductance and water temperature were measured and chloride samples were collected to help identify sources of water. The differences between the specific conductance readings for the stations on the upper main stem of Clover Creek (above Clover Creek mile 6.3) and the Spanaway Creek stations (Spanaway Creek at Tule Lake outlet and Morey Creek) suggested that the sources for these creeks are different.

Six rain gages were installed for this project. Two were storage-type rain gages with float-potentiometer assemblies. The other four rain gages were tipping-bucket rain gages. Rainfall was recorded at 15-minute intervals. Occasional missing records and a portion of the 1991 water year not recorded by the Clover Creek rain gages were estimated from the record at the Canyon Road rain gage, which was the only gage that was operated throughout the entire data collection period of the study. To estimate the missing record, the percent difference between the cumulative total of available record of each gage and the comparable record at Canyon Road was determined. Then the estimated record for missing data at a particular station was computed by substituting available Canyon Road data adjusted by the percent difference. Brown's rain gage near Frederickson recorded the highest totals, recording 5.7 percent more rain than the Canyon Road gage for a comparable period of 600 days. Approximately 3 miles south of Brown's rain gage is the Elk Plain rain gage, which generally recorded the least quantity of rain. For a comparison period of 501 days, the Elk Plain gage recorded 6.7 percent less than the Canyon Road gage.

During the period from February 5, 1991, to April 15, 1992, 40 instantaneous volumetric soil-moisture measurements were made at seven locations on one of the catchments known as the "Cow Pasture." An eighth location was added July 18,1991 , and 40 additional measurements at the new location were made through September 29, 1992. Figure 6 shows the location of soil-moisture measurements at the catchment. The time-domain reflectometry (TDR) technique was used to measure soil moisture. In this technique, two or three pairs of vertical rods extending from the surface to depths between 1.0 and 4.9 feet were installed at each location. The pairs of rods served as wave guides to measure the dielectric constant of the soil column between the rods. The dielectric constant depends strongly on the water content of the soil. Field evaluations show that this technique compares well with water content values determined from gravimetric samples (Topp and Davis, 1985). The TDR technique allows measurements of soil moisture to be made quickly in the field with minimal disruption of the soil. Probes were left in place throughout the period of data collection. Next to each set of probes a shallow piezometer was installed to measure water levels when the soil above the hardpan was saturated. 
Table 5.--Results from two seepage runs on June 26, 1991, and April 21, 1992, showing gains and losses of water on the main stem of Clover Creek, Pierce County, Washington

$\left[\mathrm{ft}^{3} / \mathrm{s}\right.$, cubic feet per second; ${ }^{\circ} \mathrm{C}$, degrees Celsius; $\mu \mathrm{S} / \mathrm{cm}$, microsiemens per centimeter at $25^{\circ} \mathrm{C} ; \mathrm{mg} / \mathrm{L}$, milligrams per liter; --, gain or loss not applicable or data not collected]

\section{CHAMBER CREEK BASIN \\ Clover Creek Seepage Investigations}

A series of discharge measurements was made on June 26, 1991, and April 21, 1992, on Clover Creek and its main tributaries to study the gains and losses of water on the main stem of Clover Creek. The creek is 12.5 miles long, beginning as a spring 0.7 mile above the highest measurement site, station number 12090325, and ending at Steilacoom Lake 0.4 mile below the lowest measurement site, station number 12090602. Creek flows were stable during both seepage runs, with less than 0.03 inch of rain falling during the prior 3 days before either seepage run was made. The three tributaries, the North Fork of Clover Creek, Spanaway Creek, and Morey Creek, are considered a contribution to flow and not a gain. No diversions of flow are known. Indicated gains or losses may be substantially in error as affected by small inaccuracies in the open-channel measurements. 
Table 5.--Results from two seepage runs on June 26, 1991, and April 21, 1992, showing gains and losses of water on the main stem of Clover Creek, Pierce County, Washington--Continued

\begin{tabular}{|c|c|c|c|c|c|c|c|}
\hline $\begin{array}{l}\text { Clover } \\
\text { Creek } \\
\text { mile }\end{array}$ & Stream & Location & $\begin{array}{l}\text { Measured } \\
\text { discharge } \\
\left(\mathrm{ft}^{3} / \mathrm{s}\right)\end{array}$ & $\begin{array}{l}\text { Gain } \\
\text { or } \\
\text { loss }\end{array}$ & $\begin{array}{l}\text { Water } \\
\text { tempe- } \\
\text { rature } \\
\left({ }^{\circ} \mathrm{C}\right)\end{array}$ & $\begin{array}{l}\text { Specific } \\
\text { conduc- } \\
\text { tance } \\
(\mu \mathrm{S} / \mathrm{cm})\end{array}$ & $\begin{array}{l}\text { Chloride } \\
(\mathrm{Cl} \text {, in } \\
\mathrm{mg} / \mathrm{L})\end{array}$ \\
\hline
\end{tabular}

Measurements made June 26, 1991

11.8 Clover Creek NE1/4SW1/4 sec 30, T.19 N., R.4 E., $\quad 0.87 \quad--\quad 9.7 \quad 137 \quad 4.9$

at Tacoma Sportsmen Club rifle

range (12090325)

10.4 Clover Creek Crest-stage gaging station at Military

$\begin{array}{lllll}6.29 & +5.42 & 11.4 & 153 & 7.7\end{array}$

Road near Spanaway (12090330)

9.3 Clover Creek NE1/4SW1/4 sec 23, T.19 N., R.3 E.

at $152 \mathrm{nd}$ Street (12090335)

$\begin{array}{llll}18.8 & +12.5 & 12.2 & 150\end{array}$

6.9

8.2 Clover Creek Gaging station at 25th Avenue

East near Parkland (12090355)

$\begin{array}{lllll}15.5 & -3.3 & 13.7 & 148 & 6.7\end{array}$

7.4 Clover Creek NW1/4SW1/4 sec 48, T.19 N., R.3 E.

11.0

$-4.5$

at 12 th Avenue East below Brookdale

Golf Coarse near Spanaway (12090358)

6.5 Clover Creek Crest-stage gaging station below 138th

$\begin{array}{llll}0.13 & -10.9 & 16.6 & 140\end{array}$

6.7

Street South near Parkland (12090360)

6.3 Clover Creek Staff gage station at 136th Street South

0

$-0.13$

near Parkland (12090362)

6.2 North Fork SW1/4SE1/4 sec 41, T.19 N., R.3 E., Clover Creek 0.04 mile upstream of mouth.

4.6 Clover Creek Crest-stage gaging station at 17th Avenue

South near Parkland (12090430)

4.1 Spanaway Crest-stage gaging station at Tule Lake

$\begin{array}{llll}16.4 & -- & 17.2 & 117\end{array}$

6.1

Creek

outlet near Parkland, 0.60 mile upstream

of mouth (12090460)

3.4 Morey Creek Crest-stage gaging station above McChord

$--$

16.3

118

6.1

Air Force Base near Parkland, 0.61 mile

upstream of mouth (12090480)

1.6 Clover Creek Gaging station near Tillicum (12090500)

0.4 Clover Creek Crest-stage gaging station at Gravelly Lake 
Table 5.--Results from two seepage runs on June 26, 1991, and April 21, 1992, showing gains and losses of water on the main stem of Clover Creek, Pierce County, Washington--Continued

\begin{tabular}{lllllll}
\hline $\begin{array}{l}\text { Clover } \\
\text { Creek } \\
\text { mile }\end{array}$ & Stream & Measured & Gain & Water & Specific & \\
tempe- & conduc- & Chloride \\
& Location & discharge & or & rature & tance & $(\mathrm{Cl}$, in \\
$\left(\mathrm{ft}^{3} / \mathrm{s}\right)$ & loss & $\left({ }^{\circ} \mathrm{C}\right)$ & $(\mu \mathrm{S} / \mathrm{cm})$ & $\mathrm{mg} / \mathrm{L})$ \\
\hline
\end{tabular}

Measurements made April 21, 1992

$\begin{array}{lllllll}11.8 & \text { Clover Creek NE1/4SW1/4 sec 30, T.19 N., R.4 E., at } & 1.01 & - & 8.5 & 142 & 4.7\end{array}$

Tacoma Sportsmen Club rifle range

(12090325)

10.4 Clover Creek Crest-stage gaging station at Military Road near Spanaway (12090330)

$\begin{array}{lllll}6.3+5.3 & 10.0 \quad 149 & 6.6\end{array}$

9.3 Clover Creek NE1/4SW1/4 sec 23, T.19 N., R.3 E. at 152 nd Street (12090335)

$\begin{array}{lllll}15.6 & +9.3 & 10.3 & \mathrm{I} 55 & 6.3\end{array}$

8.2 Clover Creek Gaging station at 25th Avenue East near Parkland (12090355)

$\begin{array}{lllll}14.9 & -0.7 & 11.1 & 154 & 6.2\end{array}$

7.4 Clover Creek NW1/4SW1/4 sec 48, T.19 N., R.3 E. at 12th Avenue East below Brookdale Golf Coarse near Spanaway (12090358)

6.3 Clover Creek Staff gage station at 136th Street South near Parkland (12090362)

6.2 North Fork SW1/4SE1/4 sec 41, T.19 N., R.3 E., Clover Creek 0.04 mile upstream of mouth

4.6 Clover Creek Crest-stage gaging station at 17th Avenue South near Parkland (12090430)

Crest-stage gaging station at Tule Lake Creek outlet near Parkland, 0.60 mile upstream of mouth (12090460)

3.4 Morey Creek Crest-stage gaging station above McChord Air Force Base near Parkland, 0.61 mile upstream of mouth (12090480)

$\begin{array}{lllll}5.6 & - & 13.5 & 120 & 6.5\end{array}$

1.6 Clover Creek Gaging station near Tillicum (12090500)

$50+25$

$+25 \quad 115$

127

6.4

0.4 Clover Creek Crest-stage gaging station at Gravelly Lake Drive near Tacoma (12090602)

44

11.0

126

6.5

\footnotetext{
${ }^{1}$ Discharge was determined from gage-height reading and current rating.

${ }^{2}$ Measured at gaging station at North Fork of Clover Creek near Parkland, 0.7 mile upstream of mouth (12090400).
} 


\section{EXPLANATION}

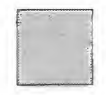

Forest-covered area

Altitude, in feet above

$-410-$

NGVD of 1929; Contour

interval 5 feet

Catchment boundary

...-... Subbasin boundaries

- Stream channels
Precipitation gage and USGS station number

Soil moisture sites T2.bot and site names

Continuous-recording streamgage and USGS station number

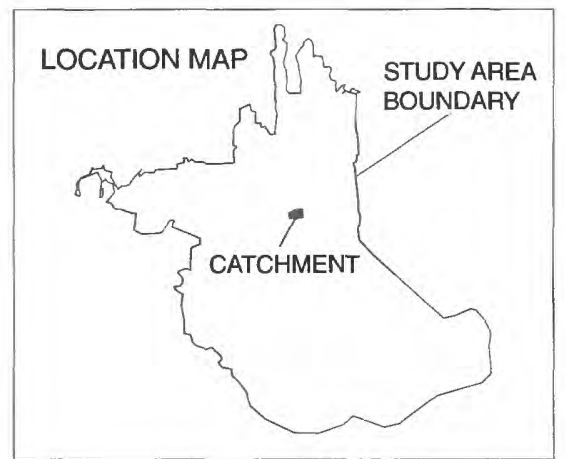

F Houses or other structures

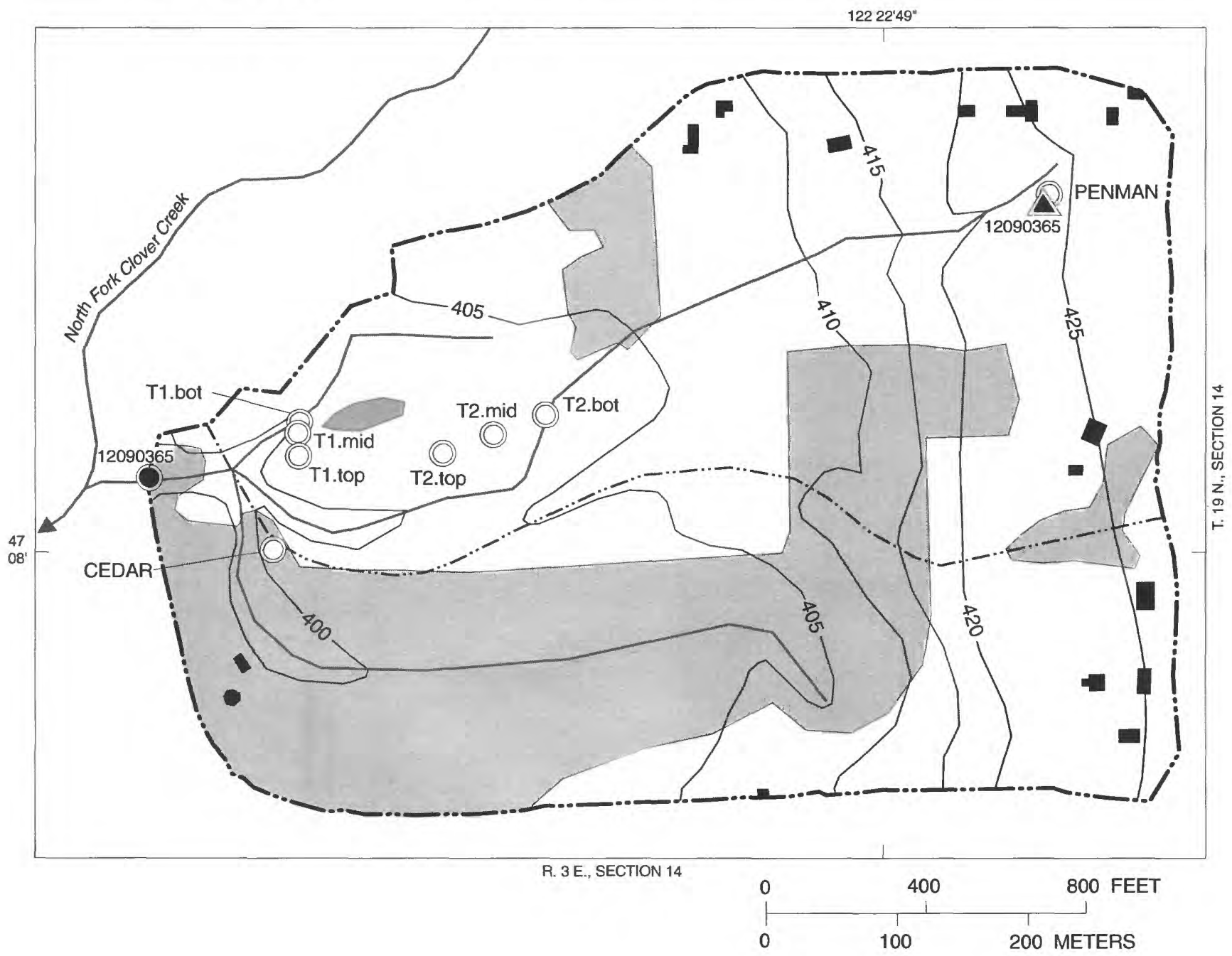

Figure 6.--The Cow Pasture Catchment, altitude contours, and the location of the soil moisture sites, rain gage,and streamflow gage. 


\section{Catchment Studies and the Rural Basin}

Streamflows at the mouth of three catchmentsnamed the Cow Pasture, the Suburban, and the MixedUse-were measured continuously for 2 complete water years (1991-92). Streamflows from a fourth basin, the Rural Basin, were also measured continuously for 2 water years (1990-91) and are included in this discussion. These catchments and the Rural Basin were used in calibration of the process-related parameters.

These catchments and the Rural Basin are located on till soils in the headwater areas of the study area. Groundwater and channel-loss processes that strongly influenced the timing and quantity of runoff at the downstream gaging stations did not substantially influence runoff from these basins. The catchments and the Rural Basin had predominately uniform soil, land-use, and slope characteristics, whereas the stream gages near the mouth of the larger basins measured runoff that integrated flow produced from many land-segments types. Therefore, the catchments and the Rural Basin provided a more controlled setting to gather insights to the hydrologic processes controlling runoff from hillslopes in till-mantled basins. The process-related parameters calibrated to runoff responses of the catchments and the Rural Basin, namely the parameters for flat land segments underlain by till, and the previously calibrated process-related parameters by Dinicola (1990) were used for the entire study area in the final calibrated basin models.

The distribution of land segments and the drainage area for each of the catchments and the Rural Basin are shown in table 2. The Rural Basin comprises the two uppermost subbasins on Swan Creek, subbasins S1 and S2 (at the beginning of table 2), that are gaged by station 12102190. Although it is too big to be considered a catchment ( 2.36 square miles), it is similar to the catchments in that it has uniform land uses and no evidence of groundwater contributions to streamflows or channel losses. Simulations of the Rural Basin provided additional insights to the calibration of process-related parameters. The catchments are all found in the Clover Creek drainage basin. All the catchments and the Rural Basin are on flat, till soils, with amounts of effective impervious area varying from 0 to 23.2 percent of the total area. Because the observed record at the Mixed-Use and Suburban Catchments was less accurate than the record at the Cow Pasture and the Rural Basin, the Mixed-Use and Suburban Catchments were not used to calibrate the parameters. However, they did provide a degree of validation of the parameters and of the ability of the model to provide reasonably accurate simulation of runoff from these types of basins.
Land use on the Cow Pasture Catchment is approximately one-half low-intensity cow pasture and one-third forest land, and the remainder is scattered, large-acreage, single-family housing along the perimeter. Much of the calibration of process-related parameters for flat-till land segments focused on this catchment and the Rural Basin. Streamflow records were rated fair at the cow pasture, except the largest peak flows, which are rated poor because they had to be estimated. The gage record during the largest peaks was influenced by water overflowing from a nearby creek.

The Rural Basin is typical of the rural landscape on the flat, glacial-till soils that characterize most of the headwater regions of Clear, Clarks, and the North Fork Clover Creek drainage basins. Encroachment of the urban landscape is evident in the western margins of the basin, but the amount of effective impervious area is still relatively low (estimated at 7.8 percent of the basin). Observations that the stream at the mouth of the basin is intermittent indicate that the streamflow is not influenced by any regional ground-water inflow. The basin is located in the headwaters above the regional water table that provides continuous flow in the stream further downstream. Seepage runs between the upstream site, station 12102180, and the downstream site, station 12102190 , indicate that no channel losses are occurring. There was no evidence of significant floodwater storage features such as detention ponds or large swampy areas that could influence the storm hydrograph and that would be difficult to characterize in the flow-routing part of the numerical model. Streamflow records at the mouth of this basin are generally more reliable than streamflow records at the catchment gaging sites. Calibration of this basin model was done at the same time as calibration of the Cow Pasture model.

The Mixed-Use Catchment represents a landscape in transition between a rural setting and an urban setting. The catchment contains the full range of land uses from low density areas to industrial areas. A railroad crosses diagonally through the catchment, partly obstructing natural flow across the railroad embankment. The channel upstream from the railroad grade is extremely flatter and wide. The area is swampy in some locations and drains slowly. The channel below the railroad grade is more defined and thick brush grows along its banks.

The Suburban Catchment is small (9.5 acres), and one well-established suburban development defines all of the land use. It has 2.8 residential houses per acre, and it contains the highest estimated percentage of effective impervious area of all the catchments. Channels consist of open roadside ditches, and the streamflow gage measured flow 
immediately downstream of the intersection of the two main road ditches. The observed streamflow record at this site was rated poor because of variable backwater conditions at the site and the small quantities of measured discharges.

The preliminary HSPF numerical model was constructed, and the preliminary calibration for the Cow Pasture Catchment and the Rural Basin was conducted according to the guidelines published by Dinicola (1990). Preliminary calibrations at both the Cow Pasture and the Rural Basin were generally satisfactory, but some trends in the errors were noted. During the largest storms, the models tended to simulate storm hydrographs with steeper rising limbs than observed, to oversimulate runoff during the fall storms (simulated discharge was greater than observed discharge), to undersimulate winter and spring medium to low flows (simulated discharge was less than observed discharge), and to undersimulate total runoff (figs. 7, 9).

Preliminary models were refined by small adjustments to routing and to selected parameters to produce slightly better final calibrated models. The flashy storm hydrographs seemed to indicate that the preliminary simulated storm hydrograph produced too much overland flow. By routing more storm-water flow through interflow to the channel and less by overland flow, the final calibrated model produces a less flashy storm hydrograph (fig 8,9). This adjustment was achieved in the numerical model by increasing the value of the INTFW process-related parameter (from the reservoir analogy of the numerical model, INTFW is a valve that lets water into the interflow reservoir) and by decreasing the IRC parameter (the outlet valve for the interflow reservoir), thereby extending the recession limb of the storm hydrograph. In preliminary numerical models, outflow from active ground-water storage was routed to the basin outlet as ground-water discharge rather than routed into the channel. In the final calibrated models, outflows from active ground-water storage are routed to the channel, and the outflows are intended to simulate relatively slow-moving soil moisture discharge to the channel. The final models use an additional flow path not used by the preliminary models to represent recharge through the till that may eventually discharge to the basin outlet. This addition was accomplished by changing the DEEPFR process-related parameter from the value of 0.0 that was used in the preliminary models to 0.25 in the final models, which allows onefourth of all the water available to the active ground-water reservoir to be diverted to the deep ground-water reservoir. (In the basin models, this water is recharge to the simulated ground-water reservoirs). The remaining water in the active ground-water flow path helps maintain streamflows between large storms and during spring and early summer. The parameter AGWRC was adjusted until simulated low flows reasonably fitted the observed low flows. The active ground-water and interflow flow paths were used in the final calibrated models to give the numerical models the flexibility to simulate the movement of water in the soil zone; this routing is compatible with the conceptual model in representing the variable lag between the time when water enters the soil and when it enters the channel. The interflow pathway in the final calibrated model represents the relatively quick flow rates of subsurface flow near the channel, and the active ground-water pathway represents delayed subsurface flow from parts of the land segments located some distance away from a stream channel. The deep ground-water pathway represents recharge through the glacial till into the regional ground-water system.

In the final basin models, two distinctions of recharge or ground-water discharge were made for runoff from the land segments. In till- and saturated-soil land segments, AGWO represented slow-moving shallow soil water, and in outwash-soil land segments it represented ground-water recharge to local aquifers that discharged to the nearby channel reach. Recharge to regional aquifers was simulated with the deep or inactive ground-water inflow (IGWI) that recharged the simulated ground-water reservoir and generally discharged at a distant channel reach. In till-soil land segments the IGWI represented recharge to a regional aquifer, and in outwash-soil land segments no recharge to regional ground-water aquifers was simulated $(\mathrm{IGWI}=0.0$ ). Exceptions to these rules are for subbasins in the remote southern sections of the Clover Creek Basin, subbasins CL1B, CL2B, and SP1B, where no nearby streams existed and all runoff from the land segments recharged the simulated ground-water reservoirs.

In the preliminary models and especially in the final models, most of simulated runoff to the channel for till and saturated land segments travels through the soil. In order to decrease storm runoff simulated during the fall season, the LZSN parameter was increased in the final models to increase the size of the lower zone reservoir; thus more water is routed through the soil zone, and the simulated storm hydrographs are less responsive to precipitation inputs until the lower zone reservoir begins to fill to capacity. In the final models, generally only 2 percent or less of the total runoff from the till land segments is overland flow; the remainder passes through the soil zone before reaching the channel or the ground-water reservoir. 


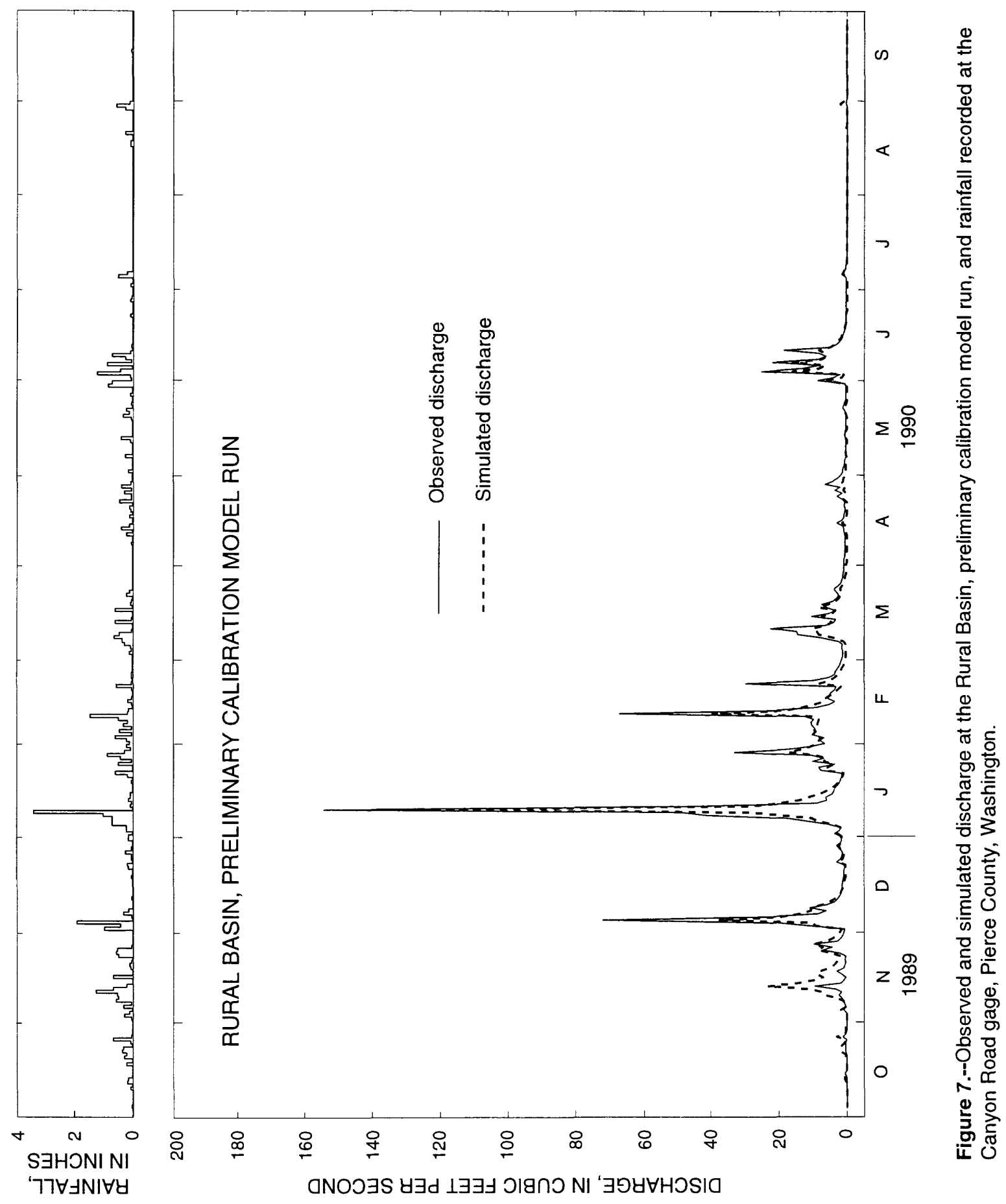




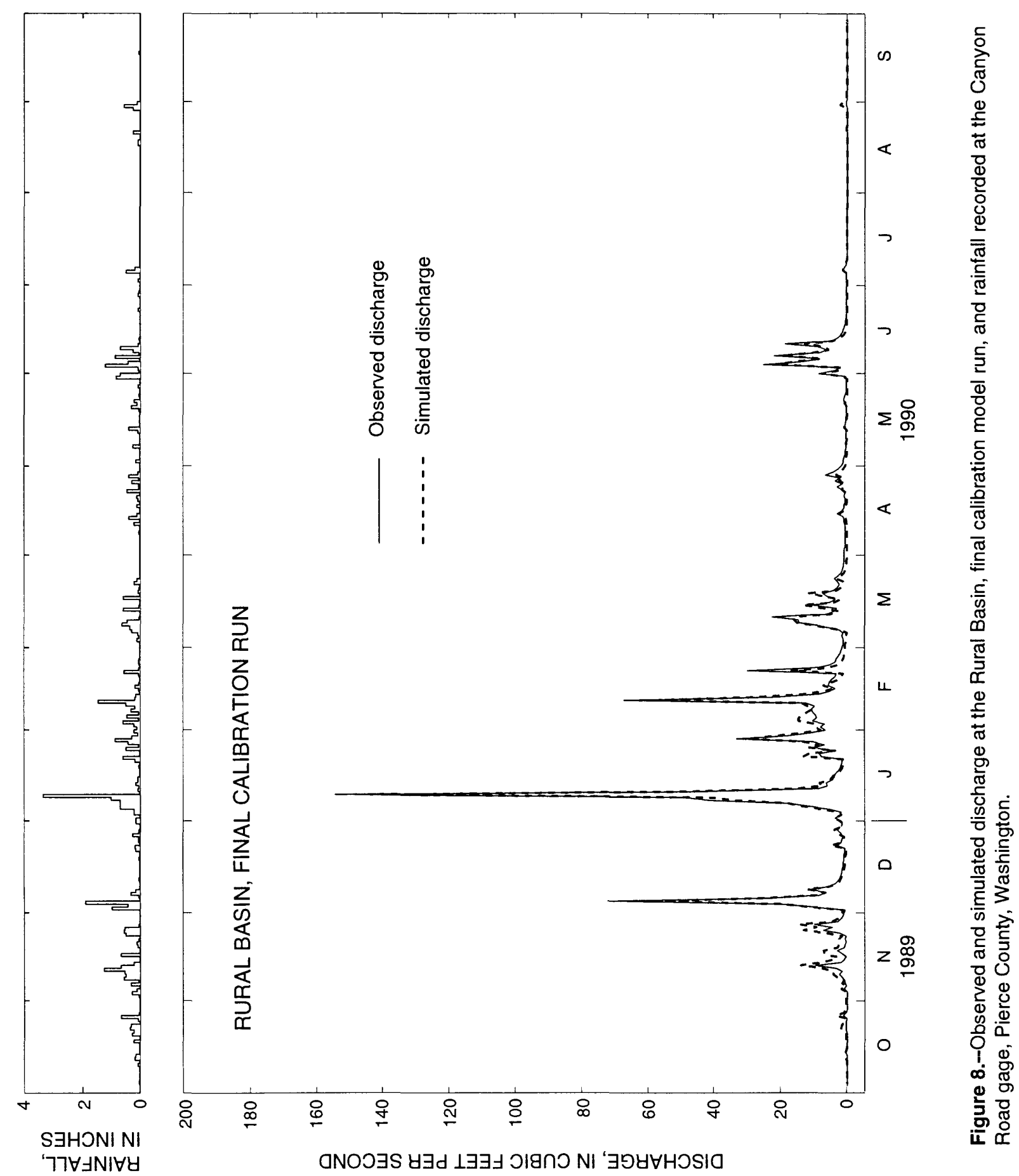



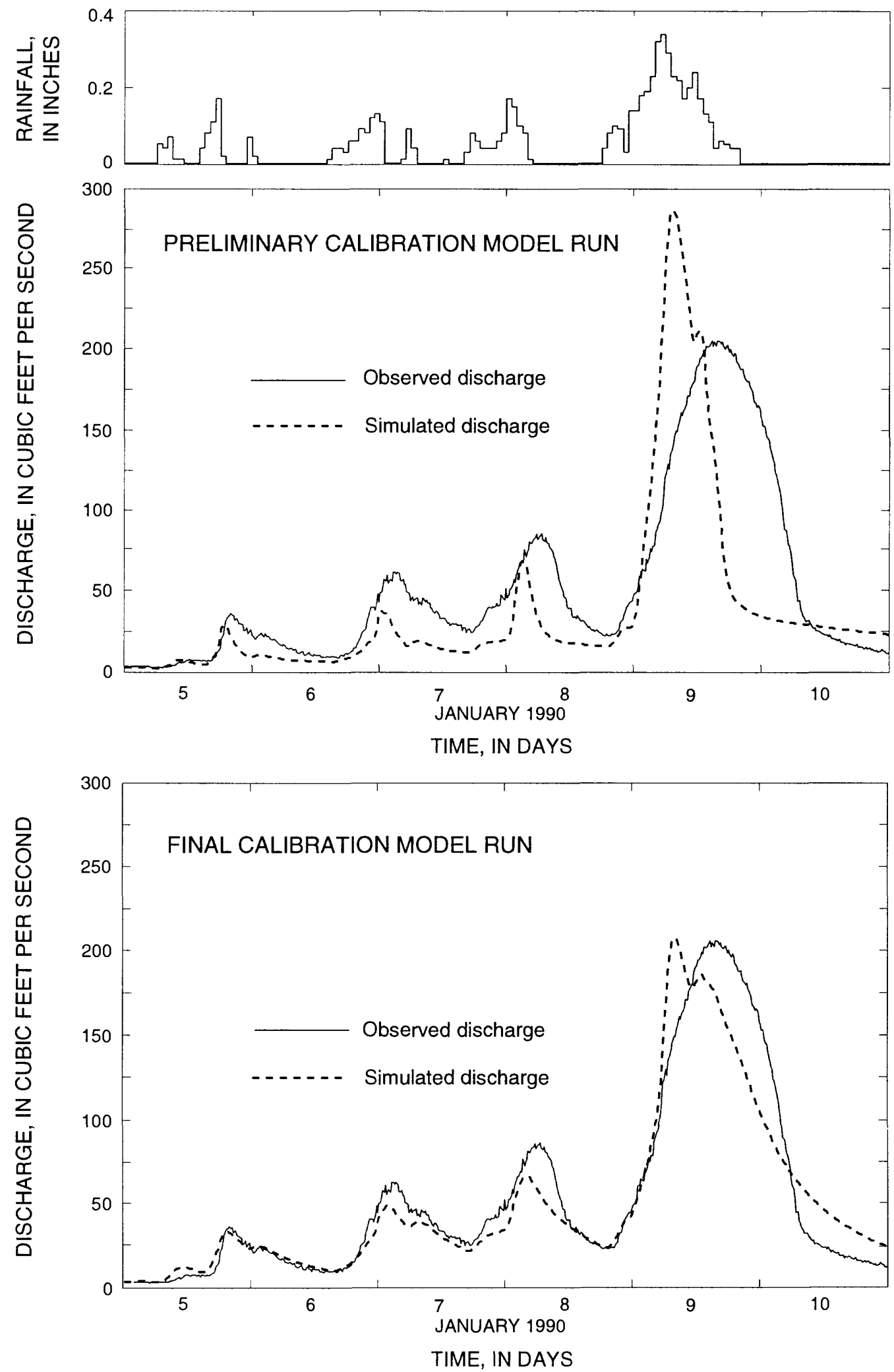

Figure 9.--Storm hydrographs of observed discharge with the preliminary and final calibrated simulations for the Rural Basin and rainfall at the Canyon Road gage, Pierce County, Washington. 
The simulated soil moisture was compared with observed soil moisture to provide some validation that the model correctly simulates the quantities of moisture stored in the soil reservoirs. Soil-moisture measurement sites were located at the bottom, midpoint, and top of two transects along slopes from the channel to the ridge top (sites T1.bot, T1.mid, T1.top, T2.bot, T2.mid, and T2.top on fig. 6). The two other soil moisture sites were the Cedar site, located in a grove of cedar trees, and the Penman site, located at the weather station in a flat pasture in the upper part of the catchment. All the sites were located on a cow pasture and were on till-grass-flat land segments, except the Cedar site, which was on a tillforest-flat land segment. The T1.bot site was in a small marshy area in the channel that closely represented a saturated land segment that remained saturated about one-third longer than the other sites, and for this reason, the observed data from T1.bot were used for comparison with simulated soil moisture for saturated land segments.

Observed soil moisture was measured with pairs of probes at two or three depths by the TDR method; the results represented average volume percentage of water in the soil from the surface to the depth of the probes. The measured soil moisture represents total water in the soil, but part of the total water is the moisture below the wilting point of the soil that is not available for runoff or ET. On the other hand, soil moisture simulated in the model by storage in the upper, lower, and active ground-water reservoirs is all available to the model for runoff or ET and thus represents only that part of the physical soil moisture above the wilting point. Therefore, the total measured soil moisture had to be corrected by subtraction of moisture below the wilting point so that comparisons could be made. The wilting point of the soil was estimated to be the lowest soil measurement made during the data collection period. The plots of soil moisture over time for the T1.bot and T2.bot sites did not show any sustained low moisture reading that indicated the soil had reached the wilting point. Therefore, the wilting point for the soil at these two sites was assumed to be the value estimated for nearby sites. Except for the T1.bot site, soil depths were measured by the maximum depth that the piezometers could be driven into the ground because the till-soil interface at the base of the soil layer obstructed further penetration. The soil depths measured in this fashion ranged from 2.65 to 3.65 feet. At T1.bot where the wet interface allowed the piezometer to penetrate, soil depth was estimated at 3.2 feet, the average of all the other soil depths. The available soil moisture in inches, $A S M$, at each of the sites was estimated using the following formula:

$$
A S M=(S M \%-W P \%) \times S D \times 12,
$$

where $S M \%$ is the percentage of water by volume in the soil column measured by the longest pair of probes that does not penetrate the till, WP\% is the wilting point of the soil as a percentage of moisture by volume of soil, and $S D$ is the soil depth in feet.

In addition to the increase in the parameter LZSN to enlarge the simulated lower-zone reservoir, the AGWETP and the LZETP process-related parameters for the till and saturated land segments were also adjusted to influence the simulated rate of soil moisture depletion during the summer and more closely match observed available soil moisture. Observed available soil moisture shows a wide variation between sites. Simulated soil-moisture curves follow the general trend of the observed data, and final simulated moistures more closely match the trend than the initially simulated soil moistures (figs. 10 and 11).

Soil-moisture measurements also aided in calibration of the DEEPFR parameter for the saturated land segment. The saturated land segment is absent from the Cow Pasture, as determined from soil maps, and is poorly represented in the Rural Basin (14.7 percent). For this reason, gaged runoff from these two basins was not representative of the saturated land segment, and therefore, it was not reasonable to compute recharge from the annual water budget (recharge equals precipitation minus actual evapotranspiration minus runoff) in the same manner that it was computed for the till land segments. Recharge from the saturated land segment was estimated based on the assumption that recharge through the till is a function of the time that the soil above the till is saturated. Comparisons of piezometer and TDR data at different sites in the Cow Pasture showed that soil at the T1.bot site, the representative saturated soils site, was saturated approximately 33 percent of the time longer than the other soil moisture sites. The DEEPFR parameter for the saturated land segment was thus adjusted to produce approximately 33 percent more recharge than the till-grass-flat land segments. 


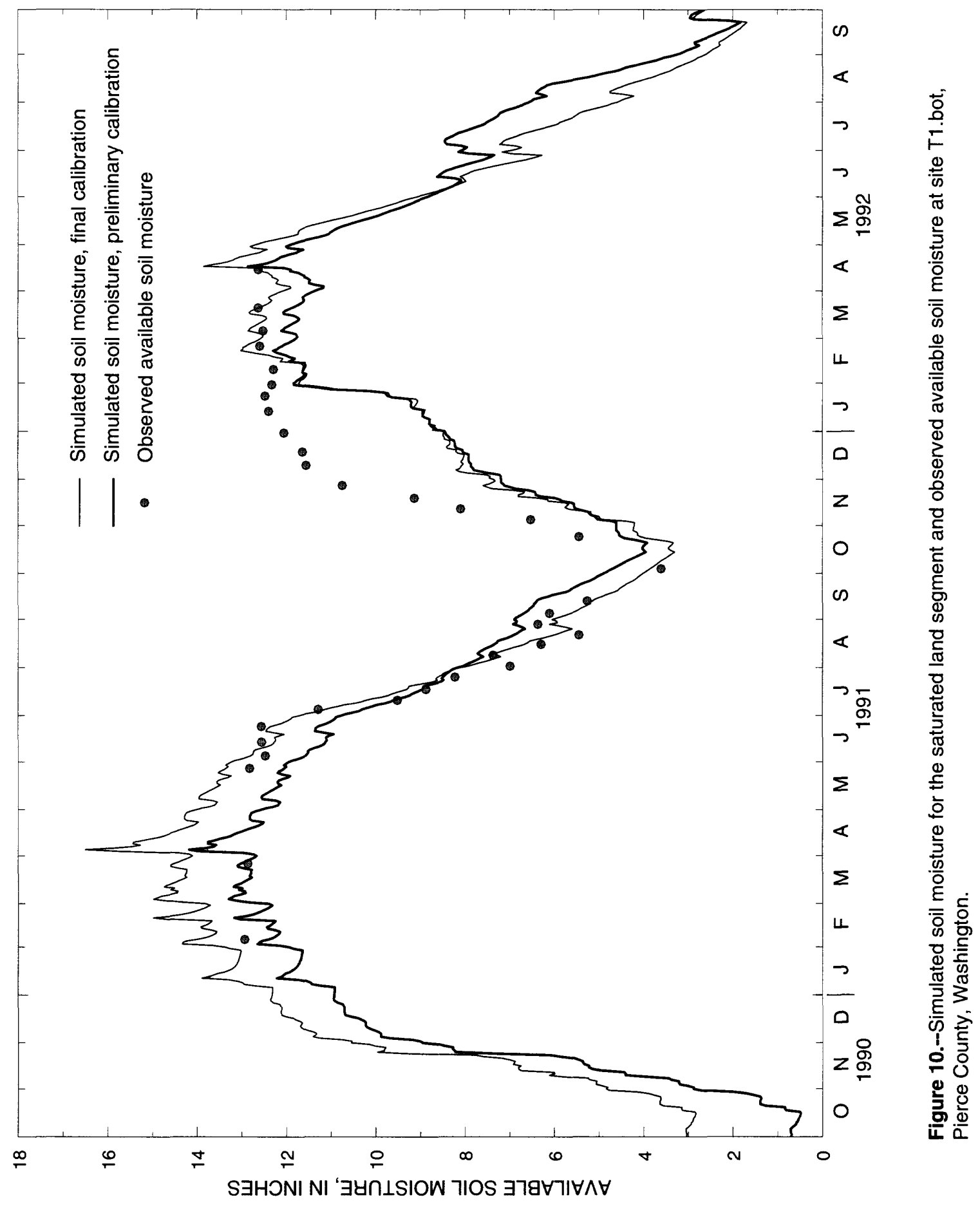




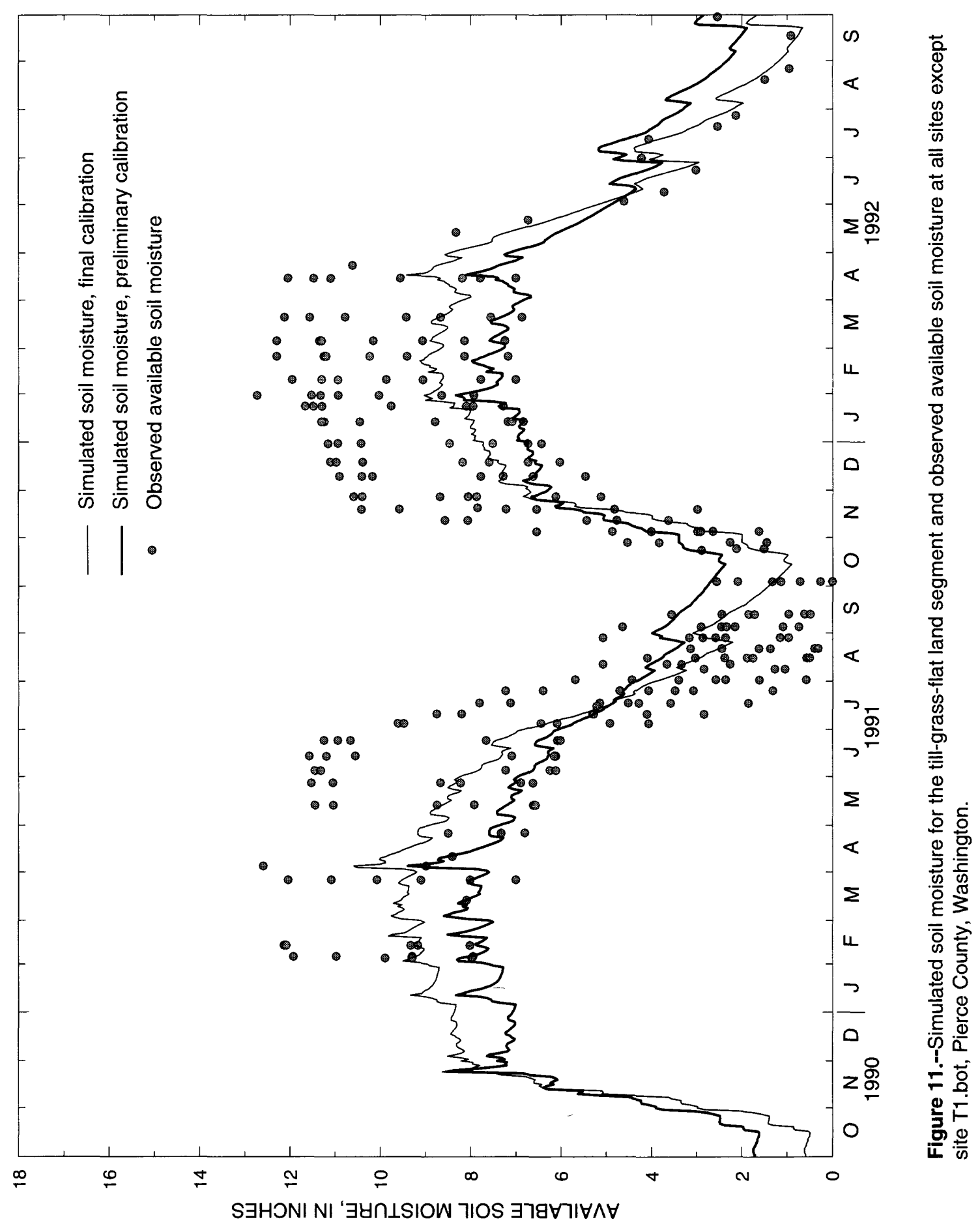


On the basis of calibration to the hydrograph shape of the observed discharge record, three process-related parameters-AGWRC, INTFW, and IRC-were changed from their preliminary values. AGWRC was changed from a value of 0.996 to 0.80 for all the till and saturated land segments. The original value was calibrated by Dinicola (1990) for controlling the simulated recession limb of base-flow contributions from ground-water discharge, a discharge representing a pathway through the till to a nearby or distant channel reach. In the final models, AGWRC controls the recession of soil-water discharge and had to be lowered to allow simulated streamflows at the Cow Pasture and the Rural Basin to go dry in the spring and early summer. Soil-water discharge represents a soil-surface pathway above the till that always discharges to a nearby channel reach. INTFW was raised to increase the portion of interflow from the water available for surface runoff or interflow and, thereby, to decrease the portion of overland flow. This adjustment resulted in a less flashy storm hydrograph in the final models. The IRC parameter affects the recession limb of the interflow hydrograph, and this parameter was lowered in the final models to match more closely the observed hydrograph immediately following peak discharges. In preliminary models, INTFW and IRC varied with slope of the till land segments. The parameters were changed for the mediumand steep-sloped land segments in proportion to changes made for the flat-sloped land segments. Few or no medium and steep land segments were found in the Cow Pasture or the Rural Basin to allow direct calibration of these parameters.

A final change to one of the preliminary processrelated parameters was to SLSUR, the average slope of the overland flow plane. Measurements of slope from the topographic map of the Cow Pasture showed gentle slopes that averaged about 0.01 . The slopes at the Cow Pasture typified the region in general and were less than the average of the flat-slope category ( 0.0 to 6.0 percent) used by the USDA for soil classification and by this study to determine till-flat land segments, so SLSUR for the till-flat land segments was changed from the preliminary model's value of 0.05 to 0.01 . The other two slope classes were approximate averages of the slope classes that appeared reasonable for the limited amount of medium- and steep-sloped land segments found in the study area, so they were not adjusted.
The calibration of the Cow Pasture and Rural Basin models produced a set of process-related parameters that govern simulation of runoff from the different land segments. The influence of the parameters can best be shown by how different parameters affect a storm hydrograph and how runoff is distributed between different possible simulated flow paths. A large storm in April 1991 provides an example of how four different land segments distribute runoff to the stream channel (figs. 12 and 13). Hydrographs of the till-grass-flat and till-forest-flat land segments have similar shapes, and both show a large percentage of total runoff as interflow (fig. 12). The major difference was the large quantity of surface runoff generated by the grass land segment compared to the small quantity of surface runoff in the forest land segment. Surface runoff from the grass land segment was only 5.7 percent of storm runoff over the duration of the storm (April 2-6), but was 50.3 percent of instantaneous flow at the peak on April 4. Active ground water (representing relatively slow-moving soil-moisture discharge) was also a small portion of total storm flow, but it was important in maintaining low flows between peak flows. By April 12, active ground water supplied all of the flow to the channel. Surface runoff was a large percentage of total runoff for the hydrograph of the saturated land segment (fig. 13). The April storm occurred late in the rainy season when soil moisture was high. Little infiltration could occur even during moderate rain intensities, and peak runoff had little lag time after the peak rain intensities. Peak runoff quickly fell as rainfall dropped off, and active ground water dominated the hydrograph as soil moisture slowly drained. There was little response by the outwash land segment to the rainstorm, although by April 15 it produced more runoff, almost entirely ground-water outflow, than any of the other three land segments combined. The outwash land segment produced peak discharge that was only 8.7 percent of the peak discharge from the till-grass-flat land segment and 12.2 percent of the peak discharge from the saturated land segment.

A list of calibrated process-related parameters is shown in table 6 . These parameters were used unchanged in both final basin models that simulated runoff for the entire study area. 

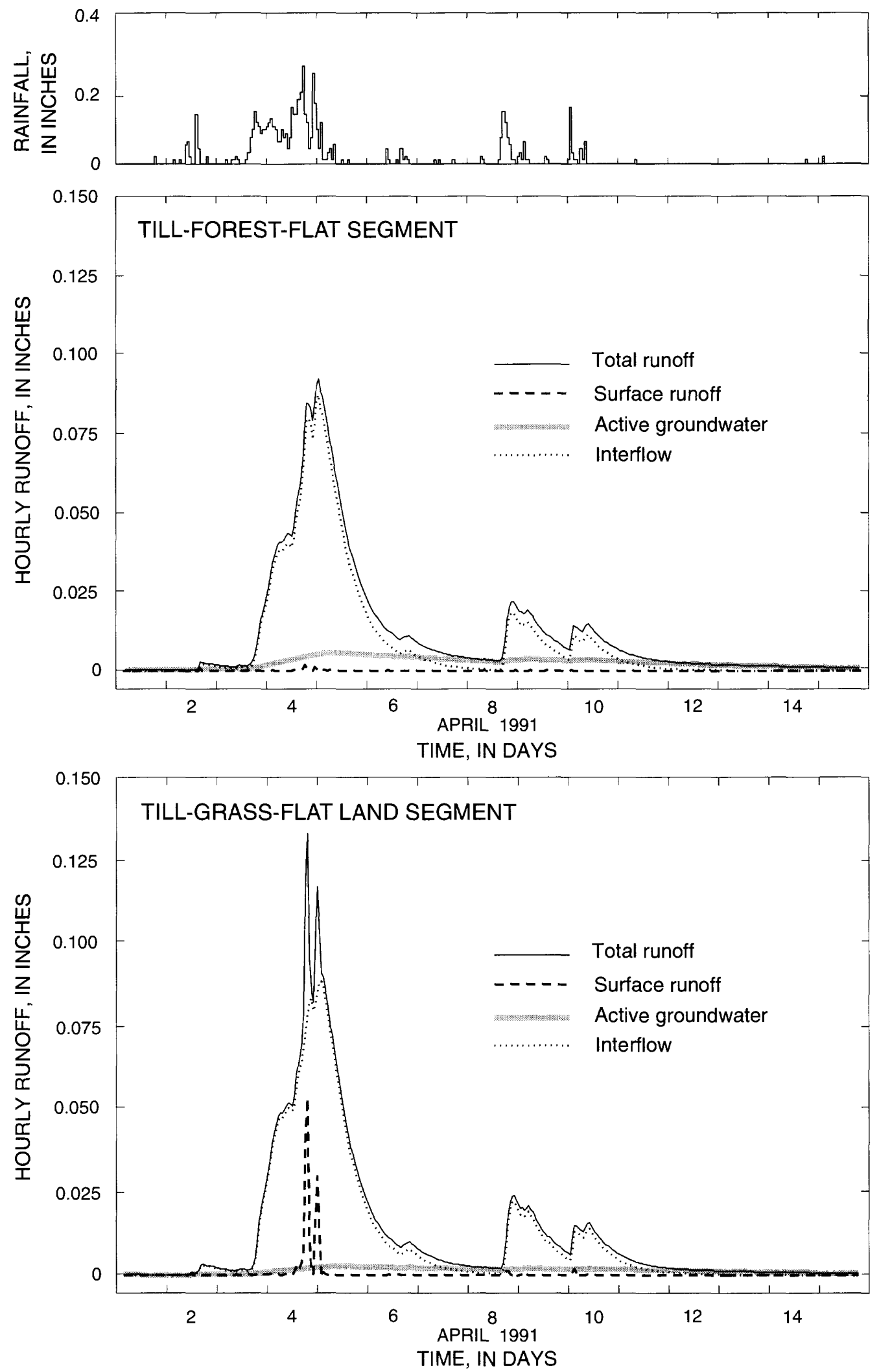

Figure 12.--Simulated storm runoff and various components of flow from till-forest-flat and till-grass-flat land segments and rainfall from the Canyon Road gage, Pierce County, Washington. 

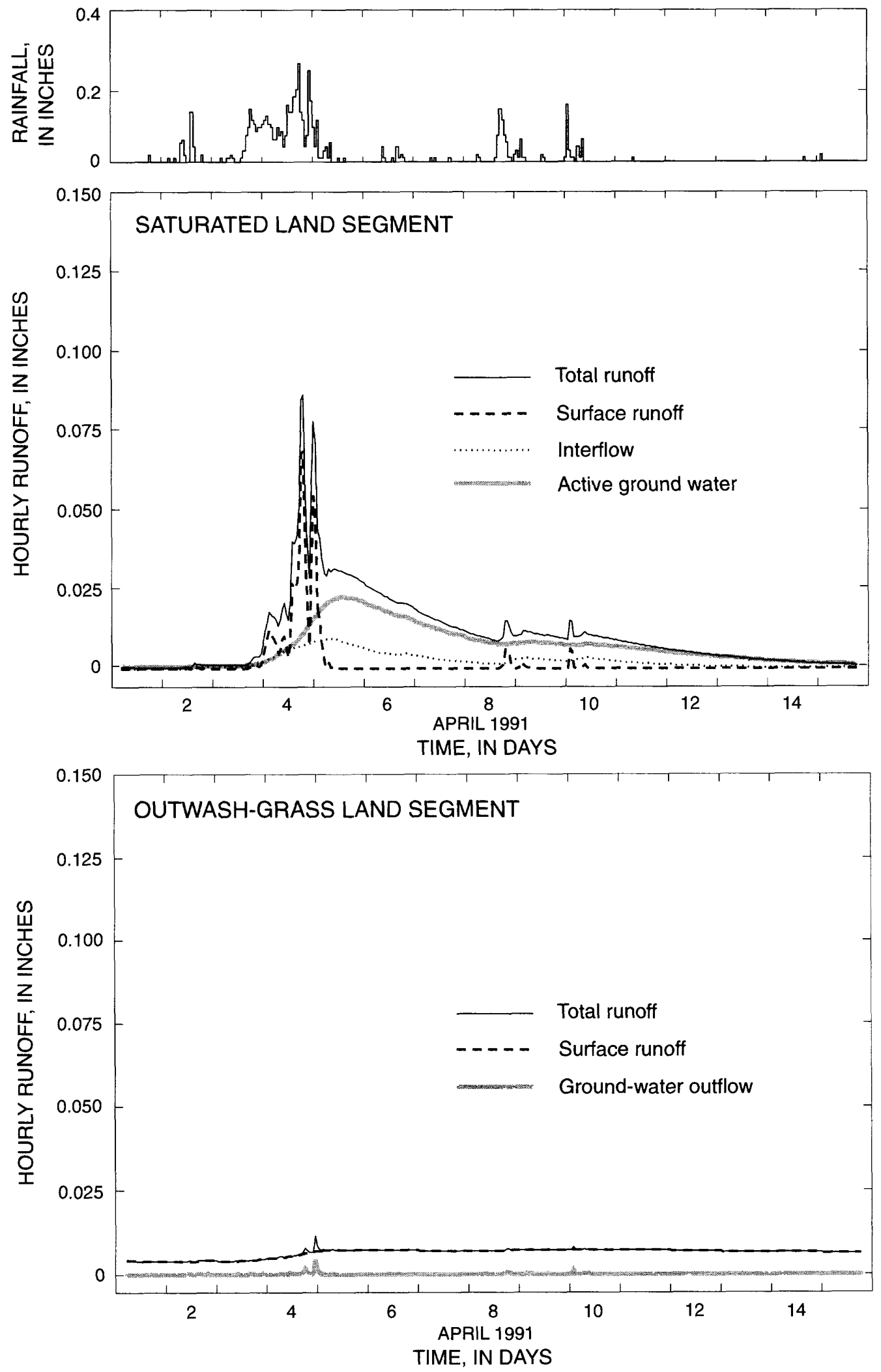

Figure 13.--Simulated storm runoff and various components of flow from saturated and outwash-grass land segments and rainfall from the Canyon Road gage, Pierce County, Washington. 
Table 6.--Calibrated process-related model parameters for each of the land segments, Pierce County, Washington

[Units are printed below parameter name; in., inch; in/hr, inches per hour; ft, feet; 1/in, 1/inch; n/a, not applicable; where units are not listed, the parameter has no units; EIA, effective impervious areas; TFF, till soils, forest cover, flat slopes; TFM, till soils, forest cover, moderate slopes; TFS, till soils, forest cover, steep slopes; TFG, till soils, grass cover, flat slopes; TGM, till soils, grass cover, moderate slopes; TGS, till soils, grass cover, steep slopes; OF, outwash soils, forest cover; OG, outwash soils, non-forest cover; SA, saturated soils, all covers]

\begin{tabular}{|c|c|c|c|c|c|c|c|c|c|}
\hline \multirow[b]{2}{*}{$\begin{array}{l}\text { Land } \\
\text { segment }\end{array}$} & \multicolumn{9}{|c|}{ Model parameter ${ }^{1}$} \\
\hline & $\begin{array}{l}\text { LZSN } \\
\text { (in.) }\end{array}$ & $\begin{array}{l}\text { INFILT } \\
(\mathrm{in} / \mathrm{hr})\end{array}$ & $\begin{array}{l}\text { LSUR } \\
(\mathrm{ft})\end{array}$ & SLSUR & $\begin{array}{l}\text { KVARY } \\
(1 / \text { in })\end{array}$ & $\begin{array}{l}\text { AGWRC } \\
\text { (1/day) }\end{array}$ & INFEXP & INFILD & BASETP \\
\hline EIA & $\mathrm{n} / \mathrm{a}$ & $\mathrm{n} / \mathrm{a}$ & 500 & 0.01 & $\mathrm{n} / \mathrm{a}$ & $\mathrm{n} / \mathrm{a}$ & $\mathrm{n} / \mathrm{a}$ & $\mathrm{n} / \mathrm{a}$ & $\mathrm{n} / \mathrm{a}$ \\
\hline TFF & 6.0 & 0.08 & 400 & 0.01 & 0.5 & 0.80 & 3.5 & 2.0 & 0.0 \\
\hline TFM & 6.0 & 0.08 & 400 & 0.10 & 0.5 & 0.80 & 2.0 & 2.0 & .0 \\
\hline TFS & 6.0 & 0.08 & 200 & 0.20 & 0.5 & 0.80 & 1.5 & 2.0 & .0 \\
\hline TGF & 6.0 & 0.03 & 400 & 0.01 & 0.5 & 0.80 & 3.5 & 2.0 & .0 \\
\hline TGM & 6.0 & 0.03 & 400 & 0.10 & 0.5 & 0.80 & 2.0 & 2.0 & .0 \\
\hline TGS & 6.0 & 0.03 & 200 & 0.20 & 0.5 & 0.80 & 1.5 & 2.0 & .0 \\
\hline OF & 5.0 & 2.00 & 400 & 0.05 & 0.3 & 0.996 & 2.0 & 2.0 & .0 \\
\hline OG & 5.0 & 0.80 & 400 & 0.05 & 0.3 & 0.996 & 2.0 & 2.0 & .0 \\
\hline \multirow[t]{2}{*}{ SA } & 5.0 & 2.00 & 100 & 0.001 & 0.5 & 0.80 & 10.0 & 2.0 & .0 \\
\hline & \multicolumn{9}{|c|}{ Model parameter ${ }^{1}$} \\
\hline $\begin{array}{l}\text { Land } \\
\text { segment }\end{array}$ & AGWETP & $\begin{array}{ll} & \text { CEPSC } \\
\mathrm{P} & \text { (in.) }\end{array}$ & $\begin{array}{l}\text { UZSN } \\
\text { (in.) }\end{array}$ & NSUR & INTFW & $\begin{array}{c}\text { IRC } \\
\text { (1/day) }\end{array}$ & LZETP & $\begin{array}{l}\text { RETSC } \\
\text { (in.) }\end{array}$ & DEEPFR \\
\hline EIA & $\mathrm{n} / \mathrm{a}$ & $\mathrm{n} / \mathrm{a}$ & $\mathrm{n} / \mathrm{a}$ & 0.10 & $\mathrm{n} / \mathrm{a}$ & $\mathrm{n} / \mathrm{a}$ & $\mathrm{n} / \mathrm{a}$ & 0 & $\mathrm{n} / \mathrm{a}$ \\
\hline TFF & 0.80 & 0.20 & 1.00 & 0.35 & 6.0 & 0.15 & 0.50 & $\mathrm{n} / \mathrm{a}$ & 0.25 \\
\hline TFM & 0.80 & 0.20 & .50 & 0.35 & 9.0 & 0.12 & 0.50 & $\mathrm{n} / \mathrm{a}$ & 0.25 \\
\hline TFS & 0.80 & 0.20 & .30 & 0.35 & 11.0 & 0.10 & 0.50 & $\mathrm{n} / \mathrm{a}$ & 0.25 \\
\hline TGF & 0.60 & 0.10 & .50 & 0.25 & 6.0 & 0.15 & 0.45 & $\mathrm{n} / \mathrm{a}$ & 0.25 \\
\hline TGM & 0.60 & 0.10 & .25 & 0.25 & 9.0 & 0.12 & 0.45 & $\mathrm{n} / \mathrm{a}$ & 0.25 \\
\hline TGS & 0.60 & 0.10 & .15 & 0.25 & 11.0 & 0.10 & 0.45 & $\mathrm{n} / \mathrm{a}$ & 0.25 \\
\hline $\mathrm{OF}$ & 0 & 0.20 & 0.60 & 0.35 & 0 & 0.70 & 0.70 & $\mathrm{n} / \mathrm{a}$ & 0 \\
\hline OG & 0 & 0.10 & 0.50 & 0.25 & 0 & 0.70 & 0.25 & $\mathrm{n} / \mathrm{a}$ & 0 \\
\hline SA & 0.70 & 0.10 & 3.00 & 0.50 & 1.0 & 0.50 & 0.40 & $\mathrm{n} / \mathrm{a}$ & 0.22 \\
\hline
\end{tabular}

${ }^{1}$ See table 1 for model parameter definitions. 


\section{Basin Calibration}

The final step in the calibration process, after values for the process-related parameters had been chosen for each land-segment type, was basin calibration. Basin models were constructed with calibrated parameters from the Cow Pasture and Rural Basin calibrations, Dinicola's (1990) parameter values, and basin characteristics determined from maps and field measurements as previously discussed. Simulated hydrographs were generated at all streamflow gaging sites for the first year of the data-collection period. At some sites little or no calibration was needed, and simulated hydrographs matched observed hydrographs closely. At many of the stream-gaging sites, especially sites near the mouths of basins, the match between simulated and observed hydrographs was poor. These basin models needed adjustments that were unique for each stream. Three types of adjustments made during basin calibrations all involved changes to volume and outflows of the FTABLE's in the numerical models:

(1) changes to outflows that simulated channel losses, (2) changes to outflows and volumes in the FTABLE's that represented the ground-water reservoir for each basin, and (3) changes to outflows and volumes to account for storage and release of storm runoff that was not accounted for in field surveys of characteristic channel cross sections. Basin calibration was subjective and relied heavily on comparisons of observed and simulated hydrographs and the hydrologic judgement of the modeler. Observations in the field during dry periods and especially during wet periods of the year and results from seepage runs were important sources of information that aided in the calibration.

Channel losses in most reaches were measured directly during seepage runs on the creek. The measurements, however, only provided the quantity of the losses at a particular stage of flow in the channel. The range of channel losses throughout the range of stages of flow within a channel was not known. This relationship was estimated by comparison of simulated and observed streamflows. If simulated streamflows agreed with observed streamflows upstream of a channel reach known to lose water and if the simulation downstream of the reach did not agree with the observed streamflow, outflow in the FTABLE representing channel losses was adjusted until a reasonable fit between simulated and observed hydrographs was obtained. This procedure assumed that the model was simulating all hillslope runoff to the reach correctly and that the error in the preliminary streamflow simulation was due to channel losses.
Ground-water reservoirs in the RCHRES block of the numerical model supply and regulate simulated base flow at the lower subbasins in the Clear and Clarks Creek Basins, at headwater basins and several points at gaining reaches on the main stem of Clover Creek, and in the Spanaway Creek Basin. Either continuous-recording stations or periodic discharge measurements at these locations provided data for making reasonably accurate estimates of base-flow contributions from a simulated ground-water reservoir. Observed seasonal and annual runoff totals were also used to calibrate outflows from the simulated ground-water reservoir. Outflows were balanced by inflows to the reservoir from recharge from the PERLND's and channel losses, and the outflows fluctuated during the water year according to the volumes in the reservoir. During the winter as inflows increased and volumes in the ground-water reservoir increased, outflows increased, and, likewise, during the summer inflows decreased, volumes decreased, and the outflows decreased.

The Clover Creek model, which included the recharge area for the ground-water reservoir by defining the southern and eastern subbasins according to ground-water flow boundaries, had a surplus of inflowing recharge to both simulated ground-water reservoirs. In both simulated reservoirs, an additional outlet gate was added to the ground-water reservoir FTABLE's that represented ground-water outflow out of the basin. The quantity of outflow from this gate was adjusted to maintain a slight gain (approximately 8 percent in the final calibration) in the final volume in the ground-water RCHRES at the end of the water year over the initial volume after all the other outflows were calibrated to measured streamflows. It was assumed that there was a little gain in the actual groundwater storage for the 1991 calibration year from the higher than normal quantity of precipitation, which was the source of recharge to the aquifers.

In preliminary runs of the Clear-Clarks Basin model, inflows to the simulated ground-water reservoir were not sufficient to maintain the outflows needed to match observed base flows at the mouths of the streams. The ground-water recharge area outside the surface drainage boundaries of the Clear-Clarks Basin was delineated from the ground-water flow boundaries drawn from the potentiometric map of the deep ground-water system produced from well-level data by Brown and Caldwell (1985, figs. 5-22). This recharge area outside the Clear-Clarks Basin boundaries (4,678.8 acres) extends south into the Clover Creek Basin and west beyond the Tacoma city limits and outside the study-area boundaries (fig. 3a). The acreage and type of land segments of this recharge area for 
the area common with the Clover Creek Basin were computed by methods discussed earlier in the text, but the land segments outside the study area had to be computed in a slightly different manner. The county soil survey maps do not extend into the Tacoma city limits, so a geologic map of central Pierce County (Walters and Kimmel, 1968, plate 1) was used to determine the land-segment type, which was mostly glacial till. Because the geologic map did not include slope classes, all the land segments were designated as flat, as indicated by the topographic maps. Land cover information was determined from aerial photos at a 1:24,000 scale (U.S. Department of Agriculture, 1979). The computed acreages of land segments for recharge areas outside the basin boundaries were added to the model, and only recharge from these segments was computed, which was subsequently routed into the simulated ground-water reservoir. One of the outlet gates on this reservoir was not routed into any simulated stream channel. It represented ground-water that discharges either out of the basin or into Canyon Creek, and it was simply accumulated by the model for summaries of the basin water balance. It should be noted that there was no routing of outflows from the ground-water reservoir into the simulated Canyon Creek channel because there were no observed data at the mouth of the creek from which to estimate the ground-water contributions that would have been simulated from the ground-water reservoir. Observed discharge data are needed before accurate simulation of low flows at the mouth of Canyon Creek can be obtained and validated.

In construction of the basin model, a field survey of representative channel cross sections was made for most subbasins. These surveys were made during summer when no water was flowing in the headwater basins, and it was difficult to define the extent of high water boundaries of the channel. Much of the headwater areas in the study area are flat, and during the wet season, many natural and man-made shallow ponds can be observed. The accumulated effect of the ponds is to provide a large reservoir of storage and slow release of outflows that reduce peak streamflows and attenuate the recession limb of the discharge hydrograph. Large ponds often form in the channel where outflow is controlled at a constriction in the channel such as a culvert. The field survey of representative cross sections did not account for these controlling constriction points, nor did it account for the ponding that occurred in swales or detention ponds not in the main channel. Some of the large seasonal ponds are shown on county drainage maps, whereas others can only be seen in the field during the wet season. The effects of the headwater seasonal ponds could be seen in preliminary runoff simulation by the numerical models. Preliminary simulated hydrographs would oversimulate peak flows, especially in the fall, and undersimulate flow between peaks. Volumes in the FTABLE's representing channel reaches for headwater channels were increased and outflows were decreased to account for the effects of seasonal ponding. Occasional stream discharge measurements were available in the headwater reaches to provide an instantaneous check for calibrating simulated outflows in these reaches. Attempts were made to quantify the volumetric changes in the FTABLE's by measuring the surface area of all the mapped ponds within the basin and estimating the added storm runoff volume these ponds would store. This provided an initial adjustment of the FTABLE's, but the final adjusted FTABLE's were a result of a trial-and-error calibration process of fitting the simulated hydrograph with the nearest observed hydrograph downstream of the headwater basin.

The progression of the basin calibration process is illustrated by several examples of hydrographs for the Clear Creek Basin (figs. 14-15). The preliminary run for Clear Creek at Pioneer Way, station number 12102140, (fig. 14) used the calibrated process-related parameters, but channel losses, ground-water discharge to the stream, and seasonal storage in ponds in the headwaters particular to this basin were not simulated in this version of the numerical model. The observed hydrograph (fig. 14) showed a constant base flow of approximately 8 cubic feet per second throughout the year. The simulated hydrograph showed the creek to be dry for about half of the year because no ground-water discharge into the channel was being simulated. In addition, the simulated hydrograph greatly oversimulated the peak flows: The January 9 peak was simulated at 264 cubic feet per second, and the observed peak (estimated from reconstruction of the observed hydrograph unaffected by backwater and from comparison with the observed record at nearby Swan Creek) was only 180 cubic feet per second. The observed annual runoff for the 1990 water year was 44.01 inches, or 22.91 inches more than the simulated runoff for the preliminary calibration run. 

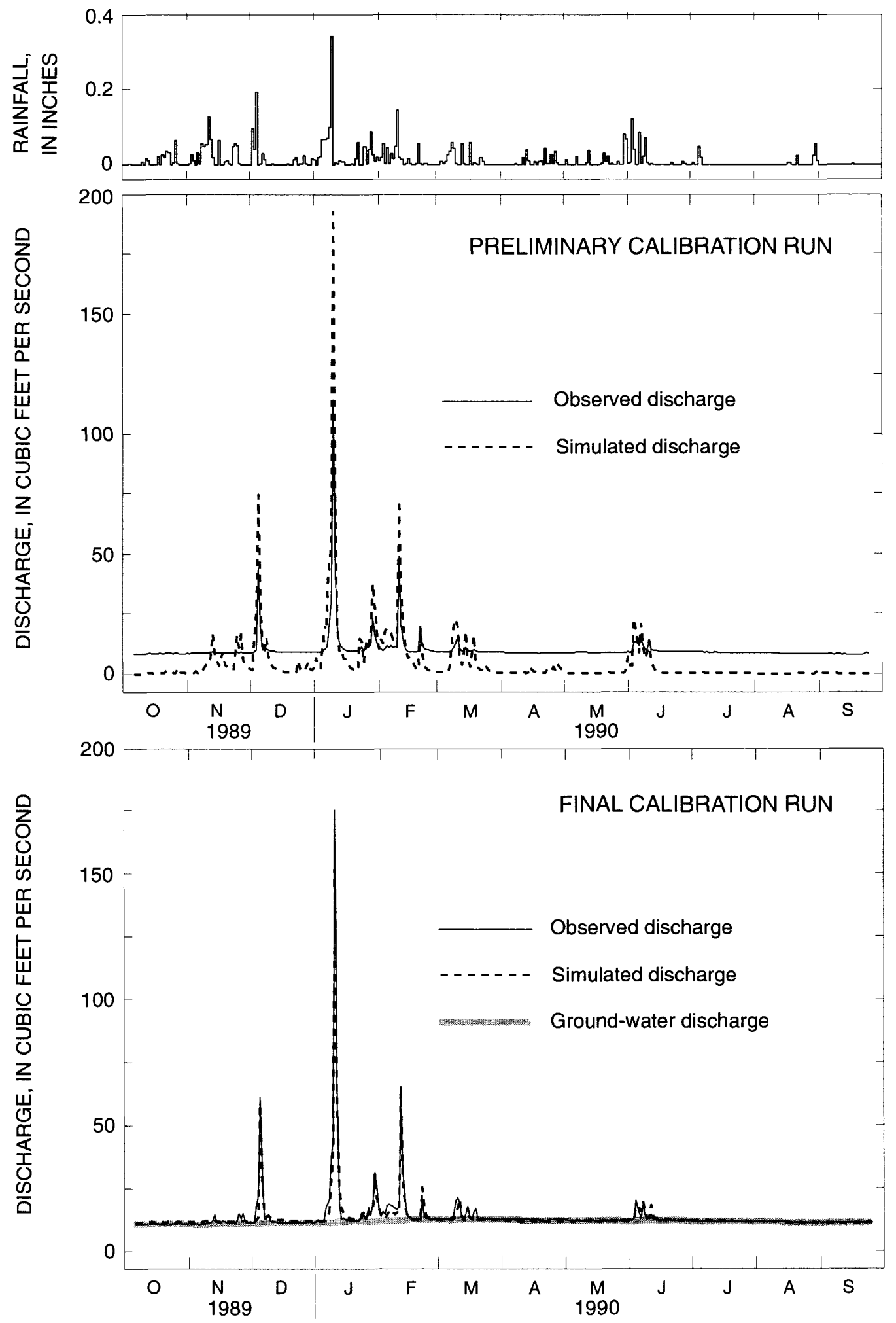

Figure 14.--Simulated and observed discharge at Clear Creek at Pioneer Way for the preliminary and final calibration model runs and rainfall at the Canyon Road gage, Pierce County, Washington. 

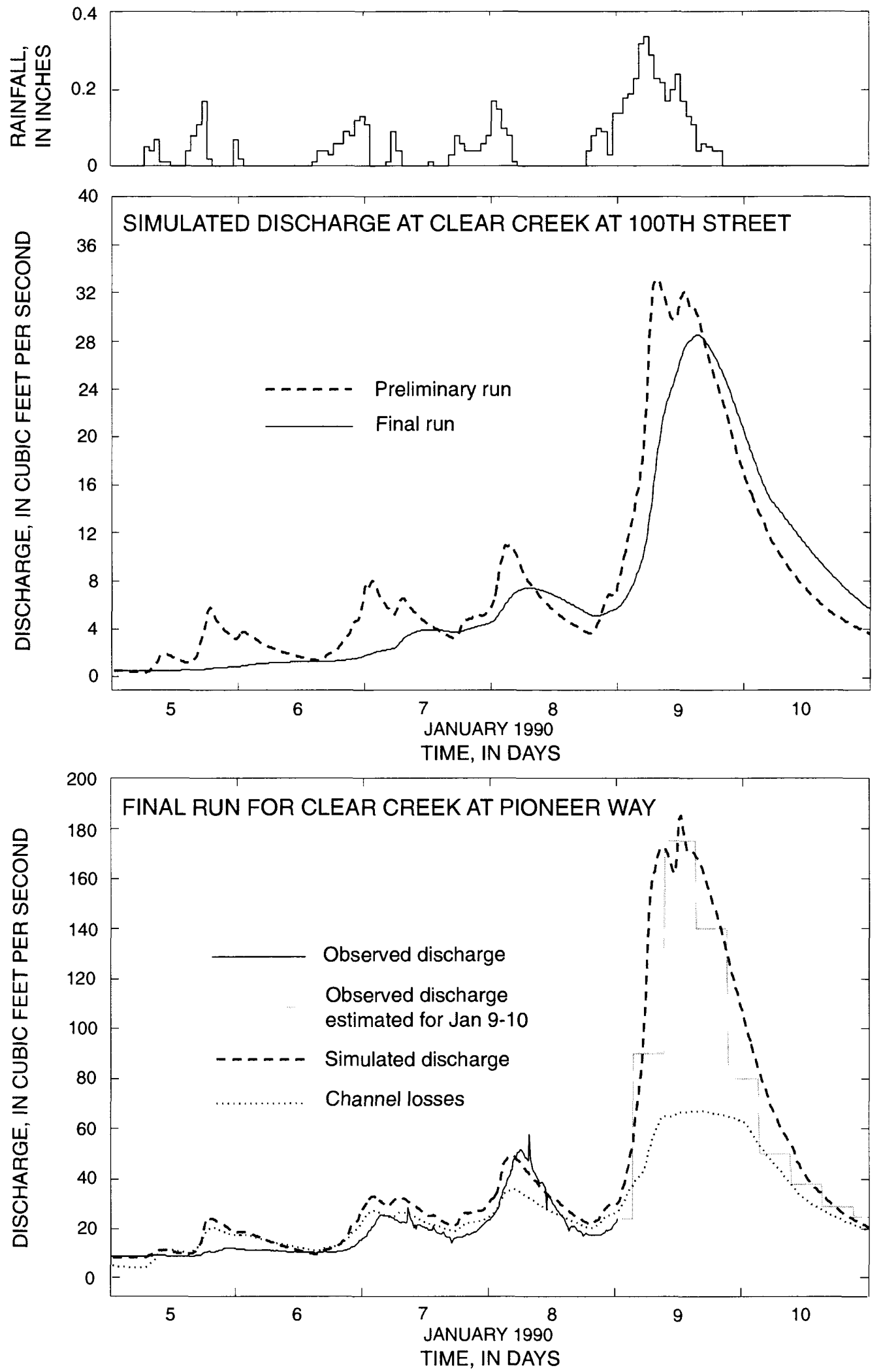

Figure 15.--Preliminary and final calibration model runs at Clear Creek at 100th Street East, observed and simulated discharge and simulated channel losses for Clear Creek at Pioneer Way, and rainfall at the Canyon Road gage, Pierce County, Washington. 
The accounting of simulated runoff for Clear Creek shows how this creek in particular is influenced by regional ground-water discharge. In the final calibration model run for Clear Creek at Pioneer Way, ground-water discharge (shown as a dotted line on fig. 14) was simulated by outflows from the ground-water reservoir that produces a nearly constant outflow of about 8 cubic feet per second throughout the year. An equivalent of 16.75 inches of recharge from the surface-water drainage boundaries of Clear Creek was inflow to the ground-water reservoir, but 38.02 inches of runoff from the simulated ground-water reservoir was required to balance the annual simulated and observed runoff-a difference of 21.27 inches representing ground-water discharge derived from recharge outside of the surface-water boundaries of Clear Creek.

The oversimulated peak flows for East Fork Clear Creek at 100th Street East and Clear Creek at Pioneer Way were reduced by increasing the volume in the FTABLE's representing the headwater reaches in the east fork of Clear Creek and adding a second outflow to the FTABLE's of several reaches to represent channel losses. Three crest-stage gages were located in the upper portions of the drainage basin to aid in calibration of the Clear Creek part of the Clear-Clarks model. The preliminary calibration run showed that peak flows on the east fork Clear Creek were oversimulated. A review of drainage maps for the headwater region showed several large ponds; one of the ponds above the crest-stage gage at 100 Street East was mapped with a seasonal boundary enclosing 5.9 acres. Many trial model runs were made with changes to the volumes and outflows in the FTABLE's that represented these headwater reaches to account for this storage and reduce simulated peak flows until they more closely matched observed flows. The effects of changes between the preliminary and final calibration runs can be seen in the storm hydrograph of peak flow of the water year on January 9 at a point representing flow at the crest-stage gage at East Fork Clear Creek at 100th Street East (fig. 15). The final simulated discharge closely matches a discharge measurement for the peak of 25.1 cubic feet per second made at this site on January 9. The FTABLE representing the reach above this gaging station was given additional volumes-from 0.6 acre-foot at the lowest stage where the channel surface area, volume, and outflow are specified to 10.2 acre-feet at the highest specified stage - and the outflows were reduced to about 20 percent of the original values calculated from field surveys of the channel cross section. The effect of these changes was to reduce the peak flow and increase the lag time between peak rainfall intensity and peak discharge. Although the simulated January 9 peak discharge in the final calibration run was still 3.5 cubic feet per second higher than the observed dis- charge, it represented a balance of other errors between observed and simulated discharges in the basin model. Reducing the peak further would increase errors downstream. Seepage runs at the gaging stations showed that channel losses occur in several of the simulated reaches. These losses were simulated by adding a second outflow gate in the FTABLE's representing reaches where these losses occurred. The simulated channel losses were directed to the ground-water reservoir and later returned to the channel ground-water discharge at a downstream location where springs are reported (Ed McLeary, operator of the hatchery on Clear Creek, Troutlodge, Inc., oral commun., December 1989). Channel losses were important in decreasing oversimulated peak flows at Clear Creek at Pioneer Way. Figure 14 shows the January 9th observed and simulated storm hydrograph at Clear Creek at Pioneer Way and the total quantity of channel loss in all of the Clear Creek stream channels. The hydrograph shows that the quantity of simulated channel losses can be a large proportion of the total simulated runoff at this site, especially at medium peak flows.

For the most part, the basin calibration procedure described for the Clear Creek example was followed for each of the separate creek systems in the two basin models, but several additional strategies were needed for Diru Creek and Clover Creek. Simulation of Diru Creek required the addition of 0.47 cubic foot per second of water (except for a period when the well was shut down in September 1991) to the lower reach to simulate the constant addition of water from a deep well by the hatchery located just above Pioneer Way. The Clover Creek simulations required several additional strategies to improve the calibrations.

In the Clover Creek model, comparisons of simulated and observed hydrographs at the mouths of two reaches in the outwash plain, reaches 5 and 13 where channel losses were observed, indicated variable rates of loss. During fall when the level of the water table was low, the simulated hydrograph consistently oversimulated flows, and during the winter when the water table rose, low-flow period streamflows were generally undersimulated. It is believed that the rise and fall of the water table changes the reach seasonally from a ground-water discharge area to a ground-water recharge area. To simulate these variable channel losses and gains, variable outflows from the upper ground-water reservoir were routed into the reaches, and simulation of stream flows improved. The outflows are zero until the simulated ground-water reservoir has reached a mid-level stage in the reservoir, and they increase as the stage increases. 
On the main stem of Clover Creek, preliminary simulations of runoff tended to oversimulate peak flows. The volumes in the FTABLE's for the highest stages of flow in the channel for these reaches (reaches 1, 5, 15, and 23) were increased to reduce peak flows and attenuate the recession limb of the simulated storm hydrograph. The increases were made because at various low spots in the channel, high flows can overflow the banks into the floodplain, become temporary storage that reduces peak flows, and return to the channel slowly as storm waters recede. Overbank flow was observed at stages lower than predicted by the original compilation of the FTABLE's, and therefore, increases in the channel volumes at high stages seemed reasonable.

In the southeastern portion of Clover Creek, three large subbasins-SP1, CL1, and CL2--defined by ground-water flow paths were further subdivided into small subbasins immediately surrounding the channel reach and larger subbasins remote from the reach. Runoff from the smaller subbasin was directed into the channel reach because it is believed that the smaller subbasin is more directly connected to the reach than the distant parts of the subbasin that must follow a long ground-water pathway before entering a surface-water channel. An exception was made for the smaller basin in CL1 (CL1A) where the till land segments are separated from the stream channel by outwash land segments. The runoff from these segments was directed directly into the ground-water reservoir. All runoff from the remaining larger subbasins was directed to a simulated ground-water reservoir. Subbasins CL1 and CL2 were subdivided into smaller, directly connected subbasins (CL1A, and CL2A) along the ridge line defining the southern boundary of the surface-water drainage basin for reaches 1 and 2 where direct connection to the reach was apparent. Highways 7 and 507 were used to subdivide SP1A because the highways provide a definite boundary for the large wetland area and surrounding land that would drain immediately into reach 17 , the surface-water drainage channel for subbasin SP1.

During the data collection period for stream discharge on Clover Creek, a local conservation group, Clover Creek Council, sponsored several stream restoration projects on 6 days during February and March 1992 with the goal of reducing the channel losses on the main stem of Clover Creek in order to maintain sufficient streamflows throughout the year and increase the fish rearing potential of anadromous fish (primarily salmon). The projects consisted mainly of restoring the stream banks with sand bags and clay along the stretch of the Creek just upstream of 138th Street South where channel losses were large as water diverged into two channels, overflowed the low banks during low- and high-flow periods, and maintained a large swampy area. The area of the projects is within RCHRES 5 of the Clover Creek Basin model. Seepage runs were performed before and after the work was completed and showed that the projects were effective in reducing channel losses during the low-flow periods (table 5). Channel losses for RCHRES 5 were recalibrated for the period after the projects were completed. Streamflows were simulated for the period October 1 , 1990, through February 29, 1992, using the original calibrated channel losses for RCHRES 5, and all the final volumes of water stored in all the RCHRES's and land segments were computed. The stored volumes were added to a new model run as the initial volumes to all the RCHRES's and land segments, and the new model run containing the recalibrated channel losses for RCHRES 5 simulated flows for the period March 1, 1992, through September 30, 1992. Output from these two model runs was used for comparison of observed and simulated discharges in Clover Creek.

Routing streamflows to the ground-water reservoir to represent channel losses and increases in channel volumes was an important tool to reduce peak flows that were generally oversimulated in the preliminary calibration runs. Results from the catchment studies support the selected process-related parameters for the till-covered basins, and therefore, the peak runoffs from hillslopes to the channels are believed to be accurate. Field surveys of one representative cross section per reach failed to characterize the hydraulic parameters accurately for routing streamflows in the flat headwater reaches and broad floodplain reaches of the main stem of Clover Creek, nor did they identify areas of channel losses. However, observations of seasonal ponds in the headwater areas, overbank flow on the main stem of Clover Creek, and channel losses during seepage runs support changes made to the models during the calibration process. The calibration of the regional groundwater components of the model proceeded despite the fact that the dynamic nature of the ground-water flow processes and the identification of source areas of ground water were not well understood. The simulation of the aquifers in the study area by equations for surface-water reservoirs seemed to work well to distribute the ground water properly, although it required many computer runs to obtain the proper balance of inflows and outflows at various stages of volume in the ground-water reservoir and the proper dimensions of the reservoir. 


\section{RESULTS FROM RUNOFF SIMULATIONS}

Does the numerical model represent the surface-water hydrology of the study area? To answer this question the major spatial and temporal characteristics of the hydrologic system are presented as represented by the numerical model and observed data. Four topics are discussed in this section. They include (1) a description of the precipitation patterns in the study area represented by the precipitation data, (2) a comparison of simulated runoff with observed runoff, (3) an accounting of how the numerical model distributes water through the hydrologic system, and (4) a presentation of the results of long-term model runs.

The first topic of the hydrologic system discussed is precipitation because it is the primary input for generating runoff. Comparison of observed precipitation data with averages of a long-term weather station shows how well the period of data collection represents the normal and extreme conditions that may be encountered in the study area. The second topic discussed is that the ability of the models to generate runoff that matches observed runoff indicates the success of the numerical model. It is also a measure of the success of the conceptual model to identify the important runoff processes in the study area. Many representative hydrographs and a variety of error analyses are provided to the reader. Next, water budgets generated by the numerical model for all the land segments and most of the basins are provided to illustrate how the general physical properties of the watersheds in the study area affect runoff processes and whether the simulation model is generating runoff according to the guidelines of the conceptual model. The final topic shows how simulated runoff during the period of data collection compares with simulated runoff for 31- and 32-year periods of simulation and how stable the range of volumes in the simulated ground-water reservoirs is during the long-term simulation.

\section{Precipitation Patterns}

Analysis of precipitation totals recorded at the precipitation gage sites shows variation in the quantities recorded, but no distinct rainfall pattern was evident. Monthly and annual precipitation totals at all sites were compared with the totals at the Canyon Road site, the only site that operated throughout the data-collection period, water years 1990-92 (table 7). The maximum difference in the monthly totals from the Canyon Road site was 1.58 inches more rain recorded at the Waller Road gage for October 1990. The pattern is highly variable between months, however. For example, Elk Plain gage recorded 5.53 inches less than Brown's gage for the 1992 water year, the largest annual difference between two gages, but it recorded 0.51 inch or 26 percent more rain than the Brown's gage for the month of October during the same water year. No orographic effects influencing precipitation were evident. The gage at the highest elevation - the Canyon Road gage (470 feet) - had a similar but slightly smaller rainfall total than the Spanaway Park gage, the lowest elevation gage ( 345 feet). No regional rainfall pattern could be found within the study area either. For example, Brown's and Elk Plain precipitation gages are located within 3 miles of one another in the southern region of the study area, but they represent the extremes in recorded annual precipitation totals. A general pattern of evenly distributed precipitation is somewhat apparent in the rainfall totals for the winter months when rain commonly falls from large frontal storms of low intensity and long duration. The pattern is less apparent during the spring through fall seasons when localized storm systems are more common and rain falls in more variable quantities within the study area. Increasing the number of rain gages in the study area would improve the accuracy of the areal distribution of rainfall, but the percent errors of the annual totals-all within 9.1 percent of the Canyon Road precipitation totals-suggest that the rain gage distribution of approximately one gage per 14.5 square miles provided reasonable definition of the distribution of rainfall in the study area. 


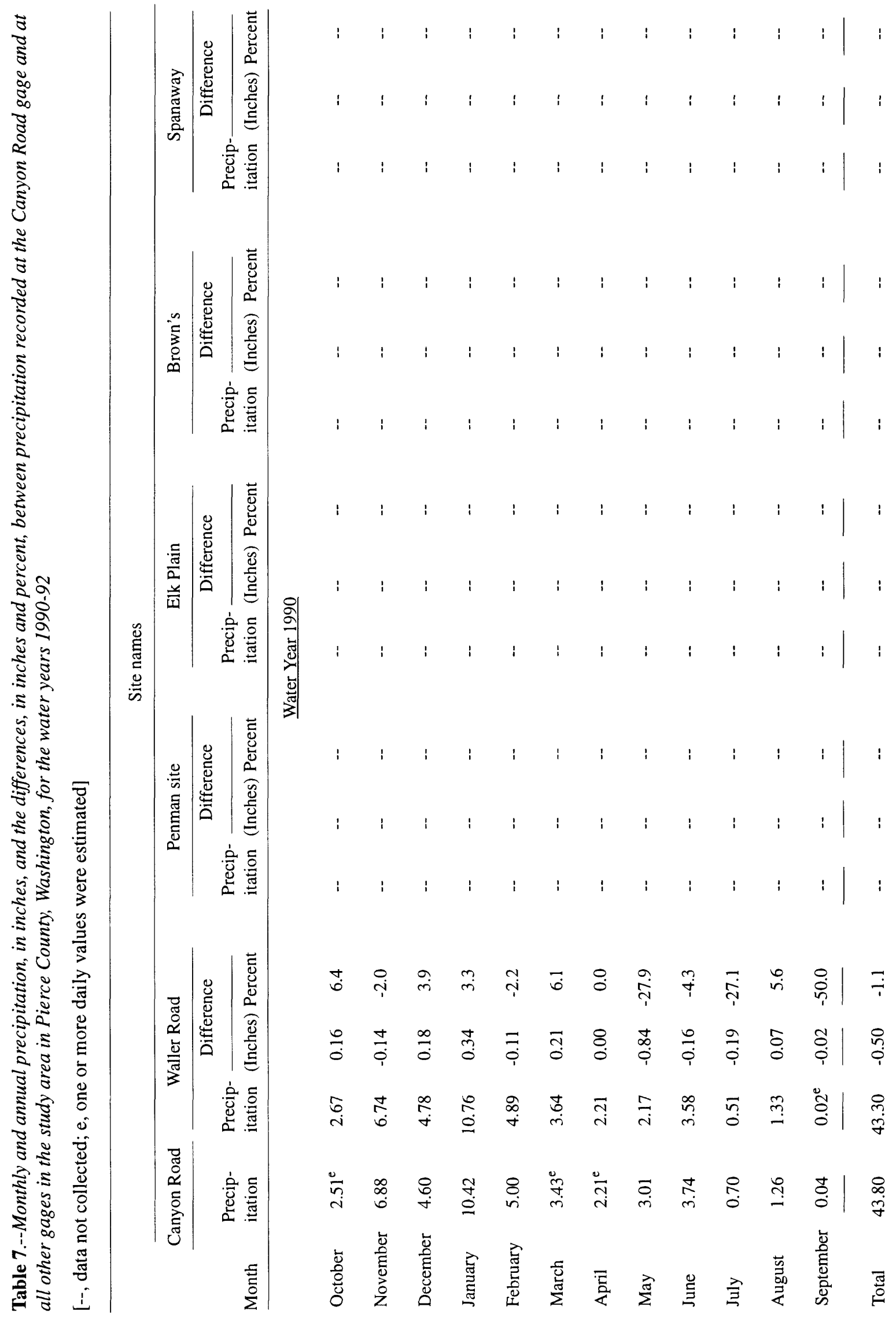




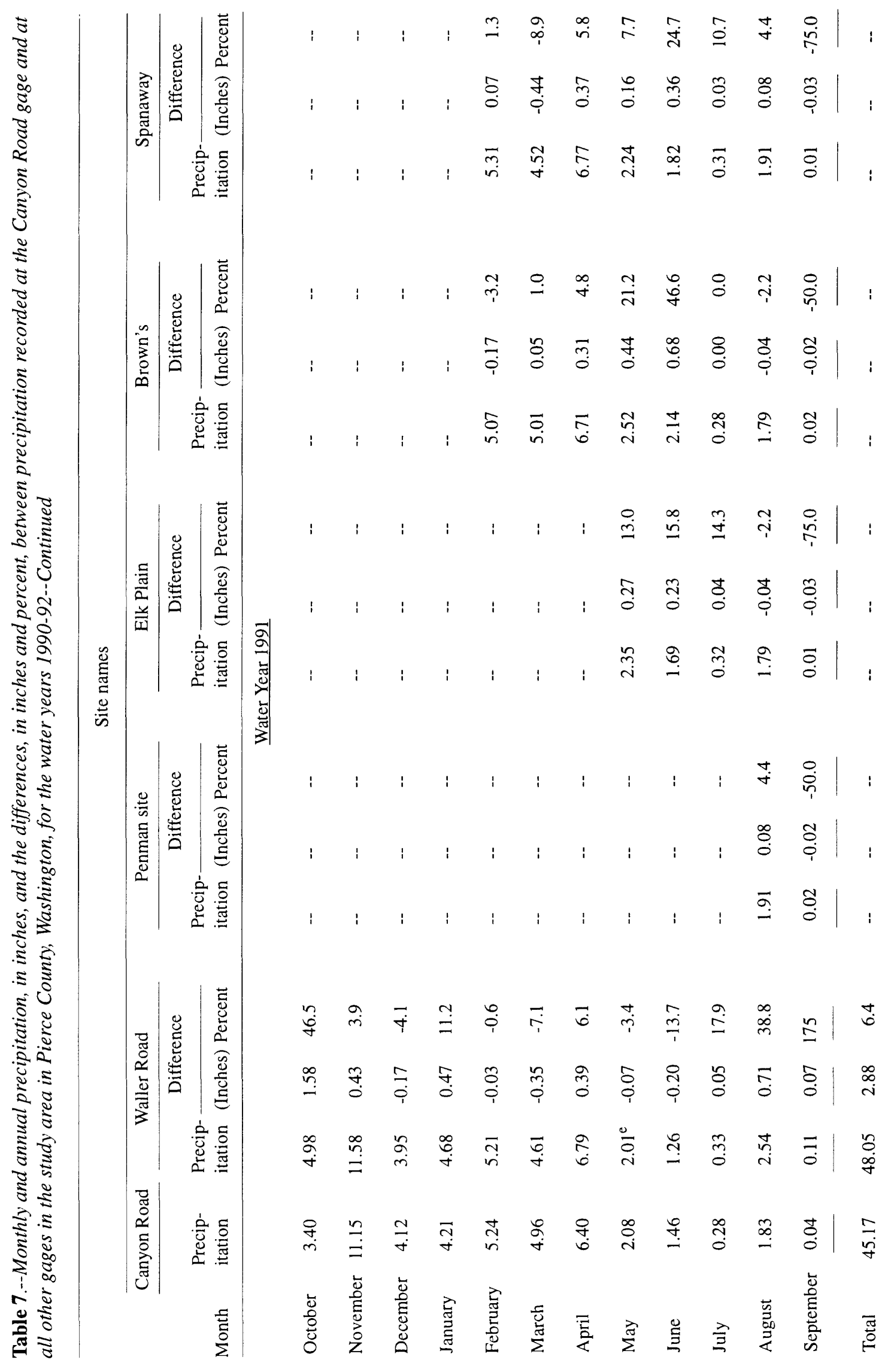




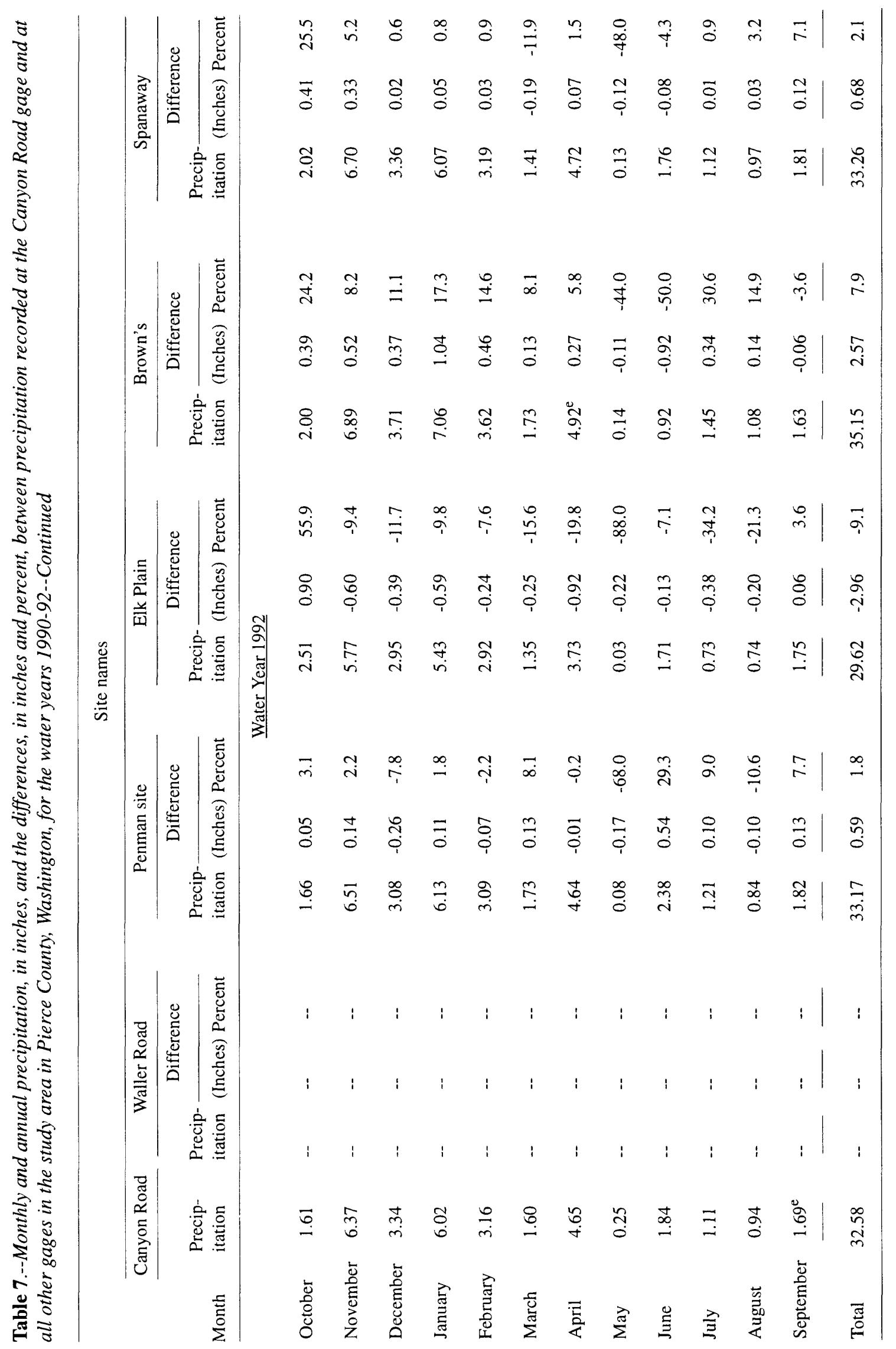


The precipitation record for the period of data collection shows that the two hydrologic extremes, flooding and drought, were represented for calibration and validation of the numerical model. The heavy precipitation in the early part of January 1990 resulted in extreme flooding in most of the streams and rivers in Pierce County, and the low annual precipitation for the 1992 water year resulted in well-below-average runoff for many of the same streams and rivers. The January 9, 1990, flood was a result of several back-to-back storms, with the maximum daily precipitation occurring on January 9. The Canyon Road precipitation gage recorded a maximum 24-hour total of 3.79 inches, and the Waller Road gage recorded a maximum of 3.73 inches. The estimated 50-year, 24-hour precipitation is 3.50 inches (U.S. Department of Commerce, 1973). (The 50-year, 24-hour precipitation is the total rainfall over a 24 -hour period that is exceeded on average only once every 50 years). No record exists of streamflows on Clover Creek for this storm, but all of the Clear-Clarks Basin stream gages were in operation, although several lost usable streamflow record during the flood and peak flows had to be estimated.

With the McMillin Reservoir precipitation records for comparison, the data-collection period can be characterized as 2 wet years followed by a relatively dry year. Figure 16 shows the monthly and annual total of precipitation for the data-collection period for the Canyon Road and McMillin Reservoir rain gages compared with the long-term averages for McMillin Reservoir. It shows that the McMillin Reservoir rain gage compares well with the Canyon Road gage and the study area in general. The first 2 years were wetter-than-average years, with the 3 highest above-average monthly precipitation months corresponding with the three largest storms: January 5-10, 1990, November 21-26, 1990, and April 2-6, 1991. Water year 1992 represents a year of below-average precipitation. Eight of the 12 monthly totals of precipitation at the nearby long-term station, McMillin Reservoir, were below the 1951-80 normal (fig. 16). This was not an extreme drought year -7 water years during 1951-80 had lower annual precipitation totals (U.S. Department of Commerce, 1990)--but the year had 6.3 inches less than average and 13.2 inches less than the calibration year for the Clover Creek model, and it provided a good validation test of the ability of the Clover Creek model to simulate low flows. The low precipitation totals for water year 1992 resulted in low runoff totals and no stormflows that approach the magnitude of flooding in the previous 2 water years. Almost all of the precipitation fell as rain. Only 6 days of measurable snowfall were recorded at McMillin Reservoir during the data-collection period; the maximum daily total snowfall was 3.0 inches, and the maximum depth on the ground was 4.2 inches for the same period (U.S. Department of Commerce, 1989-92). 

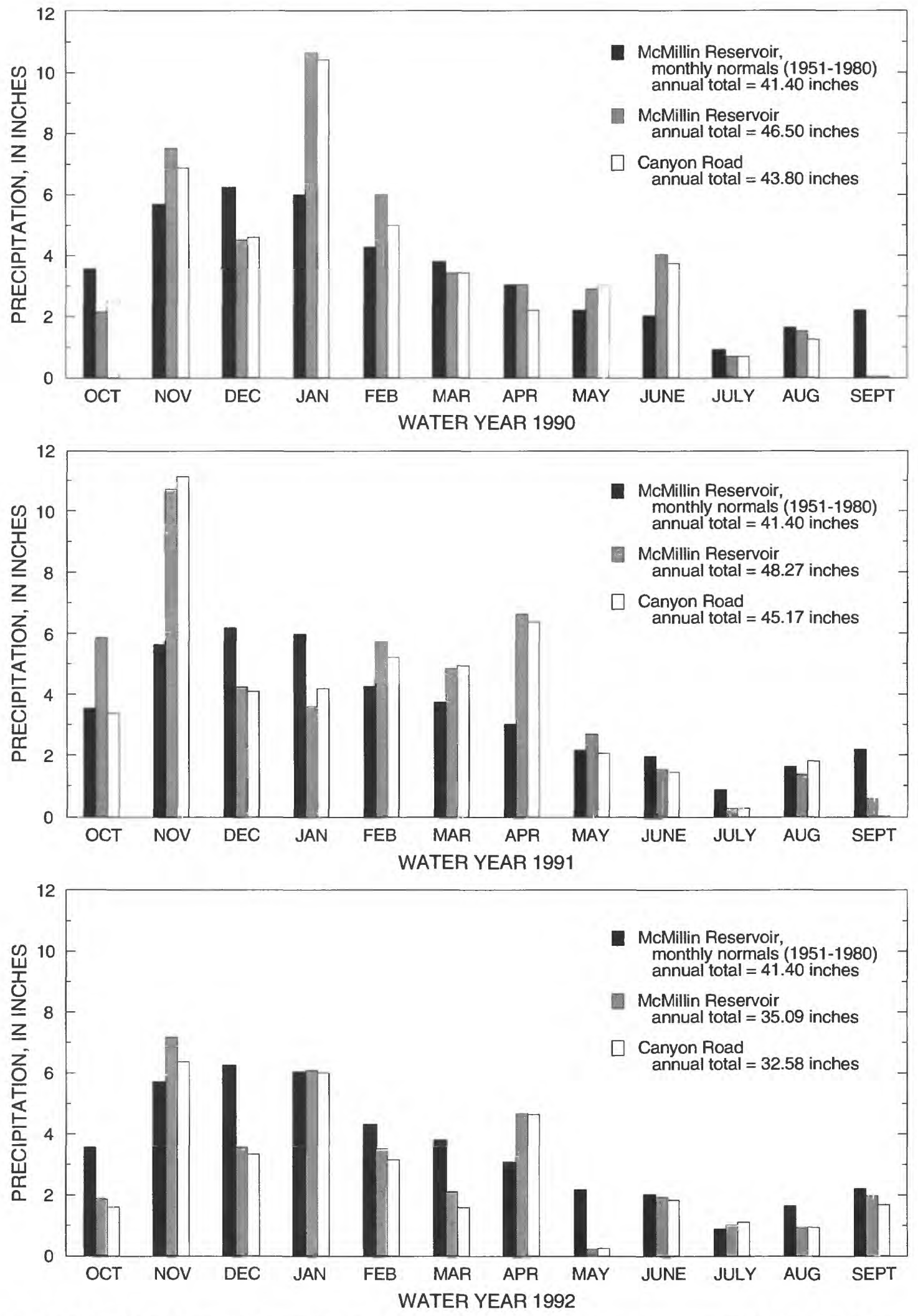

Figure 16.--Monthly normal precipitation and monthly precipitation for water years 1990-92 at McMillin Reservoir (U.S. Department of Commerce, 1989-92) and observed monthly precipitation at the Canyon Road gage, Pierce County, Washington. 


\section{Comparison of Simulated and Observed Runoff}

Several methods of comparing simulated and observed runoff are used in this section. Examples of hydrographs are shown at different time scales to illustrate how errors were evaluated in the simulation model and how the model was validated. This graphic comparison method was used extensively during calibration of the models, but it does not always convey the magnitude of some of the errors or allow easy comparisons with the errors from other sites. These quantitative error estimates are, however, provided by actual and simulated runoff measured as the total runoff in inches (the quantity of water required to cover the drainage area to a depth of $1 \mathrm{inch}$ ) or as the rate of flow in cubic feet per second. These quantities are provided in tables 8-11 for all the continuous-recording streamflow stations for annual and seasonal runoff, peak discharges, storm runoff volumes, and daily mean discharges. Crest-stage gages only provide peak discharges; therefore, only peak discharges can be compared at these sites. A general discussion of errors shown in the tables and the hydrographs is provided at the end of this section.

\section{Annual and Seasonal Runoff}

Three runoff patterns typify the hydrologic response of the study area to rainfall, and the patterns were successfully simulated by the numerical models. The three patterns of the rainfall-runoff relationship at the 10 continuous-recording streamflow sites can be seen in the 2-year hydrographs of observed and simulated daily discharge and daily precipitation (figs. 17 to 26 ).

The first pattern is found at the headwater stations in the glacial till watersheds- the three catchments sites, the North Fork of Clover Creek (station 12090400, fig. 21), and Swan Creek at 80th Street East (station 12102190, fig. 25). At these sites there was a quick response to rainfall that resulted in sharp spiked peaks in the hydrographs immediately following the rainfall peaks. All the streams went dry in the summer months and showed little or no response to summer or early fall rainstorms.
The second pattern of rainfall-runoff is similar to the first, but ground-water discharge into the streams maintained base flow throughout the year, and the streams never went dry. This pattern is seen in the hydrographs for the three stations along Pioneer Way near the mouth of the predominately glacial till basins, Diru Creek (station 12102025, fig. 23), Clear Creek (station 12102140, fig. 24), and Swan Creek at Pioneer Way (station 12102212, fig. 26). The hydrographs show that the response to rainfall was similar to that at the headwater stations, showing peaks that respond quickly to the rainfall peaks and steep recessional limbs of the hydrograph that returned to relatively constant base-flow discharge.

The third rainfall-runoff pattern can be seen in the two hydrographs representing basins dominated by glacial outwash soils, Clover Creek at 25th Avenue East (station 12090355, fig. 18) and Clover Creek near Tillicum (station 12090500, fig. 22). Little change in runoff occurred following rainstorms, and the recession limb of the hydrographs extended for several weeks after the peak discharge. Ground-water discharge tended to increase through the fall and winter months and was important in determining the quantity and timing of the maximum annual peak flows. For example, during the 1991 water year, the peak daily discharge occurred on November 24 at the North Fork of Clover Creek (station 12090400, fig. 21), a station representing a basin with minimal ground-water contribution to storm runoff. During the storm, discharge increased from a low of approximately 5 cubic feet per second, 4 days prior to a peak of 423 cubic feet per second and a peak mean daily flow of 272 cubic feet per second. On the same day at Clover Creek at 25 th Avenue East (fig. 18), the base flow before the storm was approximately 7 cubic feet per second, and the peak discharge was only 53 cubic feet per second. By April of the same year, the base flow at Clover Creek at 25th Avenue East had increased to approximately 24 cubic feet per second, and a rainstorm on April 4 caused the peak of the water year (74 cubic feet per second) which was significantly higher than the November peak primarily because pre-storm base-flow discharge was higher. At the North Fork of Clover Creek station, the April storm resulted in similar runoff as the November storm at the same station. Again the discharge 4 days prior to the peak was approximately 5 cubic feet per second, and it increased to an instantaneous peak of 474 cubic feet per second and a peak mean daily flow of 253 cubic feet per second. 
The three runoff patterns were successfully simulated by the models, as was demonstrated by the fact that differences between observed and simulated runoff during the validation period were not much greater than the differences experienced during the calibration period. The difference between the observed discharge (solid lines, figs. 17-26) and the simulated discharge (dashed lines, figs. 17-26) in the comparison hydrographs are indicative of the model error during the period of calibration and validation. The difference is not the true model error, however, because the error of the observed discharge (unknown) has not been added to the difference. The first water year shown in the hydrographs (figs. 16-25) is the period of calibration when efforts were made to minimize the difference between the two hydrographs. The second water year is the period of validation when the final calibrated model was left unchanged and simulations were allowed to run through the second water year. In most cases, the simulation discharge record did match the observed record well, and the same degree of errors seen in the calibration period was found in the validation period.

Two general errors in the annual hydrographs of observed and simulated discharge (figs. 17-26) were not random and indicate some deficiencies in the ability of the model to accurately simulate the actual hydrologic processes. The simulated runoff tended to be more responsive to summer and fall rainstorms than the observed runoff. This responsiveness sometimes caused the model to simulate small discharge peaks when no peaks were observed. This situation is especially apparent in the suburban catchment hydrograph (station 12090340, fig. 17). Efforts were made to correct this error during the calibration process, but changes to one aspect of the model to correct a specific error often resulted in new errors. A second general error in the simulation model can be seen on the two hydrographs for the Clover Creek stations (stations 12090355, fig. 18, and 12090500, fig. 22). The simulated peak discharge tended to occur slightly before the observed peak. Calibration efforts to delay the simulated peaks generally resulted in less accurate simulation of the magnitudes of the peaks; therefore, some error in the timing of the peaks was accepted in order to avoid other errors. The final calibrated model represents a balance of errors distributed throughout the hydrograph.

Observed annual and seasonal runoff, measured in inches of runoff, for the basin for each of the continuousrecording streamflow sites was compared with simulated values (fig. 27; table 8). Figure 27 shows fairly equal distribution of annual, winter, and spring runoff on either side of the 45 degree line that represents exact simulation of the observed runoff. For the lowest flows of the summer season, however, the runoff points plot above the 45 degree line, indicating a positive bias of the model to oversimulate the lowest summer streamflows. Table 8 shows the actual difference in inches and percent difference. The three catchment sites show some of the largest differences; however, these were the sites where the error of the observed discharge is believed to be the highest. Differences between the simulated and observed annual discharge for the calibration period were as large as -4.65 inches or -14.7 percent (station 12090340) for the catchment sites, and -0.78 inch or -9.3 percent (station 12090355) for the basin model sites. Apart from these two sites, percent differences during the calibration period ranged from -5.1 percent to 1.4 percent.

For the validation period, the largest difference was -4.10 inches ( 14.8 percent), and the largest percent difference was 25.7 percent ( 2.72 inches) at the Mixed-Use Catchment. The percent differences ranged from -12.0 to 15.8 percent for the other sites. Winter and spring runoff periods show similar results. The Suburban Catchment shows the largest difference for these seasons, - 7.27 inches ( -29.5 percent). At other sites, the largest difference in inches was -1.91 inches (10.5 percent) for the calibration period and -3.39 inches (18.2 percent) for the validation period. Percent differences at these other sites ranged from -20.6 to 8.7 percent for the calibration period and -28.9 to 42.2 percent for the validation period. For the summer season, the Suburban Catchment had the biggest difference, 0.75 inch; at other sites the largest difference for the summer season was -0.40 inch ( 11.8 percent) during the calibration period and 0.23 inch $(2.4$ percent $)$ during the validation period. Large percent differences resulted despite the small differences in inches. The largest percent difference for the calibration period was 83.3 percent, although the difference in inches was only $0.05 \mathrm{inch}$, and for the validation period, the largest percent difference was 700 percent, or only 0.07 inches. At sites (stations 12090340, 12090365, 12090380, 12090400, and 12102190) where streams become dry in the summer, the models showed a bias of oversimulating streamflows during the validation period. Percent differences were high, ranging from 48.5 to 700 percent. At the other sites where streams flowed all year, percent differences ranged from -1.6 to 41.2 percent. 


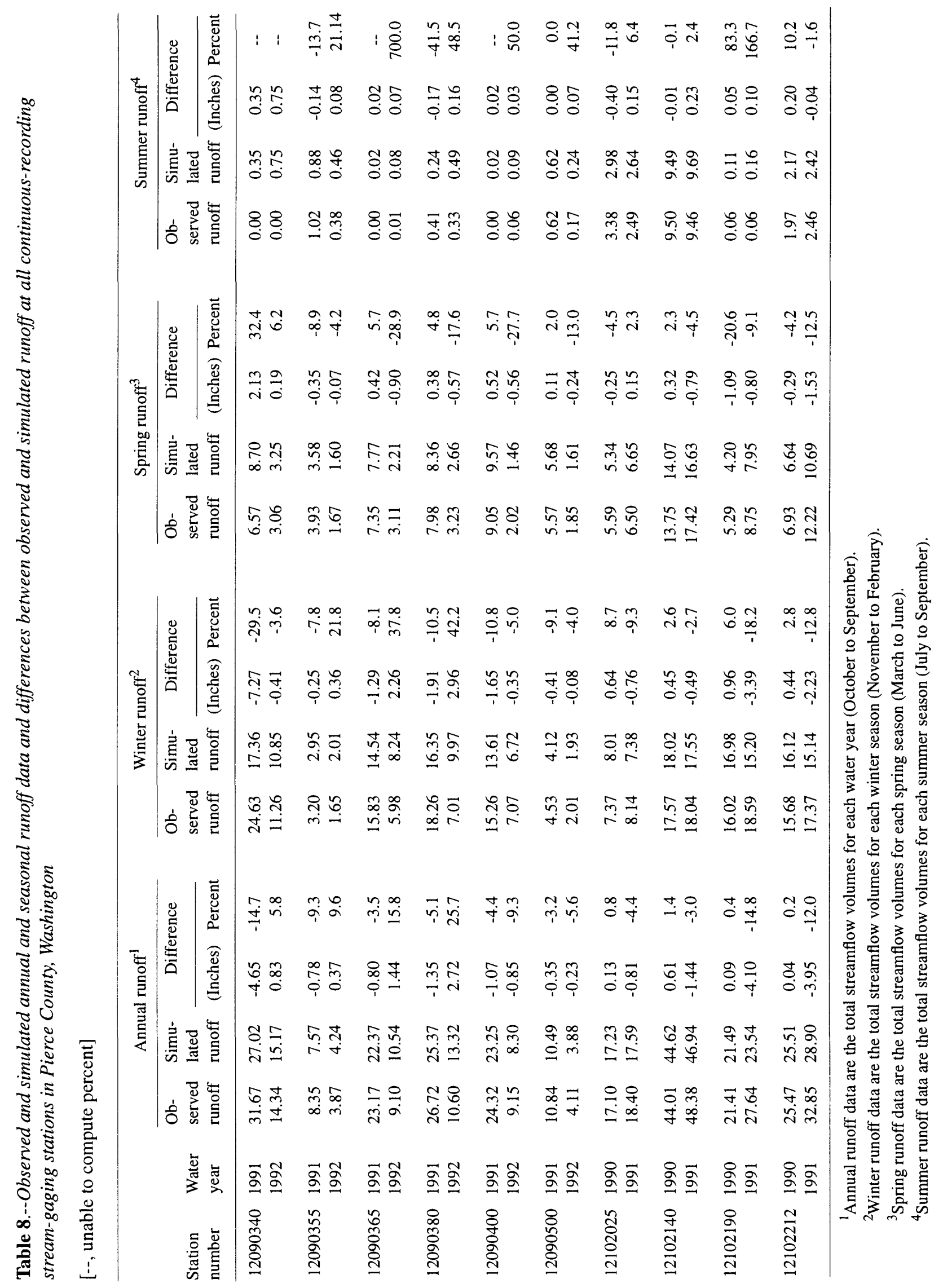




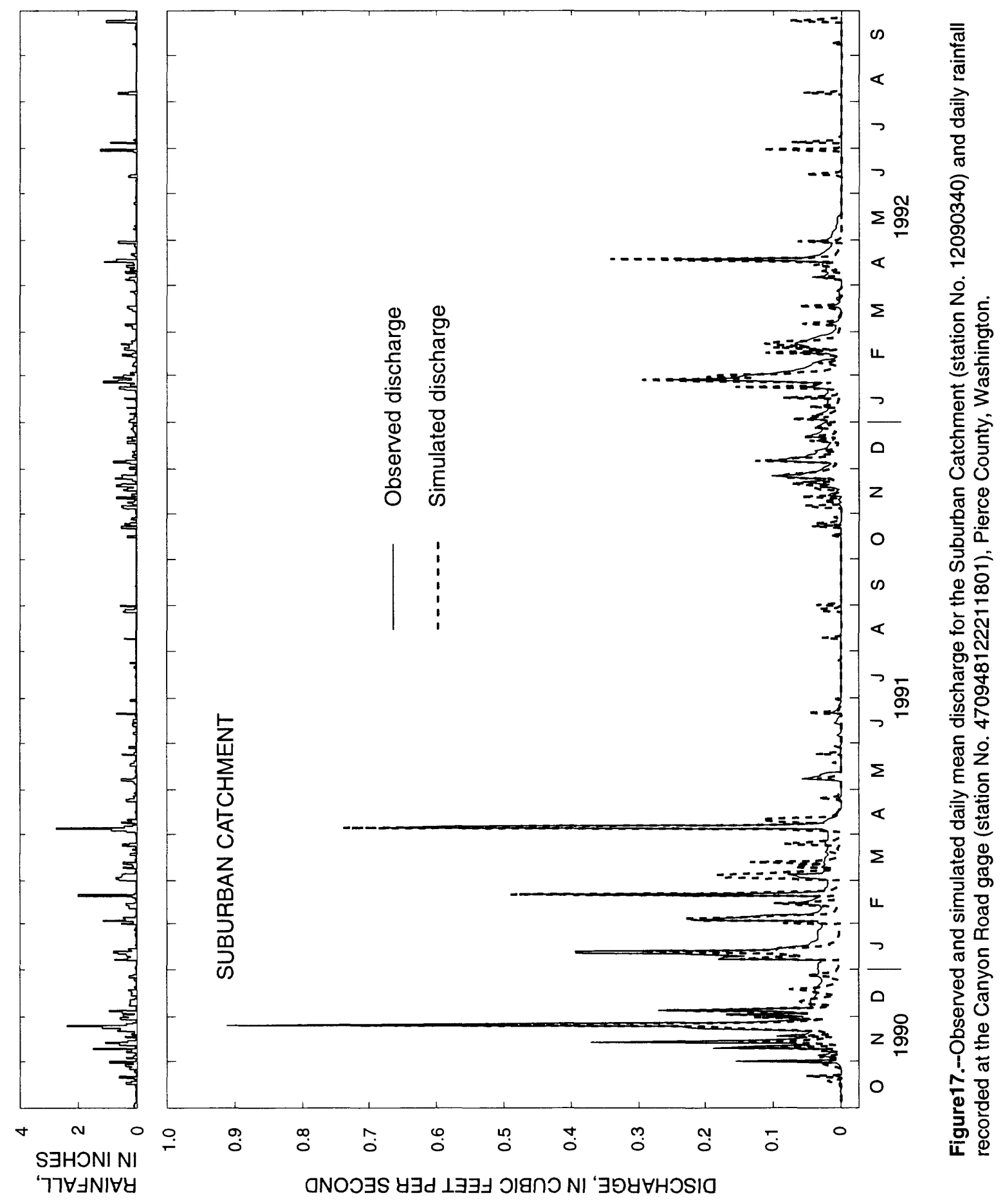




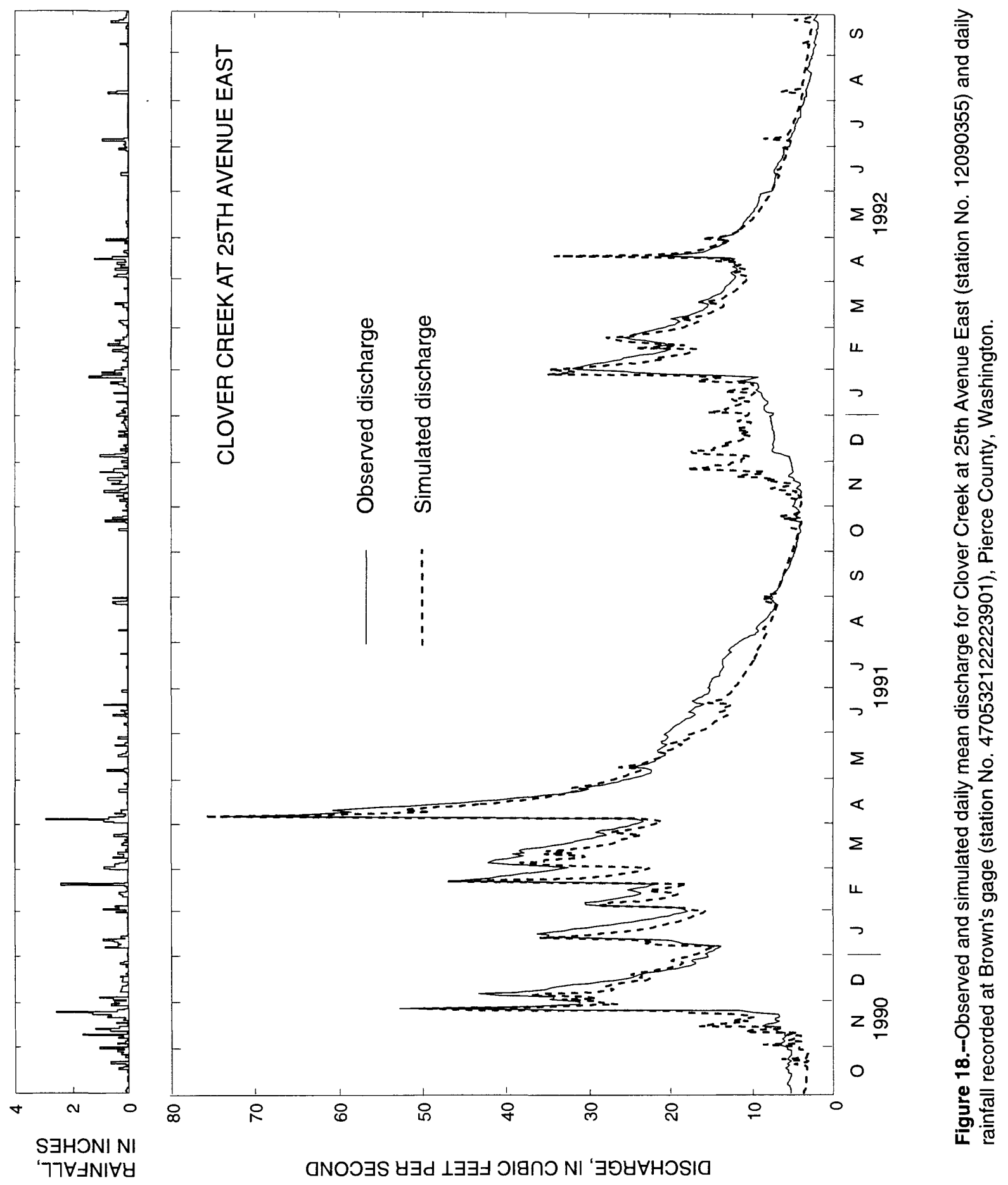




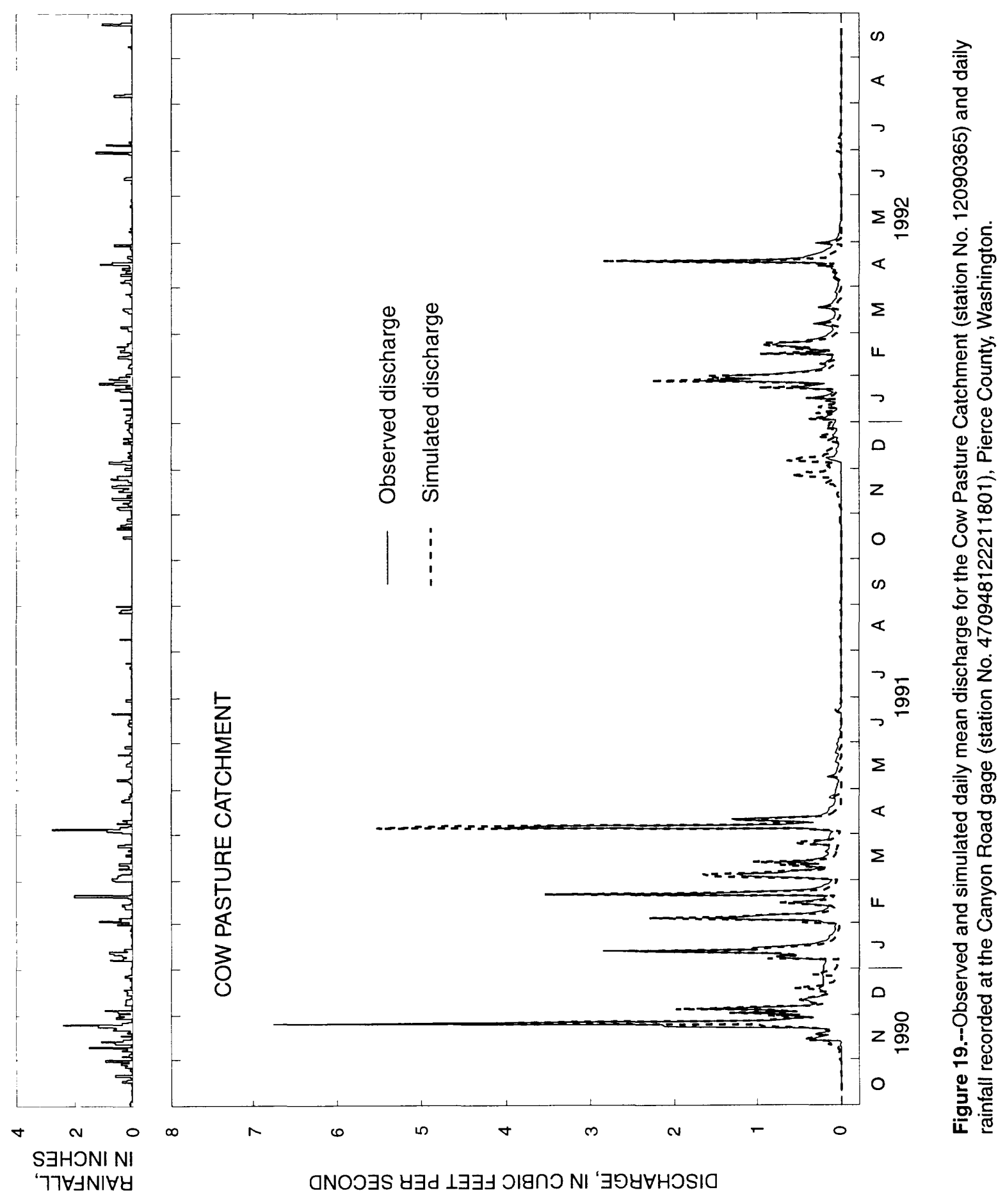




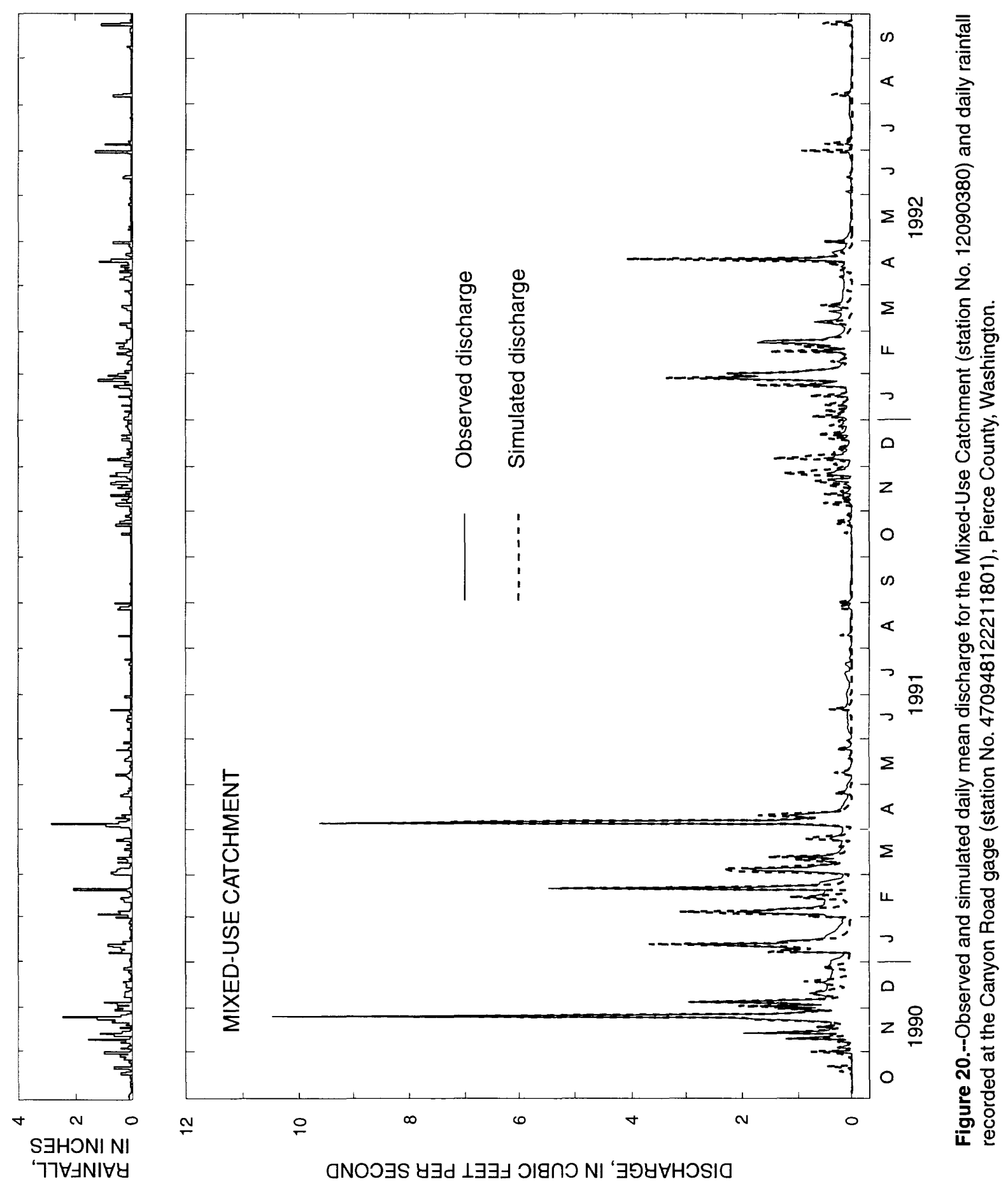




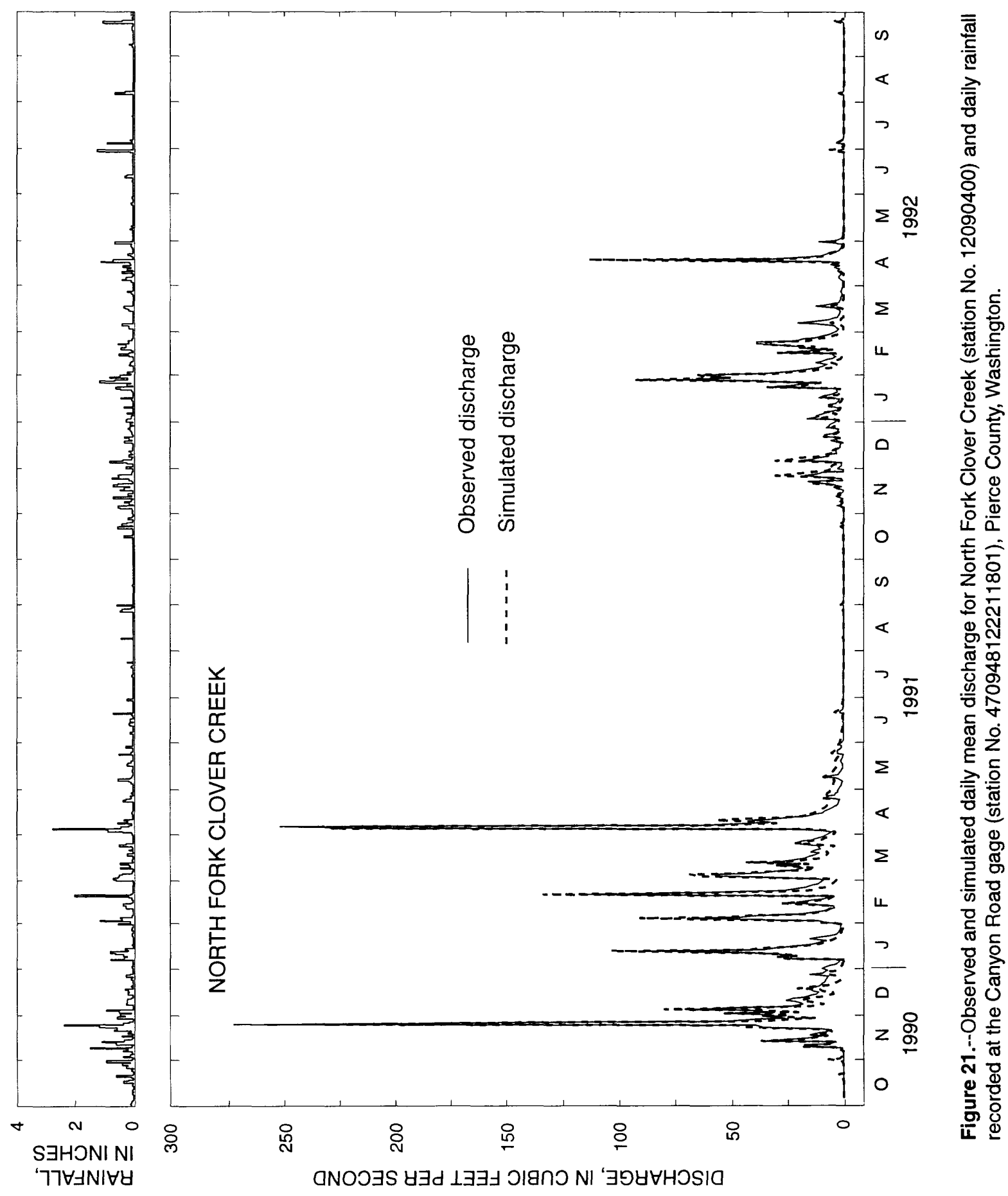




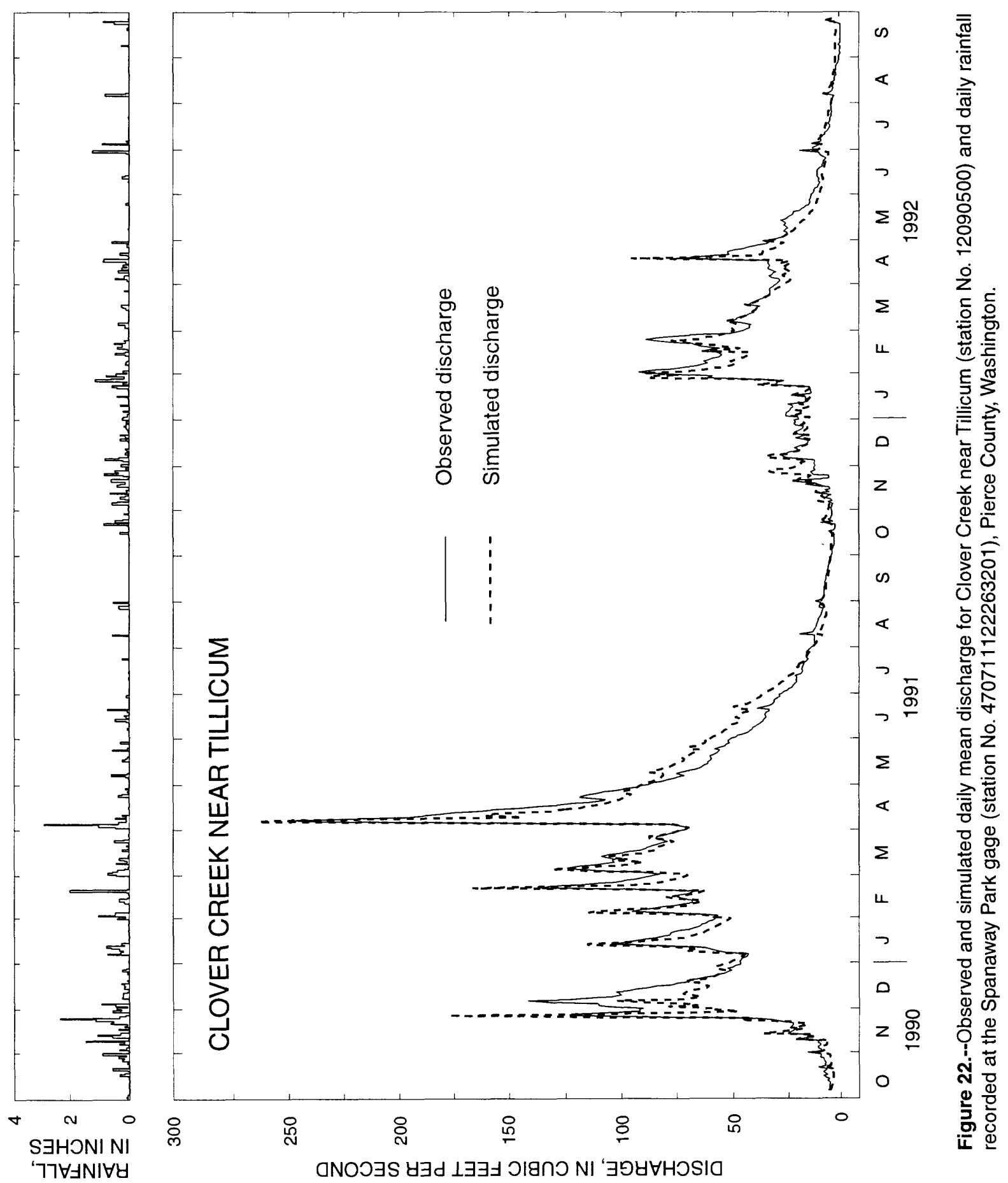




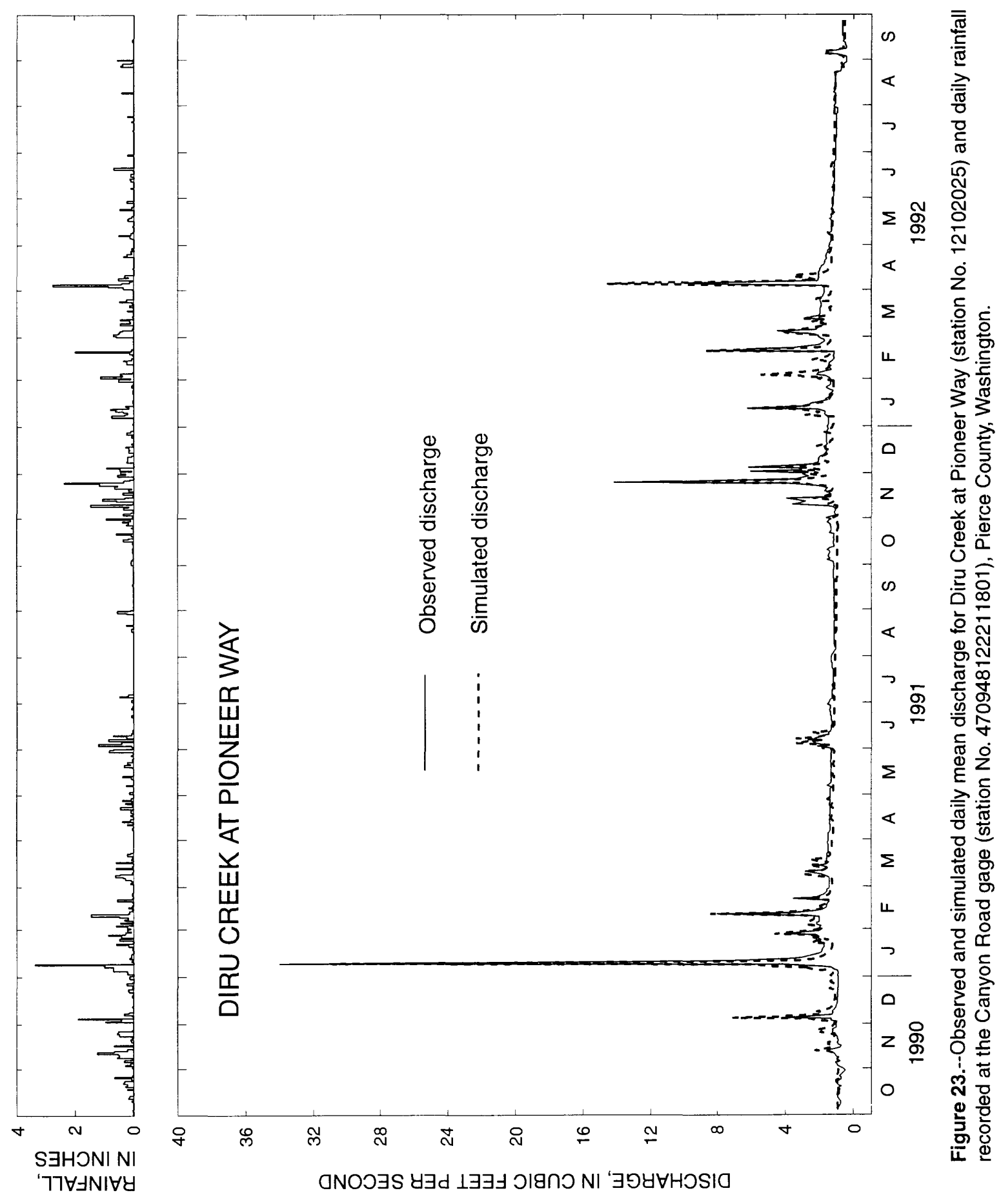




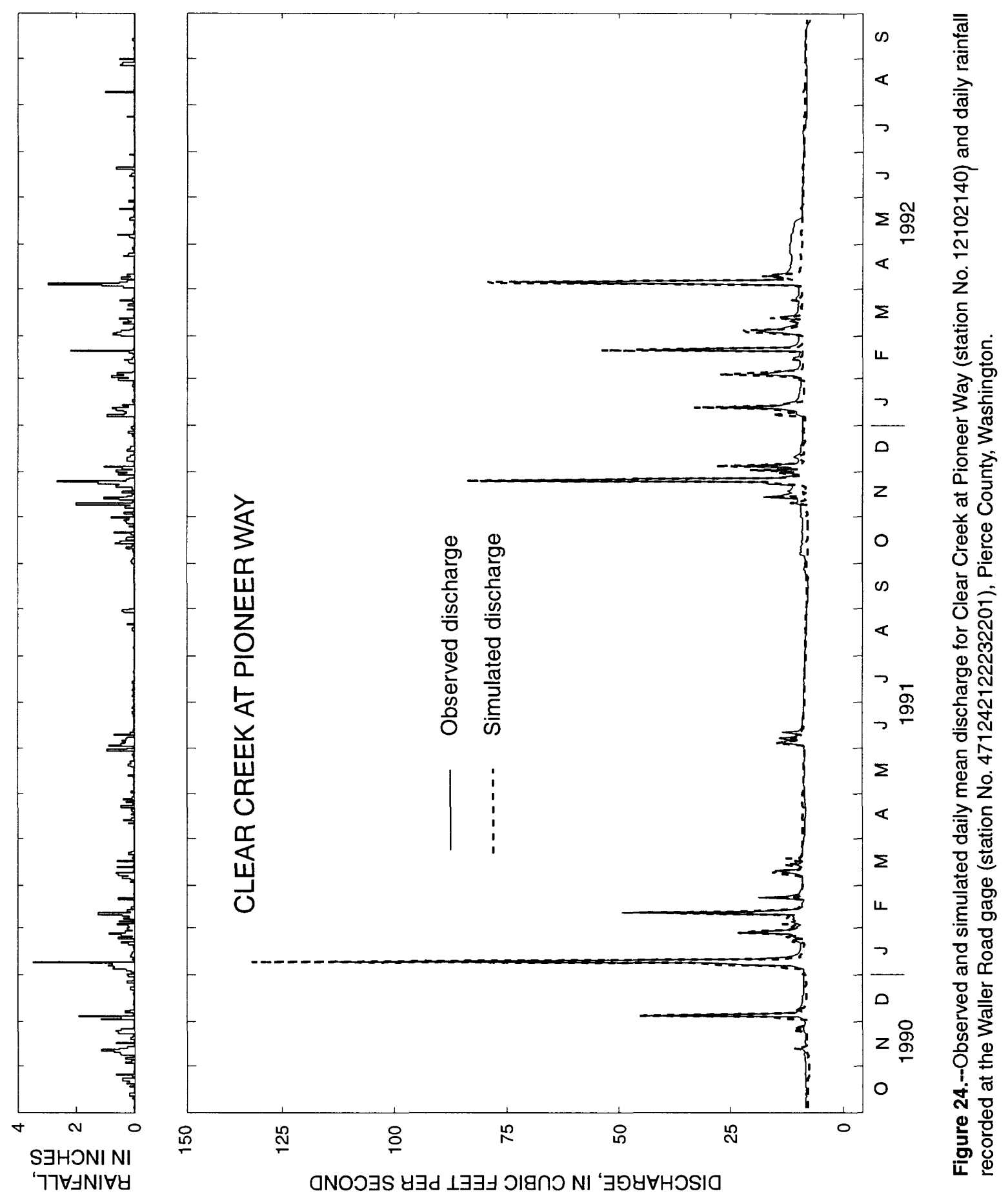




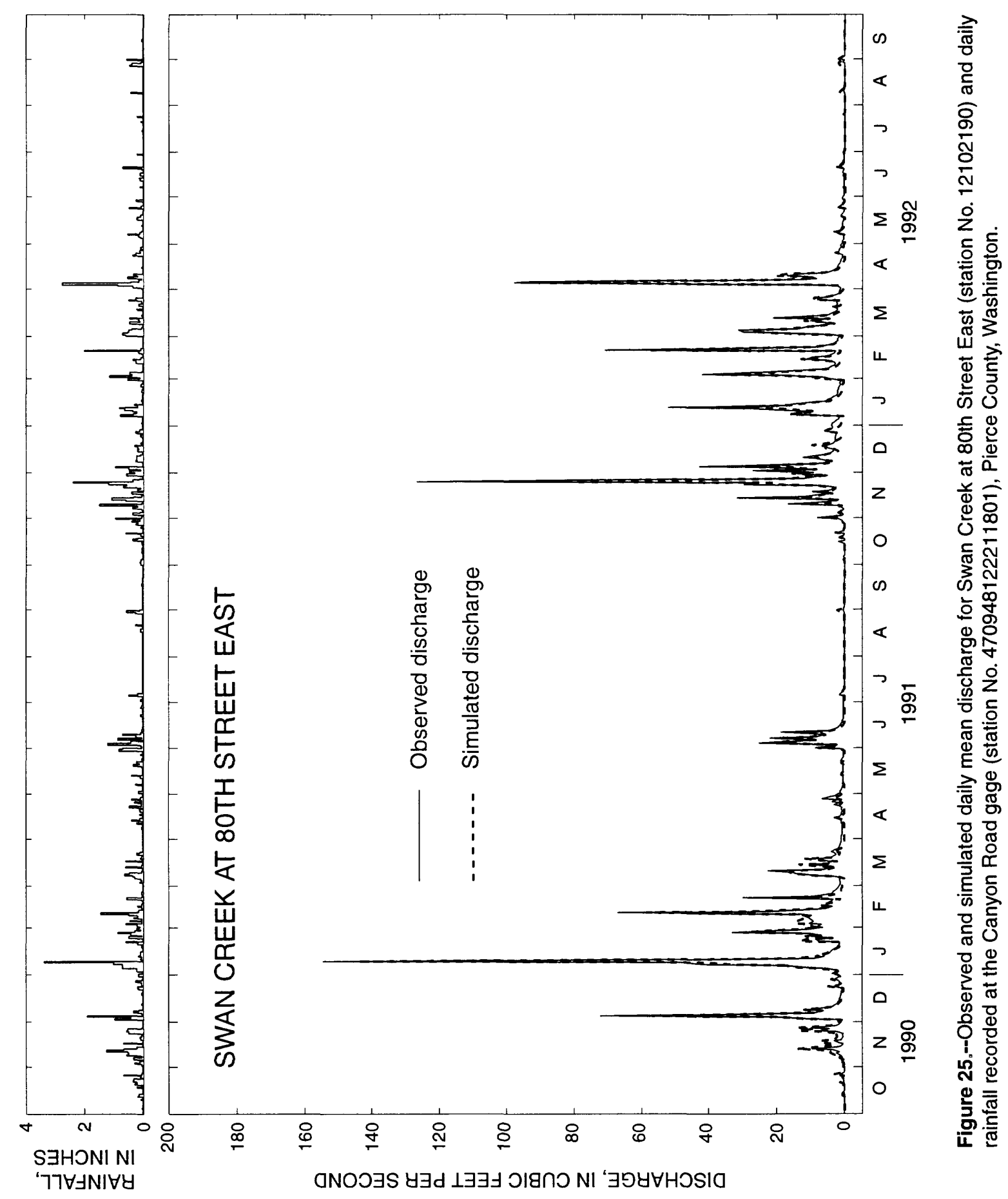




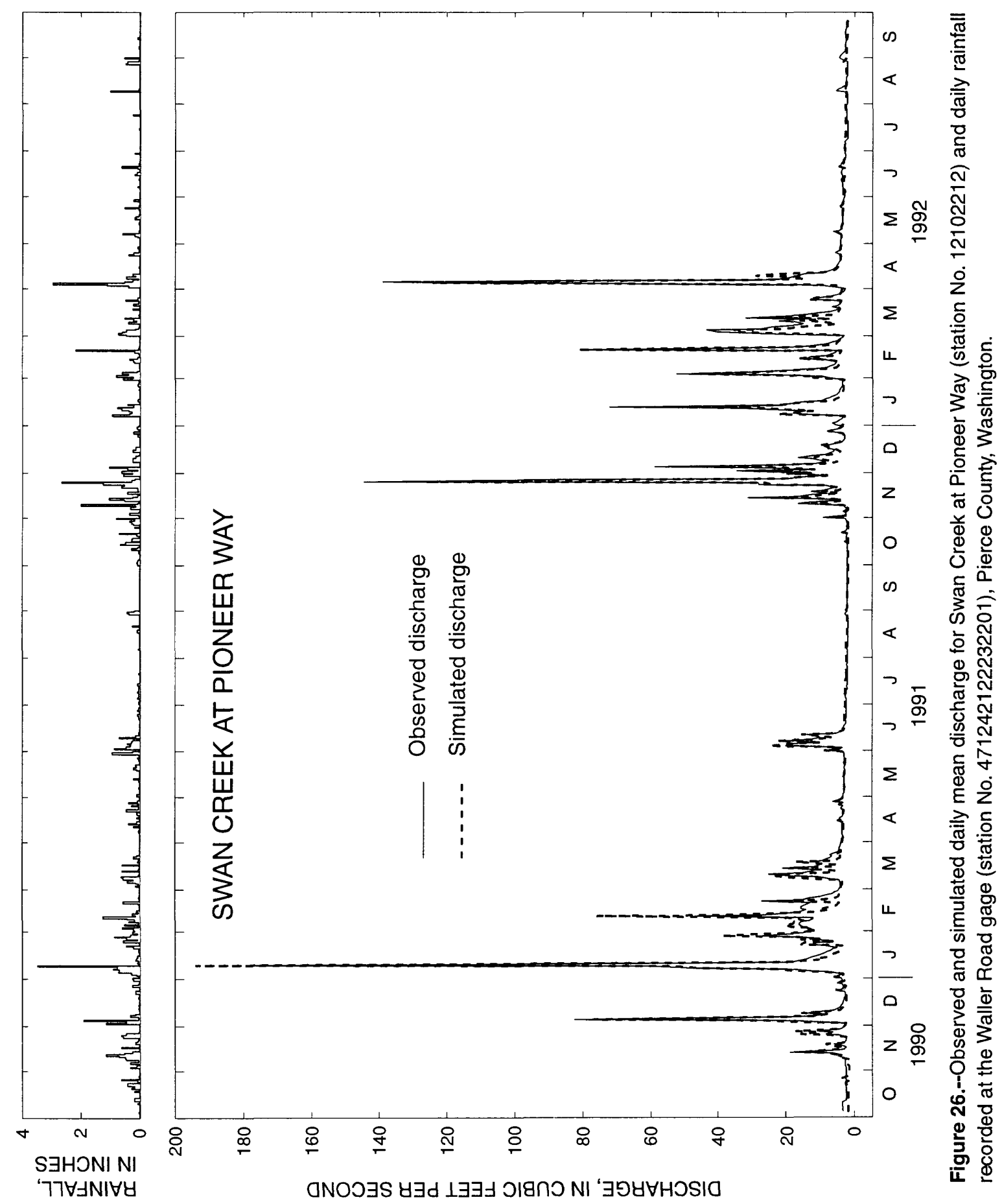



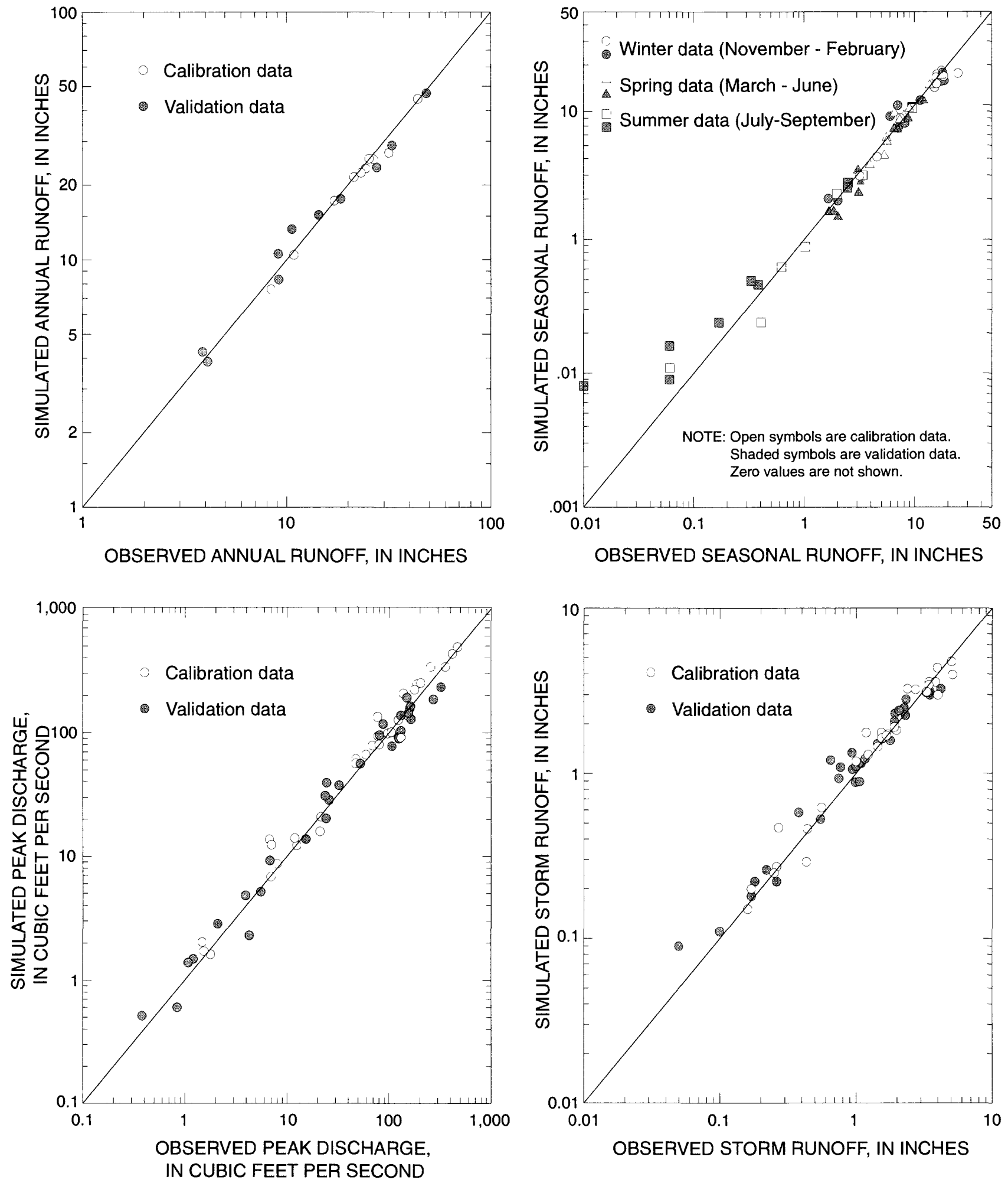

Figure 27.--Observed and simulated annual runoff, seasonal runoff, storm runoff, and peak discharge data for all of the continuous-recording stream-gage sites in the study area. 


\section{Peak Discharges and Storm Runoff Volumes}

Within a reasonable margin of error, the simulated peak discharges and storm volumes matched the observed peak discharges and storm volumes for most cases, and with the exception of several ground-water dominated storm hydrographs, the model reproduced the same general storm-discharge responses to rainfall that were observed. Several methods were used to compare simulated and observed discharges for the largest runoff events during the data-collection period. Comparisons were made of simulated and observed instantaneous peak discharges, in cubic feet per second, at all the streamflow sites for the three largest peak-flow storms of the calibration period and the three largest peak-flow storms of the validation period (tables 9 and 10), and comparisons were made of runoff volumes, in inches of runoff, at the continuous-recording sites for the same storms (table 9).

Selected storm hydrographs for several representative sites show how well the simulation models mimicked the shape of the storm hydrograph and how the streams responded to large rainfall events (figs. 28-31). The storm periods selected to compute runoff volumes included complete 24-hour intervals 3 to 7 days long, beginning and ending at midnight. The periods began on the day when medium to heavy rainfall began and ended a day or two after peak flows occurred. In table 10 , several discharge values are missing at the crest-stage gage sites because of malfunctions of the gage and-during the 1992 water yearbecause no large peak discharges allowed the water to reach the lowest part of the crest-stage stick (base-bolt elevation) and leave a mark. In these cases, it can only be stated that the peak discharge was less than the discharge determined for the base-bolt elevation. A summary of the comparison of peak discharges and storm runoff can be seen on figure 27.

Two-thirds of simulated peak discharges were within 23 percent of observed values (within 20 percent for the calibration period and 27 percent for the validation period), although differences as large as 66.2 percent were observed (tables 9 and 10). This extreme percent difference computed for the Cow Pasture Catchment represented a simulated discharge of only 4.5 cubic feet per second greater than the observed peak. During the calibration period, the greatest difference between simulated and observed peak discharge was 80 cubic feet per second at Swan Creek at Pioneer Way, which represented a simulated peak 22.2 percent less than the observed peak. For the validation period, the greatest peak discharge difference was 88 cubic feet per second (-27.2 percent difference), and the greatest percent difference was 65.0 percent ( 7.8 cubic feet per second discharge difference). The peak discharge differences shown on figure 27 are evenly distributed on either side of the 45 degree line, indicating litthe bias of the simulation model to undersimulate or oversimulate the peak discharges.

Two types of storm runoff responses, illustrated by their storm hydrographs (figs. 28-31), were found at stations at the headwaters and the mouths of two creeks: Swan Creek, a basin containing predominately glacial-till soils, and Clover Creek, a basin containing predominately glacial-outwash soils. The Swan Creek simulated and observed hydrographs (figs. 28 and 29) matched well, except for some sharp spikes in the observed record for Swan Creek at Pioneer that were not simulated by the Clear-Clarks Basin model; these peaks account for much of the peak discharge difference reported in table 9. The simulated peaks tended to occur slightly earlier than the observed peaks, but the general shapes were maintained. Swan Creek was more responsive to rainfall and produced more runoff per unit area than Clover Creek (figs. 30 and 31). For example, Swan Creek produced 3.41 inches of runoff for the April 2-6, 1991, storm, whereas Clover Creek produced only 0.44 inch. Clover Creek was much less responsive to storms, and the hydrographs had more rounded peaks than Swan Creek. Although the difference between simulated and observed peak discharges and runoff volumes were low for the two Clover Creek stations, in general the shapes of the storm hydrographs were not always accurately simulated. For example, the February 18-21 storm simulation closely matched the observed runoff volumes for both Clover Creek sites (see table 9: within 6.2 percent at 25th Avenue East, and 0 percent near Tillicum), but the simulated hydrograph shape is somewhat different from the observed (fig. 30). 
Differences between simulated and observed storm runoff (that is, total runoff during a storm) were a maximum of -1.18 inches, and two-thirds were less than 0.24 inch, with some bias for oversimulation during the 1992 water year. For the calibration period, the maximum runoff difference was -1.18 inches at the Suburban Catchment, representing simulated runoff that was 23.0 percent less than observed runoff; percent differences ranged from -32.6 to 74.1 percent. The 74.1 percent difference for the Diru Creek (station 12102025) represented only a 0.20 difference in inches of storm runoff. For the validation period, the maximum runoff difference was 0.97 inch $(-22.9$ percent difference, the largest negative percent difference), and the maximum percent difference was 84.6 percent (a 0.55 inch difference). Two thirds of the percent differences were within 19 percent of the observed storm volume. Data for the validation period for Clover Creek during the drier-than-normal 1992 water year showed that 16 of the 18 simulated runoff values exceeded the observed values.
Despite some of the inaccuracies, in general the model was successful in simulating storm runoff, it is valid to expect it to repeat the accuracy of simulation for similar conditions. The success of the simulations also supports the conclusion that the conceptual model was an accurate description of the important hydrologic processes for the study area. At locations where regional groundwater influences dominate the storm hydrograph (Spanaway Creek represented by stations 12090460,12090452 , 12090448; Morey Creek represented by station 12090480 , and the main stem of Clover Creek represented by stations 12090330, 12090355, 12090360, 12090430, 12090500, and 12090602), accurate simulation of peak flows and volumes can be expected, although the simulation of the timing of peak discharges or the duplication of hydrograph shapes may not always be as accurate as simulations for locations where regional ground-water discharge is not a large component of storm runoff. 
Table 9.--Observed and simulated storm runoff and peak discharge data for all continuous-recording stream-gaging stations in Pierce County, Washington

[ $\mathrm{ft}^{3} / \mathrm{s}$, cubic feet per second]

\begin{tabular}{|c|c|c|c|c|c|c|c|c|c|c|}
\hline \multirow{3}{*}{$\begin{array}{l}\text { Station } \\
\text { number }\end{array}$} & \multirow{3}{*}{$\begin{array}{l}\text { Date } \\
\text { of } \\
\text { storm }\end{array}$} & \multirow{3}{*}{$\begin{array}{l}\text { Date } \\
\text { of } \\
\text { peak }\end{array}$} & \multicolumn{4}{|c|}{ Storm runoff ${ }^{1}$} & \multicolumn{4}{|c|}{ Peak discharge ${ }^{2}$} \\
\hline & & & \multirow{2}{*}{$\begin{array}{l}\text { Ob- } \\
\text { served } \\
\text { runoff } \\
\text { (inches) }\end{array}$} & \multirow{2}{*}{$\begin{array}{l}\text { Simu- } \\
\text { lated } \\
\text { runoff } \\
\text { (inches) }\end{array}$} & \multicolumn{2}{|c|}{ Difference } & \multirow{2}{*}{$\begin{array}{l}\text { Ob- } \\
\text { served } \\
\text { runoff } \\
\left(\mathrm{ft}^{3} / \mathrm{s}\right)\end{array}$} & \multirow{2}{*}{$\begin{array}{l}\text { Simu- } \\
\text { lated } \\
\text { runoff } \\
\left(\mathrm{ft}^{3} / \mathrm{s}\right)\end{array}$} & \multicolumn{2}{|c|}{ Difference } \\
\hline & & & & & (inches) & Percent & & & $\left(\mathrm{ft}^{3} / \mathrm{s}\right)$ & Percent \\
\hline \multirow[t]{6}{*}{12090340} & $11 / 21-26 / 90$ & $11-24$ & 5.14 & 3.96 & -1.18 & -23.0 & 1.80 & 1.34 & -0.46 & -25.6 \\
\hline & $02 / 18-21 / 91$ & $02-19$ & 1.54 & 1.77 & 0.23 & 14.9 & 1.55 & 1.42 & -0.13 & -8.4 \\
\hline & $04 / 02-06 / 91$ & 04-04 & 3.47 & 3.58 & 0.11 & 3.2 & 1.50 & 1.69 & 0.19 & 12.7 \\
\hline & $11 / 16-21 / 91$ & $11-21$ & 0.38 & 0.58 & 0.20 & 52.6 & 0.38 & 0.51 & 0.13 & 34.2 \\
\hline & $01 / 27-02 / 01 / 92$ & $01-28$ & 2.34 & 2.81 & 0.47 & 20.1 & 0.84 & 0.60 & -0.24 & -28.6 \\
\hline & 04/16-18/92 & 04-17 & 0.93 & 1.34 & 0.41 & 44.1 & 1.20 & 1.48 & 0.28 & 23.3 \\
\hline \multirow[t]{6}{*}{12090355} & $11 / 21-26 / 90$ & $11-25$ & 0.17 & 0.20 & 0.03 & 17.6 & 59.9 & 54.8 & -5.1 & -8.5 \\
\hline & $02 / 18-21 / 91$ & $02-20$ & 0.16 & 0.15 & -0.01 & -6.2 & 47.9 & 50.6 & 2.7 & 5.6 \\
\hline & $04 / 02-06 / 91$ & 04-05 & 0.26 & 0.27 & 0.01 & 3.8 & 78.5 & 78.4 & -0.1 & -0.1 \\
\hline & $01 / 27-02 / 01 / 92$ & $01-31$ & 0.18 & 0.22 & 0.04 & 22.2 & 32.5 & 37.5 & 5.0 & 15.4 \\
\hline & $02 / 18-23 / 92$ & $02-21$ & 0.17 & 0.18 & 0.01 & 5.9 & 25.8 & 28.8 & 3.0 & 11.6 \\
\hline & $04 / 16-18 / 92$ & $04-17$ & 0.05 & 0.09 & 0.04 & 80.0 & 24.3 & 39.6 & 15.3 & 63.0 \\
\hline \multirow[t]{6}{*}{12090365} & $11 / 21-26 / 90$ & $11-24$ & 3.99 & 2.98 & -1.01 & -25.3 & 8.0 & 7.19 & -0.81 & -10.1 \\
\hline & $02 / 18-21 / 91$ & $02-19$ & 1.56 & 1.62 & 0.06 & 3.8 & 7.0 & 5.64 & -1.36 & -19.4 \\
\hline & $04 / 2-6 / 91$ & 04-05 & 2.39 & 3.25 & 0.86 & 36.0 & 6.8 & 11.3 & 4.5 & 66.2 \\
\hline & $01 / 27-02 / 01 / 92$ & $01-28$ & 1.93 & 2.30 & 0.37 & 19.2 & 2.10 & 2.85 & 0.75 & 35.7 \\
\hline & $02 / 18-23 / 92$ & $02-21$ & 0.94 & 1.06 & 0.12 & 12.8 & 1.08 & 1.39 & 0.31 & 28.7 \\
\hline & $04 / 16-18 / 92$ & $04-17$ & 1.00 & 1.10 & 0.10 & 10.0 & 5.54 & 5.14 & -0.40 & -7.2 \\
\hline \multirow[t]{6}{*}{12090380} & $11 / 21-26 / 90$ & $11-24$ & 3.83 & 3.57 & -0.26 & -6.8 & 21.3 & 13.1 & -8.2 & -38.5 \\
\hline & $02 / 18-21 / 91$ & $02-19$ & 1.67 & 1.70 & 0.03 & 1.8 & 12.6 & 10.1 & -2.5 & -19.8 \\
\hline & $04 / 02-06 / 91$ & 04-05 & 3.44 & 3.42 & -0.02 & -0.6 & 21.8 & 17.2 & -4.6 & -21.1 \\
\hline & $01 / 27-02 / 01 / 92$ & $01-28$ & 2.26 & 2.49 & 0.23 & 10.2 & 3.93 & 4.78 & 0.85 & 21.6 \\
\hline & $02 / 18-23 / 92$ & $02-21$ & 1.09 & 1.15 & 0.06 & 5.5 & 4.31 & 2.30 & -2.01 & -46.6 \\
\hline & $04 / 16-18 / 92$ & $04-17$ & 0.65 & 1.20 & 0.55 & 84.6 & 6.79 & 9.26 & 2.47 & 36.4 \\
\hline \multirow[t]{6}{*}{12090400} & $11 / 21-26 / 90$ & $11-24$ & 3.30 & 3.07 & -0.23 & -7.0 & 423.0 & 356.0 & -67.0 & -15.8 \\
\hline & $02 / 18-21 / 91$ & $02-19$ & 1.45 & 1.46 & 0.01 & 0.7 & 191.0 & 205.0 & 14.0 & 7.3 \\
\hline & $04 / 2-06 / 91$ & $04-05$ & 3.33 & 3.12 & -0.21 & -6.3 & 474.0 & 402.0 & -72.0 & -15.2 \\
\hline & $01 / 27-02 / 01 / 92$ & $01-31$ & 1.91 & 2.07 & 0.16 & 8.4 & 88.0 & 118.0 & 30.0 & 34.1 \\
\hline & $02 / 18-23 / 92$ & $02-21$ & 0.99 & 0.88 & -0.11 & -11.1 & 52.2 & 56.0 & 3.8 & 7.3 \\
\hline & $04 / 16-18 / 92$ & $04-17$ & 0.75 & 0.93 & 0.18 & 24.0 & 151.0 & 192.0 & 41.0 & 27.2 \\
\hline \multirow[t]{6}{*}{12090500} & $11 / 29-12 / 5 / 90$ & $12-05$ & 0.43 & 0.29 & -0.14 & -32.6 & 157.0 & 112.0 & -45.0 & -28.7 \\
\hline & $02 / 18-21 / 91$ & $02-20$ & 0.25 & 0.25 & 0.00 & 0.0 & 141.0 & 172.0 & 31.0 & 22.0 \\
\hline & $04 / 02-06 / 91$ & $04-05$ & 0.44 & 0.46 & 0.02 & 4.5 & 259.0 & 283.0 & 24.0 & 9.3 \\
\hline & $01 / 27-02 / 01 / 92$ & $01-31$ & 0.22 & 0.26 & 0.04 & 18.2 & 123.0 & 92.9 & -30.1 & -24.5 \\
\hline & $02 / 18-23 / 92$ & $02-21$ & 0.26 & 0.22 & -0.04 & -15.4 & 106.0 & 78.2 & -27.8 & -26.2 \\
\hline & $04 / 16-18 / 92$ & 04-17 & 0.10 & 0.11 & 0.01 & 10.0 & 130.0 & 104.0 & -26.0 & -20.0 \\
\hline
\end{tabular}


Table 9.--Observed and simulated storm runoff and peak discharge data for all continuous-recording stream-gaging stations in Pierce County, Washington--Continued

\begin{tabular}{|c|c|c|c|c|c|c|c|c|c|c|}
\hline \multirow{3}{*}{$\begin{array}{l}\text { Station } \\
\text { number }\end{array}$} & \multirow{3}{*}{$\begin{array}{l}\text { Date } \\
\text { of } \\
\text { storm }\end{array}$} & \multirow{3}{*}{$\begin{array}{l}\text { Date } \\
\text { of } \\
\text { peak }\end{array}$} & \multicolumn{4}{|c|}{ Storm runoff ${ }^{1}$} & \multicolumn{4}{|c|}{ Peak discharge ${ }^{2}$} \\
\hline & & & \multirow{2}{*}{$\begin{array}{l}\text { Ob- } \\
\text { served } \\
\text { runoff } \\
\text { (inches) }\end{array}$} & \multirow{2}{*}{$\begin{array}{l}\text { Simu- } \\
\text { lated } \\
\text { runoff } \\
\text { (inches) }\end{array}$} & \multicolumn{2}{|c|}{ Difference } & \multirow{2}{*}{$\begin{array}{l}\text { Ob- } \\
\text { served } \\
\text { runoff } \\
\left(\mathrm{ft}^{3} / \mathrm{s}\right)\end{array}$} & \multirow{2}{*}{$\begin{array}{l}\text { Simu- } \\
\text { lated } \\
\text { runoff } \\
\left(\mathrm{ft}^{3} / \mathrm{s}\right)\end{array}$} & \multicolumn{2}{|c|}{ Difference } \\
\hline & & & & & (inches) & Percent & & & $\left(\mathrm{ft}^{3} / \mathrm{s}\right)$ & Percent \\
\hline \multirow[t]{6}{*}{12102025} & $12 / 02-05 / 89$ & $12-04$ & 0.27 & 0.47 & 0.20 & 74.1 & 7.1 & 10.2 & 3.1 & 43.7 \\
\hline & $01 / 05-10 / 90$ & 01-09 & 1.72 & 1.72 & 0.00 & 0.0 & 48.0 & 46.7 & -1.3 & -2.7 \\
\hline & $02 / 7-11 / 90$ & $02-10$ & 0.56 & 0.62 & 0.06 & 10.7 & 12.0 & 11.6 & -0.4 & -3.3 \\
\hline & $11 / 21-26 / 90$ & $11-24$ & 1.06 & 0.89 & -0.17 & -16.0 & 24.0 & 20.2 & -3.8 & -15.8 \\
\hline & $02 / 18-21 / 91$ & $02-19$ & 0.55 & 0.53 & -0.02 & -3.6 & 15.3 & 13.8 & -1.5 & -9.8 \\
\hline & $04 / 02-06 / 91$ & 04-04 & 0.77 & 1.09 & 0.32 & 41.6 & 23.6 & 31.1 & 7.5 & 31.8 \\
\hline \multirow{6}{*}{12102140} & $12 / 02-05 / 89$ & $12-04$ & 1.00 & 1.18 & 0.18 & 18.0 & 70.0 & 64.8 & -5.2 & -7.4 \\
\hline & $01 / 05-10 / 90$ & 01-09 & 2.76 & 3.23 & 0.47 & 17.0 & 180.0 & 185.0 & 5.0 & 2.8 \\
\hline & $02 / 07-11 / 90$ & $02-10$ & 1.23 & 1.30 & 0.07 & 5.7 & 81.0 & 66.4 & -14.6 & -18.0 \\
\hline & $11 / 21-26 / 90$ & $11-24$ & 2.32 & 2.25 & -0.07 & -3.0 & 130.0 & 139.0 & 9.0 & 6.9 \\
\hline & $02 / 18-21 / 91$ & 02-19 & 1.16 & 1.22 & 0.06 & 5.2 & 80.6 & 95.4 & 14.8 & 18.4 \\
\hline & $04 / 02-06 / 91$ & 04-04 & 2.07 & 2.41 & 0.34 & 16.4 & 160.0 & 160.0 & 0.0 & 0.0 \\
\hline \multirow[t]{6}{*}{12102190} & $12 / 02-05 / 89$ & $12-04$ & 1.98 & 1.83 & -0.15 & -7.6 & 98.6 & 81.7 & -16.9 & -17.1 \\
\hline & $01 / 05-10 / 90$ & 01-09 & 5.04 & 4.75 & -0.29 & -5.8 & 206.0 & 208.0 & 2.0 & 1.0 \\
\hline & $02 / 07-11 / 90$ & $02-10$ & 1.92 & 1.92 & 0.00 & 0.0 & 107.0 & 83.9 & -23.1 & -21.6 \\
\hline & $11 / 21-26 / 90$ & $11-24$ & 4.24 & 3.27 & -0.97 & -22.9 & 164.0 & 130.0 & -34.0 & -20.7 \\
\hline & $02 / 18-21 / 91$ & 02-19 & 1.78 & 1.59 & -0.19 & -10.7 & 125.0 & 93.9 & -31.1 & -24.9 \\
\hline & $04 / 02-06 / 91$ & 04-04 & 3.48 & 3.14 & -0.34 & -9.8 & 163.0 & 164.0 & 1.0 & 0.6 \\
\hline \multirow[t]{6}{*}{12102212} & $12 / 02-05 / 89$ & $12-04$ & 1.55 & 1.64 & 0.09 & 5.8 & 125.0 & 106.0 & -19.0 & -15.2 \\
\hline & $01 / 05-10 / 90$ & 01-09 & 3.98 & 4.34 & 0.36 & 9.0 & 360.0 & 280.0 & -80.0 & -22.2 \\
\hline & $02 / 07-11 / 90$ & $02-10$ & 1.19 & 1.77 & 0.58 & 48.7 & 78.2 & 111.0 & 32.8 & 41.9 \\
\hline & $11 / 21-26 / 90$ & $11-24$ & 3.48 & 3.00 & -0.48 & -13.8 & 271.0 & 186.0 & -85.0 & -31.4 \\
\hline & $02 / 18-21 / 91$ & 02-19 & 1.45 & 1.52 & 0.07 & 4.8 & 155.0 & 144.0 & -11.0 & -7.1 \\
\hline & $04 / 02-06 / 91$ & 04-04 & 3.41 & 3.09 & -0.32 & -9.4 & 323.0 & 235.0 & -88.0 & -27.2 \\
\hline
\end{tabular}

${ }^{1}$ Storm runoff data are the total of daily streamflow volumes for the period of each storm.

${ }^{2}$ Peak discharge data are the maximum instataneous discharge for each storm. 
Table 10.--Observed and simulated peak discharge data for all crest-stage stations, Pierce County, Washington $\left[\mathrm{ft}^{3} / \mathrm{s}\right.$, cubic feet per second; <, less than; --, indicates missing data]

\begin{tabular}{|c|c|c|c|c|c|}
\hline \multirow{3}{*}{$\begin{array}{l}\text { Station } \\
\text { number }\end{array}$} & \multirow{3}{*}{$\begin{array}{l}\text { Date } \\
\text { of } \\
\text { peak }\end{array}$} & \multicolumn{4}{|c|}{ Peak discharge } \\
\hline & & \multirow{2}{*}{$\begin{array}{l}\text { Observed } \\
\left(\mathrm{ft}^{3} / \mathrm{s}\right)\end{array}$} & \multirow{2}{*}{$\begin{array}{l}\text { Simulated } \\
\left(\mathrm{ft}^{3} / \mathrm{s}\right)\end{array}$} & \multicolumn{2}{|c|}{ Difference } \\
\hline & & & & $\left(\mathrm{ft}^{3} / \mathrm{s}\right)$ & Percent \\
\hline \multirow[t]{6}{*}{12090330} & $11-25-90$ & 14.0 & 18.9 & 4.9 & 35.0 \\
\hline & $02-20-91$ & -- & 17.4 & -- & -- \\
\hline & $04-05-91$ & 26.0 & 25.5 & -0.5 & -1.9 \\
\hline & $01-31-92$ & $<13.0$ & 17.4 & -- & -- \\
\hline & $02-21-92$ & $<13.0$ & 13.8 & -- & -- \\
\hline & $04-17-92$ & $<13.0$ & 10.9 & -- & -- \\
\hline \multirow[t]{6}{*}{12090360} & $01-15-91$ & 12.0 & 11.6 & -0.4 & -3.3 \\
\hline & $02-21-91$ & 20.0 & 25.6 & 5.6 & 28.0 \\
\hline & $04-05-91$ & 76.0 & 73.1 & -2.9 & -3.8 \\
\hline & $02-21-92$ & 6.4 & 6.24 & -0.16 & -2.5 \\
\hline & $04-17-92$ & 7.7 & 10.6 & 2.9 & 37.7 \\
\hline & ${ }^{\mathrm{I}} 05-10-92$ & 6.9 & 3.71 & -3.19 & -46.2 \\
\hline \multirow[t]{6}{*}{12090370} & $11-24-90$ & -- & 118.0 & -- & -- \\
\hline & $02-19-91$ & 91.0 & 72.1 & -18.9 & -20.8 \\
\hline & $04-05-91$ & 130.0 & 156.0 & 26.0 & 20.0 \\
\hline & $01-28-92$ & 42.0 & 41.2 & -0.8 & -1.9 \\
\hline & $02-21-92$ & -- & 18.8 & -- & -- \\
\hline & $04-17-92$ & 72.0 & 61.9 & -10.1 & -14.0 \\
\hline \multirow[t]{6}{*}{12090395} & $11-24-90$ & 258.0 & 230.0 & -28.0 & -10.9 \\
\hline & $02-19-91$ & 111.0 & 135.0 & 24.0 & 21.6 \\
\hline & 04-05-91 & -- & 264.0 & -- & -- \\
\hline & $01-23-92$ & 39.0 & 30.2 & -8.8 & -22.6 \\
\hline & $01-28-92$ & 79.0 & 76.8 & -2.2 & -2.7 \\
\hline & $04-17-92$ & 103.0 & 129.0 & 26.0 & 25.2 \\
\hline \multirow[t]{6}{*}{12090430} & $11-25-90$ & 116.0 & 144.0 & 28.0 & 24.1 \\
\hline & $02-19-91$ & 107.0 & 94.9 & -12.1 & -11.3 \\
\hline & $04-05-91$ & 222.0 & 218.0 & -4.0 & -1.8 \\
\hline & $01-28-92$ & 53.0 & 55.9 & 2.9 & 5.5 \\
\hline & $02-21-92$ & 36.0 & 30.7 & -5.3 & -14.7 \\
\hline & $04-17-92$ & 76.0 & 76.6 & 0.6 & 0.8 \\
\hline \multirow[t]{6}{*}{12090448} & $02-20-91$ & 14.0 & 17.7 & 3.7 & 26.4 \\
\hline & $04-05-91$ & 30.0 & 25.1 & -4.9 & -16.3 \\
\hline & $04-14-91$ & 26.0 & 22.4 & -3.6 & -13.8 \\
\hline & $01-31-92$ & $<10.0$ & 10.7 & -- & -- \\
\hline & $02-21-92$ & $<10.0$ & 11.5 & -- & -- \\
\hline & $04-17-92$ & 6.5 & 6.81 & 0.31 & 4.8 \\
\hline
\end{tabular}


Table 10.--Observed and simulated peak discharge data for all crest-stage stations, Pierce County, Wash.--Continued

\begin{tabular}{|c|c|c|c|c|c|}
\hline \multirow{3}{*}{$\begin{array}{l}\text { Station } \\
\text { number }\end{array}$} & \multirow{3}{*}{$\begin{array}{l}\text { Date } \\
\text { of } \\
\text { peak }\end{array}$} & \multicolumn{4}{|c|}{ Peak discharge } \\
\hline & & \multirow{2}{*}{$\begin{array}{l}\text { Observed } \\
\left(\mathrm{ft}^{3} / \mathrm{s}\right)\end{array}$} & \multirow{2}{*}{$\begin{array}{l}\text { Simulated } \\
\left(\mathrm{ft}^{3} / \mathrm{s}\right)\end{array}$} & \multicolumn{2}{|c|}{ Difference } \\
\hline & & & & $\left(\mathrm{ft}^{3} / \mathrm{s}\right)$ & Percent \\
\hline \multirow[t]{6}{*}{12090452} & $02-20-91$ & 47.0 & 47.9 & 0.9 & 1.9 \\
\hline & $04-05-91$ & 64.0 & 67.0 & 3.0 & 4.7 \\
\hline & $04-14-91$ & 65.0 & 47.0 & -18.0 & -27.7 \\
\hline & $01-31-92$ & 23.0 & 28.8 & 5.8 & 25.2 \\
\hline & $02-22-92$ & 25.0 & 31.6 & 6.6 & 26.4 \\
\hline & $04-17-92$ & 24.0 & 26.4 & 2.4 & 10.0 \\
\hline \multirow[t]{6}{*}{12090460} & ${ }^{2} 03-05-91$ & 37.7 & 37.4 & -0.3 & -0.8 \\
\hline & $04-05-91$ & 48.0 & 70.8 & 22.8 & 47.5 \\
\hline & $04-15-91$ & 58.0 & 40.4 & -17.6 & -30.3 \\
\hline & $01-31-92$ & 21.0 & 27.2 & 6.2 & 29.5 \\
\hline & $02-22-92$ & 23.0 & 28.5 & 5.5 & 23.9 \\
\hline & $03-17-92$ & 20.0 & 20.7 & 0.7 & 3.5 \\
\hline \multirow[t]{6}{*}{12090480} & ${ }^{2} 02-20-91$ & 8.6 & 9.8 & 1.2 & 14.0 \\
\hline & 03-03-91 & 10.0 & 10.7 & 0.7 & 7.0 \\
\hline & $04-05-91$ & 13.0 & 18.2 & 5.2 & 40.0 \\
\hline & 02-03-92 & 5.6 & 6.82 & 1.22 & 21.8 \\
\hline & $02-22-92$ & 5.9 & 8.44 & 2.54 & 43.1 \\
\hline & $04-17-92$ & 8.0 & 11.1 & 3.1 & 38.8 \\
\hline \multirow[t]{6}{*}{12090602} & $12-05-90$ & -- & 114.0 & -- & -- \\
\hline & $02-20-91$ & 192.0 & 174.0 & -18.0 & -9.4 \\
\hline & $04-05-91$ & 357.0 & 286.0 & -71.0 & -19.9 \\
\hline & $01-31-92$ & 121.0 & 106.0 & -15.0 & -12.4 \\
\hline & $02-22-92$ & -- & 83.0 & -- & -- \\
\hline & $04-17-92$ & 150.0 & 111.0 & -39.0 & -26.0 \\
\hline \multirow[t]{6}{*}{12102040} & $12-04-89$ & 7.0 & 7.32 & 0.32 & 4.6 \\
\hline & $01-09-90$ & 19.0 & 22.8 & 3.8 & 20.0 \\
\hline & $02-10-90$ & 9.0 & 8.36 & -0.64 & -7.1 \\
\hline & $11-24-90$ & 13.0 & 13.4 & 0.40 & 3.1 \\
\hline & $02-19-91$ & 7.0 & 7.80 & 0.80 & 11.4 \\
\hline & 04-05-91 & 13.0 & 16.8 & 3.8 & 29.2 \\
\hline \multirow[t]{6}{*}{12102050} & $12-04-89$ & 7.5 & 8.26 & 0.76 & 10.1 \\
\hline & $01-09-90$ & 22.0 & 21.0 & -1.0 & -4.5 \\
\hline & $02-10-90$ & 9.5 & 8.38 & -1.12 & -11.8 \\
\hline & $11-24-90$ & 13.0 & 13.6 & 0.6 & 4.6 \\
\hline & $02-19-91$ & 6.5 & 10.6 & 4.1 & 63.1 \\
\hline & $04-05-91$ & 13.0 & 16.4 & 3.4 & 26.2 \\
\hline
\end{tabular}


Table 10.--Observed and simulated peak discharge data for all crest-stage stations, Pierce County, Wash.--Continued

\begin{tabular}{|c|c|c|c|c|c|}
\hline \multirow{3}{*}{$\begin{array}{l}\text { Station } \\
\text { number }\end{array}$} & \multirow{3}{*}{$\begin{array}{l}\text { Date } \\
\text { of } \\
\text { peak }\end{array}$} & \multicolumn{4}{|c|}{ Peak discharge } \\
\hline & & \multirow{2}{*}{$\begin{array}{l}\text { Observed } \\
\left(\mathrm{ft}^{3} / \mathrm{s}\right)\end{array}$} & \multirow{2}{*}{$\begin{array}{l}\text { Simulated } \\
\left(\mathrm{ft}^{3} / \mathrm{s}\right)\end{array}$} & \multicolumn{2}{|c|}{ Difference } \\
\hline & & & & $\left(\mathrm{ft}^{3} / \mathrm{s}\right)$ & Percent \\
\hline \multirow[t]{6}{*}{12102105} & $12-04-89$ & 17.0 & 15.3 & -1.7 & -10.0 \\
\hline & $01-09-90$ & 52.0 & 41.4 & -10.6 & -20.4 \\
\hline & $02-10-90$ & 18.0 & 14.9 & -3.1 & -17.2 \\
\hline & $11-24-90$ & 44.0 & 23.8 & -20.2 & -45.9 \\
\hline & $02-19-91$ & 23.0 & 19.0 & -4.0 & -17.4 \\
\hline & $04-05-91$ & 39.0 & 31.7 & -7.3 & -18.7 \\
\hline \multirow[t]{6}{*}{12102112} & $12-04-89$ & 11.0 & 8.87 & -2.13 & -19.4 \\
\hline & $01-09-90$ & 25.1 & 28.6 & 3.5 & 13.9 \\
\hline & $02-10-90$ & 10.6 & 10.0 & -0.6 & -5.7 \\
\hline & $11-24-90$ & -- & 14.5 & -- & -- \\
\hline & $02-19-91$ & 10.3 & 8.80 & -1.50 & -14.6 \\
\hline & $04-05-91$ & 14.0 & 20.4 & 6.4 & 45.7 \\
\hline \multirow[t]{6}{*}{12102115} & $12-04-89$ & 36.0 & 34.9 & -1.10 & -3.1 \\
\hline & 01-09-90 & 60.0 & 74.7 & 14.7 & 24.5 \\
\hline & $02-10-90$ & 43.0 & 36.6 & -6.4 & -14.9 \\
\hline & $11-24-90$ & 54.0 & 47.2 & -6.8 & -12.6 \\
\hline & $02-19-91$ & 33.0 & 33.3 & 0.3 & 0.9 \\
\hline & $04-05-91$ & 55.0 & 56.0 & 1.0 & 1.9 \\
\hline \multirow[t]{6}{*}{12102145} & $12-04-89$ & 15.0 & 14.3 & -0.7 & -4.7 \\
\hline & $01-09-90$ & 59.0 & 57.7 & -1.3 & -2.2 \\
\hline & $02-10-90$ & 13.0 & 14.9 & 1.9 & 14.6 \\
\hline & $11-24-90$ & 29.0 & 33.5 & 4.5 & 15.5 \\
\hline & $02-19-91$ & 12.0 & 19.8 & 7.8 & 65.0 \\
\hline & $04-05-91$ & 38.0 & 37.8 & -0.2 & -0.5 \\
\hline \multirow[t]{6}{*}{12102180} & $12-04-89$ & 110.0 & 58.9 & -51.1 & -46.5 \\
\hline & 01-09-90 & 200.0 & 158.0 & -42.0 & -21.0 \\
\hline & $02-10-90$ & 110.0 & 56.4 & -53.6 & -48.7 \\
\hline & $11-24-90$ & -- & 92.9 & -- & -- \\
\hline & $02-19-91$ & -- & 78.4 & -- & -- \\
\hline & $04-05-91$ & -- & 127.0 & -- & -- \\
\hline \multirow[t]{6}{*}{12102200} & $12-04-89$ & 95.0 & 84.6 & -10.4 & -10.9 \\
\hline & $01-09-90$ & 238.0 & 218.0 & -20.0 & -8.4 \\
\hline & $02-10-90$ & 105.0 & 87.3 & -17.7 & -16.9 \\
\hline & $11-24-90$ & 162.0 & 138.0 & -24.0 & -14.8 \\
\hline & $02-19-91$ & 98.0 & 99.6 & 1.6 & 1.6 \\
\hline & $04-05-91$ & 171.0 & 174.0 & 3.0 & 1.8 \\
\hline
\end{tabular}

${ }^{1}$ Sewer construction crew was observed to be pumping water into the Clover Creek from 05-10-92 to 05-20-92; that may have influenced the peak flow.

${ }^{2}$ Streamflow gage was installed on this date. Observed and simulated discharge are at the time of installation shortly after the simulated peak discharge. 

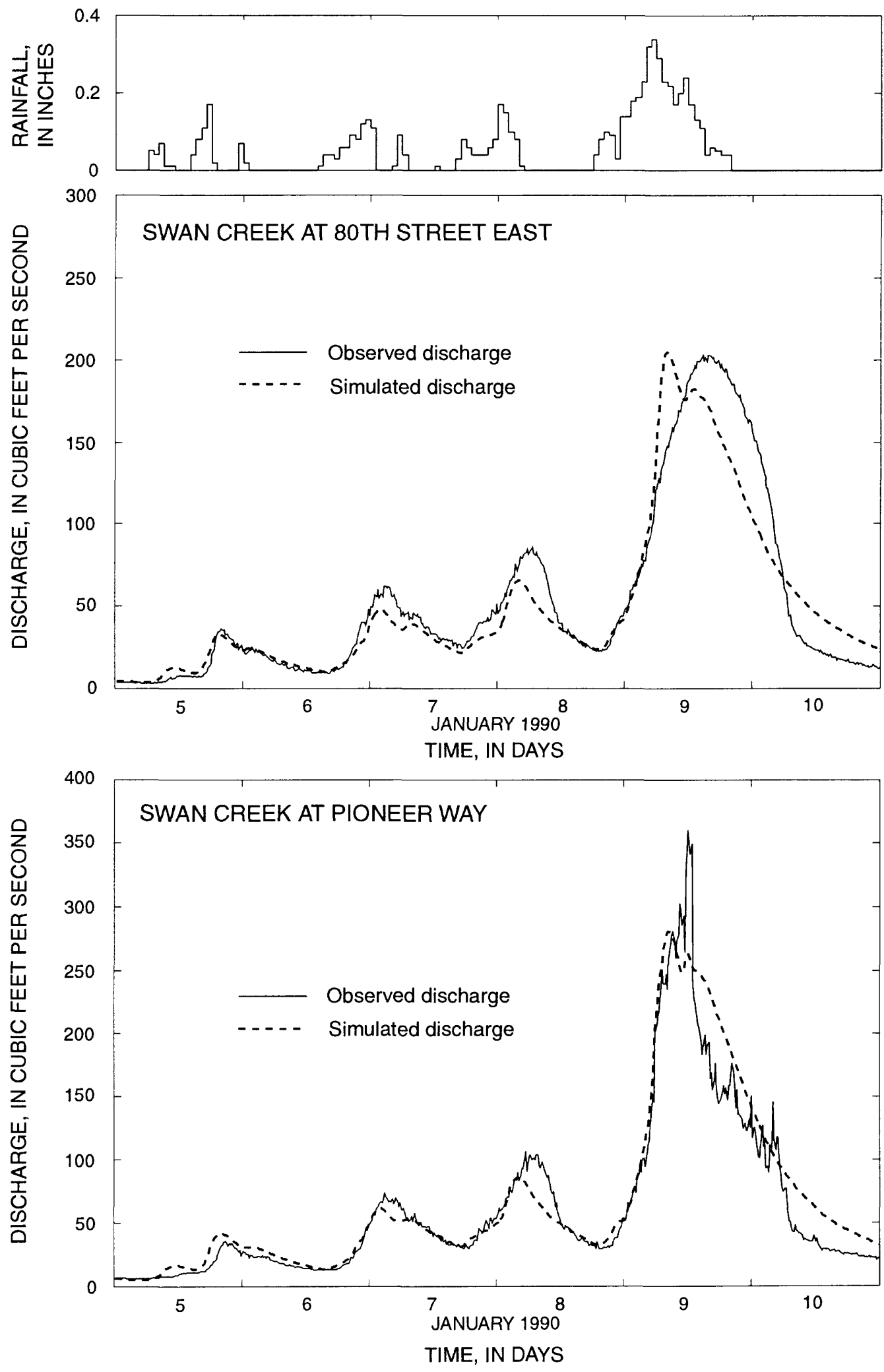

Figure 28.--Observed and simulated discharge at Swan Creek at 80th Street East and Swan Creek at Pioneer Way and rainfall recorded at the Canyon Road gage for the January 5-10, 1990, storm, Pierce County, Washington. 

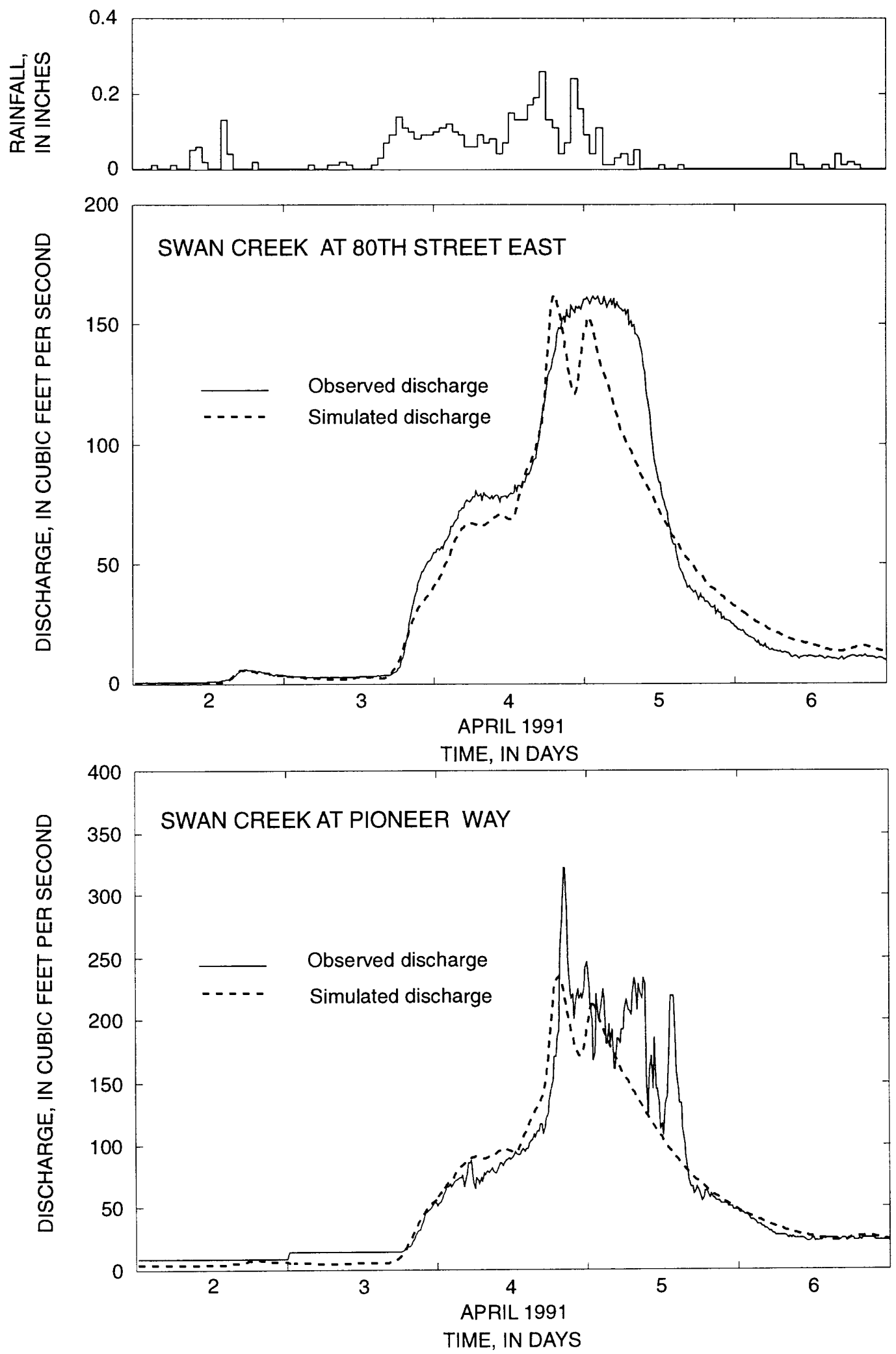

Figure 29.--Observed and simulated discharge at Swan Creek at 80th Street East and Swan Creek at Pioneer Way and rainfall recorded at the Canyon Road gage for the April 2-6, storm, Pierce County, Washington. 

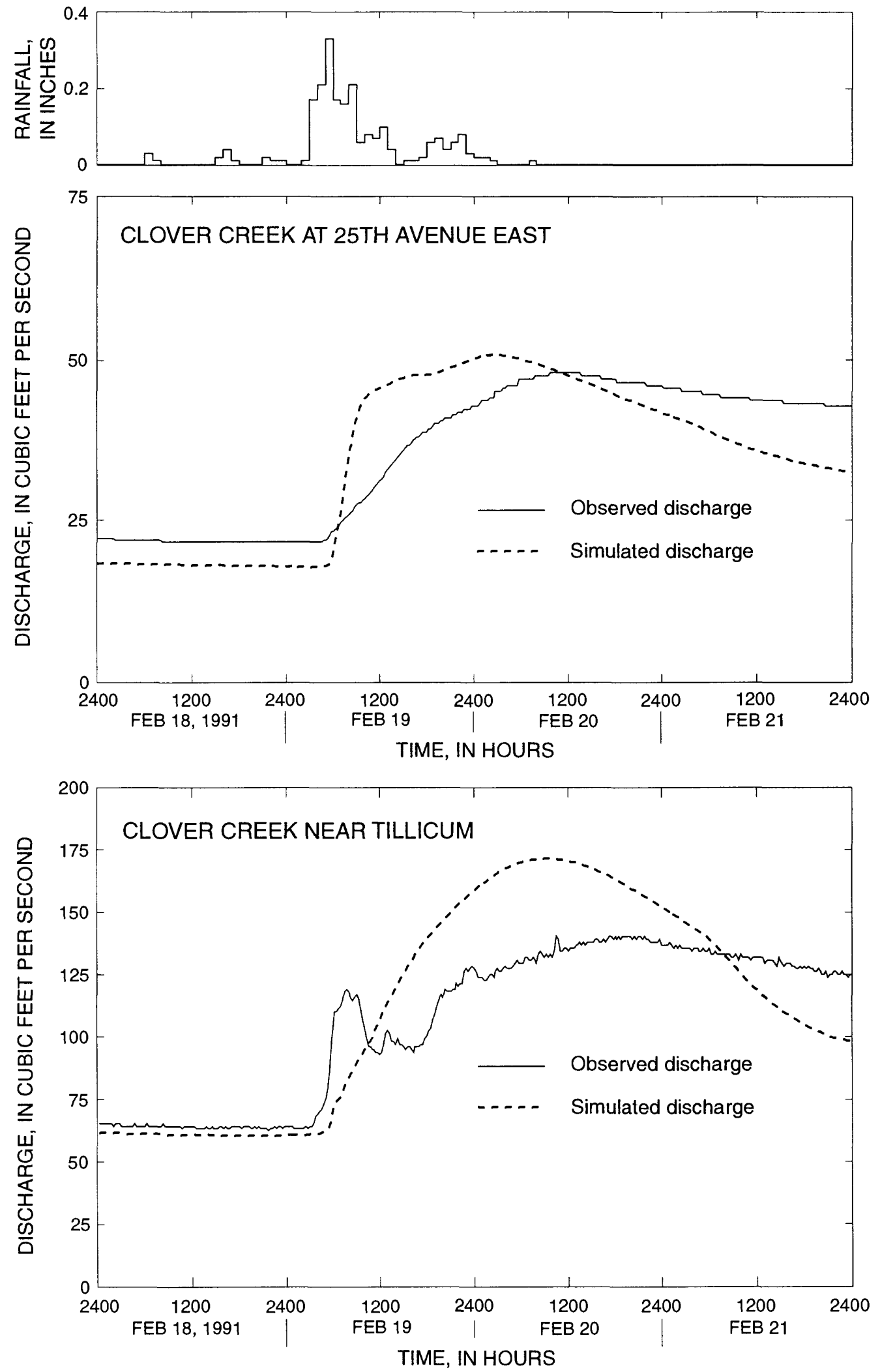

Figure 30.--Observed and simulated discharge at Clover Creek at 25th Avenue East and Clover Creek near Tillicum and rainfall recorded at the Canyon Road gage for the February 18-21, 1991, storm, Pierce County, Washington. 

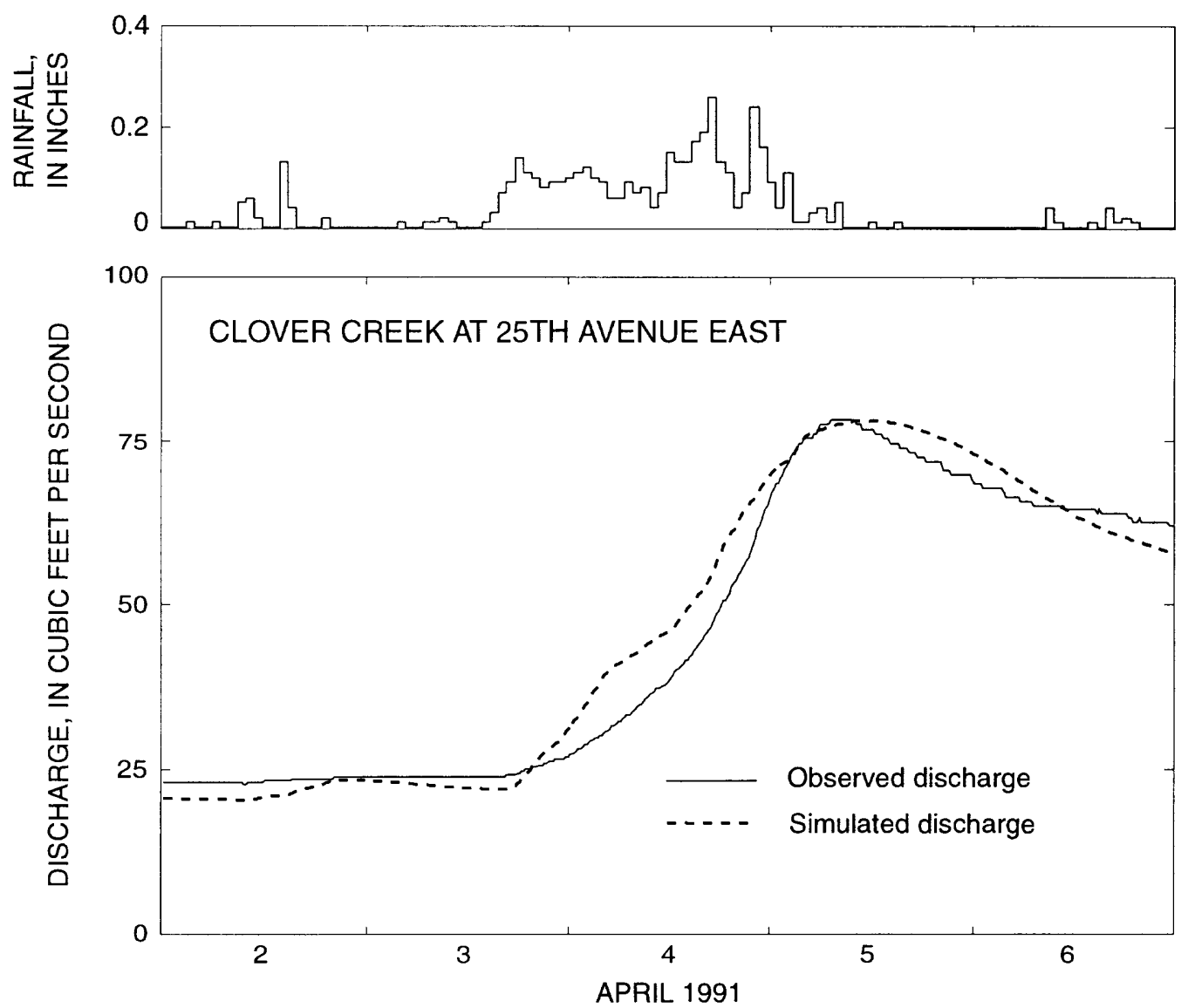

TIME, IN DAYS

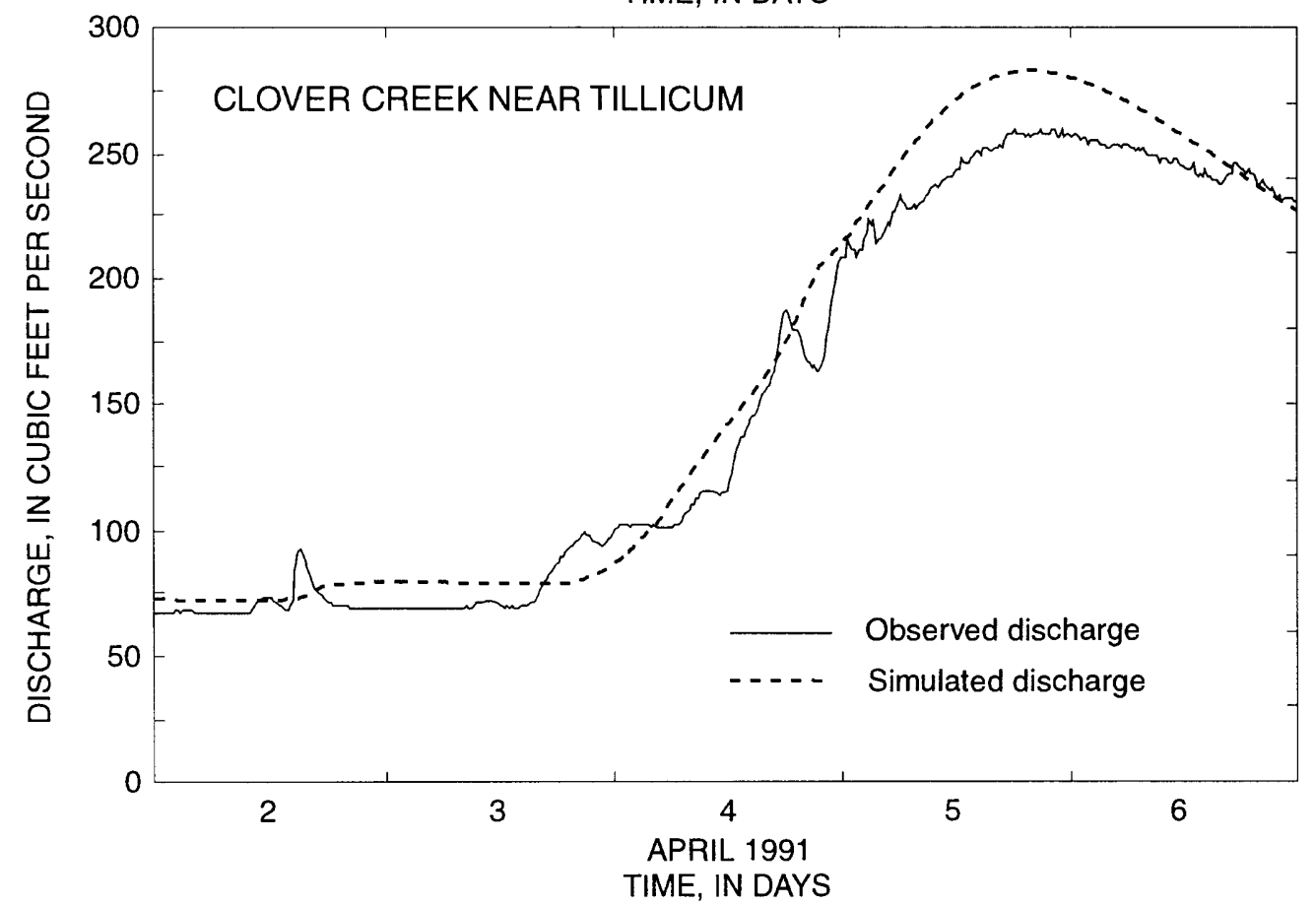

Figure 31.--Observed and simulated discharge at Clover Creek at 25th Avenue East and Clover Creek near Tillicum and rainfall recorded at the Canyon Road gage for the April 2-6, storm, Pierce County, Washington. 


\section{Daily Mean Discharges}

The accuracy of simulated daily mean discharges varied depending on the type of runoff response for the basin. At stations that have flashy responses to rainfall and go dry in the summer, the errors were large. Conversely, at stations with a small range of discharge, the errors were small. Also, as discharge values approached zero, large percentage errors were common, although the absolute error was small.

The mean error, bias, and standard error of estimate of simulated mean daily discharges were computed for the 10 continuous-recording stream-gaging sites (table 11). The table includes these error statistics for the total days during the calibration and validation periods when streamflow was observed as well as for three classes of flowlow, medium, and high. The mean absolute error is the average of the absolute values of the differences between simulated and observed runoff. Bias is the average of the differences accounting for the sign of the difference, either positive or negative, and indicates whether the model is oversimulating or undersimulating discharge. The standard error of estimate (SEE) is the standard deviation of the differences after accounting for the bias. If the differences are normally distributed and little or no bias is present, then two-thirds of all the differences will be less than or equal to the SEE. Approximately equal numbers of daily value comparisons are represented in the three classes of ranges of flow regime shown in table 11. When the value of the observed daily discharge was zero, no comparison was made. For the total number of daily value comparisons during the calibration simulations, the mean absolute error ranged from 5.8 to 115.6 percent, bias ranged from -30.0 to 74.0 percent, and the SEE ranged from 9.2 to 334.4 percent. For the validation period, mean absolute error ranged from 8.6 to 197.7 percent, bias ranged from -31.2 to 112.3 percent, and the SEE ranged from 10.7 to 906.8 percent. The largest daily mean flow errors were at the stream gage sites that became dry during the year (stations 12090340, 12090365, 12090380 , 12090400 , and 12102190). At the other sites, the validation errors for mean absolute error ranged from 8.6 to 68.6 percent, bias ranged from -7.6 to 50.5 percent, and the SEE ranged from 10.7 to 170.1 percent.

The accuracy of the simulated daily discharge in the high flow regime was generally simulated most accurately. The most accurate simulations of daily high-flow discharge were made at Clover Creek at 25th Avenue East (station 12090355), where the rise and fall of discharges during a storm were gradual and the total range of observed discharge ranged from 2.3 to 79 cubic feet per second and the percent SEE for high flows was 11.6 percent for the 1991 water year and 15.4 percent for the 1992 water year.

The models for the Suburban Catchment (station 12090340) and the Mixed-Use Catchment (station 12090380) simulated daily high flows least accurately, resulting in percent SEE of 57.2 and 43.5 percent, respectively for water year 1991 and 58.3 and 85.3 percent, respectively for water year 1992 . These two catchments were highly responsive basins, which produced flashy hydrographs that were difficult to simulate accurately. The quantity of runoff from these catchments was small, and any discharge above 0.04 cubic foot per second for the Suburban Catchment or 0.16 cubic foot per second for the Mixed-Use Catchment during the 1992 water year was in high-flow range. Mean absolute error for the high flow regime averaged 0.053 cubic foot per second (1991 water year) and 0.028 cubic foot per second (1992 water year) for the Suburban Catchment and 0.292 cubic foot per second (1991 water year) and 0.227 cubic foot per second (1992 water year) for the Mixed-Use Catchment.

Daily low flows were simulated less accurately than medium or high flows, except at the three stations located at the mouths of Diru, Clear, and Swan Creeks (stations 12102025,12102140 , and 12102212). At these three stations, the ground-water discharge maintained low flows at a relatively constant rate. The simple ground-water reservoir scheme used to simulate regional ground-water storage and discharge for these basins proved to be adequate for simulating low flows once it was calibrated to 1 year of streamflow data. At these sites the percent SEE ranged from 4.3 to 24.6 percent for the 2 years of simulation and represented some of the lowest errors for the simulation of daily discharges. By contrast, the largest percent errors for SEE at all of the other stations were found for the low flow regime. At stations where the stream often becomes dry, the percent SEE values were high, although the average mean absolute error and average SEE were small. The low flows for the North Fork of Clover Creek (station 12090400) showed the highest percent SEE at 1,542.9 percent for the 1992 water year, but within a range from 0.00 to 1.60 cubic feet per second (the range of discharge that defines the low-flow regime), the average mean absolute error was only 1.00 cubic foot per second, and the average SEE was only 1.68 cubic feet per second. 
Table 11.--Mean error, bias, and standard error of estimate of simulated mean daily discharges at the continuous-recording stream-gaging stations, Pierce County, Washington

[ $\mathrm{ft}^{3} / \mathrm{s}$, cubic feet per second; <, less than; >, greater than]

\begin{tabular}{|c|c|c|c|c|c|c|c|c|}
\hline \multirow{2}{*}{$\begin{array}{l}\text { Station } \\
\text { number }\end{array}$} & \multirow{2}{*}{\multicolumn{2}{|c|}{$\begin{array}{l}\text { Discharge } \\
\text { range } \\
\left(\mathrm{ft}^{3} / \mathrm{s}\right)^{1}\end{array}$}} & \multicolumn{2}{|c|}{$\begin{array}{l}\text { Mean } \\
\text { absolute } \\
\text { error }^{2}\end{array}$} & \multicolumn{2}{|c|}{ Bias $^{3}$} & \multicolumn{2}{|c|}{$\begin{array}{l}\text { Standard error } \\
\text { of estimate }\end{array}$} \\
\hline & & & Average & Percent & Average & Percent & Average & Percent \\
\hline \multicolumn{9}{|c|}{ Water Year 1991} \\
\hline \multirow[t]{4}{*}{12090340} & Low & $(<0.03)$ & 0.020 & 116.7 & 0.003 & 18.4 & 0.030 & 171.0 \\
\hline & Medium & $(0.03-0.05)$ & 0.024 & 75.9 & -0.011 & -33.3 & 0.026 & 86.1 \\
\hline & High & $(>0.05)$ & 0.053 & 43.4 & -0.029 & -15.2 & 0.069 & 57.2 \\
\hline & Total & & 0.032 & 78.9 & -0.012 & -11.3 & 0.047 & 114.7 \\
\hline \multicolumn{9}{|c|}{ Water Year 1992} \\
\hline \multirow[t]{4}{*}{12090340} & Low & $(<0.02)$ & 0.009 & 90.9 & -0.006 & -60.6 & 0.010 & 91.3 \\
\hline & Medium & $(0.02-0.04)$ & 0.015 & 64.9 & -0.008 & -36.9 & 0.016 & 70.4 \\
\hline & High & $(>0.04)$ & 0.028 & 45.1 & 0.003 & -5.2 & 0.037 & 58.3 \\
\hline & Total & & 0.018 & 63.6 & -0.004 & -31.2 & 0.025 & 73.6 \\
\hline \multicolumn{9}{|c|}{ Water Year 1991} \\
\hline \multirow[t]{4}{*}{12090355} & Low & $(<12.90)$ & 1.54 & 20.5 & -0.265 & -4.5 & 2.21 & 27.9 \\
\hline & Medium & $(12.90-23.70)$ & 2.60 & 15.0 & -1.618 & -9.7 & 2.37 & 13.8 \\
\hline & High & $(>23.70)$ & 4.68 & 13.6 & -3.863 & -11.0 & 4.07 & 11.6 \\
\hline & Total & & 2.94 & 16.4 & -1.913 & -8.4 & 3.33 & 19.2 \\
\hline \multicolumn{9}{|c|}{ Water Year 1992} \\
\hline \multirow[t]{4}{*}{12090355} & Low & $(<5.10)$ & 0.66 & 18.9 & 0.602 & 17.8 & 0.62 & 17.1 \\
\hline & Medium & $(5.10-9.60)$ & 2.66 & 38.7 & 2.341 & 34.4 & 3.03 & 47.8 \\
\hline & High & $(>9.60)$ & 1.88 & 10.8 & -0.260 & -1.4 & 2.83 & 15.4 \\
\hline & Total & & 1.73 & 22.8 & 0.894 & 16.9 & 2.64 & 33.8 \\
\hline \multicolumn{9}{|c|}{ Water Year 1991} \\
\hline \multirow[t]{4}{*}{12090365} & Low & $(<0.14)$ & 0.049 & 123.2 & -0.038 & -27.9 & 0.010 & 231.7 \\
\hline & Medium & $(0.14-0.28)$ & 0.090 & 47.7 & -0.050 & -29.9 & 0.090 & 44.6 \\
\hline & High & $(>0.28)$ & 0.238 & 24.2 & 0.035 & 4.2 & 0.433 & 29.7 \\
\hline & Total & & 0.126 & 64.9 & -0.017 & -17.8 & 0.258 & 136.6 \\
\hline \multicolumn{9}{|c|}{ Water Year 1992} \\
\hline \multirow[t]{4}{*}{12090365} & Low & $(<0.08)$ & 0.051 & 105.3 & 0.008 & -3.9 & 0.093 & 153.0 \\
\hline & Medium & $(0.08-0.17)$ & 0.074 & 69.3 & -0.009 & -7.2 & 0.100 & 90.0 \\
\hline & High & $(>0.17)$ & 0.130 & 36.6 & 0.011 & -8.6 & 0.175 & 46.4 \\
\hline & Total & & 0.087 & 69.2 & 0.004 & -6.6 & 0.129 & 103.3 \\
\hline
\end{tabular}


Table 11.--Mean error, bias, and standard error of estimate of simulated mean daily discharges at the continuous-recording stream-gaging stations, Pierce County, Washington--Continued

\begin{tabular}{|c|c|c|c|c|c|c|c|c|}
\hline \multirow{2}{*}{$\begin{array}{l}\text { Station } \\
\text { number }\end{array}$} & \multirow{2}{*}{\multicolumn{2}{|c|}{$\begin{array}{l}\text { Discharge } \\
\text { range } \\
\left(\mathrm{ft}^{3} / \mathrm{s}\right)^{1}\end{array}$}} & \multicolumn{2}{|c|}{$\begin{array}{l}\text { Mean } \\
\text { absolute } \\
\text { error }^{2}\end{array}$} & \multicolumn{2}{|c|}{$\operatorname{Bias}^{3}$} & \multicolumn{2}{|c|}{$\begin{array}{l}\text { Standard error } \\
\text { of estimate }\end{array}$} \\
\hline & & & Average & Percent & Average & Percent & Average & Percent \\
\hline \multicolumn{9}{|c|}{ Water Year 1991} \\
\hline \multirow[t]{4}{*}{12090380} & Low & $(<0.08)$ & 0.036 & 107.2 & -0.017 & -43.0 & 0.046 & 124.1 \\
\hline & Medium & $(0.08-0.39)$ & 0.125 & 66.4 & -0.089 & -45.8 & 0.116 & 58.0 \\
\hline & High & $(>0.39)$ & 0.292 & 33.8 & 0.019 & -1.5 & 0.438 & 43.5 \\
\hline & Total & & 0.152 & 69.1 & -0.028 & -30.0 & 0.266 & 85.0 \\
\hline \multicolumn{9}{|c|}{$\underline{\text { Water Year } 1992}$} \\
\hline \multirow[t]{4}{*}{12090380} & Low & $(<0.04)$ & 0.044 & 238.8 & 0.018 & 93.5 & 0.088 & 446.2 \\
\hline & Medium & $(0.04-0.16)$ & 0.098 & 115.5 & -0.020 & 37.2 & 0.148 & 193.0 \\
\hline & High & $(>0.16)$ & 0.227 & 66.7 & 0.104 & 20.7 & 0.327 & 85.3 \\
\hline & Total & & 0.121 & 141.5 & 0.046 & 50.9 & 0.212 & 286.4 \\
\hline \multicolumn{9}{|c|}{ Water Year 1991} \\
\hline \multirow[t]{4}{*}{12090400} & Low & $(<5.30)$ & 2.08 & 287.7 & 1.585 & 261.1 & 1.87 & 420.7 \\
\hline & Medium & $(5.30-16.70)$ & 3.98 & 40.0 & -3.019 & -29.7 & 3.49 & 34.5 \\
\hline & High & $(>16.70)$ & 7.71 & 21.5 & -1.420 & -7.0 & 10.37 & 25.6 \\
\hline & Total & & 4.60 & 115.6 & -0.963 & 74.0 & 6.64 & 274.6 \\
\hline \multicolumn{9}{|c|}{ Water Year 1992} \\
\hline \multirow[t]{4}{*}{12090400} & Low & $(<1.60)$ & 1.00 & 499.9 & 0.307 & 388.4 & 1.68 & 1542.9 \\
\hline & Medium & $(1.60-6.20)$ & 1.59 & 51.3 & -1.178 & -37.7 & 1.49 & 47.0 \\
\hline & High & $(>6.20)$ & 5.57 & 39.7 & -1.240 & -15.6 & 7.05 & 46.3 \\
\hline & Total & & 2.70 & 197.7 & -0.701 & 112.3 & 4.27 & 906.8 \\
\hline \multicolumn{9}{|c|}{ Water Year 1991} \\
\hline \multirow[t]{4}{*}{12090500} & Low & $(<18.0)$ & 1.68 & 18.6 & -1.16 & -14.5 & 1.72 & 17.6 \\
\hline & Medium & $(18.0-70.0)$ & 7.66 & 19.5 & 5.66 & 14.6 & 6.68 & 17.4 \\
\hline & High & $(>70.0)$ & 15.28 & 14.4 & -9.48 & -8.6 & 17.94 & 16.6 \\
\hline & Total & & 8.23 & 17.5 & -1.66 & -2.8 & 12.68 & 21.3 \\
\hline \multicolumn{9}{|c|}{ Water Year 1992} \\
\hline \multirow[t]{4}{*}{12090500} & Low & $(<5.68)$ & 1.77 & 165.6 & 1.744 & 164.9 & 1.76 & 257.5 \\
\hline & Medium & $(5.68-23.50)$ & 3.30 & 24.6 & -0.968 & -4.1 & 4.52 & 34.4 \\
\hline & High & $(>23.50)$ & 6.86 & 15.7 & -4.092 & -9.4 & 8.20 & 16.9 \\
\hline & Total & & 3.98 & 68.6 & -1.105 & 50.5 & 5.97 & 170.1 \\
\hline
\end{tabular}


Table 11.--Mean error, bias, and standard error of estimate of simulated mean daily discharges at the continuous-recording stream-gaging stations, Pierce County, Washington--Continued

\begin{tabular}{|c|c|c|c|c|c|c|c|c|}
\hline \multirow{2}{*}{$\begin{array}{l}\text { Station } \\
\text { number }\end{array}$} & \multirow{2}{*}{\multicolumn{2}{|c|}{$\begin{array}{l}\text { Discharge } \\
\text { range } \\
\left(\mathrm{ft}^{3} / \mathrm{s}\right)^{1}\end{array}$}} & \multicolumn{2}{|c|}{$\begin{array}{l}\text { Mean } \\
\text { absolute } \\
\text { error }^{2}\end{array}$} & \multicolumn{2}{|c|}{$\mathrm{Bias}^{3}$} & \multicolumn{2}{|c|}{$\begin{array}{l}\text { Standard error } \\
\text { of estimate }\end{array}$} \\
\hline & & & Average & Percent & Average & Percent & Average & Percent \\
\hline \multicolumn{9}{|c|}{ Water Year 1990} \\
\hline \multirow[t]{4}{*}{12102025} & Low & $(<1.13)$ & 0.179 & 19.9 & 0.094 & 12.3 & 0.223 & 24.6 \\
\hline & Medium & $(1.13-1.37)$ & 0.216 & 17.1 & -0.064 & -4.9 & 0.302 & 24.0 \\
\hline & High & $(>1.37)$ & 0.485 & 20.5 & -0.014 & 1.4 & 0.863 & 28.4 \\
\hline & Total & & 0.290 & 19.2 & 0.009 & 3.3 & 0.539 & 26.6 \\
\hline \multicolumn{9}{|c|}{ Water Year 1991} \\
\hline \multirow[t]{4}{*}{12102025} & Low & $(<1.13)$ & 0.102 & 13.1 & 0.045 & 5.9 & 0.132 & 17.8 \\
\hline & Medium & $(1.13-1.57)$ & 0.206 & 15.2 & -0.110 & -7.6 & 0.259 & 19.5 \\
\hline & High & $(>1.57)$ & 0.692 & 26.9 & -0.151 & -6.0 & 1.036 & 34.0 \\
\hline & Total & & 0.334 & 18.4 & 0.072 & -2.6 & 0.625 & 25.4 \\
\hline \multicolumn{9}{|c|}{ Water Year 1990} \\
\hline \multirow[t]{4}{*}{12102140} & Low & $(<8.77)$ & 0.317 & 3.7 & -0.049 & -0.5 & 0.366 & 4.3 \\
\hline & Medium & $(8.77-9.11)$ & 0.313 & 3.5 & -0.010 & -0.1 & 0.452 & 5.0 \\
\hline & High & $(>9.11)$ & 1.404 & 10.2 & 0.471 & 2.6 & 2.462 & 14.3 \\
\hline & Total & & 0.679 & 5.8 & 0.138 & 0.7 & 1.474 & 9.2 \\
\hline \multicolumn{9}{|c|}{ Water Year 1991} \\
\hline \multirow[t]{4}{*}{12102140} & Low & $(<9.32)$ & 0.380 & 4.4 & 0.009 & 0.3 & 0.487 & 5.6 \\
\hline & Medium & $(9.32-10.25)$ & 0.631 & 6.5 & -0.603 & -6.2 & 0.491 & 5.1 \\
\hline & High & $(>10.25)$ & 2.149 & 14.9 & -0.398 & -6.1 & 2.948 & 16.2 \\
\hline & Total & & 1.054 & 8.6 & -0.330 & -4.0 & 1.760 & 10.7 \\
\hline \multicolumn{9}{|c|}{ Water Year 1990} \\
\hline \multirow[t]{4}{*}{12102190} & Low & $(<0.75)$ & 0.514 & 234.5 & 0.107 & 109.9 & 0.814 & 569.4 \\
\hline & Medium & $(0.75-3.20)$ & 1.062 & 66.1 & -0.145 & -15.1 & 1.470 & 85.5 \\
\hline & High & $(>3.20)$ & 2.736 & 27.1 & 0.082 & 6.8 & 3.866 & 33.7 \\
\hline & Total & & 1.436 & 109.1 & 0.014 & 33.6 & 2.414 & 334.4 \\
\hline \multicolumn{9}{|c|}{ Water Year 1991} \\
\hline \multirow[t]{4}{*}{12102190} & Low & $(<0.85)$ & 0.286 & 132.6 & -0.096 & 0.0 & 0.349 & 205.8 \\
\hline & Medium & $(0.85-3.58)$ & 0.894 & 47.4 & -0.658 & -34.4 & 0.777 & 41.3 \\
\hline & High & $(>3.58)$ & 3.339 & 22.0 & -2.090 & -7.9 & 5.580 & 27.0 \\
\hline & Total & & 1.502 & 67.6 & -0.945 & -14.1 & 3.337 & 122.6 \\
\hline
\end{tabular}


Table 11.--Mean error, bias, and standard error of estimate of simulated mean daily discharges at the continuous-recording stream-gaging stations, Pierce County, Washington--Continued

\begin{tabular}{|c|c|c|c|c|c|c|c|c|}
\hline \multirow{2}{*}{$\begin{array}{l}\text { Station } \\
\text { number }\end{array}$} & \multirow{2}{*}{\multicolumn{2}{|c|}{$\begin{array}{l}\text { Discharge } \\
\text { range } \\
\left(\mathrm{ft}^{3} / \mathrm{s}\right)^{1}\end{array}$}} & \multicolumn{2}{|c|}{$\begin{array}{l}\text { Mean } \\
\text { absolute } \\
\text { error }^{2}\end{array}$} & \multicolumn{2}{|c|}{$\operatorname{Bias}^{3}$} & \multicolumn{2}{|c|}{$\begin{array}{l}\text { Standard error } \\
\text { of estimate }\end{array}$} \\
\hline & & & Average & Percent & Average & Percent & Average & Percent \\
\hline \multicolumn{9}{|c|}{ Water Year 1990} \\
\hline \multirow[t]{4}{*}{12102212} & Low & $(<2.45)$ & 0.340 & 15.9 & 0.084 & 4.7 & 0.404 & 18.2 \\
\hline & Medium & $(2.45-4.08)$ & 0.505 & 16.0 & -0.221 & -6.7 & 0.773 & 24.5 \\
\hline & High & $(>4.08)$ & 3.712 & 28.9 & 0.156 & -3.6 & 5.459 & 35.4 \\
\hline & Total & & 1.503 & 20.2 & 0.007 & -1.8 & 3.157 & 27.2 \\
\hline \multicolumn{9}{|c|}{ Water Year 1991} \\
\hline \multirow[t]{4}{*}{12102212} & Low & $(<2.79)$ & 0.362 & 16.1 & 0.003 & 0.4 & 0.406 & 18.1 \\
\hline & Medium & $2.79-5.10)$ & 0.449 & 12.1 & -0.242 & -5.8 & 0.555 & 14.8 \\
\hline & High & $(>5.10)$ & 3.914 & 24.4 & -2.803 & -17.5 & 5.003 & 23.6 \\
\hline & Total & & 1.569 & 17.5 & -1.009 & -7.6 & 3.180 & 20.5 \\
\hline
\end{tabular}

${ }^{1}$ Low, medium, and high-flow average ranges are the three ranges of observed non-zero daily mean discharges with approximately equal number of daily discharge values in each range for the period of record at the station. The term "total" refers to the complete record of non-zero daily mean discharges at the station.

${ }^{2} \mathrm{~S}$, simulated daily mean discharge, in cubic feet per second; $\mathrm{O}$, observed daily mean discharge, in cubic feet per second; N, number of daily values in the sample; 11 , absolute value; Mean absolute error, average = SUM(IS-OI/N); and Mean absolute error, percent $=100 \times(\mathrm{SUM}(\mathrm{IS}-\mathrm{O} / / \mathrm{O})) / \mathrm{N}\}$, for all $\mathrm{O}>0.0$.

${ }^{3}$ Bias, average $=\operatorname{SUM}[(\mathrm{S}-\mathrm{O}) / \mathrm{N}] ;$ Bias, percent $=100 \times \operatorname{SUM}\{[(\mathrm{S}-\mathrm{O}) / \mathrm{O}] / \mathrm{N}\}$, for all $\mathrm{O}>0.0$.

${ }^{4} \mathrm{RMSE}$, average $=\mathrm{SQRT}\left\{\mathrm{SUM}\left[(\mathrm{S}-\mathrm{O})^{2} / \mathrm{N}\right]\right\} ; \mathrm{RMSE}$, percent $=100 \mathrm{XSQRT}\left\{\mathrm{SUM}[(\mathrm{S}-\mathrm{O}) / \mathrm{O})^{2} / \mathrm{N}\right]$, for all $\mathrm{O}>0.0$; Standard error of estimate, average $=[\mathrm{N} /(\mathrm{N}-1)] \times \mathrm{SQRT}\left[(\mathrm{RMSE}, \text { average })^{2}-(\text { Bias, average })^{2}\right]$; Standard error of estimate, percent $=[\mathrm{N} /(\mathrm{N}-1)]$ X SQRT $\left[(\text { RMSE,percent })^{2}-(\text { Bias,average })^{2}\right]$.

\section{Sources of Errors}

The primary sources of error that can explain the differences between observed and simulated streamflows were: (1) errors in the two time-series inputs to the model-precipitation and PET, (2) errors in the measurement and calculation of true discharge, and (3) errors in the representation of the hydrologic processes by the conceptual model and by the HSPF model.

Comparison of the precipitation data showed that the rainfall varied throughout the study area as much as 18.7 percent annually. Additional rain gages would have reduced the error of the areal variability, but the gage network density used in this study, approximately one gage per 14.5 square miles, provided a practical number of gages that could adequately represent the existing precipitation patterns (or lack of patterns) and allow reasonably good estimates of the areal distribution of precipitation. The 15-minute recording time step of the precipitation gages equalled the time step used by the simulation model and provided reasonably accurate estimates of rainfall intensities that are relatively low in western Washington. Measurements of precipitation are subject to various sources of error. Two of the major sources of errors that reduce the catch efficiency of a rain gage are high winds and high-intensity rainfall. These errors were minimized in this study because all the gages were located in clearings surrounded by windbreaks and no high rainfall intensities were measured. (Generally, large errors for 
tipping-bucket rain gages begin at intensities above 5 inches per hour.) The manufacturers of the tippingbucket gages used in this study specify an accuracy of measurement within 4 percent of the true value when rain falls at a rate of 2.2 inches per hour.

Although pan-evaporation data are subject to a variety of sources of error when PET from land is estimated, pan evaporation is the most widely used measure of PET, and the ratio of annual lake evaporation to pan evaporation (pan coefficient) is generally consistent over time (Linsley, Kohler, and Paulhus, 1982, p.146). This study was fortunate to have one of the few National Weather Service pan stations in western Washington located only a few miles from the study area. During the winter months when pan data were not collected, daily PET was estimated. During these months, PET is small compared with the quantity of precipitation; therefore any errors associated with the estimates of daily PET will also be small. The relatively small quantity of PET compared to precipitation during the winter is shown by the following totals: during the months of November through March for the period of data collection, 80.50 inches of rainfall was measured at the Canyon Road site, and for the same period only 10.02 inches of PET was estimated.

Another source of error was the inaccuracy of the measured or observed discharges to which the models were calibrated. In the previous tables and hydrographs, the differences between observed and simulated discharge include this observational error as well as simulation error. With the exception of the Suburban Catchment (station 12090340), all of the continuous-recording discharge records were subjectively rated as fair or good. A fair rating meant that 95 percent of the observed daily discharge values were accurate within 15 percent of true discharge; a good rating was within 10 percent. The Suburban Catchment had variable backwater conditions at times affecting the stage-discharge relationship, and the records were rated poor (less than fair accuracy). Also, the discharge records at several stations sometimes had to be estimated because of gage malfunctions or problems associated with damage sustained during floods, and in these cases the estimated streamflow record's accuracy was downgraded to fair or poor.

The final source of error was the inability of the model to represent the actual hydrologic processes in the watershed. As mentioned previously, although many complex physical processes affect the timing and quantity of runoff, the conceptual model provided general guidelines to simplify the complex runoff processes by considering only the most important ones that affect runoff. In turn, the simulation model made further simplifications of the conceptual model into a one-dimensional abstraction of the natural system to allow numerical solutions of the runoff processes from the limited amount of information known about the physical characteristics of the watershed. Model error can be expected to increase with each simplification of the natural system.

A goal of this study was to minimize model errors within a modeling framework that preserves the important hydrologic aspects as outlined by the conceptual model and uses data that can be obtained using practical means. The HSPF model proved to have the flexibility and sufficiently complex process algorithms to allow simulation of runoff according to the conceptual model, and, for the most part, the data requirements that could be were met. It was realized during the calibration process of the basin models that several important data items in the simulation models could not be measured directly or precisely. These items included the correct quantity of channel-detention storage in the headwater basins and the Clover Creek floodplain, the quantities of channel losses and gains, the quantity of regional ground-water storage, and the regional ground-water flow paths. These data requirements had to be estimated indirectly from observed discharge data. Once these data requirements had been estimated from a minimum of 1 water year of streamflow measurements at strategic locations throughout the basin, model error was reduced substantially from the error obtained from the preliminary models.

In the Clover Creek Basin, the accuracy of the simulations was reduced because of the limited ability of the HSPF model to simulate complex regional ground-water flow processes. The simple ground-water reservoir scheme that was incorporated into the models was successful in maintaining the proper water balance of the regional ground-water system and distributing the water to the correct locations, but the Clover Creek Basin model did not always simulate the timing of the distribution of the ground water accurately. At stations where ground-water discharge accounts for a large percentage of the runoff during storms (Clover Creek at 25th Avenue East, station 12090355, and Clover Creek near Tillicum, station 12090500), the inaccuracies of the timing of ground-water discharge are evident in the storm hydrographs (fig. 30). The quantities of runoff volumes and the peak discharges may be closely simulated, but the shapes of the hydrographs and the timing of the peak discharges were not always correctly simulated. The ground-water reservoir simulation used in the basin models is not sufficiently sophisticated to determine the correct travel times or the dynamic changes in flow paths and discharge rates within the regional ground-water system. 


\section{Annual Distribution of Runoff by the Basin Models}

The annual distribution of simulated runoff from the 10 different land segments (table 12) and the simulated annual water balance for the two basin models and selected basins in the study area (table 13) show how land cover and other characteristics particular to individual basins affect the distribution of water in the study area. Distribution of runoff from the different land segments was computed from the precipitation record from the Canyon Road gage as the input of moisture onto the land segments. The effects of the 10 land segment types on the quantities of actual ET, runoff to the stream along various flow paths, and recharge to the regional aquifer can be compared directly for the 3 water years of data collection. The major components of the basin water balance are tabulated in inches to show how runoff, recharge, and ground-water discharge can vary from basin to basin. The West Fork Clarks and Canyon Creek Basin model results were not included in the water balance because there was inadequate streamflow information at the mouths of these basins to calibrate ground-water inputs into these streams, which are known to receive water from springs in the lower portions of the basin. The Clear-Clarks Basin model was calibrated only to available observed peak flow data for these two basins, and therefore, its simulation of low flows is not believed to be reliable.

The distribution of simulated runoff for the different land segments (table 12) shows how the first seven generalizations from the conceptual model about runoff from hillslopes (see section "Generalizations About Runoff in the Study Area") agree with the results from the numerical model on an annual basis. Actual ET was less on the impervious (EIA) and grass-cover or "disturbed" land segments (TGF, TGM, TGS, and OG) than on the "undisturbed" land segments (TFF, TFM, TFS, OF, and SA). Overland flow was the only type of runoff from EIA land segments, and it occurred more often on the disturbed areas than on the undisturbed land segments. Flat-till and saturated land segments generally produced more overland flow than the moderate- and steep-sloped land segments. Subsurface flow was the predominant flow process on the till land segments, and ground-water flow was the predominant flow process on the outwash land segments.
Consistent with the last generalization from the conceptual model (see section "Generalizations About Runoff in the Study Area"), the simulated regional ground-water system dramatically influenced annual runoff in the individual basins (table 13). For example, in the Clear Creek Basin more simulated water ran off the basin than was applied to the basin as precipitation, and over 80 percent of the simulated runoff was ground-water discharge from the ground-water reservoir (table 13). During the 1992 water year, the Clover Creek Basin model routed 47.9 percent of the water received from precipitation out of the basin through the regional ground-water flow path, and only 9.9 percent of the precipitation was routed out of the basin as streamflow runoff.

Channel losses can account for a large portion of the ground-water recharge (recharge to the regional groundwater reservoir in table 13) in certain basins. For example, in the Swan Creek Basin, where channel losses are small, the total simulated ground-water recharge in water year 1990 was 5.95 inches, whereas in the Diru Creek Basin, with a similar distribution of land-segment types and similar topography, total simulated ground- water discharge was 17.73 inches. The difference between the two totals is due to the difference in the quantity of simulated channel losses in the two basins. There were no clues during the initial observations in the field and from the soil and topographic maps that the channel losses in the two basins could be quite different. These channel- loss differences were discovered only after seepage runs on the two basins and calibration of the simulation models had been made. 


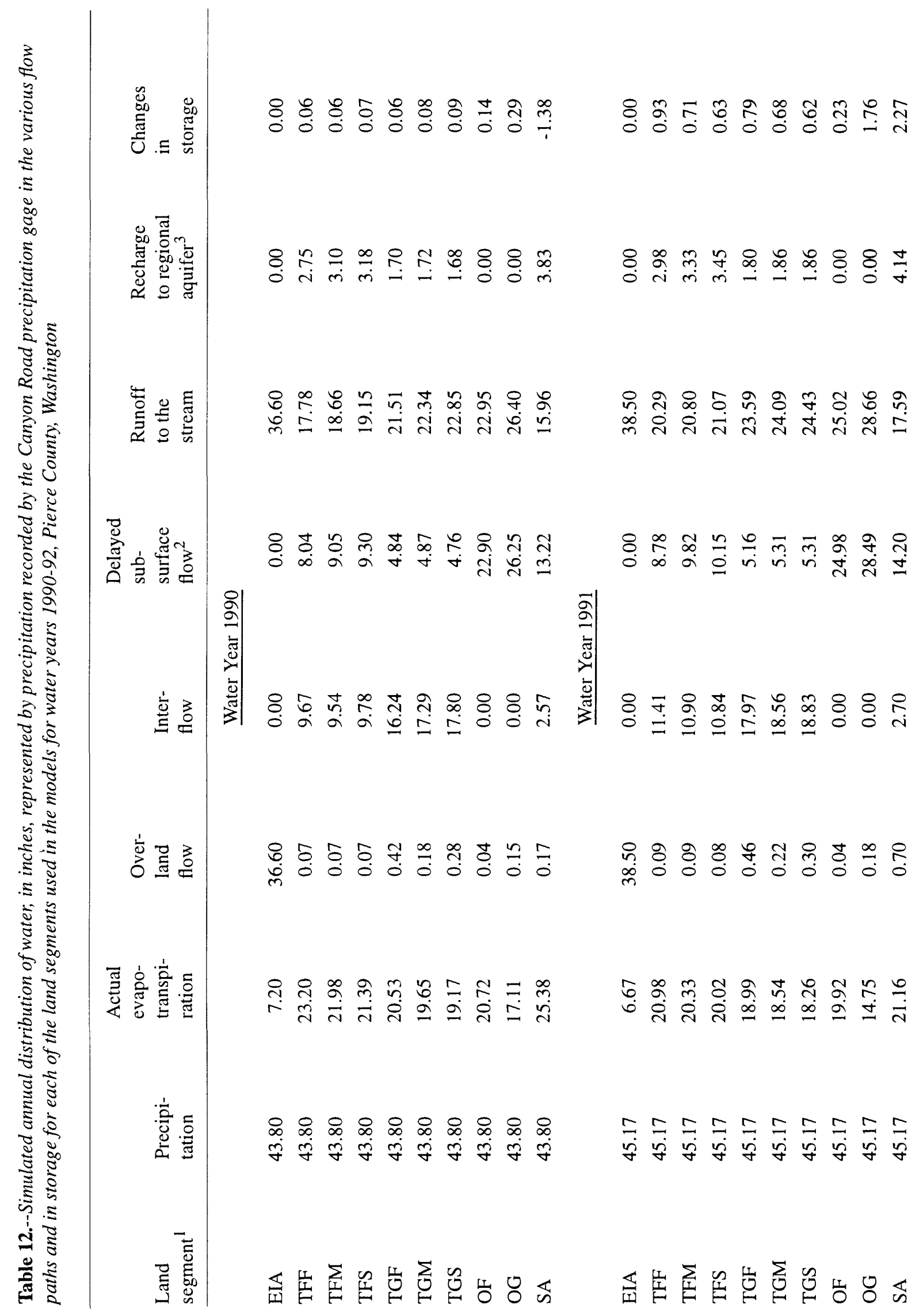




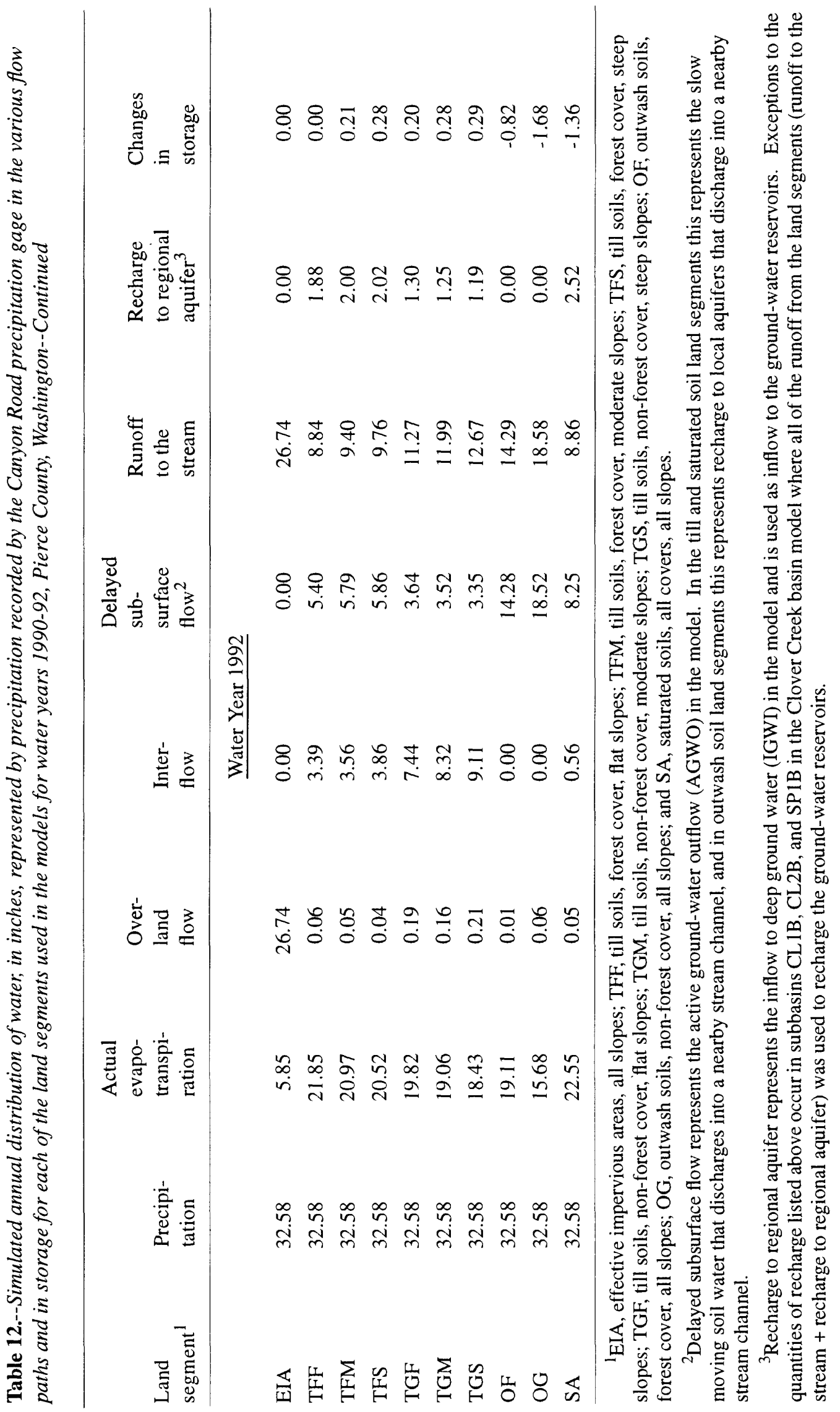




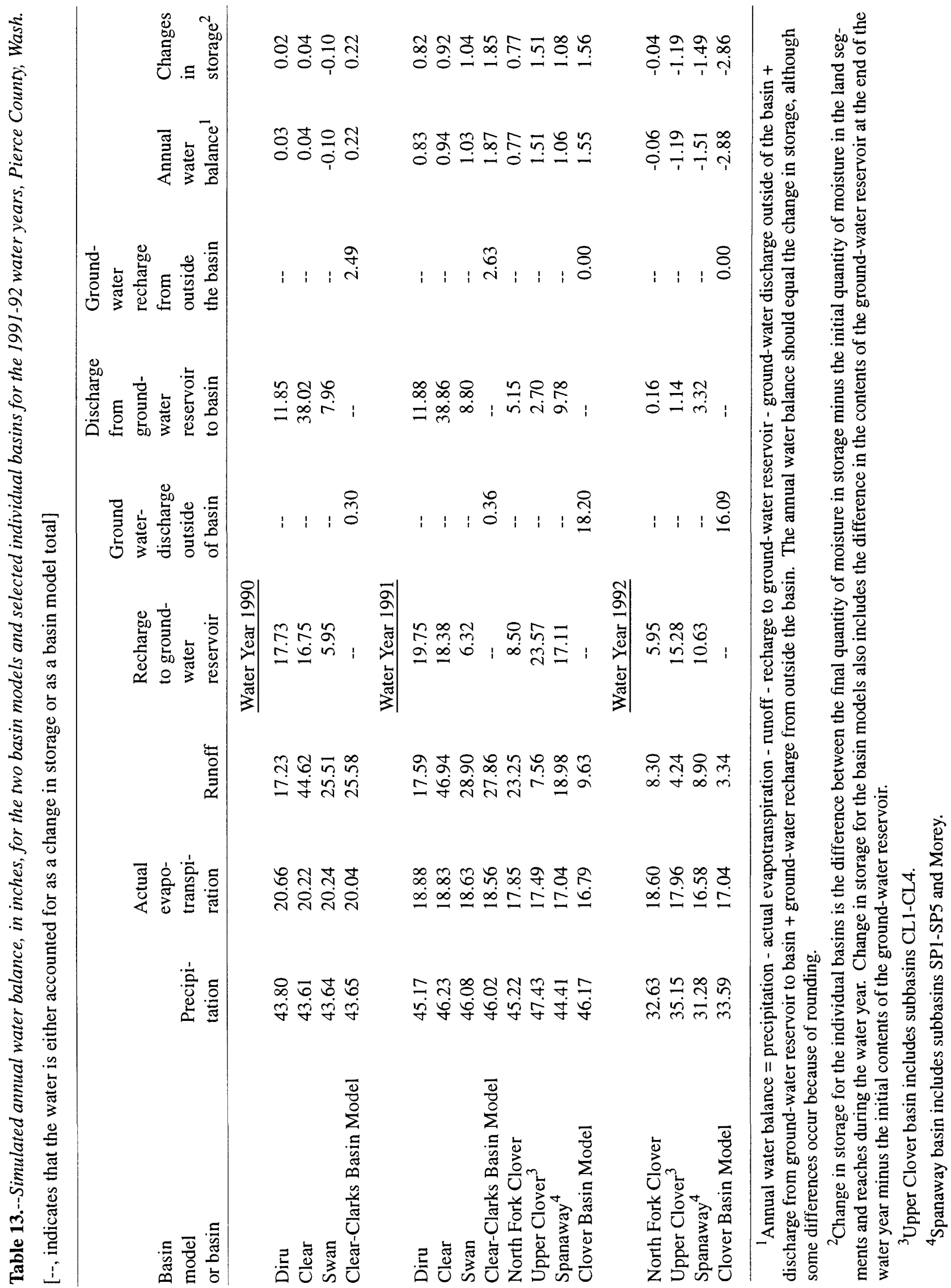




\section{Long-term Simulation}

Long-term simulations with the two basin models showed that the models were numerically stable and that extremes of hydrologic conditions during the long-term were well represented by the data collection period. Runoff and ground-water reservoir volumes were simulated for a 30-year period, water years 1962-91, for the ClearClarks Basin model and for a 31-year period, water years 1962-92, for the Clover Basin model. The models were considered stable if simulated storages of water in the models did not continue to grow or decrease over time and if realistic runoff rates or volumes continued to be simulated throughout the long-term simulations. How well the data-collection period represented long-term hydrologic conditions was assessed by comparing the minimum and maximum values of various outputs for both the long-term simulations and the 2-year simulations for the data collection period.

The long-term simulations were run at an hourly time step and used hourly precipitation recorded at McMillin Reservoir and daily pan data from the Puyallup 2 West Experimental Station or estimated PET when observed pan data were not available to provide the required inputs for driving the models. As shown previously, the precipitation record at McMillin Reservoir offers a good representation of the precipitation inputs to the study area, and therefore, the simulations are believed to be accurate within the range of discharges and errors experienced during the calibration and validation model runs for the current land uses in the basins. The estimated PET data were derived in a slightly different manner than previously estimated because long-term percent possible sunshine data were not available to estimate the solar radiation input to the Jensen-Haise equation. Instead, monthly equations based on regression equations of observed solar radiation and daily maximum and minimum mean air temperatures at the National Weather Service station at Seattle-Tacoma airport were developed to estimate solar radiation (H.H.

Bauer, U.S. Geological Survey, written commun., 1993). These regression equations and records of minimum and maximum air temperatures recorded at the National Weather Service Station at Puyallup 2 West Experimental Station were used to estimate solar radiation, and PET was estimated with the Jensen-Haise equation. There are no data to compare the simulated discharges with observed discharges prior to 1989 , and furthermore, the comparisons would not be valid because the land use of the study area has continually changed over the 30 - to 31 -year period, and the change has altered the runoff characteristics of the basins. Changing land uses in the basins were not accounted for in the long-term models.
Results from the long-term model runs show that the models are stable. The simulated volumes of water in the ground-water reservoir did not show any tendency to increase or decrease continuously over the years during the simulations. However, several FTABLE's had to be extended because the simulated volumes were beyond the maximum volumes defined for the 2-year model runs. Only one long-term well-level record was found for a well in the study area that could indicate the general trend of long-term changes in ground-water storage. The well, located in the headwaters of Canyon Creek and operated by Summit Water and Supply Company, has approximately the same static water level in 1991 as the original static water level (197.5 feet) in 1955, indicating no net long-term gains or losses in ground-water storage in this aquifer (Neal Doyle, oral commun.). Simulation of the ground-water reservoirs approximated this stability. For example, FTABLE 50, the ground-water reservoir for the Clear-Clarks Basin model, gained only 278 acre-feet by the end of the 1991 water year or only 7.0 percent of its initial contents during the long-term simulation. Another indication of the stability of the models is shown by the maximum and minimum volumes of the ground-water reservoirs (table 14) that were reached during the long- term simulation. The minimum and maximum volumes defined a range that did not extend much beyond the range of the 2-year simulations, nor did they ever reach a condition of zero volumes.

The extreme flooding potential of the study area was well represented by the January 9, 1990, flood. Simulated maximum discharge for the long-term model runs at all the continuous-recording stream-gaging stations in the two basin models-except for the station at Clover Creek near Tillicum (station No. 12090500)—occurred on January 9, 1990 (table 14). In the till-mantled basins (the Clover Creek stations represent mostly outwash basins), the flood peaks from this storm represent the largest flood peaks for the last 31 years, and since the Clear-Clarks Basin model was calibrated to this storm, users of the model can be confident of its ability to simulate the large floods that may be encountered in the study area within the margins of error defined by the simulations of the January 9, 1990, flood. Minimum flows were better represented by the long-term simulations than by the 2-year simulations; minimums during the long-term simulations reached lower values than during the 2-year simulations at all the sites except the two sites that simulated zero discharges during both simulations. 
Table 14.--Minimum and maximum simulated discharge for the continuous-recording streamflow sites and minimum and maximum simulated volumes for the ground-water reservoir for two periods of simulations for the Clear-Clarks and Clover Basin models, Pierce County, Washington

\begin{tabular}{|c|c|c|c|c|}
\hline \multirow[b]{3}{*}{ Streamflow site } & \multicolumn{4}{|c|}{ Discharge, in cubic feet per second } \\
\hline & \multicolumn{2}{|c|}{$\begin{array}{c}\text { Simulation period } \\
\text { (1-hour time step) } \\
\text { Water Years } 1962 \text { to } 1991\end{array}$} & \multicolumn{2}{|c|}{$\begin{array}{c}\text { Simulation period } \\
(15 \text {-minute time step }) \\
\text { Water Years } 1990 \text { and } 1991\end{array}$} \\
\hline & $\overline{\text { Minimum }}$ & $\overline{\text { Maximum }}$ & Minimum & Maximum \\
\hline Diru Creek below hatchery and Pioneer Way & 0.49 & 47.7 & 0.52 & 46.7 \\
\hline Clear Creek at Pioneer Way below hatchery & 2.45 & 176.1 & 7.92 & 185.1 \\
\hline Swan Creek at 80th Street East & 0.00 & 208.8 & 0.00 & 207.6 \\
\hline Swan Creek at Pioneer Way & 0.37 & 277.6 & 1.47 & 280.4 \\
\hline
\end{tabular}

Volume, in acre-feet

\begin{tabular}{|c|c|c|c|c|}
\hline \multirow[b]{3}{*}{ Ground-water reservoir--Clear-Clarks Basin } & \multirow{2}{*}{\multicolumn{2}{|c|}{$\begin{array}{c}\text { Simulation period } \\
\text { (1-hour time step) } \\
\text { Water Years } 1962 \text { to } 1991\end{array}$}} & \multirow{2}{*}{\multicolumn{2}{|c|}{$\begin{array}{c}\text { Simulation period } \\
(15-\text {-minute time step }) \\
\text { Water Years } 1990 \text { and } 1991\end{array}$}} \\
\hline & & & & \\
\hline & $\overline{\text { Minimum }}$ & $\overline{\text { Maximum }}$ & $\overline{\text { Minimum }}$ & Maximum \\
\hline Ground-water reservoir & 679.7 & $9,588.8$ & $3,370.0$ & $8,294.6$ \\
\hline
\end{tabular}

\begin{tabular}{|c|c|c|c|c|}
\hline \multirow[b]{3}{*}{ Streamflow site } & \multicolumn{4}{|c|}{ Discharge, in cubic feet per second } \\
\hline & \multicolumn{2}{|c|}{$\begin{array}{c}\text { Simulation period } \\
\text { (1-hour time step) } \\
\text { Water Years } 1962 \text { to } 1992\end{array}$} & \multicolumn{2}{|c|}{$\begin{array}{c}\text { Simulation period } \\
(15 \text {-minute time step) } \\
\text { Water Years } 1991 \text { and } 1992\end{array}$} \\
\hline & Minimum & Maximum & Minimum & Maximum \\
\hline Clover Creek at 25th Avenue East & 1.62 & 83.6 & 3.05 & 77.2 \\
\hline North Fork Clover Creek near Parkland & 0.00 & 530.4 & 0.00 & 402.1 \\
\hline Clover Creek near Tillicum & 0.63 & 295.5 & 2.13 & 283.0 \\
\hline
\end{tabular}

\begin{tabular}{|c|c|c|c|c|}
\hline \multirow[b]{3}{*}{ Ground-water reservoir--Clover Basin } & \multicolumn{4}{|c|}{ Volume, in acre-feet } \\
\hline & \multicolumn{2}{|c|}{$\begin{array}{c}\text { Simulation period } \\
\text { (1-hour time step) } \\
\text { Water Years } 1962 \text { to } 1992\end{array}$} & \multicolumn{2}{|c|}{$\begin{array}{c}\text { Simulation period } \\
(15 \text {-minute time step) } \\
\text { Water Years } 1991 \text { and } 1992\end{array}$} \\
\hline & Minimum & Maximum & Minimum & Maximum \\
\hline Upper ground-water reservoir & $1,105.4$ & $18,240.2$ & $2,676.0$ & $16,659.9$ \\
\hline Lower ground-water reservoir & $1,955.2$ & $16,584.9$ & $4,111.1$ & $13,869.2$ \\
\hline
\end{tabular}




\section{SUMMARY}

A study by the U.S. Geological Survey, in cooperation with the Pierce County Department of Public Works, described the hydrology of small stream basins in central Pierce County, Washington, by means of conceptual and simulation models that represent and simulate the influence of physical properties of a basin on the runoff processes and allow users to simulate runoff once changes to these properties are made. Recent urbanization of rural areas in Pierce County has increased runoff in the small streams of the area, which in turn has increased flooding, erosion, and sedimentation problems. The interactions of the climate and basin properties are complex and require a numerical simulation model to assess the cumulative effects that changes to the basin may have on streamflows. The HSPF numerical model was chosen to construct two basin models according to the general guidelines supplied by the conceptual model (for three basins in central Pierce County-Clear, Clarks, and Clover Creeks). A network of 28 streamflow gages and six precipitation gages was constructed and monitored in phases for 3 years to provide 2 water years of observed data in each of the basins to calibrate and validate basin simulation models.

The conceptual model characterizes the relations of predominant runoff processes to the different soil types and land covers in the study area and to several other important hydrologic considerations. The conceptual model states that rapid, direct overland flow occurs on impervious areas. Horton overland flow can be an important runoff process in disturbed areas, but it is not important in undisturbed areas. Saturation overland flow is important in depressions, stream bottoms, and flat tillcapped hilltops once the available water capacity of the soils has been met. Subsurface flow combined with return flow and saturation overland flow is the predominate flow process on glacial-till hillslopes. Storm-runoff-producing zones on these hillslopes expand and contract between seasons and during storms and can produce variable quantities of runoff from storms with similar precipitation totals. Ground-water flow is the predominant runoff process on glacial outwash deposits, and this situation results in slow and attenuated runoff responses to storms. Other considerations in the conceptual model that affect runoff include the following generalizations: (1) retention and plant transpiration is reduced when lands are disturbed; (2) wetlands, lakes, ponds, and over-bank storage in floodplains are important floodwater-storage areas that reduce flood peaks; (3) channel losses can be important for recharge to ground-water aquifers and the reduction of streamflows downstream; and (4) ground-water flow boundaries do not necessarily coincide with surface drainage boundaries.
Preliminary runoff simulation models were constructed following the general procedures used in a similar study by Dinicola (1990). Basins were subdivided into subbasins, and in all but three subbasins, channel reaches were defined. Subbasins were delineated according to the surface drainage boundaries, except in the southern part of Clover Creek where ground-water flow processes dominate and little or no surface drainage network exists. Subbasin boundaries in this area were defined by groundwater flow boundaries, which were determined from maps of the water table (Brown and Caldwell, 1985). Flow tables (FTABLE's) that define how simulated streamflows are routed through a stream reach were constructed for each reach from field and map surveys of a typical channel cross-section geometry and roughness and channel slope. Each subbasin was divided into land segments with similar runoff responses to precipitation. Nine types of pervious land segments differing by soil type, slope, or land cover and one type of impervious land segment were used to characterize all the land segments in the study area. Potentiometric maps (Brown and Caldwell, 1985) were also used to define the recharge area to the regional aquifer that supplied ground water to the Clear-Clarks Basin. The part of the recharge area outside the surface-water boundaries of the basin was divided into land segments, and the quantities of recharge from this area were computed and added to the Clear-Clarks Basin model to supply sufficient recharge to the simulated ground-water reservoir.

Simulation models were constructed at two scalescatchment models and basin models. Catchment models were constructed for several small basins on glacial till hillslopes where observed streamflow data were available for calibration. Process-related parameters, which define how runoff is produced for each type of land segment, were refined by calibration of the catchment models and constrained to a range of values consistent with the runoff processes defined in the conceptual model. Final calibrated parameters were used in all of the basin models. Two basin models were constructed for the six separate streams in the study area and calibrated to available streamflow data. It was shown that the influences of channel losses, regional ground-water flow paths and discharge, and channel detention storage not measured in the construction of the model were unique to each stream basin and required sufficient streamflow data-generally a minimum of 1 water year of continuous record at one or several sites in the basin-before accurate runoff simulation could be obtained.

The two time-series inputs to the simulation model, 15-minute precipitation and daily potential evapotranspiration, provided reasonably accurate representations of the 
two important hydrologic features that drive the simulated runoff processes. The rain-gage network of one gage per 14.5 square miles showed random variations of precipitation over the study area, having a maximum difference of 18.7 percent between annual totals at two different sites. Several storms with large precipitation totals were represented during the data-collection period, and a relatively dry water year (1992) was recorded. Potential evapotranspiration (PET) during the critical season for evapotranspiration was estimated from data from a nearby National Weather Service evaporation pan and a 0.75 pan coefficient. During the rainy season when PET was small and pan data were not collected, PET was estimated by application of the Jensen-Haise equation.

During the calibration process, simulated runoff from the catchment and basin models was compared with the first year of measured streamflow. Models were adjusted to minimize the differences between simulated and observed runoff. The largest difference in annual runoff for the final calibrated model was -4.65 inches or -14.7 percent for one of the catchment stream-gage sites and -9.3 percent for one of the basin stream-gage sites. Percent differences during winter and spring ranged from -29.5 to 8.7 percent. Summer runoff comparisons resulted in the highest percent differences (up to 83.3 percent), although actual runoff differences were low $(0.05 \mathrm{inch}$ at the same site). Three of the largest peak flows were compared at all the stream-gage sites. The largest difference was 80 cubic feet per second or -22.2 percent, and the largest percent difference was 66.2 percent $(4.5$ cubic feet per second). Two-thirds of the peak flow differences were less than 20.0 percent. Differences of simulated runoff volumes from observed runoff volumes ranged from -32.6 to 74.1 percent. Mean daily discharges had absolute errors ranging from 5.8 to 115.6 percent, bias ranging from -30.0 to 74.0 percent, and standard error of estimate ranging from 9.2 to 334.4 percent. The large percent errors were found in the simulation of low flow at sites that went dry in the summer and whose average absolute errors were generally small.

Simulated streamflow during the second year was also compared with observed streamflow to provide a validation of the simulation model. After the models were calibrated to the first year of observed data, no adjustments to the model were made, and the models were allowed to run for a second year. Annual runoff at one catchment site had a 25.7 percent difference between simulated and observed or an actual difference of 2.72 inches. The remainder of the sites had percent differences between -12.0 percent to 15.8 percent. Percent differences for winter and spring runoff varied from -28.9 to 42.2 percent. Summer runoff again had high percent differences (up to 700 percent), but the actual differences were small ( 0.07 inch at the same station). Two-thirds of the simulated peak flow percent differences from observed peak flows were less than 27.0 percent. Simulated storm-runoff volumes ranged from -22.9 to 84.6 percent difference from observed runoff volumes. Two-thirds of the percent differences were within 19 percent of the observed value. Mean daily discharges had absolute errors ranging from 8.6 to 197.7 percent, with the largest errors at stream gage sites that became dry during the year. Excluding these sites, the range was from 8.6 to 68.6 percent. Bias ranged from -31.2 to 112.3 percent, and standard error of estimate ranged from 10.7 to 906.8 percent. Again excluding the sites that became dry, bias ranged from -7.6 to 50.5 percent, and standard error of estimate ranged from 10.7 to 170.1 percent.

Auxiliary measurements of soil moisture and stream discharge measurements along a stream reach (seepage runs) proved to be valuable information for calibration and validation of the simulation model. Soil moisture measured at several locations at one of the catchment sites was used in the calibration process to measure how well the model simulated the transfer and storage of water in the soil zone. Observed soil moisture was compared graphically with simulated soil moisture, and values of simulated soil moisture from the final calibrated model fell within the range of values of observed soil moisture. Seepage runs along sections of channel reaches provided information on channel losses and ground-water gains. In some cases, channel losses were determined to be important and influenced peak discharges as well as low flows.

The model was generally successful in simulating the complex ground- and surface-water interactions in the study area. Use of the simulated ground-water reservoir to represent regional ground-water flow processes provided reasonably accurate simulations of runoff volumes and peak discharges. However, the simulation was too simple to simulate accurately ground-water travel times or the dynamic changes in ground-water flow paths, and as a result, the model did not always simulate the timing of peak flows or the correct shape of the storm hydrographs at the two Clover Creek gaging stations. These two stations are located in the large glacial outwash plain where the regional ground-water processes have a dominant influence on the storm hydrograph. In the Clear-Clarks Basin model, recharge was supplied to the ground-water reservoir from the area outside the Clear-Clarks Basin surface-water boundaries and within the ground-water flow boundaries in order to provide sufficient water to balance outflows to the Creeks. The simulated ground-water reser- 
voir in the Clear-Clarks Basin model accurately simulated regional ground-water inputs to Swan, Clear, and Diru Creeks that are a substantial percentage of the flow during low-flow periods (but only a small percentage during high-flow periods).

The fact that the simulation-model results match observations--within the range of errors that have been discussed--indicates that the conceptual model accurately describes the important hydrologic processes in central Pierce County. This indication is further reinforced by the consistency of the distribution of simulated runoff in various flow paths with the expected relative distribution outlined in the conceptual model. In general, the simulation model is a valid representation of the surface-water hydrology of the study area. The models can be expected to simulate actual flows within the range of discharges observed during this study and within a similar range of errors for subsequent runoff simulations. Long-term simulations have shown that the model is stable and that the 2 years of calibration and validation were representative of the long-term flows, especially peak flows, that can be expected in the study area. Because the model is simulating runoff according to realistic hydrologic principles appropriate for this region and because the validation simulations have been successful, it is reasonable to expect similar models constructed with sufficient streamflow information to simulate runoff accurately for other basins in the region within the same range of errors. The numerical model provides a tool with which land-use planners can assess the impacts of land development on streamflows. The numerical model was successful in reproducing the runoff processes in the conceptual model and simulation errors showed little bias of either under simulating or over simulating observed discharges for a range of land-use conditions. The numerical model should predict adequately the increase or decrease in streamflow caused by a particular change in land use more accurately than conventional methods, most of which have never been validated with measured data for the Pierce County area. Although the model may not always accurately reflect the absolute magnitude of streamflows, it should accurately reflect the change in streamflow resulting from land use changes, even from minor changes that have only a negligible effect on streamflow. In the case of simulating the cumulative effects of substantial land development on a watershed, the model should provide better estimates of the changes to streamflow characteristics than other available methods.

\section{REFERENCES CITED}

Alley, W.A., and Veenhuis, Jack E., 1983, Effective impervious area in urban runoff modeling: Journal of Hydraulic Engineering, v. 109, no. 2, February 1983, p. 313-319.

Anderson, D.G., 1970, Effects of urban development on floods in northern Virginia: U.S. Geological Survey Water-Supply Paper 2001-C, 22p.

Berris, S.N., 1995, Conceptualization and simulation of runoff generation from rainfall for three basins in Thurston County, Washington: U.S. Geological Survey Water-Resources Investigations Report 93-4038, 149 p.

Brown and Caldwell Consultants, 1985, Clover/Chambers Creek geohydrologic study: Seattle, Wash., Brown and Caldwell, unpaginated.

Burges, S.J., Stoker, B.A., Wigmosta, M.S., and Moeller, R.A., 1989, Hydrologic information and analyses required for mitigating hydrologic effects of urbanization: University of Washington Department of Civil Engineering Water Resources Series Technical Report No. 117, 131 p.

Crandell, D.R., Mullineaux, D.R., and Waldron, H.H., 1965, Age and origin of the Puget Sound trough in western Washington: U.S. Geological Survey Professional Paper 525-B, p. B132-B136.

Dinicola, R.S., 1990, Characterization and simulation of rainfall-runoff relations for headwater basins in western King and Snohomish Counties, Washington: U.S. Geological Survey Water-Resources Investigations Report 89-4052, 52 p.

Dunne, Thomas, and Black, R.D., 1970, Partial area contributions to storm runoff in a small New England watershed: Water Resources Research, v. 6, no. 5 p. $1,296-1,311$.

Dunne, Thomas, and Leopold, L.B., 1978, Water in environmental planning: San Francisco, W.H. Freeman and Company, $818 \mathrm{p}$. 
Farnsworth, R.K., and Thompson, E.S., 1982, Mean monthly, seasonal and annual pan evaporation for the United States: U.S. Department of Commerce, Office of Hydrology, National Weather Service, National Oceanographic and Atmospheric Administration Technical Report NWS 34, 82 p.

Federal Emergency Management Agency, 1987, Flood insurance study, Pierce County, Washington unincorporated areas: Washington, D.C., U.S. Federal Emergency Management Agency. v. 1, 81 p.

Hewlett, J.D., and Hibbert, A.R., 1967, Factors affecting the response of small watersheds to precipitation in humid regions, in Sopper, W.E., and Lull, H.W., ed., Forest hydrology: Oxford, Pergamon Press, p. 275-290.

Jensen, M.E., 1973, Consumptive use of water and irrigation water requirements: New York, American Society of Civil Engineers, Irrigation and Drainage Division, $215 \mathrm{p}$.

Laenen, Antonius, 1983, Storm runoff as related to urbanization based on data collected in Salem and Portland, and generalized for the Willamette Valley, Oregon: U.S. Geological Survey Water-Resources Investigations Report 83-4143, 88 p.

Linsley, R.K., Kohler, M.A., and Paulhus, J.L., 1982, Hydrology for engineers: San Francisco, McGraw-Hill Book Company, 508 p.

Pierce, A.J., Stewart, M.K., and Sklash, M.G., 1986, Storm runoff generation in humid headwater catchments-Where does the water come from?: Water Resources Research, v. 22, no. 8, p. 1,263-1,272.

Prych, E.A., and Ebbert, J.C., 1986, Quantity and quality of storm runoff from three urban catchments in Bellevue, Wash.: U.S. Geological Survey Water-Resources Investigations Report 86-4000, 85 p.
Savini, John, and Kammerer, J.C., 1961, Urban growth and the water regimen: U.S. Geological Water-Supply Paper 1591-A, 42 p.

Seaburn, G.E., 1969, Effects of urban development on direct runoff to East Meadow Brook, Nassau County, Long Island, New York: U.S. Geological Survey Professional Paper 627-B, 14 p.

Topp, G.C., and Davis, J.L., 1985, Measurement of soil water content using time-domain reflectometry (TDR)-a field evaluation: Soil Science Society of America Journal, v. 49, p. 19-24.

U.S. Department of Agriculture, 1979, Soil survey of Pierce County area, Washington: U.S. Department of Agriculture Soil Conservation Service, 131 p.

U.S. Department of Commerce, 1973, Precipitationfrequency atlas of the western United States, Volume D-Washington: Silver Spring, Maryland, National Oceanic and Atmospheric Administration, NOAA Atlas 2, 43 p.

1982, Climatography of the United States, no. 81 (by state)-Monthly normals of temperature, precipitation, and heating and cooling degree days 1951-80 Washington: Asheville, North Carolina, National Oceanic and Atmospheric Administration.

1989-1992, Climatological data annual summary, Washington: National Oceanic and Atmospheric Administration, v. 93-96.

U.S. Environmental Protection Agency, 1984, Hydrological simulation program-FORTRAN (HSPF)-Users manual for release 8.0: Athens, Georgia, Environmental Research Laboratory, EPA-600/3-84-066, 767 p.

Walters, K.L., and Kimmel, G.E., 1968, Ground-water occurrence and stratigraphy of unconsolidated deposits, central Pierce County, Washington: Washington Department of Natural Resources Water-Supply Bulletin no. 22, 428 p. 


\section{SUPPLEMENTARY DATA}

The input sequence of the two basin models is shown in this section (tables 15 and 16). The input sequence--also known as the user control input (UCI) files--specifies the operations to be performed by the HSPF model during a simulation, the parameters and initial conditions for the run, and the time series to be used during the run and how they are to be passed between operations. The UCI files are arranged in blocks of programming that begin with a heading (such as PERLND) and end with a delimiter (such as END PERLND). Lines that contain three or more consecutive asterisks $\left({ }^{* * *}\right)$ are ignored by HSPF and are used for comments to aid in interpreting the UCI file. 
Table 15.--Input sequence of the Clear-Clarks Basin model used to run Hydrological Simulation Program-FORTRAN (HSPF)

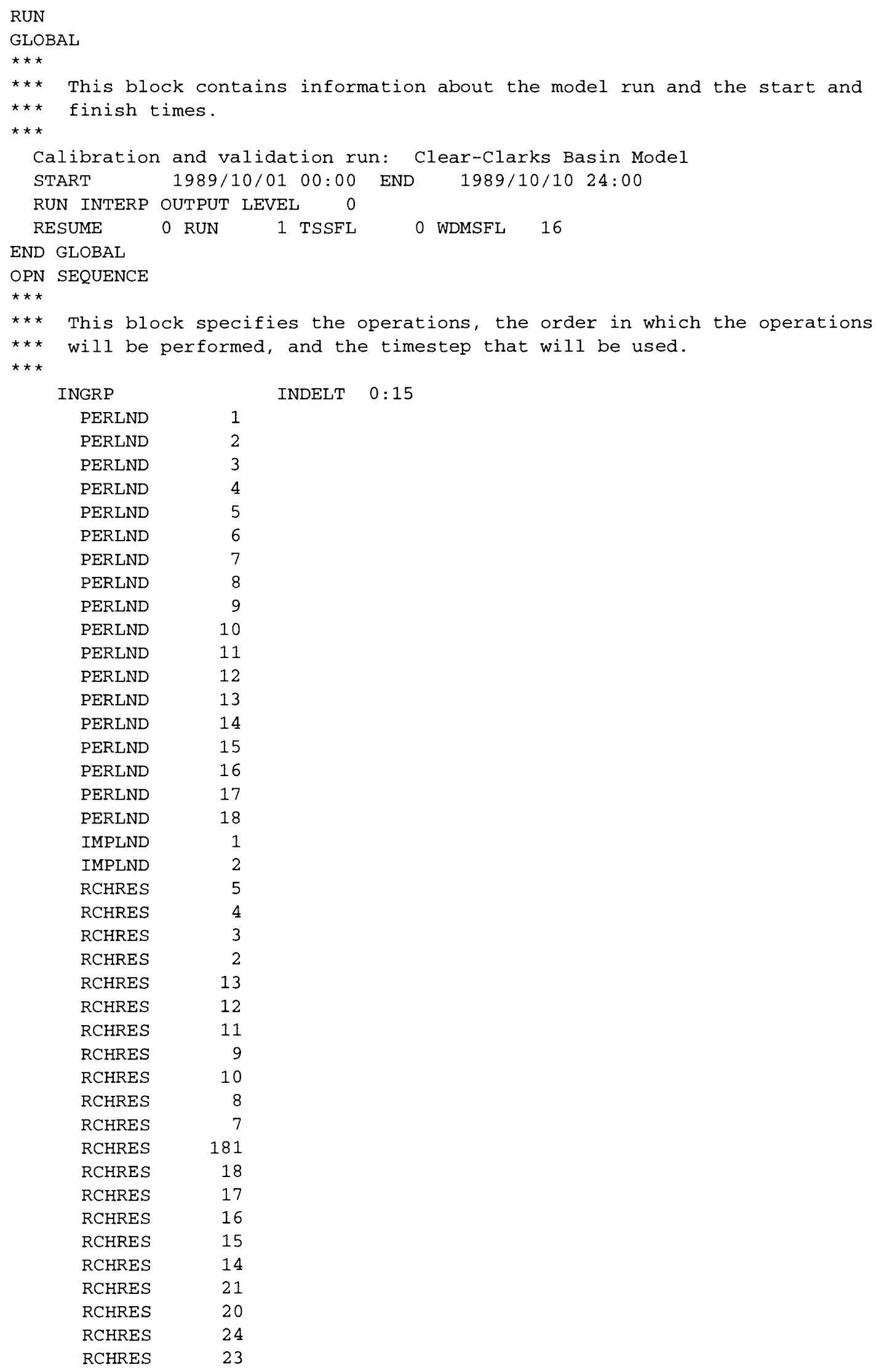


Table 15.--Input sequence of the Clear-Clarks Basin model used to run Hydrological Simulation Program-FORTRAN (HSPF)--Cont.

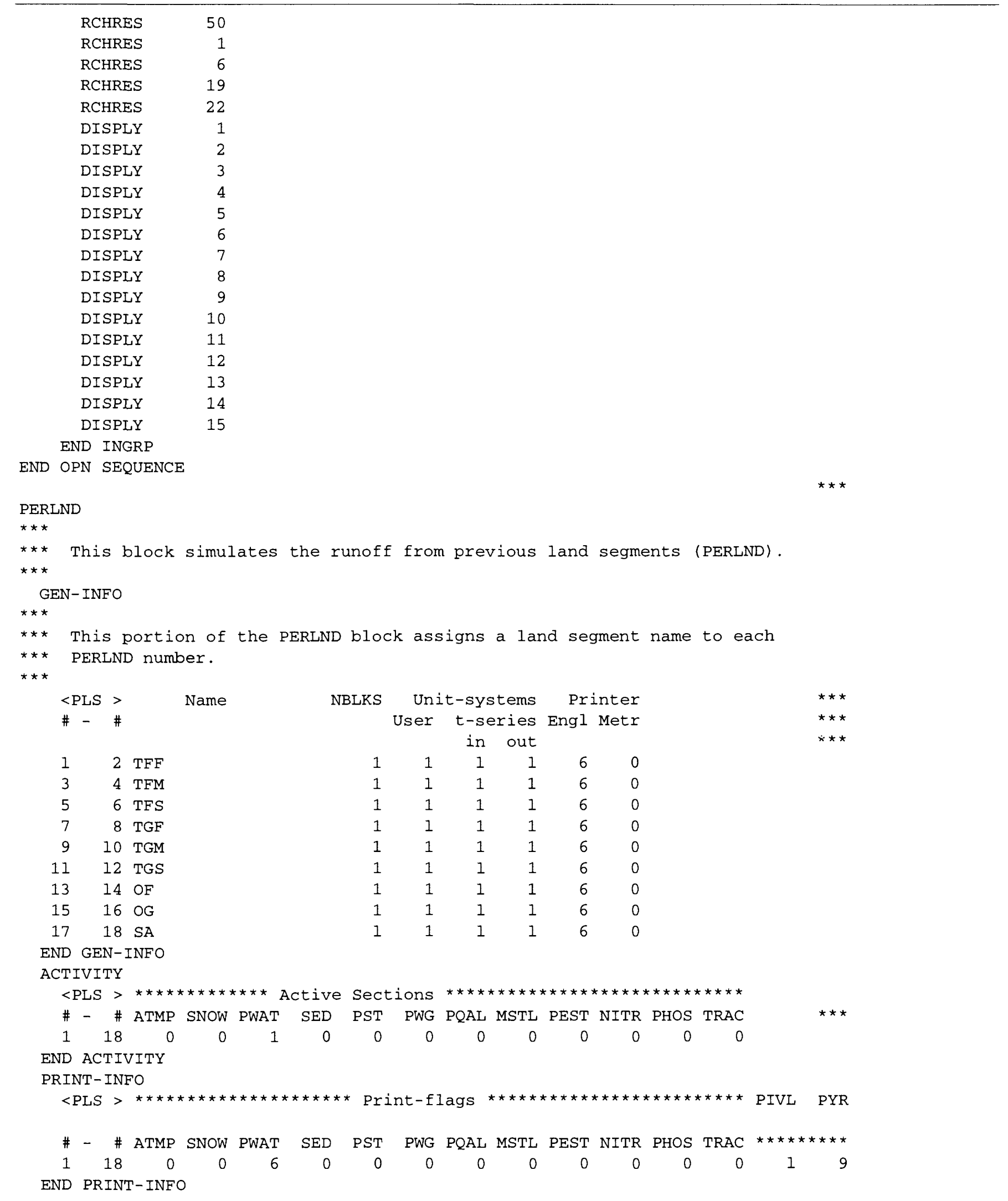


Table 15.--Input sequence of the Clear-Clarks Basin model used to run Hydrological Simulation Program-FORTRAN (HSPF)-Cont.

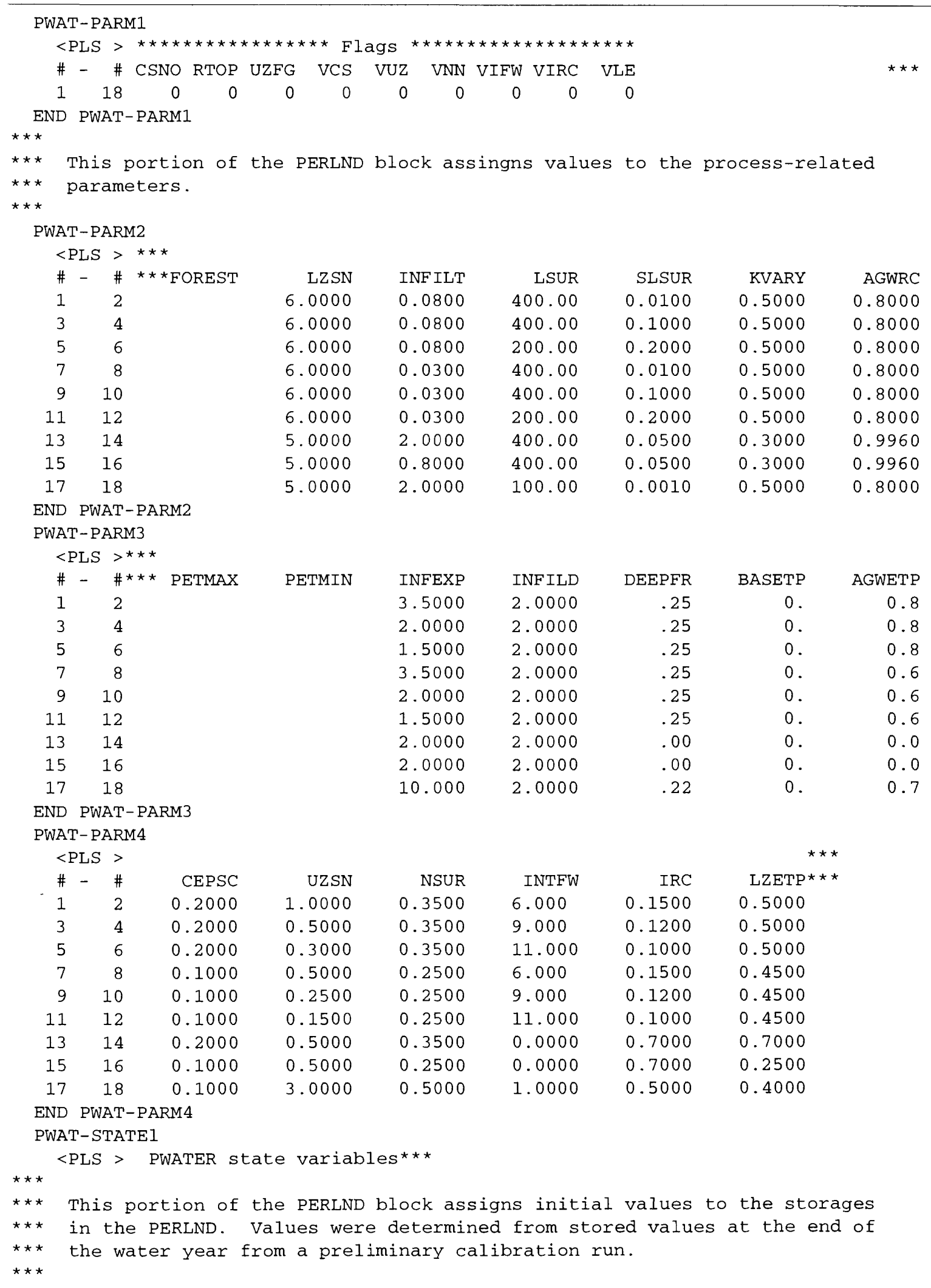


Table 15.--Input sequence of the Clear-Clarks Basin model used to run Hydrological Simulation Program-FORTRAN (HSPF)--Cont.

\begin{tabular}{|c|c|c|c|c|c|c|c|c|}
\hline$<$ PLS & \multicolumn{2}{|c|}{ PWATER state } & \multicolumn{2}{|c|}{ variables*** } & \multirow[b]{2}{*}{ IFWS } & \multirow[b]{2}{*}{ LZS } & \multirow[b]{2}{*}{ AGWS } & \multirow[b]{2}{*}{ GWVS } \\
\hline \# & $-\quad \# \star \star \star$ & CEPS & SURS & UZS & & & & \\
\hline 1 & 2 & 0.00 & 0 & 0.001 & 0 & 0.43 & 0.00 & 0.006 \\
\hline 3 & 4 & 0.00 & 0 . & 0.001 & 0 . & 0.37 & 0.00 & 0.006 \\
\hline 5 & 6 & 0.00 & 0. & 0.001 & 0. & 0.33 & 0.00 & 0.006 \\
\hline 7 & 8 & 0.00 & 0 . & 0.001 & 0 . & 0.59 & 0.00 & 0.004 \\
\hline 9 & 10 & 0.00 & 0. & 0.001 & 0 & 0.51 & 0.00 & 0.003 \\
\hline 11 & 12 & 0.00 & 0. & 0.001 & 0. & 0.46 & 0.00 & 0.003 \\
\hline 13 & 14 & 0.00 & 0 . & 0.001 & 0 . & 0.05 & 5.81 & 0.073 \\
\hline 15 & 16 & 0.00 & 0 . & 0.001 & 0 . & 2.82 & 6.33 & 0.145 \\
\hline 17 & 18 & 0.00 & 0. & 0.263 & 0. & 2.79 & 0.004 & 0.081 \\
\hline
\end{tabular}

END PWAT-STATE1

END PERLND

IMPLND

$\star \star *$

*** This block provides the information for simulation of runoff from the

$\star \star \star$ impervious (IMPLND) land segments.

$\star \star *$

GEN-INFO

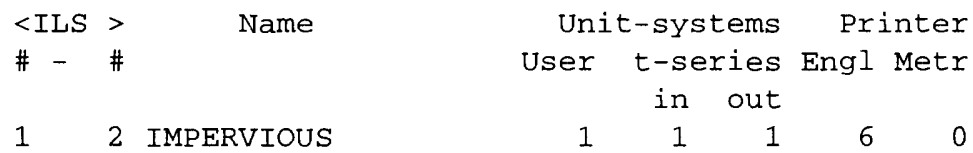

END GEN-INFO

ACTIVITY

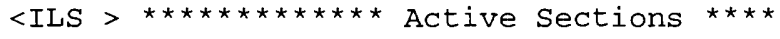

\# - \# ATMP SNOW IWAT SLD IWG IQAL ***

$\begin{array}{llllllll}1 & 2 & 0 & 0 & 1 & 0 & 0 & 0\end{array}$

END ACTIVITY

PRINT-INFO

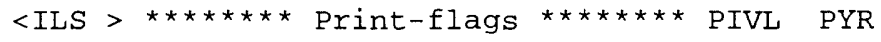

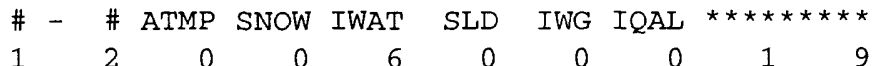

END PRINT-INFO

IWAT-PARM1

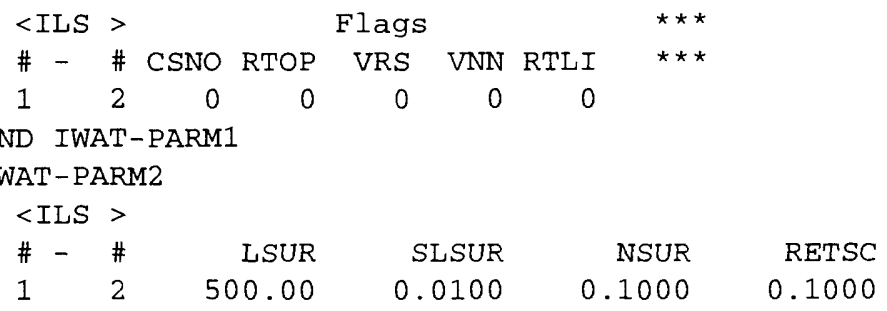

END IWAT-PARM2

IWAT-PARM3

<ILS >

\# - \# PETMAX PETMIN

12

END IWAT-PARM3

$* * \star$

$* \star *$ Intial values for storages in the IMPLND land segment.

IWAT-STATE 1

$\begin{array}{lccc}<\text { ILS } & \text { IWATER state } & \text { variables } \\ \#- & \# & \text { RETS } & \text { SURS } \\ 1 & 2 & 0.001 & 0.001\end{array}$

$120.001 \quad 0.001$ 


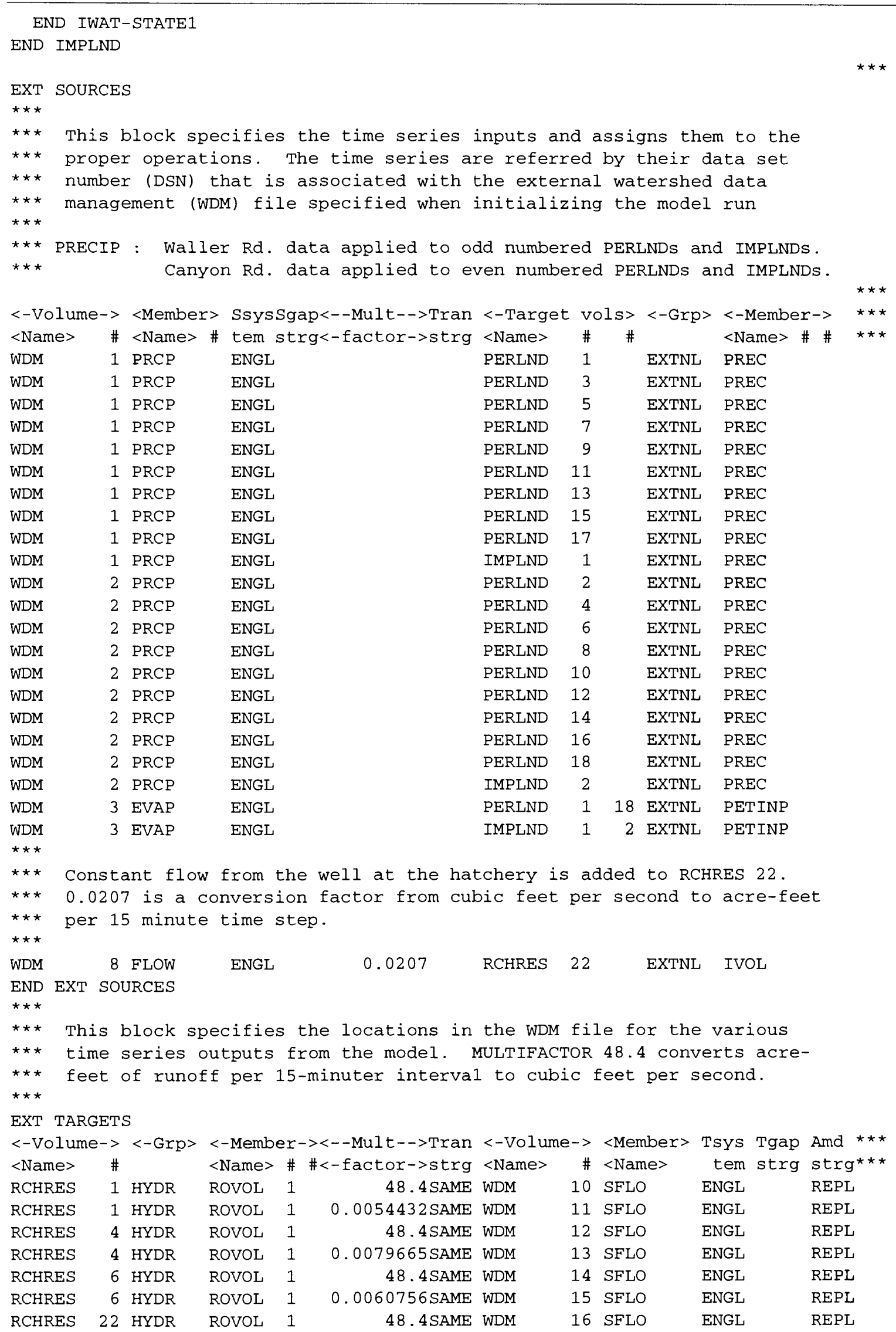


Table 15.--Input sequence of the Clear-Clarks Basin model used to run Hydrological Simulation Program-FORTRAN (HSPF)--Cont.

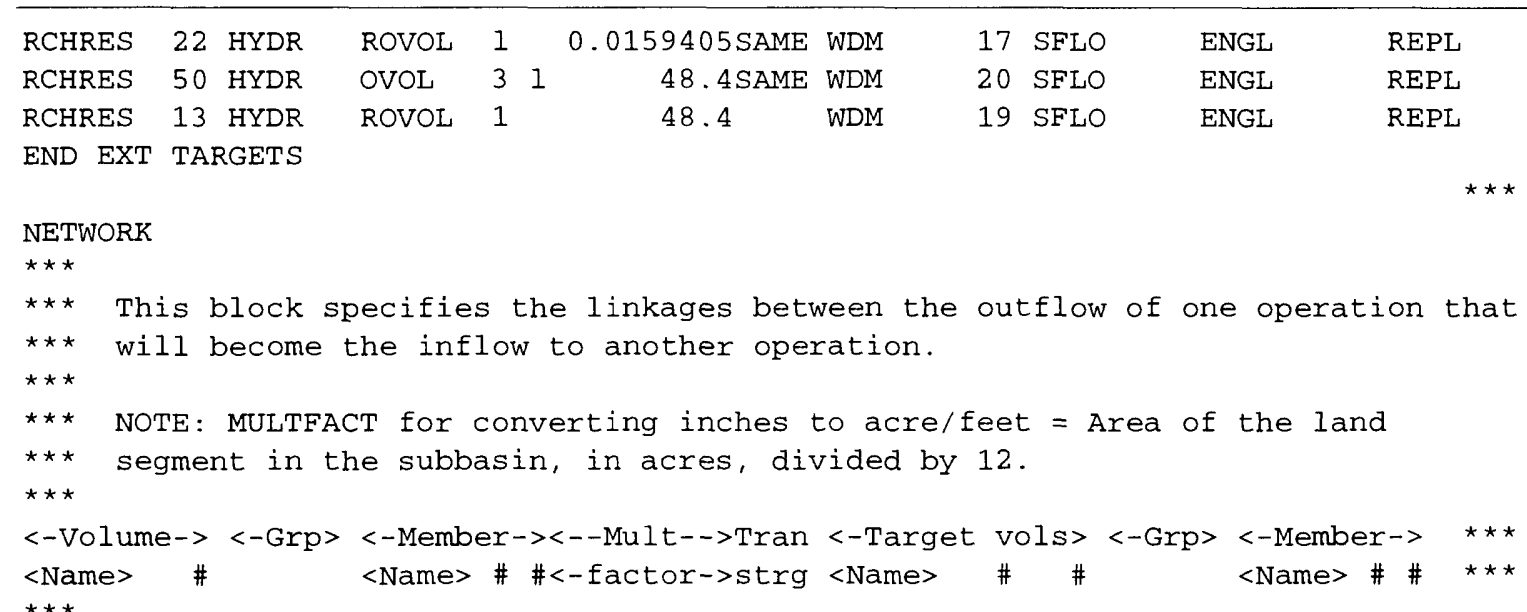

$\star \star \star$

$\star \star \star$ SWAN CREEK BASIN

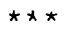

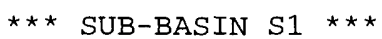

PERLND 2 PWATER PERO

PERLND 2 PWATER IGWI

6.191 RCHRES 5 EXTNL IVOL

PERLND 8 PWATER PERO

6.191 RCHRES 50

EXTNL IVOL

PERLND 8 PWATER IGWI

56.270

RCHRES 5

56.270

PERLND 18 PWATER PERO

9.221

PERLND 18 PWATER IGWI

9.221

RCHRES 50

EXTNL IVOL

EXTNL IVOL

IMPLND 2 IWATER SURO

RCHRES 5

EXTNL IVOL

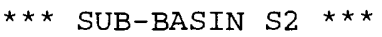

PERIND 2 PWATER PERO

PERLND 2 PWATER IGWI

6.086

RCHRES 50

EXTNL IVOI

6.086 RCHRES 4 EXTNL IVOL

6.086

0.492

PERIND 4 PWATER PERO

0.492

PERLND 4 PWATER IGWI

27.669

PERLND 8 PWATER PERO

27.669

PERLND 8 PWATER IGWI

PERIND 10 PWATER PERO

PERLND 10 PWATER IGWI

0.592

0.592

PERIND 18 PWATER PERO

9. 260

RCHRES 50

EXTNL IVOL

RCHRES 4 EXTNL IVOL

RCHRES 50 EXTNL IVOL

PERLND 18 PWATER IGWI

9. 260

IMPLND 2 IWATER SURO

1. 567

RCHRES 4

EXTNL IVOL

EXTNL IVOL

EXTNL IVOL

RCHRES 50

EXTNL IVOI

EXTNL IVOL

EXTNL IVOL

** * SUB-BASIN S3 ***

PERIND 1 PWATER PERO

3.732

RCHRES 50

RCHRES 4

RCHRES 50

EXTNL IVOL

PERLND 1 PWATER IGWI

3. 732

RCHRES 4

EXTNL IVOL

EXTNL IVOL

0.055

RCHRES 3

RCHRES 50

EXTNL IVOL

PERLND 3 PWATER IGWI

0.055

RCHRES 3

RCHRES 50

2. 950

2.950

RCHRES 3

PERLND 7 PWATER IGWI

0.194

RCHRES 50

RCHRES 3

0.194

PERLND 9 PWATER IGWI

0.381

RCHRES 50

PERLND 17 PWATER PERO

0.381

PERLND 17 PWATER IGWI

IMPLND 1 IWATER SURO

0.231

RCHRES 3

RCHRES 50

** * SUB-BASIN S4 ***

4.591

RCHRES 3

EXTNL IVOL

EXTNL IVOL

EXTNL IVOI

EXTNL IVOL

EXTNL IVOL

EXTNL IVOL

EXTNL IVOL

EXTNL IVOL

PERLND 1 PWATER PERO

4. 591

RCHRES 2

EXTNL IVOL

0.895

RCHRES 50

EXTNL IVOL

0.895

RCHRES 2

EXTNL IVOL

$\begin{array}{llll}\text { PERLND } & 3 & \text { PWATER PERO } \\ \text { PERLND } & 3 & \text { PWATER } & \text { IGWI }\end{array}$

RCHRES 50

EXTNL IVOL 
Table 15.--Input sequence of the Clear-Clarks Basin model used to run Hydrological Simulation Program-FORTRAN (HSPF)--Cont.

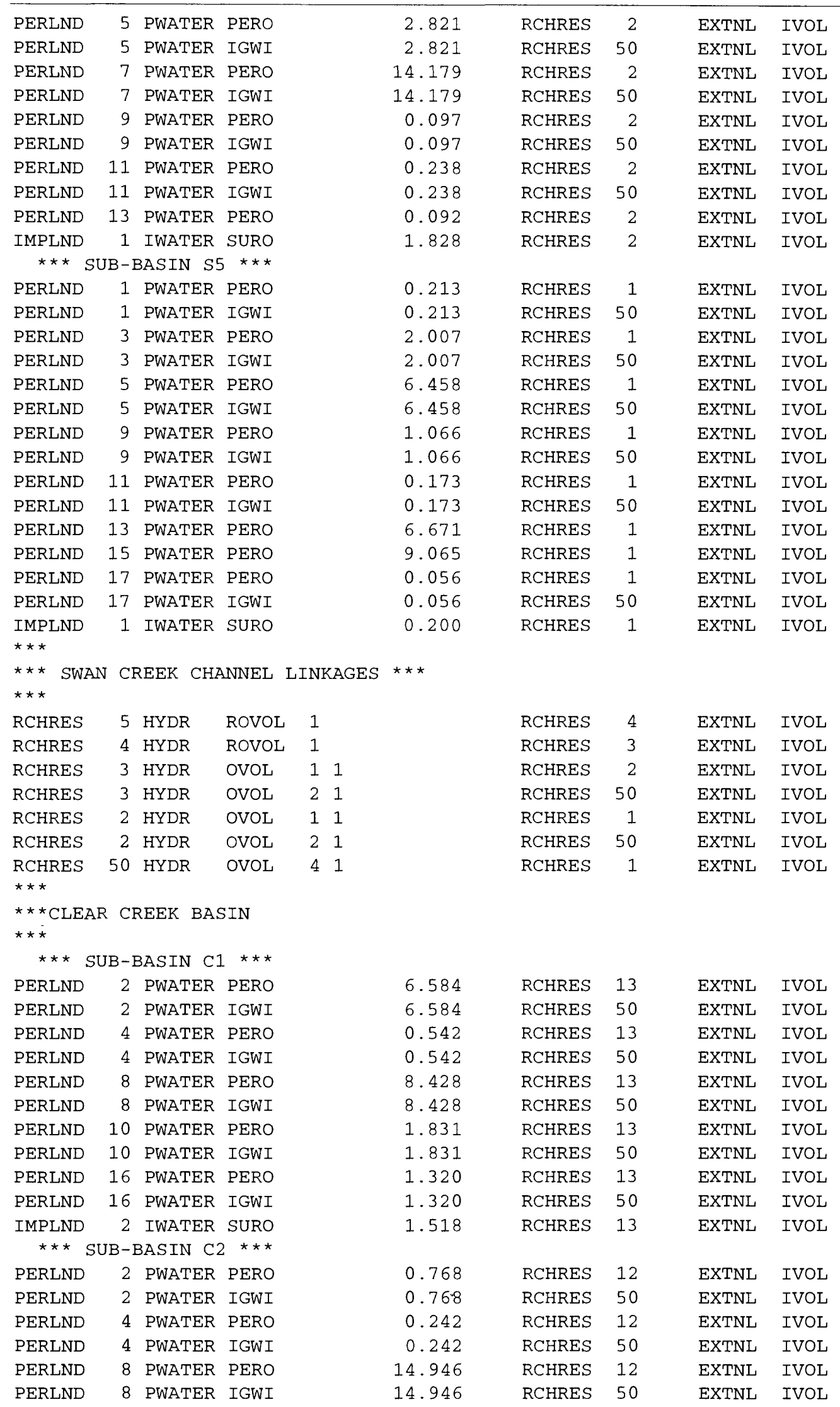


Table 15.--Input sequence of the Clear-Clarks Basin model used to run Hydrological Simulation Program-FORTRAN (HSPF)--Cont.

\begin{tabular}{|c|c|c|c|c|c|c|c|}
\hline PERLND & 10 & PWATER PERO & 0.862 & RCHRES & 12 & EXTNL & IVOL \\
\hline PERLND & 10 & PWATER IGWI & 0.862 & RCHRES & 50 & EXTNL & IVOL \\
\hline PERLND & 16 & PWATER PERO & 1.848 & RCHRES & 12 & EXTNL & IVOL \\
\hline PERLND & 16 & PWATER IGWI & 1.848 & RCHRES & 50 & EXTNL & IVOL \\
\hline IMPLND & 2 & IWATER SURO & 1.587 & RCHRES & 12 & EXTNL & IVOL \\
\hline \multicolumn{8}{|c|}{$\star \star \star$ SUB-BASIN C $3 \star \star \star \star$} \\
\hline PERLND & 2 & PWATER PERO & 10.338 & RCHRES & 11 & EXTNL & IVOL \\
\hline PERLND & 2 & PWATER IGWI & 10.338 & RCHRES & 50 & EXTNL & IVOL \\
\hline PERLND & 4 & PWATER PERO & 1.119 & RCHRES & 11 & EXTNL & IVOL \\
\hline PERLND & 4 & PWATER IGWI & 1.119 & RCHRES & 50 & EXTNL & IVOL \\
\hline PERLND & 6 & PWATER PERO & 0.027 & RCHRES & 11 & EXTNL & IVOL \\
\hline PERLND & 6 & PWATER IGWI & 0.027 & RCHRES & 50 & EXTNL & IVOL \\
\hline PERLND & 8 & PWATER PERO & 19.950 & RCHRES & 11 & EXTNL & IVOL \\
\hline PERLND & 8 & PWATER IGWI & 19.950 & RCHRES & 50 & EXTNL & IVOL \\
\hline PERLND & 10 & PWATER PERO & 2.694 & RCHRES & 11 & EXTNL & IVOL \\
\hline PERLND & 10 & PWATER IGWI & 2.694 & RCHRES & 50 & EXTNL & IVOL \\
\hline PERLND & 12 & PWATER PERO & 0.011 & RCHRES & 11 & EXTNL & IVOL \\
\hline PERLND & 12 & PWATER IGWI & 0.011 & RCHRES & 50 & EXTNL & IVOL \\
\hline PERLND & 15 & PWATER PERO & 0.308 & RCHRES & 11 & EXTNL & IVOL \\
\hline PERLND & 18 & PWATER PERO & 3.387 & RCHRES & 11 & EXTNL & IVOL \\
\hline PERLND & 18 & PWATER IGWI & 3.387 & RCHRES & 50 & EXTNL & IVOL \\
\hline IMPLND & 2 & IWATER SURO & 1.080 & RCHRES & 11 & EXTNL & IVOL \\
\hline \multicolumn{8}{|c|}{$\star \star \star$ SUB-BASIN C $4 \quad \star \star \star *$} \\
\hline PERLND & 1 & PWATER PERO & 1.437 & RCHRES & 10 & EXTNL & IVOL \\
\hline PERLND & 1 & PWATER IGWI & 1.437 & RCHRES & 50 & EXTNL & IVOL \\
\hline PERLND & 3 & PWATER PERO & 0.354 & RCHRES & 10 & EXTNL & IVOL \\
\hline PERLND & 3 & PWATER IGWI & 0.354 & RCHRES & 50 & EXTNL & IVOL \\
\hline PERLND & 5 & PWATER PERO & 1.799 & RCHRES & 10 & EXTNL & IVOL \\
\hline PERLND & 5 & PWATER IGWI & 1.799 & RCHRES & 50 & EXTNL & IVOL \\
\hline PERLND & 7 & PWATER PERO & 4.933 & RCHRES & 10 & EXTNL & IVOL \\
\hline PERLND & 7 & PWATER IGWI & 4.933 & RCHRES & 50 & EXTNL & IVOL \\
\hline PERLND & 9 & PWATER PERO & 0.079 & RCHRES & 10 & EXTNL & IVOL \\
\hline PERLND & 9 & PWATER IGWI & 0.079 & RCHRES & 50 & EXTNL & IVOL \\
\hline PERLND & 11 & PWATER PERO & 0.219 & RCHRES & 10 & EXTNL & IVOL \\
\hline PERLND & 11 & PWATER IGWI & 0.219 & RCHRES & 50 & EXTNL & IVOL \\
\hline IMPLND & 1 & IWATER SURO & 0.488 & RCHRES & 10 & EXTNL & IVOL \\
\hline \multicolumn{8}{|c|}{ 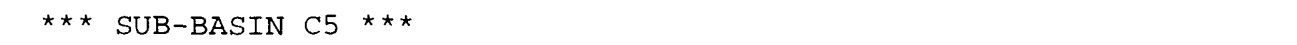 } \\
\hline PERLND & 2 & PWATER PERO & 1.734 & RCHRES & 9 & EXTNL & IVOL \\
\hline PERLND & 2 & PWATER IGWI & 1.734 & RCHRES & 50 & EXTNL & IVOL \\
\hline PERLND & 4 & PWATER PERO & 0.359 & RCHRES & 9 & EXTNL & IVOL \\
\hline PERLND & 4 & PWATER IGWI & 0.359 & RCHRES & 50 & EXTNL & IVOL \\
\hline PERLND & 8 & PWATER PERO & 14.011 & RCHRES & 9 & EXTNL & IVOL \\
\hline PERLND & 8 & PWATER IGWI & 14.011 & RCHRES & 50 & EXTNL & IVOL \\
\hline PERLND & 10 & PWATER PERO & 3.314 & RCHRES & 9 & EXTNL & IVOL \\
\hline PERLND & 10 & PWATER IGWI & 3.314 & RCHRES & 50 & EXTNL & IVOL \\
\hline PERLND & 16 & PWATER PERO & 4.222 & RCHRES & 9 & EXTNL & IVOL \\
\hline PERLND & 16 & PWATER IGWI & 4.222 & RCHRES & 50 & EXTNL & IVOL \\
\hline IMPLND & 2 & IWATER SURO & 0.762 & RCHRES & 9 & EXTNL & IVOL \\
\hline \multicolumn{8}{|c|}{$\star \star \star$ SUB-BASIN C $6 \quad * \star \star$} \\
\hline PERLND & 1 & PWATER PERO & 4.195 & RCHRES & 8 & EXTNL & IVOL \\
\hline PERLND & 1 & PWATER IGWI & 4.195 & RCHRES & 50 & EXTNL & IVOL \\
\hline PERLND & 3 & PWATER PERO & 0.210 & RCHRES & 8 & EXTNL & IVOL \\
\hline PERLND & 3 & PWATER IGWI & 0.210 & RCHRES & 50 & EXTNL & IVOL \\
\hline PERLND & 5 & PWATER PERO & 2.906 & RCHRES & 8 & EXTNL & IVOL \\
\hline PERLND & 5 & PWATER IGWI & 2.906 & RCHRES & 50 & EXTNL & IVOL \\
\hline PERLND & 7 & PWATER PERO & 11.228 & RCHRES & 8 & EXTNL & IVOL \\
\hline PERLND & 7 & PWATER IGWI & 11.228 & RCHRES & 50 & EXTNL & IVOL \\
\hline PERLND & 9 & PWATER PERO & 1.146 & RCHRES & 8 & EXTNL & IVOL \\
\hline PERLND & 9 & PWATER IGWI & 1.146 & RCHRES & 50 & EXTNL & IVOL \\
\hline
\end{tabular}


Table 15.--Input sequence of the Clear-Clarks Basin model used to run Hydrological Simulation Program-FORTRAN (HSPF)--Cont.

\begin{tabular}{|c|c|c|c|c|c|c|c|c|c|}
\hline PERLND & 11 & PWATER & PERO & & 1.732 & RCHRES & 8 & EXTNL & IVOL \\
\hline PERLND & 11 & PWATER & IGWI & & 1.732 & RCHRES & 50 & EXTNL & IVOL \\
\hline \multirow{2}{*}{\multicolumn{10}{|c|}{$\begin{array}{l}\text { IMPLND } 1 \text { IWATER SURO } \\
* * * \text { SUB-BASIN C7 } \\
\star \star *\end{array}$}} \\
\hline & & & & & & & & & \\
\hline PERLND & 1 & PWATER & PERO & & 3.049 & RCHRES & 7 & EXTNL & IVOL \\
\hline PERLND & 1 & PWATER & IGWI & & 3.049 & RCHRES & 50 & EXTNL & IVOL \\
\hline PERLND & 3 & PWATER & PERO & & 0.021 & RCHRES & 7 & EXTNL & IVOL \\
\hline PERLND & 3 & PWATER & IGWI & & 0.021 & RCHRES & 50 & EXTNL & IVOL \\
\hline PERLND & 5 & PWATER & PERO & & 5.554 & RCHRES & 7 & EXTNL & IVOL \\
\hline PERLND & 5 & PWATER & IGWI & & 5.554 & RCHRES & 50 & EXTNL & IVOL \\
\hline PERLND & 7 & PWATER & PERO & & 4.548 & RCHRES & 7 & EXTNL & IVOL \\
\hline PERLND & 7 & PWATER & IGWI & & 4.548 & RCHRES & 50 & EXTNL & IVOL \\
\hline PERLND & 9 & PWATER & PERO & & 0.917 & RCHRES & 7 & EXTNL & IVOL \\
\hline PERLND & 9 & PWATER & IGWI & & 0.917 & RCHRES & 50 & EXTNL & IVOL \\
\hline PERLND & 11 & PWATER & PERO & & 2.463 & RCHRES & 7 & EXTNL & IVOL \\
\hline PERLND & 11 & PWATER & IGWI & & 2.463 & RCHRES & 50 & EXTNL & IVOL \\
\hline PERLND & 13 & PWATER & PERO & & 0.998 & RCHRES & 7 & EXTNL & IVOL \\
\hline PERLND & 14 & PWATER & PERO & & 2.140 & RCHRES & 7 & EXTNL & IVOL \\
\hline \multirow{2}{*}{\multicolumn{10}{|c|}{$\begin{array}{l}\text { IMPLND } 1 \text { IWATER SURO } \\
\star \star \star \\
\text { SUB-BASIN C } 8 * \star\end{array}$}} \\
\hline & & & & & & & & & \\
\hline PERLND & 1 & PWATER & PERO & & 1.353 & RCHRES & 6 & EXTNL & IVOL \\
\hline PERLND & 1 & PWATER & IGWI & & 1.353 & RCHRES & 50 & EXTNL & IVOL \\
\hline PERLND & 3 & PWATER & PERO & & 0.290 & RCHRES & 6 & EXTNL & IVOL \\
\hline PERLND & 3 & PWATER & IGWI & & 0.290 & RCHRES & 50 & EXTNL & IVOL \\
\hline PERLND & 5 & PWATER & PERO & & 1.693 & RCHRES & 6 & EXTNL & IVOL \\
\hline PERLND & 5 & PWATER & IGWI & & 1.693 & RCHRES & 50 & EXTNL & IVOL \\
\hline PERLND & 7 & PWATER & PERO & & 2.329 & RCHRES & 6 & EXTNL & IVOL \\
\hline PERLND & 7 & PWATER & IGWI & & 2.329 & RCHRES & 50 & EXTNL & IVOL \\
\hline PERLND & 9 & PWATER & PERO & & 1.839 & RCHRES & 6 & EXTNL & IVOL \\
\hline PERLND & 9 & PWATER & IGWI & & 1.839 & RCHRES & 50 & EXTNL & IVOL \\
\hline PERLND & 11 & PWATER & PERO & & 0.586 & RCHRES & 6 & EXTNL & IVOL \\
\hline PERLND & 11 & PWATER & IGWI & & 0.586 & RCHRES & 50 & EXTNL & IVOL \\
\hline PERLND & 13 & PWATER & PERO & & 0.196 & RCHRES & 6 & EXTNL & IVOL \\
\hline PERLND & 14 & PWATER & PERO & & 0.308 & RCHRES & 6 & EXTNL & IVOL \\
\hline IMPLND & 1 & IWATER & SURO & & 0.597 & RCHRES & 6 & EXTNL & IVOL \\
\hline \multicolumn{10}{|l|}{$\star \star \star$} \\
\hline \multicolumn{2}{|c|}{$\begin{array}{l}\star \star \star \text { CLEAR } \\
\star \star \star\end{array}$} & CREEK CF & HANNEL & LINKAGES & $\star \star \star$ & & & & \\
\hline RCHRES & 13 & HYDR & ROVOL & 1 & & RCHRES & 11 & EXTNL & IVOL \\
\hline RCHRES & 12 & HYDR & ROVOL & 1 & & RCHRES & 11 & EXTNL & IVOL \\
\hline RCHRES & 11 & HYDR & OVOL & 11 & & RCHRES & 10 & EXTNL & IVOL \\
\hline RCHRES & 11 & HYDR & OVOL & 21 & & RCHRES & 50 & EXTNL & IVOL \\
\hline RCHRES & 11 & HYDR & OVOL & 21 & & COPY & 2 & INPUT & MEAN \\
\hline RCHRES & 10 & HYDR & OVOL & 11 & & RCHRES & 7 & EXTNL & IVOL \\
\hline RCHRES & 10 & HYDR & OVOL & 21 & & RCHRES & 50 & EXTNL & IVOL \\
\hline RCHRES & 10 & HYDR & OVOL & 21 & & COPY & 2 & INPUT & MEAN \\
\hline RCHRES & 9 & HYDR & ROVOL & 1 & & RCHRES & 8 & EXTNL & IVOL \\
\hline RCHRES & 8 & HYDR & OVOL & 11 & & RCHRES & 7 & EXTNL & IVOL \\
\hline RCHRES & 8 & HYDR & OVOL & 21 & & RCHRES & 50 & EXTNL & IVOL \\
\hline RCHRES & 8 & HYDR & OVOL & 21 & & COPY & 2 & INPUT & MEAN \\
\hline RCHRES & 7 & HYDR & OVOL & 11 & & RCHRES & 6 & EXTNL & IVOL \\
\hline RCHRES & 7 & HYDR & OVOL & 21 & & RCHRES & 50 & EXTNL & IVOL \\
\hline RCHRES & 7 & HYDR & OVOL & 21 & & COPY & 2 & INPUT & MEAN \\
\hline $\begin{array}{l}\text { RCHRES } \\
\star \star \star\end{array}$ & 50 & HYDR & OVOL & 31 & & RCHRES & 6 & EXTNL & IVOL \\
\hline$\star \star \star \quad C A N$ & $\mathrm{CON}$ & CREEK & BASIN & & & & & & \\
\hline$\star \star \star$ & & & & & & & & & \\
\hline$\star * *$ On & & & & & & & & & \\
\hline
\end{tabular}


Table 15.--Input sequence of the Clear-Clarks Basin model used to run Hydrological Simulation Program-FORTRAN (HSPF)--Cont.

\begin{tabular}{|c|c|c|c|c|c|c|c|}
\hline \multicolumn{8}{|l|}{$\star \star \star$} \\
\hline \multicolumn{8}{|c|}{$\star \star \star$ SUB-BASIN CAN $1 * \star \star \star$} \\
\hline PERLND & 2 & PWATER PERO & 5.001 & RCHRES & 181 & EXTNL & IVOL \\
\hline PERLND & 2 & PWATER IGWI & 5.001 & RCHRES & 50 & EXTNL & IVOL \\
\hline PERLND & 4 & PWATER PERO & 2.617 & RCHRES & 181 & EXTNL & IVOL \\
\hline PERLND & & PWATER IGWI & 2.617 & RCHRES & 50 & EXTNL & IVOL \\
\hline PERLND & 8 & PWATER PERO & 17.574 & RCHRES & 181 & EXTNL & IVOL \\
\hline PERLND & 8 & PWATER IGWI & 17.574 & RCHRES & 50 & EXTNL & IVOL \\
\hline PERLND & 10 & PWATER PERO & 6.947 & RCHRES & 181 & EXTNL & IVOL \\
\hline PERLND & 10 & PWATER IGWI & 6.947 & RCHRES & 50 & EXTNL & IVOL \\
\hline IMPLND & 2 & IWATER SURO & 4.242 & RCHRES & 18 & EXTNL & IVOL \\
\hline \multicolumn{8}{|c|}{$\star \star \star$ SUB-BASIN CAN2 $\star \star \star \star$} \\
\hline PERLND & 2 & PWATER PERO & 4.114 & RCHRES & 17 & EXTNL & IVOL \\
\hline PERLND & 2 & PWATER IGWI & 4.114 & RCHRES & 50 & EXTNL & IVOL \\
\hline PERLND & 4 & PWATER PERO & 1.944 & RCHRES & 17 & EXTNL & IVOL \\
\hline PERLND & 4 & PWATER IGWI & 1.944 & RCHRES & 50 & EXTNL & IVOL \\
\hline PERLND & 8 & PWATER PERO & 4.746 & RCHRES & 17 & EXTNL & IVOL \\
\hline PERLND & 8 & PWATER IGWI & 4.746 & RCHRES & 50 & EXTNL & IVOL \\
\hline PERLND & 10 & PWATER PERO & 3.289 & RCHRES & 17 & EXTNL & IVOL \\
\hline PERLND & 10 & PWATER IGWI & 3.289 & RCHRES & 50 & EXTNL & IVOL \\
\hline PERLND & 18 & PWATER PERO & 2.825 & RCHRES & 17 & EXTNL & IVOL \\
\hline PERLND & 18 & PWATER IGWI & 2.825 & RCHRES & 50 & EXTNL & IVOL \\
\hline IMPLND & 2 & IWATER SURO & 3.421 & RCHRES & 17 & EXTNL & IVOL \\
\hline \multicolumn{8}{|c|}{$\star \star \star$ SUB-BASIN CAN $3 \star \star \star$} \\
\hline PERLND & 2 & PWATER PERO & 0.484 & RCHRES & 16 & EXTNL & IVOL \\
\hline PERLND & 2 & PWATER IGWI & 0.484 & RCHRES & 50 & EXTNL & IVOL \\
\hline PERLND & 4 & PWATER PERO & 1.140 & RCHRES & 16 & EXTNL & IVOL \\
\hline PERLND & & PWATER IGWI & 1.140 & RCHRES & 50 & EXTNL & IVOL \\
\hline PERLND & 6 & PWATER PERO & 0.339 & RCHRES & 16 & EXTNL & IVOL \\
\hline PERLND & 6 & PWATER IGWI & 0.339 & RCHRES & 50 & EXTNL & IVOL \\
\hline PERLND & 8 & PWATER PERO & 3.258 & RCHRES & 16 & EXTNL & IVOL \\
\hline PERLND & 8 & PWATER IGWI & 3.258 & RCHRES & 50 & EXTNL & IVOL \\
\hline PERLND & 10 & PWATER PERO & 4.812 & RCHRES & 16 & EXTNL & IVOL \\
\hline PERLND & 10 & PWATER IGWI & 4.812 & RCHRES & 50 & EXTNL & IVOL \\
\hline IMPLND & 2 & IWATER SURO & 1.938 & RCHRES & 16 & EXTNL & IVOL \\
\hline \multicolumn{8}{|c|}{$\star \star \star$ SUB-BASIN CAN $4 * \star \star$} \\
\hline PERLND & 1 & PWATER PERO & 3.030 & RCHRES & 15 & EXTNL & IVOL \\
\hline PERLND & 1 & PWATER IGWI & 3.030 & RCHRES & 50 & EXTNL & IVOL \\
\hline PERLND & 3 & PWATER PERO & 0.172 & RCHRES & 15 & EXTNL & IVOL \\
\hline PERLND & 3 & PWATER IGWI & 0.172 & RCHRES & 50 & EXTNL & IVOL \\
\hline PERLND & 5 & PWATER PERO & 1.397 & RCHRES & 15 & EXTNL & IVOL \\
\hline PERLND & 5 & PWATER IGWI & 1.397 & RCHRES & 50 & EXTNL & IVOL \\
\hline PERLND & 7 & PWATER PERO & 14.077 & RCHRES & 15 & EXTNL & IVOL \\
\hline PERLND & 7 & PWATER IGWI & 14.077 & RCHRES & 50 & EXTNL & IVOL \\
\hline PERLND & 9 & PWATER PERO & 2.954 & RCHRES & 15 & EXTNL & IVOL \\
\hline PERLND & 9 & PWATER IGWI & 2.954 & RCHRES & 50 & EXTNL & IVOL \\
\hline PERLND & 11 & PWATER PERO & 0.522 & RCHRES & 15 & EXTNL & IVOL \\
\hline PERLND & 11 & PWATER IGWI & 0.522 & RCHRES & 50 & EXTNL & IVOL \\
\hline IMPLND & 1 & IWATER SURO & 3.243 & RCHRES & 15 & EXTNL & IVOL \\
\hline \multicolumn{8}{|c|}{$\star \star \star$ SUB-BASIN CAN5 $\star \star \star$} \\
\hline PERLND & 1 & PWATER PERO & 3.800 & RCHRES & 14 & EXTNL & IVOL \\
\hline PERLND & 1 & PWATER IGWI & 3.800 & RCHRES & 50 & EXTNL & IVOL \\
\hline PERLND & 3 & PWATER PERO & 0.567 & RCHRES & 14 & EXTNL & IVOL \\
\hline PERLND & 3 & PWATER IGWI & 0.567 & RCHRES & 50 & EXTNL & IVOL \\
\hline PERLND & 5 & PWATER PERO & 4.902 & RCHRES & 14 & EXTNL & IVOL \\
\hline PERLND & 5 & PWATER IGWI & 4.902 & RCHRES & 50 & EXTNL & IVOL \\
\hline PERLND & 7 & PWATER PERO & 12.026 & RCHRES & 14 & EXTNL & IVOL \\
\hline PERLND & 7 & PWATER IGWI & 12.026 & RCHRES & 50 & EXTNL & IVOL \\
\hline PERLND & 9 & PWATER PERO & 0.706 & RCHRES & 14 & EXTNL & IVOL \\
\hline
\end{tabular}


Table 15.--Input sequence of the Clear-Clarks Basin model used to run Hydrological Simulation Program-FORTRAN (HSPF)--Cont.

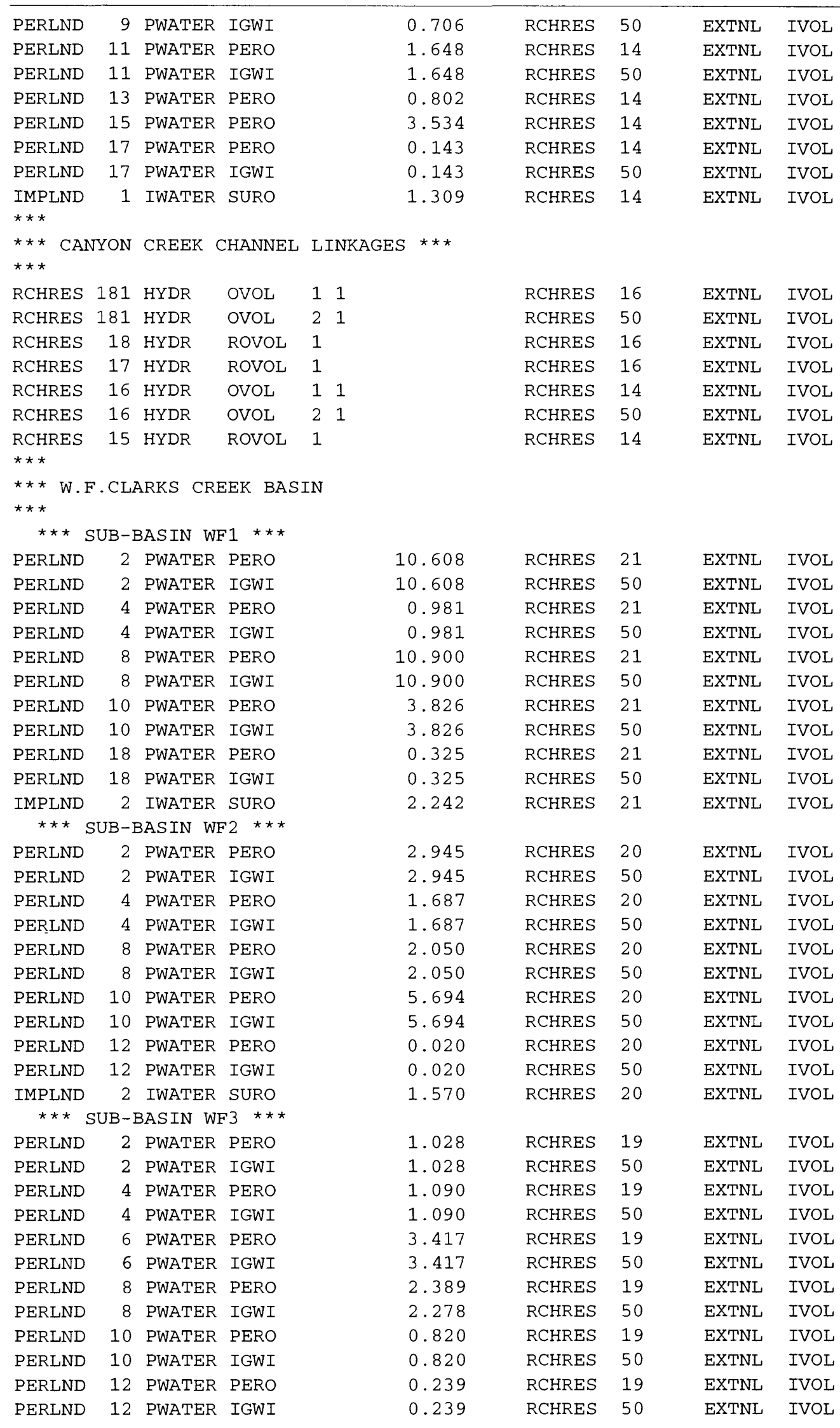


Table 15.--Input sequence of the Clear-Clarks Basin model used to run Hydrological Simulation Program-FORTRAN (HSPF)--Cont.

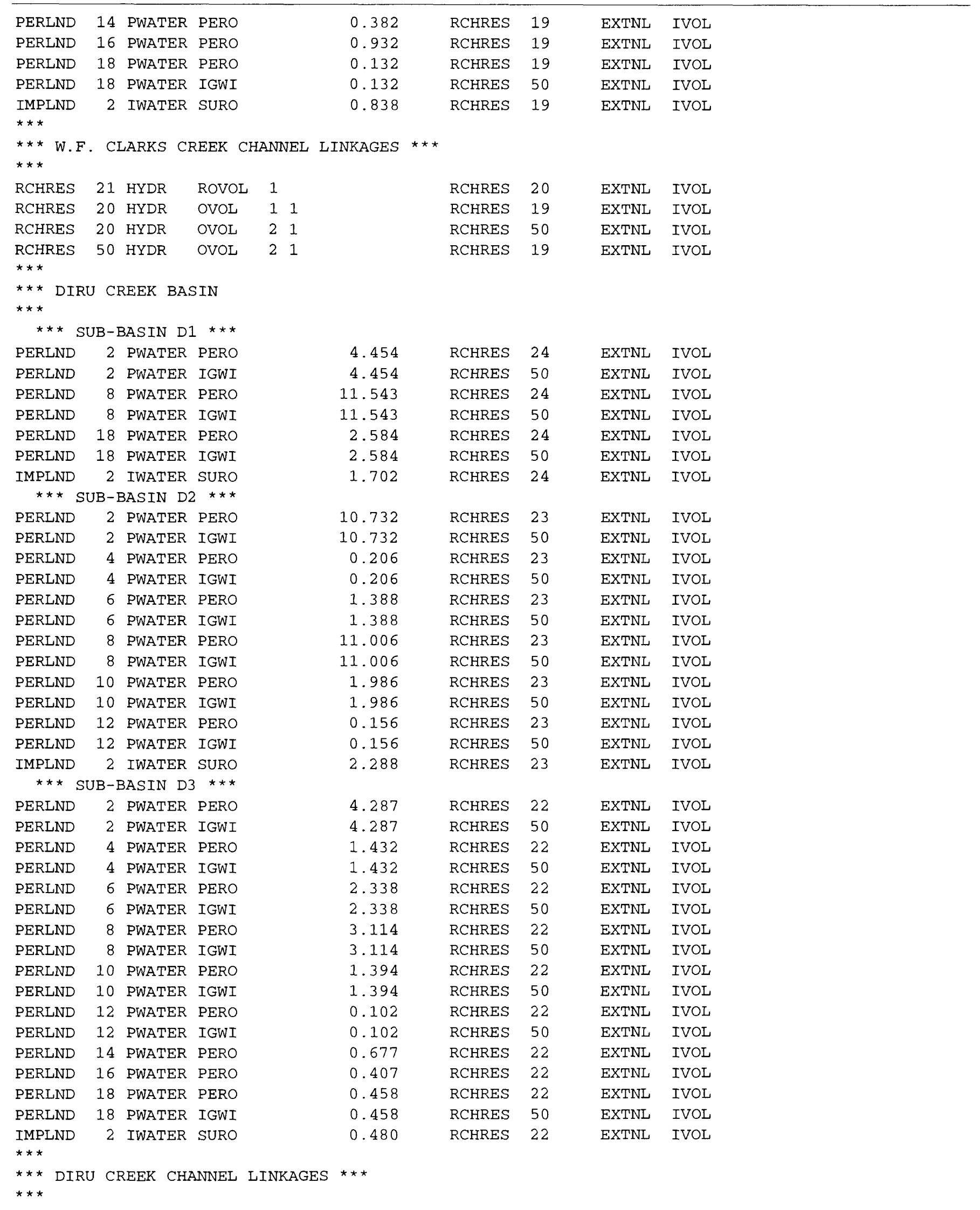


Table 15.--Input sequence of the Clear-Clarks Basin model used to run Hydrological Simulation Program-FORTRAN (HSPF)--Cont.

\begin{tabular}{|c|c|c|c|c|c|c|c|c|c|}
\hline RCHRES & 24 & HYDR & ROVOL & 1 & & RCHRES & 23 & EXTNL & IVOL \\
\hline RCHRES & 23 & HYDR & OVOL & 11 & & RCHRES & 22 & EXTNL & IVOL \\
\hline RCHRES & 23 & HYDR & OVOL & 21 & & RCHRES & 50 & EXTNL & IVOL \\
\hline $\begin{array}{l}\text { RCHRES } \\
\star \star \star\end{array}$ & 50 & HYDR & OVOL & 11 & & RCHRES & 22 & EXTNL & IVOL \\
\hline \multirow{2}{*}{\multicolumn{10}{|c|}{ 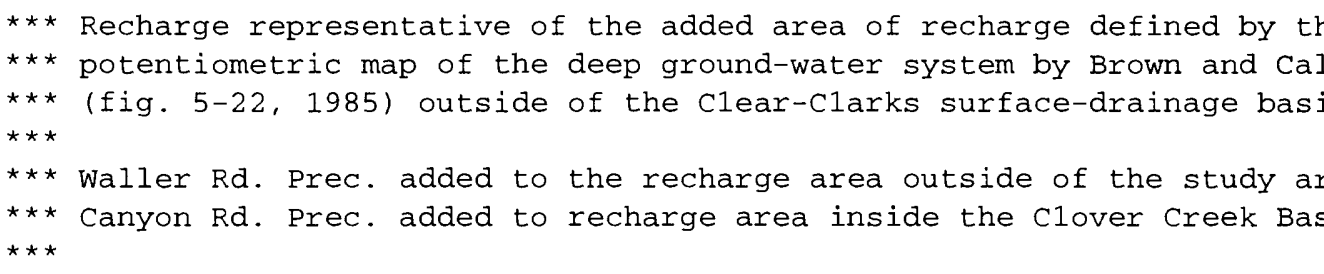 }} \\
\hline & & & & & & & & & \\
\hline PERLND & 1 & PWATER & IGWI & & 4.267 & RCHRES & 50 & EXTNL & IVOL \\
\hline PERLND & 2 & PWATER & IGWI & & & RCHRES & 50 & XTNL & IVOL \\
\hline PERLND & 4 & PWATER & IGWI & & 15.8 & RCHRES & 5 & EXTNL & IVOL \\
\hline PERLND & 6 & PWATER & IGWI & & 1.6 & RCHRES & 50 & EXTNL & IVOL \\
\hline PERLND & 7 & PWATER & IGWI & & 103.8 & RCHRES & 50 & EXTNL & IVOL \\
\hline PERLND & 8 & PWATER & IGWI & & 188.45 & RCHRES & 50 & EXTNL & IVOL \\
\hline PERLND & 10 & PWATER & IGWI & & 13.0 & RCHRES & 50 & EXTNL & IVOL \\
\hline PERLND & 12 & PWATER & IGWI & & 1.08 & RCHRES & 50 & EXTNL & IVOL \\
\hline PERLND & 13 & PWATER & AGWO & & 4.45 & RCHRES & 50 & EXTNL & IVOL \\
\hline PERLND & 14 & PWATER & AGWO & & 0.84 & RCHRES & 50 & EXTNL & IVOL \\
\hline PERLND & 15 & PWATER & AGWO & & 9.050 & RCHRES & 50 & EXTNL & IVOL \\
\hline PERLND & 16 & PWATER & AGWO & & 1.058 & RCHRES & 50 & EXTNL & IVOL \\
\hline PERLND & 18 & PWATER & IGWI & & 20.867 & RCHRES & 50 & EXTNL & IVOL \\
\hline
\end{tabular}

$$
\star \star \star * \text { DISPLAY OF PEAK DISCHARGES } * \star *
$$$$
\star \star \star
$$$$
1 \text { HYDR }
$$$$
\text { RCHRES } 3 \text { HYDR }
$$$$
\text { RCHRES } 4 \text { HYDR }
$$

RCHRES 5 HYDR

RCHRES 6 HYDR

RCHRES 9 HYDR

RCHRES 11 HYDR

RCHRES 13 HYDR

RCHRES 16 HYDR

RCHRES 19 HYDR

RCHRES 21 HYDR

$\begin{array}{lll}\text { ROVOL } & 1 & \\ \text { OVOL } & 1 & 1 \\ \text { ROVOL } & 1 & \\ \text { ROVOL } & 1 & \\ \text { ROVOL } & 1 & \\ \text { ROVOL } & 1 & \\ \text { OVOL } & 1 & 1 \\ \text { ROVOL } & 1 & \\ \text { OVOL } & 1 & 1 \\ \text { ROVOL } & 1 & \\ \text { ROVOL } & 1 & \end{array}$

48.4

DISPLY 1

DISPLY 2

48.4 DISPLY 3

48.4

DISPLY

48.4

DISPLY

48.4

DISPLY

DISPLY

DISPLY

48.4

DISPLY

48.4

DISPIY 10

48.4

DISPLY 11

$\begin{array}{lll}\text { INPUT } & \text { TIMSER } & 1 \\ \text { INPUT } & \text { TIMSER } & 1 \\ \text { INPUT } & \text { TIMSER } & 1 \\ \text { INPUT } & \text { TIMSER } & 1 \\ \text { INPUT } & \text { TIMSER } & 1 \\ \text { INPUT } & \text { TIMSER } & 1 \\ \text { INPUT } & \text { TIMSER } & 1 \\ \text { INPUT } & \text { TIMSER } & 1 \\ \text { INPUT } & \text { TIMSER } & 1 \\ \text { INPUT } & \text { TIMSER } & 1 \\ \text { INPUT } & \text { TIMSER } & 1\end{array}$

$\star \star \star$

$\star \star \star$ DISPLAY OF INCHES OF RUNOFF

$\star \star \star *$

RCHRES 1 HYDR

RCHRES 4 HYDR

RCHRES 6 HYDR

RCHRES 22 HYDR

END NETWORK

48.4

$\star \star \star *$

RCHRES

$\begin{array}{lll}\text { ROVOL } & 1 & 0.0054432 \\ \text { ROVOL } & 1 & 0.0079665 \\ \text { ROVOL } & 1 & 0.0060756 \\ \text { ROVOL } & 1 & 0.0159405\end{array}$

ROVOL 10.0159405

$\begin{array}{ll}\text { DISPLY } & 12 \\ \text { DISPLY } & 13 \\ \text { DISPLY } & 14 \\ \text { DISPLY } & 15\end{array}$

INPUT TIMSER 1 INPUT TIMSER 1 INPUT TIMSER 1 INPUT TIMSER 1

\footnotetext{
...

*** This block simulates streamflows in stream reaches and outflows from

$* * *$ the ground-water reservoir.

$\star \star \star$

GEN-INFO
} 
Table 15.--Input sequence of the Clear-Clarks Basin model used to run Hydrological Simulation Program-FORTRAN (HSPF)--Cont.

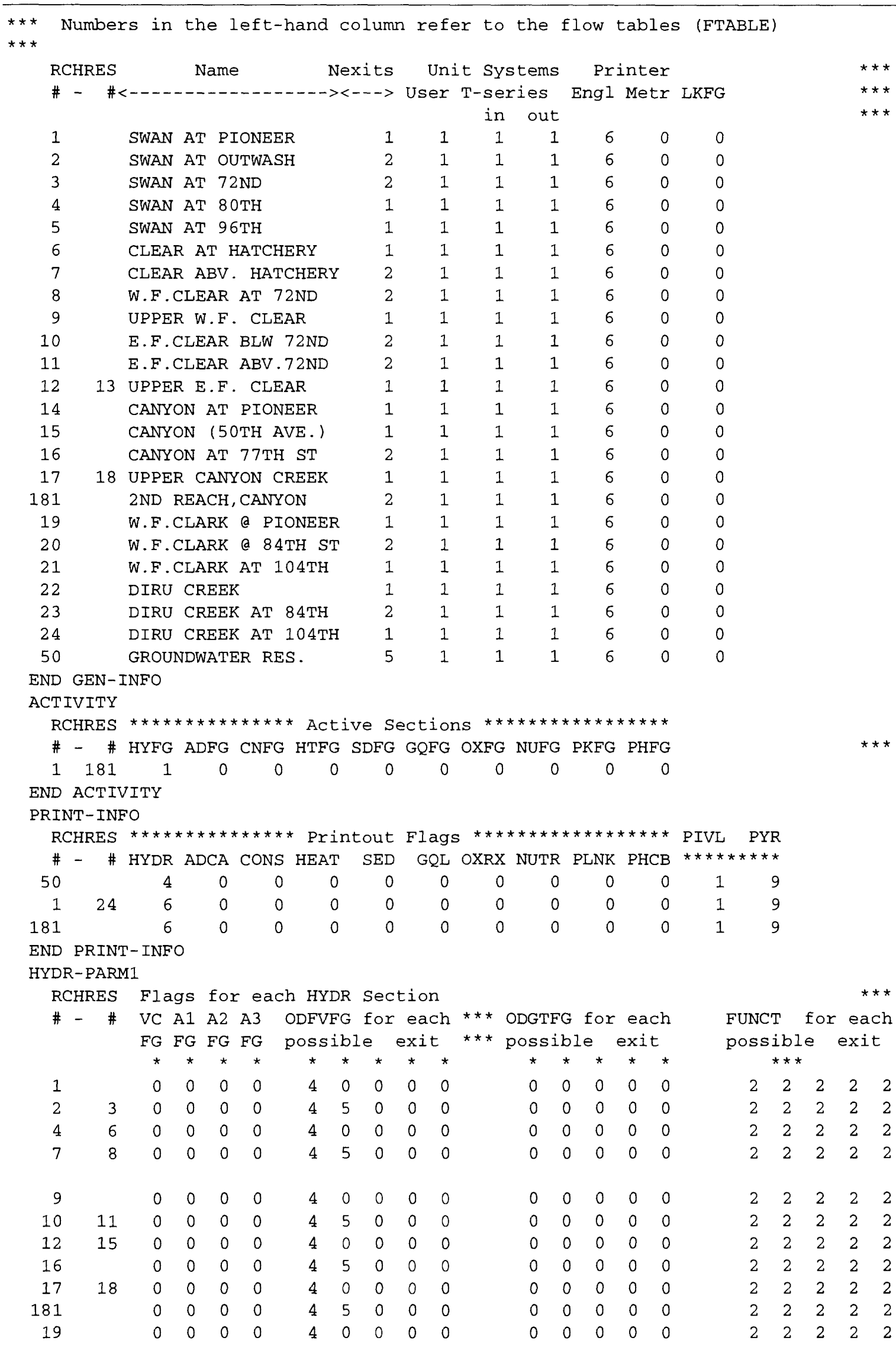


Table 15.--Input sequence of the Clear-Clarks Basin model used to run Hydrological Simulation Program-FORTRAN (HSPF)--Cont.

\begin{tabular}{lllllllllllllllllllllllll}
\hline 20 & & 0 & 0 & 0 & 0 & 4 & 5 & 0 & 0 & 0 & 0 & 0 & 0 & 0 & 0 & 2 & 2 & 2 & 2 & 2 \\
21 & 22 & 0 & 0 & 0 & 0 & 4 & 0 & 0 & 0 & 0 & & 0 & 0 & 0 & 0 & 0 & & 2 & 2 & 2 & 2 & 2 \\
23 & & 0 & 0 & 0 & 0 & 4 & 5 & 0 & 0 & 0 & & 0 & 0 & 0 & 0 & 0 & & 2 & 2 & 2 & 2 & 2 \\
24 & & 0 & 0 & 0 & 0 & 4 & 0 & 0 & 0 & 0 & & 0 & 0 & 0 & 0 & 0 & & 2 & 2 & 2 & 2 & 2 \\
50 & & 0 & 0 & 0 & 0 & 4 & 5 & 6 & 7 & 8 & & 0 & 0 & 0 & 0 & 0 & & 2 & 2 & 2 & 2 & 2
\end{tabular}

END HYDR-PARM1

HYDR-PARM2

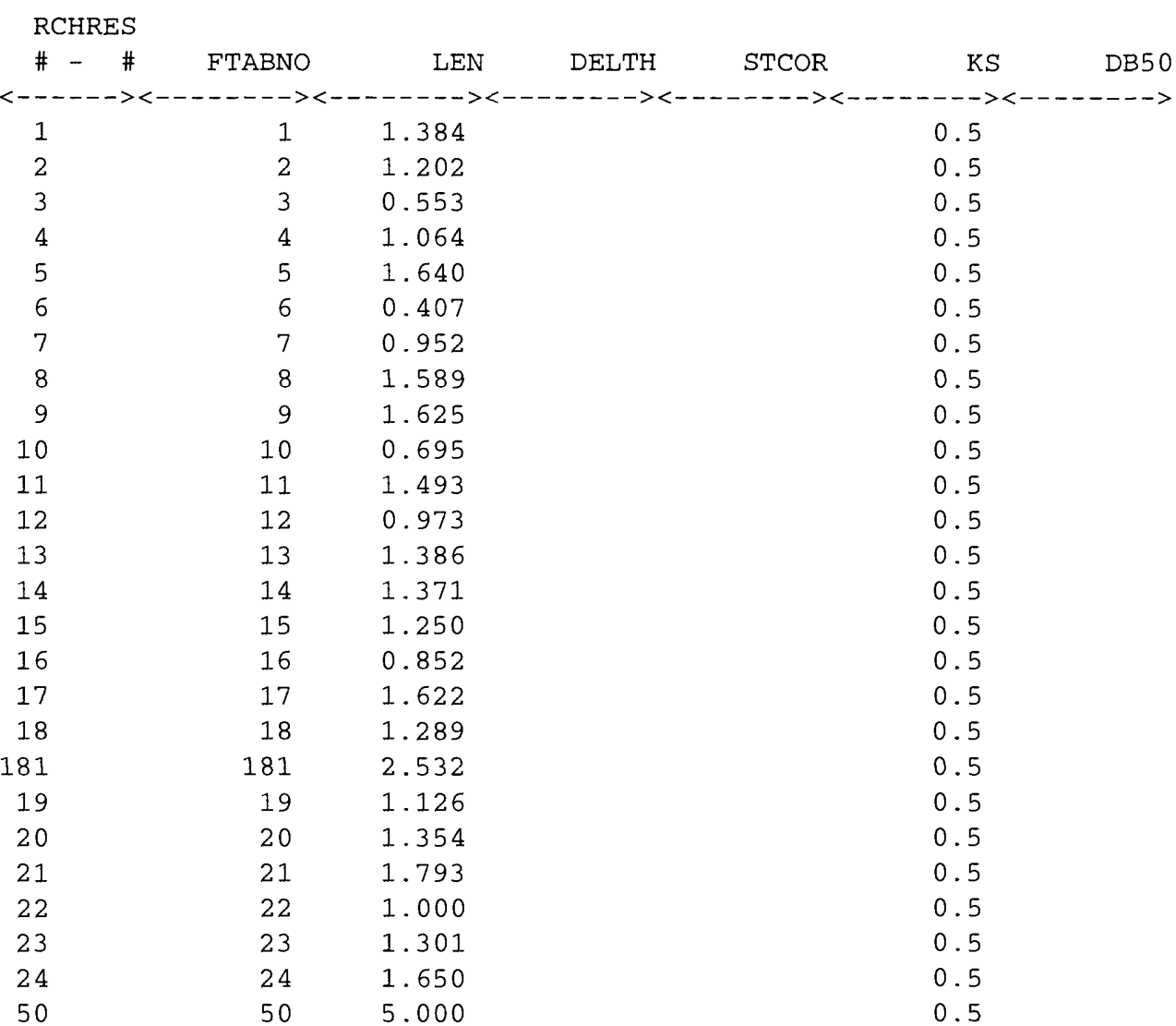

END HYDR-PARM2

HYDR-INIT

RCHRES Initial conditions for each HYDR section

$\#-\# * * *$ VOL Initial value of COLIND

Initial value of OUTDGT $\star \star \star$ ac $-\mathrm{ft}$

for each possible exit for each possible exit

\begin{tabular}{|c|c|c|c|c|}
\hline \multicolumn{2}{|c|}{$<------><--------->$} & \multirow{2}{*}{\multicolumn{3}{|c|}{$<---><---><---><---><--->* * *<---><---><---><---><--->$}} \\
\hline 1 & 0.070 & & & \\
\hline 2 & 0.000 & 4.0 & 5.0 & \\
\hline 3 & 0.000 & 4.0 & 5.0 & \\
\hline 4 & 0.000 & 4.0 & & \\
\hline 5 & 0.000 & 4.0 & & \\
\hline 6 & 0.150 & 4.0 & & \\
\hline 7 & 0.200 & 4.0 & 5.0 & \\
\hline 8 & 0.000 & 4.0 & 5.0 & \\
\hline 9 & 0.000 & 4.0 & & \\
\hline 10 & 0.000 & 4.0 & 5.0 & \\
\hline 11 & 0.000 & 4.0 & 5.0 & \\
\hline 12 & 0.000 & 4.0 & & \\
\hline 13 & 0.000 & 4.0 & & \\
\hline 14 & 0.200 & 4.0 & & \\
\hline 15 & 0.000 & 4.0 & & \\
\hline 16 & 0.000 & 4.0 & 5.0 & \\
\hline
\end{tabular}




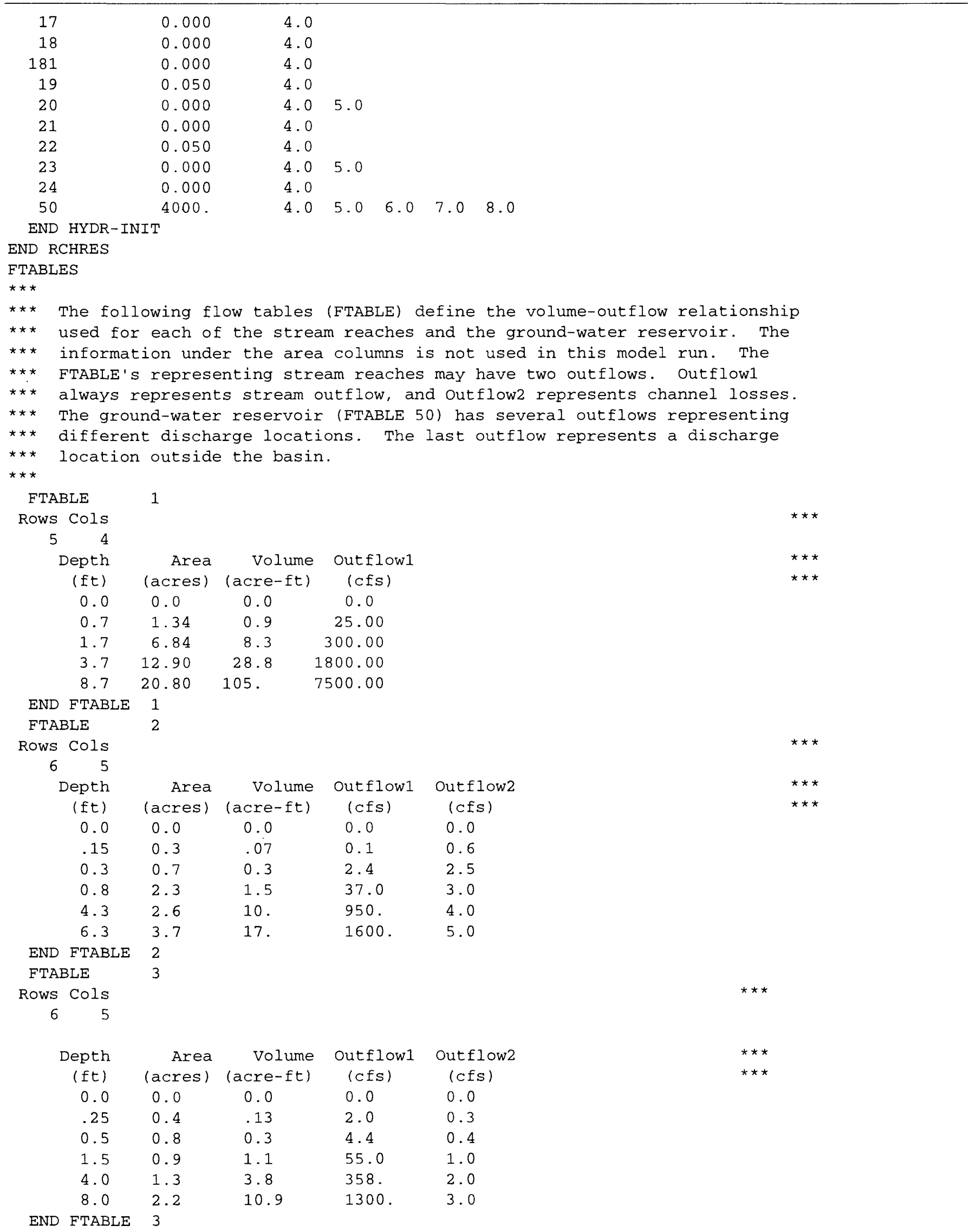


Table 15.--Input sequence of the Clear-Clarks Basin model used to run Hydrological Simulation Program-FORTRAN (HSPF)--Cont.

\begin{tabular}{|c|c|c|c|c|c|c|}
\hline FTABLE & \multicolumn{4}{|l|}{4} & \multirow{2}{*}{\multicolumn{2}{|c|}{$\star \star \star *$}} \\
\hline Rows Cols & & & & & & \\
\hline \multicolumn{7}{|l|}{$5 \quad 4$} \\
\hline Depth & Area & Volume & outflow1 & & & $\star \star \star$ \\
\hline$(f t)$ & (acres) & $(\operatorname{acre}-f t)$ & $(c f s)$ & & & $\star \star *$ \\
\hline 0.0 & 0.0 & 0.0 & 0.0 & & & \\
\hline 0.8 & 1.2 & 0.1 & 0.24 & & & \\
\hline 1.8 & 1.5 & 1.7 & 23.0 & & & \\
\hline 3.8 & 5.3 & 6.9 & 94.0 & & & \\
\hline 6.8 & 32.2 & 36.9 & 390. & & & \\
\hline END FTABLE & 4 & & & & & \\
\hline FTABLE & 5 & & & & & \\
\hline Rows Cols & & & & & & $\star \star \star$ \\
\hline \multicolumn{7}{|l|}{$6 \quad 4$} \\
\hline Depth & Area & Volume & Outflow1 & & & $\star \star \star$ \\
\hline$(f t)$ & (acres) & (acres-ft) & $(c f s)$ & & & $\star \star *$ \\
\hline 0.0 & 0.0 & 0.0 & 0.0 & & & \\
\hline 0.8 & 1.99 & 1.0 & 1.4 & & & \\
\hline 1.8 & 2.88 & 3.5 & 26.0 & & & \\
\hline 4.3 & 4.17 & 11.3 & 160. & & & \\
\hline 4.8 & 6.66 & 13.8 & 170 . & & & \\
\hline 5.8 & 19.9 & 28.9 & 275 & & & \\
\hline END FTABLE & 5 & & & & & \\
\hline FTABLE & 6 & & & & & \\
\hline Rows Cols & & & & & & $\star \star \star$ \\
\hline \multicolumn{7}{|l|}{54} \\
\hline Depth & Area & Volume & Outflow1 & & & $\star \star \star$ \\
\hline$(f t)$ & (acres) & (acre-ft) & (cfs) & & & $\star \star \star$ \\
\hline 0.0 & 0.0 & 0.0 & 0.0 & & & \\
\hline 1.0 & 0.2 & 0.09 & 5.20 & & & \\
\hline 2.0 & 0.9 & 0.60 & 43.0 & & & \\
\hline 5.0 & 1.7 & 4.4 & 780.0 & & & \\
\hline 7.0 & 2.2 & 8.8 & 1900.0 & & & \\
\hline END FTABLE & 6 & & & & & \\
\hline FTABLE & 7 & & & & & \\
\hline \multicolumn{7}{|l|}{ Rows Cols } \\
\hline \multicolumn{7}{|l|}{$5 \quad 5$} \\
\hline Depth & Area & Volume & outflow1 & Outflow2 & & $\star \star \star$ \\
\hline$(f t)$ & (acres) & $(\operatorname{acre}-\mathrm{ft})$ & $(c f s)$ & $(c f s)$ & & $\star \star \star$ \\
\hline 0.0 & 0.0 & 0.0 & 0.0 & 0.0 & & \\
\hline 0.3 & 1.0 & 0.1 & 1.0 & 1.7 & & \\
\hline 1.2 & 2.4 & 2.8 & 180.0 & 5.0 & & \\
\hline 2.2 & 6.7 & 7.6 & 350.0 & 7.0 & & \\
\hline 5.2 & 7.6 & 29.4 & 3000.0 & 10. & & \\
\hline END FTABLE & 7 & & & & & \\
\hline FTABLE & 8 & & & & & \\
\hline Rows Cols & & & & & $\star \star \star$ & \\
\hline \multicolumn{7}{|l|}{$5 \quad 5$} \\
\hline Depth & Area & Volume & Outflow1 & outf1ow2 & $\star \star \star$ & \\
\hline$(f t)$ & (acres) & (acre-ft) & $(c f s)$ & $(c f s)$ & $\star \star \star$ & \\
\hline 0.0 & 0.0 & 0.0 & 0.0 & 0.0 & & \\
\hline 0.3 & 2.0 & 0.25 & 0.0 & 2.1 & & \\
\hline 0.6 & 2.5 & 1.1 & 10.0 & 13. & & \\
\hline 1.0 & 14.3 & 12.0 & 300.0 & 18. & & \\
\hline 4.4 & 34.7 & 105.0 & 2000.0 & 20 & & \\
\hline END FTABLE & 8 & & & & & \\
\hline FTABLE & 9 & & & & & \\
\hline Rows Cols & & & & & & \\
\hline
\end{tabular}


Table 15.--Input sequence of the Clear-Clarks Basin model used to run Hydrological Simulation Program-FORTRAN (HSPF)--Cont.

\begin{tabular}{|c|c|c|c|c|c|}
\hline 64 & & & & & \\
\hline Depth & Area & Volume & \multirow{2}{*}{\multicolumn{2}{|c|}{$\begin{array}{l}\text { Outflow1 } \\
\text { (cfs) }\end{array}$}} & $\star \star \star$ \\
\hline$(f t)$ & (acres) & $($ acre-ft) & & & $\star \star \star$ \\
\hline 0.0 & 0.0 & 0.0 & \multicolumn{2}{|l|}{0.0} & \\
\hline 0.8 & 1.0 & 1.0 & \multicolumn{2}{|l|}{0.3} & \\
\hline 1.0 & 1.7 & 1.5 & \multicolumn{2}{|l|}{5.5} & \\
\hline 4.0 & 1.8 & 3.5 & \multicolumn{2}{|l|}{50} & \\
\hline 5.0 & 4.0 & 5.0 & \multicolumn{2}{|l|}{70} & \\
\hline 6.0 & 6.0 & 10. & \multicolumn{2}{|l|}{120.} & \\
\hline \multicolumn{6}{|c|}{ END FTABLE 9} \\
\hline FTABLE & 10 & & & & \\
\hline \multirow{2}{*}{\multicolumn{5}{|c|}{$\begin{array}{rr}\text { Rows } & \text { Cols } \\
6 & 5\end{array}$}} & $\star \star \star$ \\
\hline & & & & & \\
\hline Depth & Area & Volume & \multirow{2}{*}{$\begin{array}{l}\text { Outflow1 } \\
\text { (cfs) }\end{array}$} & \multirow{2}{*}{$\begin{array}{l}\text { Outflow2 } \\
\text { (cfs) }\end{array}$} & \multirow{2}{*}{$\begin{array}{l}\star \star \star \\
\star \star \star\end{array}$} \\
\hline$(f t)$ & (acres) & $(\operatorname{acres}-f t)$ & & & \\
\hline 0.0 & 0.0 & 0.0 & 0.0 & 0.0 & \\
\hline 0.2 & 0.1 & 0.02 & 0.0 & 4.0 & \\
\hline 1.2 & 0.5 & 0.3 & 10 & 10. & \\
\hline 1.7 & 1.2 & 0.8 & 24.0 & 14. & \\
\hline 3.7 & 1.9 & 3.1 & 250 & 30. & \\
\hline 6.7 & 3.2 & 11.7 & 600 & 40 & \\
\hline \multicolumn{6}{|c|}{ END FTABLE 10} \\
\hline FTABLE & 11 & & & & \\
\hline \multicolumn{5}{|l|}{ Rows Cols } & $\star \star \star$ \\
\hline $6 \quad 5$ & & & & & \\
\hline Depth & Area & Volume & Outflow1 & Outflow2 & $\star * *$ \\
\hline$(f t)$ & (acres) & (acres-ft) & (cfs) & (cfs) & $\star \star \star$ \\
\hline 0.0 & 0.0 & 0.0 & 0.0 & 0.0 & \\
\hline 0.2 & 0.4 & 0.4 & 0.1 & 0.5 & \\
\hline 0.4 & 0.8 & 1.0 & 0.8 & 2.2 & \\
\hline 2.9 & 1.3 & 4.0 & 38. & 10. & \\
\hline 3.9 & 16.9 & 15. & 60 & 30. & \\
\hline 7.4 & 34.9 & 120. & 240 & 50. & \\
\hline END FTABLE & 11 & & & & \\
\hline FTABLE & 12 & & & & \\
\hline Rows Cols & & & & & $\star \star \star$ \\
\hline 64 & & & & & \\
\hline Depth & Area & Volume & Outflow1 & & $\star \star \star$ \\
\hline$(f t)$ & (acres) & $(\operatorname{acres}-f t)$ & (cfs) & & $\star \star \star$ \\
\hline 0.0 & 0.0 & 0.0 & 0.0 & & \\
\hline 0.3 & 0.7 & 2.5 & 0.8 & & \\
\hline 1.3 & 1.0 & 4.0 & 7.0 & & \\
\hline 2.8 & 1.5 & 8.0 & 30.0 & & \\
\hline 3.8 & 14.7 & 15. & 40.0 & & \\
\hline 5.8 & 26.8 & 80 . & 570 & & \\
\hline END FTABLE & 12 & & & & \\
\hline FTABLE & 13 & & & & \\
\hline Rows Cols & & & & & $\star \star \star$ \\
\hline 64 & & & & & \\
\hline Depth & Area & Volume & outflow1 & & $* * *$ \\
\hline$(f t)$ & (acres) & $($ acres-ft) & (cfs) & & $\star \star \star$ \\
\hline 0.0 & 0.0 & 0.0 & 0.0 & & \\
\hline 0.2 & 0.4 & 1.0 & 0.5 & & \\
\hline 0.3 & 0.7 & 5.0 & 1.0 & & \\
\hline 1.0 & 1.1 & 10 . & 2.5 & & \\
\hline 1.8 & 7.6 & 18. & 15. & & \\
\hline 2.8 & 15.2 & 40 & 80. & & \\
\hline END FTABLE & 13 & & & & \\
\hline
\end{tabular}


Table 15.--Input sequence of the Clear-Clarks Basin model used to run Hydrological Simulation Program-FORTRAN(HSPF)--Cont.

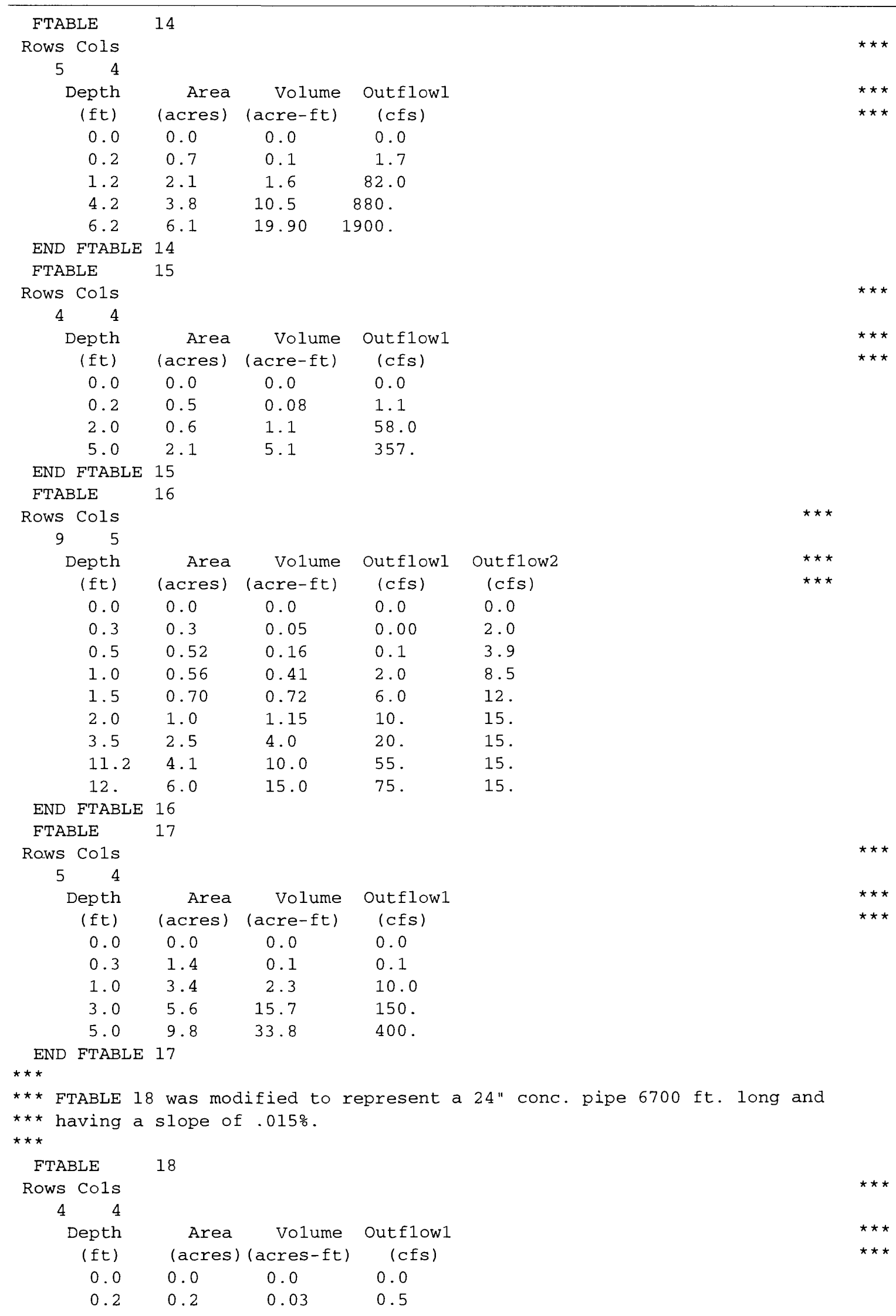


Table 15.--Input sequence of the Clear-Clarks Basin model used to run Hydrological Simulation Program-FORTRAN (HSPF)--Cont.

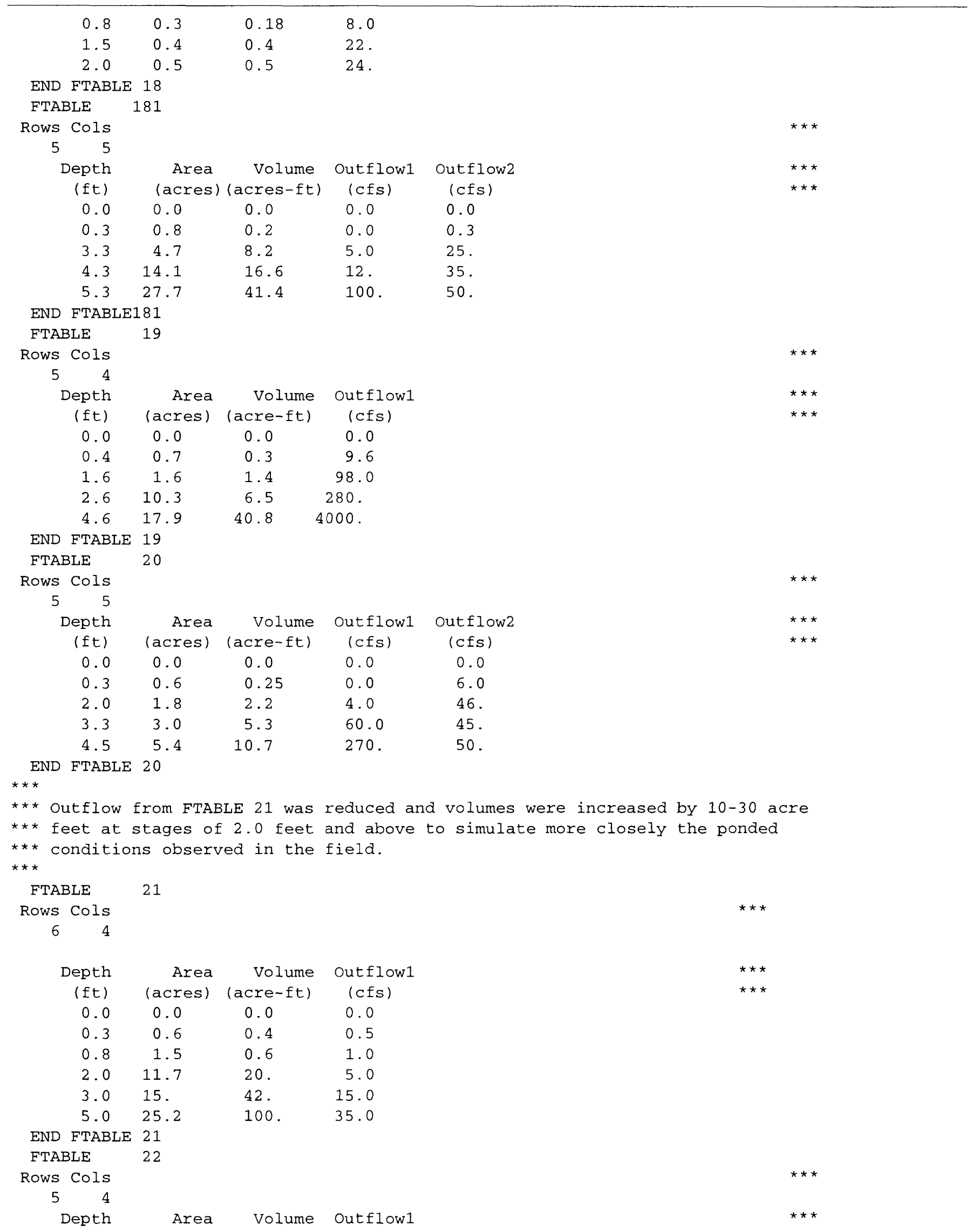


Table 15.--Input sequence of the Clear-Clarks Basin model used to run Hydrological Simulation Program-FORTRAN (HSPF)--Cont.

END FTABLE 22

$\begin{array}{cccc}\text { (ft) } & \text { (acres) } & \text { (acre-ft) } & \text { (cfs) } \\ 0.0 & 0.0 & 0.0 & 0.0 \\ 0.3 & 0.7 & 0.27 & 10.0 \\ 1.0 & 1.6 & 1.0 & 50.0 \\ 1.5 & 5.5 & 3.0 & 100 . \\ 2.0 & 7.6 & 7.1 & 400 . \\ 4.7 & 9.1 & 31.3 & 4000 . \\ \text { FTABLE } & 22 & & \end{array}$

FTABLE 23

Rows Cols

$5 \quad 5$

Depth

(ft)

Area

Volume

Outflow1 Outflow2

0.0

(acres) (acre-ft)

(cfs)

(cfs)

0.3

0.0

0.0

0.0

0.0

1.5

0.5

0.08

0.0

5.0

2.0

1.6

1.1

1.5

22 .

$4.0 \quad 12.2$

2. 9

20.

26.

END FTABLE 23

21.3700 .

30 .

FTABLE 24

Rows Cols

7

Depth

(ft)

$\begin{array}{rrr}\text { Area } & \text { Volume } & \text { Outflow1 } \\ \text { (acres) (acre-ft) } & \text { (cfs) }\end{array}$

$0.0 \quad 0.0$

0.0

0.0

$0.7 \quad 1.2$

0.3

0.002

$3.0 \quad 2.7$

5.0

0.1

3. 528.8

25.0

0.3

0.6

$\begin{array}{llll}5.7 & 59.8 & 100.0 & 3.0\end{array}$

$\begin{array}{llll}6.7 & 80.0 & 200.0 & 10.0\end{array}$

END FTABLE 24

$\star \star \star$

$\star \star \star$ FTABLE 50 represents a ground-water reservoir.

$\star * *$ The size of the reservoir was estimated from the size of the contributing

$\star \star \star$ area (12250 acres) and the range of stage of representative wells, which is

$\star * *$ about 5 and 13 feet (wells 19/3-2Q1 and 20/3-34E1, Walters and Kimmel, 1968

$\star \star *$ pp 55-56.). This range in stage should be about the range in stage the

*** ground-water reservoir experiences during the water year. The specific

$\star \star \star$ yield was estimated at 0.16 (sand and gravel aquifer) and is multiplied

$\star * *$ by the product of the depth and area to estimate the volume. Outflows

$\star \star \star$ are determined from baseflow measurements and calibration.

$\star \star \star$

FTABLE 50

Rows Cols

68

$\star \star \star$ Depth

$\star \star \star \quad(f t)$

0.0

Area Volume Outflow1

Outflow2

Outflow3

Outflow 4

1.0

(acres) (acres-ft)

(cfs)

(cfs)

(cfs)

(cfs)

(cfs)

2.0

2000 .

0.2

0.1

0.0

0.0

12250 .

4000 .

0.45

0.2

7.2

0.7

0.0

$3.0 \quad 12250$.

6000.

0.6

0.4

8.2

1.5

0.1

$4.6 \quad 12250$.

9000 .

0.8

0.6

8.8

2. 2

0.3

$7.6 \quad 12250$.

15000 .

2. 0

0.8

9.8

3.3

0.5

$12.2 \quad 12250$.

24000 .

4.0

3.0

5.0

0.7

END FTABLE 50

20 .

10 .

2.0 
Table 15.--Input sequence of the Clear-Clarks Basin model used to run Hydrological Simulation Program-FORTRAN (HSPF)--Cont.

*** Outflow1 discharges to Diru Creek, Outflow2 discharges to W.F.Clarks Creek,

*** Outflow3 discharges to Clear Creek, Outflow4 discharges to Swan Creek, and

*** Outflow5 represents discharge to Canyon Creek or out of the study basin.

$\star \star \star$

END FTABLES

DISPLY

$\star \star \star$

$\star \star \star$ This block is for displaying time series outputs from the model.

$\star \star \star$

DISPLY - INFO1

$\#$ thru\# $* \star \star<$

$\star \star \star$

$\star \star \star$

1

2

3

4

5

6

7

8

9

10

11

12

13

14

15

END DISPLY-INFO1

END DISPLY
$<-$ short-span $->$

<---disply---> <annual summary ->

TRAN PIVL DIG1 FIL1 PYR DIG2 FIL2 YRND

$\begin{array}{llllllll}\mathrm{MAX} & 0 & 2 & 6 & 1 & 2 & 6 & 9\end{array}$

$\begin{array}{llllllll}\mathrm{MAX} & 0 & 2 & 6 & 1 & 2 & 6 & 9\end{array}$

$\begin{array}{llllllll}\operatorname{MAX} & 0 & 2 & 6 & 1 & 2 & 6 & 9\end{array}$

$\begin{array}{llllllll}\text { MAX } & 0 & 2 & 6 & 1 & 2 & 6 & 9\end{array}$

$\begin{array}{llllllll}\operatorname{MAX} & 0 & 2 & 6 & 1 & 2 & 6 & 9\end{array}$

$\begin{array}{llllllll}\operatorname{MAX} & 0 & 2 & 6 & 1 & 2 & 6 & 9\end{array}$

$\begin{array}{llllllll}\text { MAX } & 0 & 2 & 6 & 1 & 2 & 6 & 9\end{array}$

$\begin{array}{llllllll}\operatorname{MAX} & 0 & 2 & 6 & 1 & 2 & 6 & 9\end{array}$

$\begin{array}{llllllll}\operatorname{MAX} & 0 & 2 & 6 & 1 & 2 & 6 & 9\end{array}$

$\begin{array}{llllllll}\operatorname{MAX} & 0 & 2 & 6 & 1 & 2 & 6 & 9\end{array}$

$\begin{array}{llllllll}\operatorname{MAX} & 0 & 2 & 6 & 1 & 2 & 6 & 9\end{array}$

$\begin{array}{llllllll}\text { SUM } & 0 & 2 & 6 & 1 & 2 & 6 & 9\end{array}$

$\begin{array}{llllllll}\text { SUM } & 0 & 2 & 6 & 1 & 2 & 6 & 9\end{array}$

$\begin{array}{llllllll}\text { SUM } & 0 & 2 & 6 & 1 & 2 & 6 & 9\end{array}$

$\begin{array}{llllllll}\text { SUM } & 0 & 2 & 6 & 1 & 2 & 6 & 9\end{array}$

END RUN 
Table 16.--Input sequence of the Clover Creek Basin model used to run Hydrological Simulation Program-FORTRAN (HSPF)

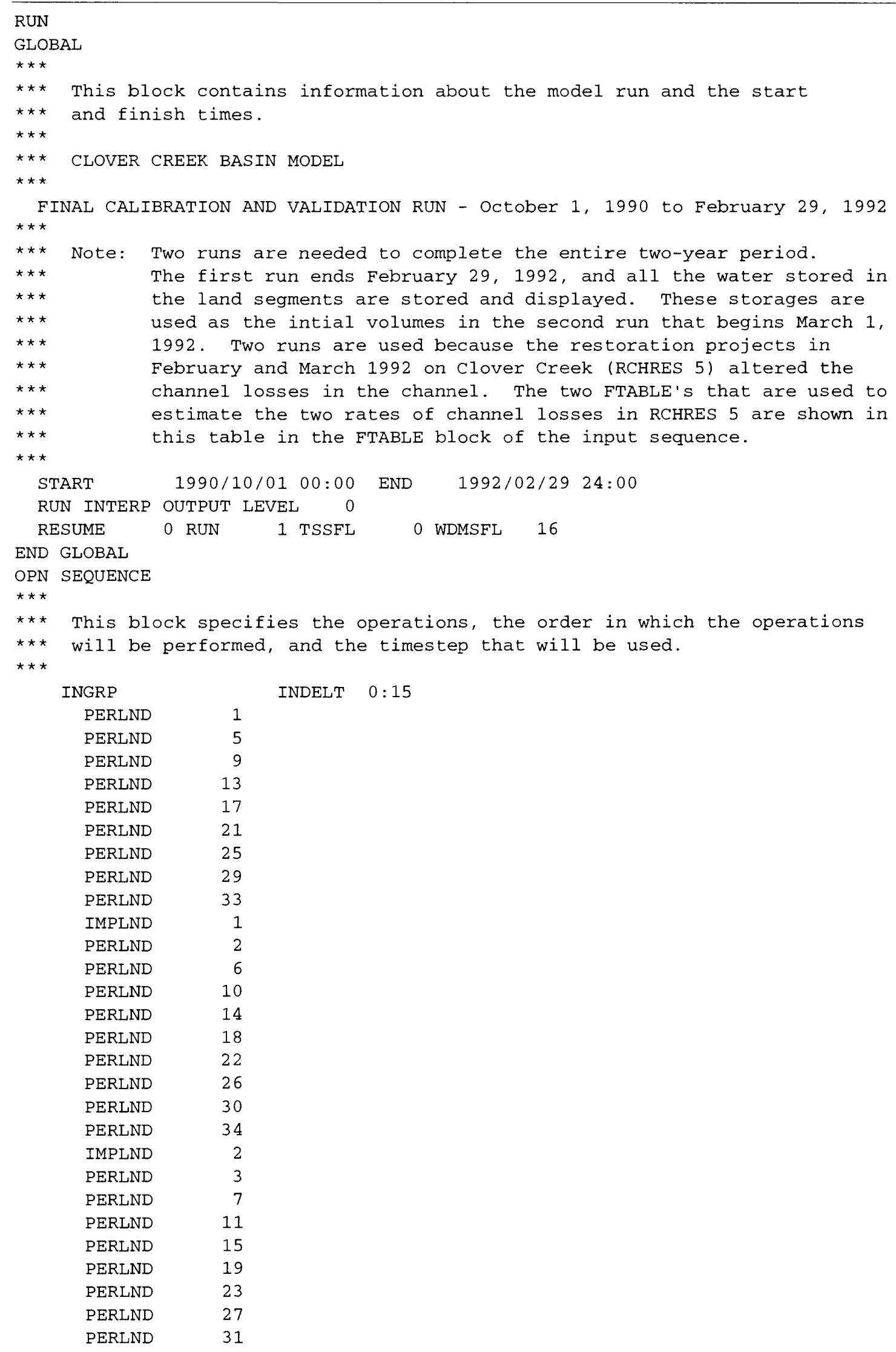


Table 16.--Input sequence of the Clover Creek Basin model used to run Hydrological Simulation Program-FORTRAN (HSPF)--Cont.

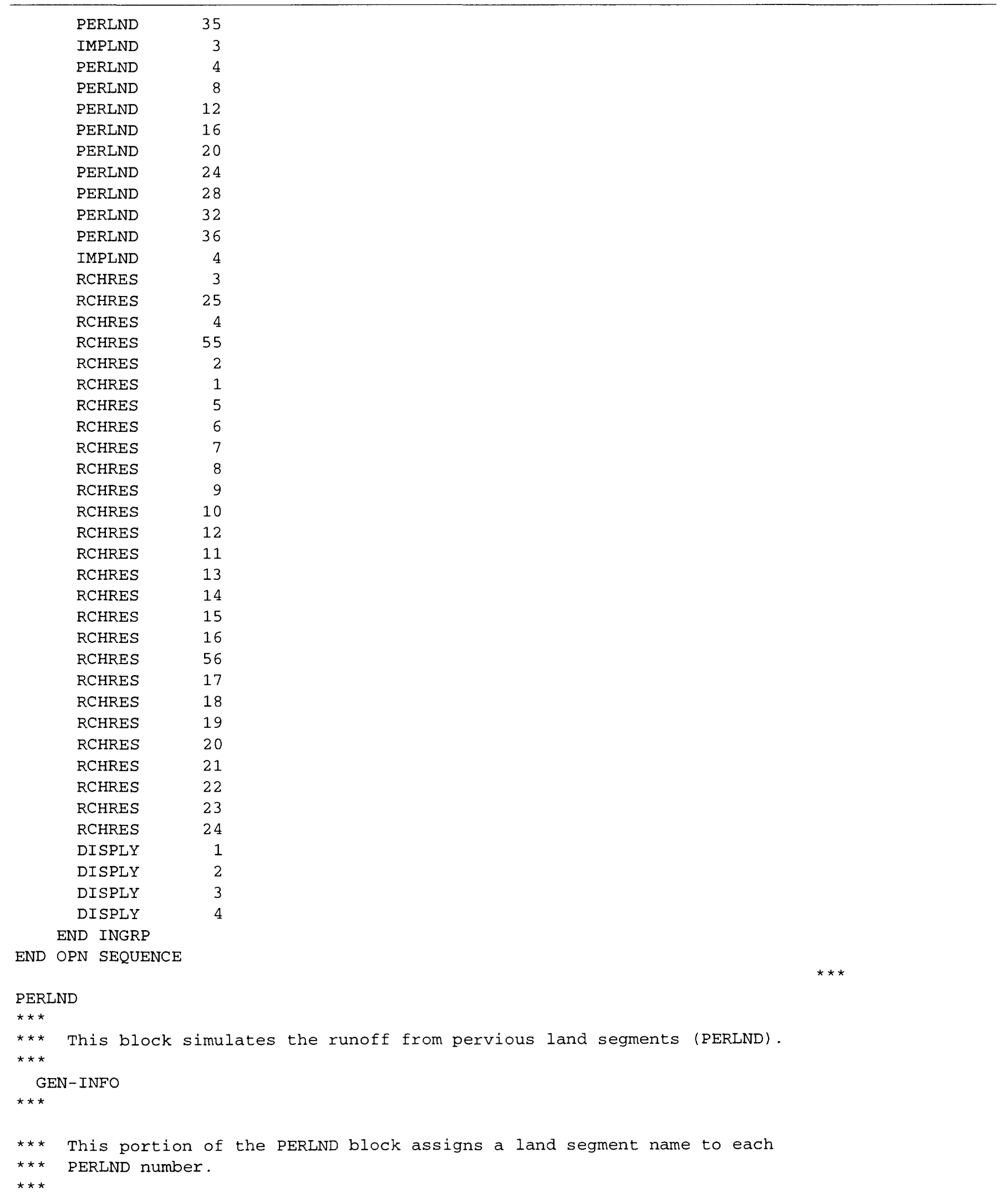

\begin{tabular}{|c|c|}
\hline PERLND & 35 \\
\hline IMPLND & 3 \\
\hline PERLND & 4 \\
\hline PERLND & 8 \\
\hline PERLND & 12 \\
\hline PERLND & 16 \\
\hline PERLND & 20 \\
\hline PERLND & 24 \\
\hline PERLND & 28 \\
\hline PERLND & 32 \\
\hline PERLND & 36 \\
\hline IMPLND & 4 \\
\hline RCHRES & 3 \\
\hline RCHRES & 25 \\
\hline RCHRES & 4 \\
\hline RCHRES & 55 \\
\hline RCHRES & 2 \\
\hline RCHRES & 1 \\
\hline RCHRES & 5 \\
\hline RCHRES & 6 \\
\hline RCHRES & 7 \\
\hline RCHRES & 8 \\
\hline RCHRES & 9 \\
\hline RCHRES & 10 \\
\hline RCHRES & 12 \\
\hline RCHRES & 11 \\
\hline RCHRES & 13 \\
\hline RCHRES & 14 \\
\hline RCHRES & 15 \\
\hline RCHRES & 16 \\
\hline RCHRES & 56 \\
\hline RCHRES & 17 \\
\hline RCHRES & 18 \\
\hline RCHRES & 19 \\
\hline RCHRES & 20 \\
\hline RCHRES & 21 \\
\hline RCHRES & 22 \\
\hline RCHRES & 23 \\
\hline RCHRES & 24 \\
\hline DISPLY & 1 \\
\hline DISPLY & 2 \\
\hline DISPLY & \\
\hline DISPLY & 4 \\
\hline
\end{tabular}

END INGRP

PERLND

$\star \star *$ This block simulates the runoff from pervious land segments (PERLND).

GEN-INFO

** This portion of the PERLND block assigns a land segment name to each

$\star \star \star$ PERLND number. 
Table 16.--Input sequence of the Clover Creek Basin model used to run Hydrological Simulation Program-FORTRAN (HSPF)--Cont.

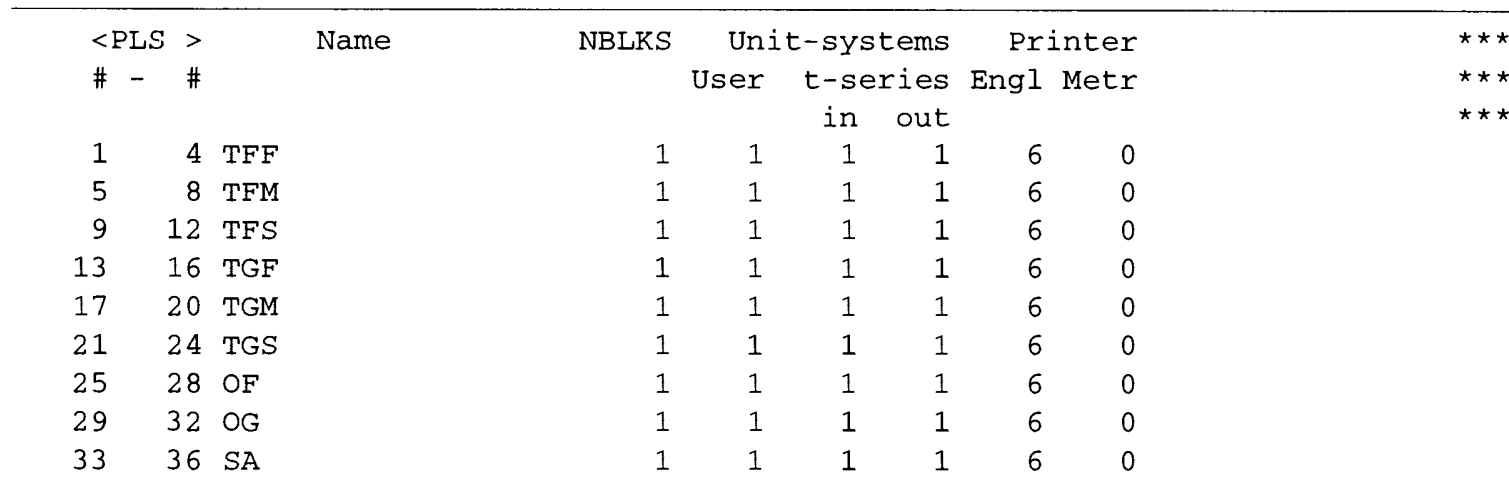

END GEN-INFO

ACTIVITY

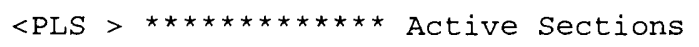

\# - \# ATMP SNOW PWAT SED PST PWG PQAL MSTL PEST NITR PHOS TRAC

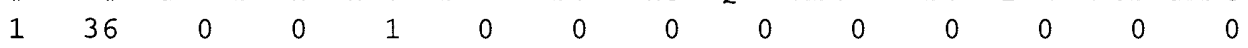

END ACTIVITY

$\star \star \star *$

$\star \star \star$ The print-flags are set to print the output from the PERLND calulations

$\star \star *$ at the end of the year which was designated as the end of the month of

$\star \star \star$ February so that the volumes of water in storage can be used as the initial

$\star \star \star$ volumes in the second model run beginning March 1, 1992.

$\star \star \star$

PRINT-INFO

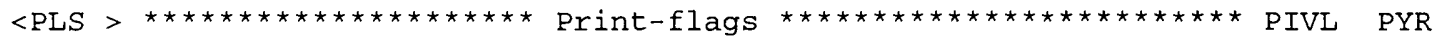

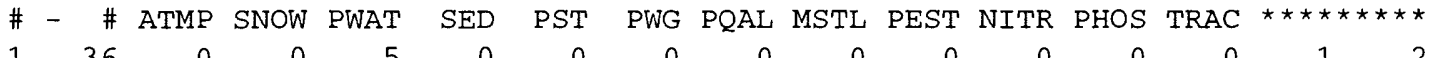

END PRINT-INFO

PWAT-PARM1

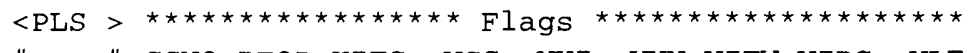

\# - \# CSNO RTOP UZFG VCS VUZ VNN VIFW VIRC VLE

END PWAT-PARM1

$\star \star \star *$

$\star \star \star$ This portion of the PERLND block assigns values to the process-related

$\star \star \star$ parameters.

$\star \star \star$

PWAT-PARM2

$<$ PLS $>\star \star \star$

$\begin{array}{rrrrrrrr}\#-{ }^{*}{ }^{* * *} \text { FOREST } & \text { LZSN } & \text { INFILT } & \text { LSUR } & \text { SLSUR } & \text { KVARY } & \text { AGWRC } \\ 1 & 4 & 6.0000 & 0.0800 & 400.00 & 0.0100 & 0.5000 & 0.8000 \\ 5 & 8 & 6.0000 & 0.0800 & 400.00 & 0.1000 & 0.5000 & 0.8000 \\ 9 & 12 & 6.0000 & 0.0800 & 200.00 & 0.2000 & 0.5000 & 0.8000 \\ 13 & 16 & 6.0000 & 0.0300 & 400.00 & 0.0100 & 0.5000 & 0.8000 \\ 17 & 20 & 6.0000 & 0.0300 & 400.00 & 0.1000 & 0.5000 & 0.8000 \\ 21 & 24 & 6.0000 & 0.0300 & 200.00 & 0.2000 & 0.5000 & 0.8000 \\ 25 & 28 & 5.0000 & 2.0000 & 400.00 & 0.0500 & 0.3000 & 0.9960 \\ 29 & 32 & 5.0000 & 0.8000 & 400.00 & 0.0500 & 0.3000 & 0.9960 \\ 33 & 36 & 5.0000 & 2.0000 & 100.00 & 0.0010 & 0.5000 & 0.8000\end{array}$

END PWAT-PARM2

PWAT-PARM3

\begin{tabular}{|c|c|c|c|c|c|c|c|c|}
\hline \multicolumn{9}{|c|}{$<\operatorname{PLS}>\star \star \star$} \\
\hline$\#-$ & $\# \star \star \star$ & PETMAX & PETMIN & INFEXP & INFILD & DEEPFR & BASETP & AGWETP \\
\hline 1 & 4 & & & 3.5000 & 2.0000 & .25 & 0 & 0.8 \\
\hline 5 & 8 & & & 2.0000 & 2.0000 & .25 & 0 . & 0.8 \\
\hline 9 & 12 & & & 1.5000 & 2.0000 & .25 & 0 . & 0.8 \\
\hline
\end{tabular}


Table 16.--Input sequence of the Clover Creek Basin model used to run Hydrological Simulation Program-FORTRAN (HSPF)--Cont.

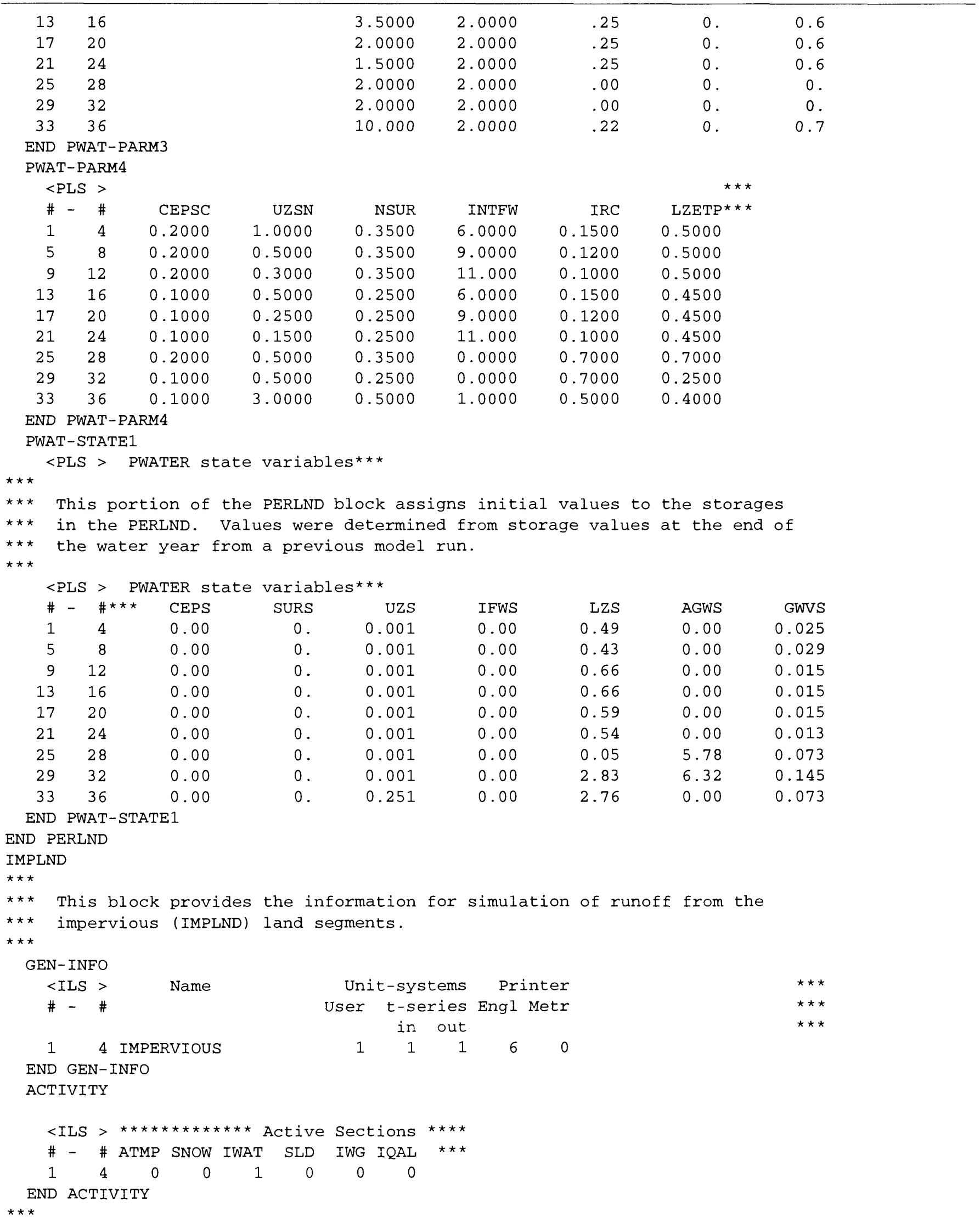


Table 16.--Input sequence of the Clover Creek Basin model used to run Hydrological Simulation Program-FORTRAN (HSPF)--Cont.

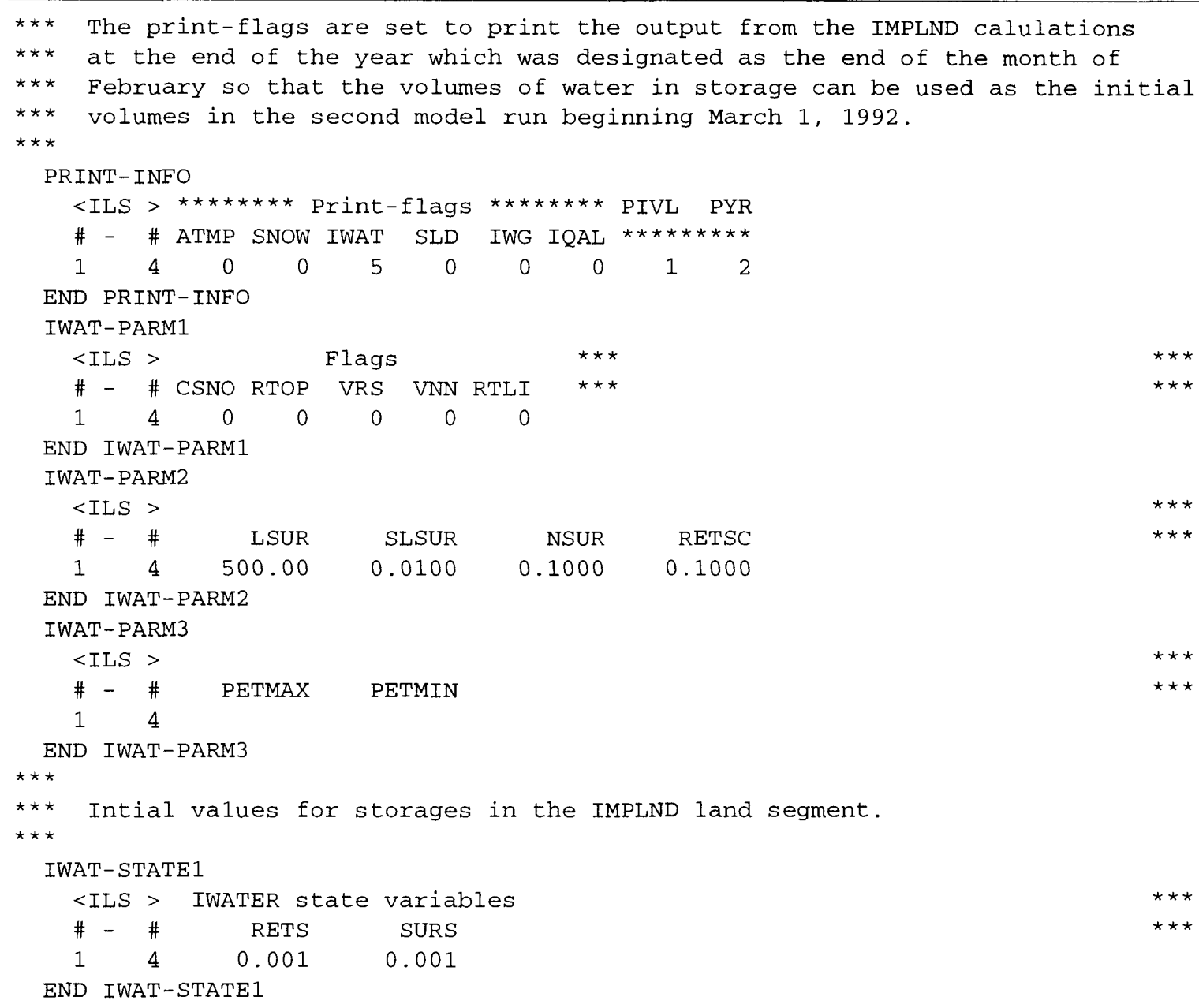


Table 16.--Input sequence of the Clover Creek Basin model used to run Hydrological Simulation Program-FORTRAN (HSPF)--Cont.

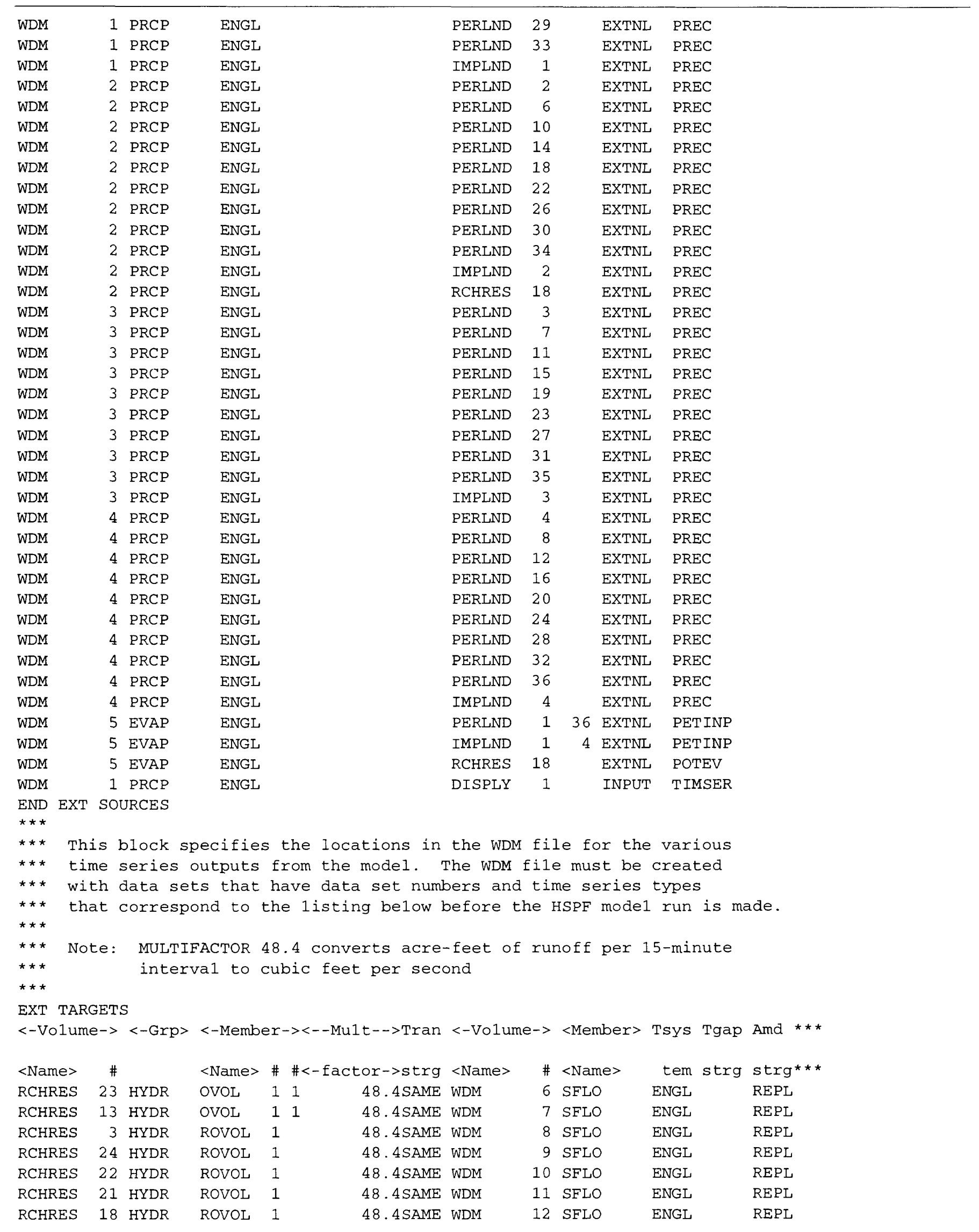


Table 16.--Input sequence of the Clover Creek Basin model used to run Hydrological Simulation Program-FORTRAN (HSPF)--Cont.

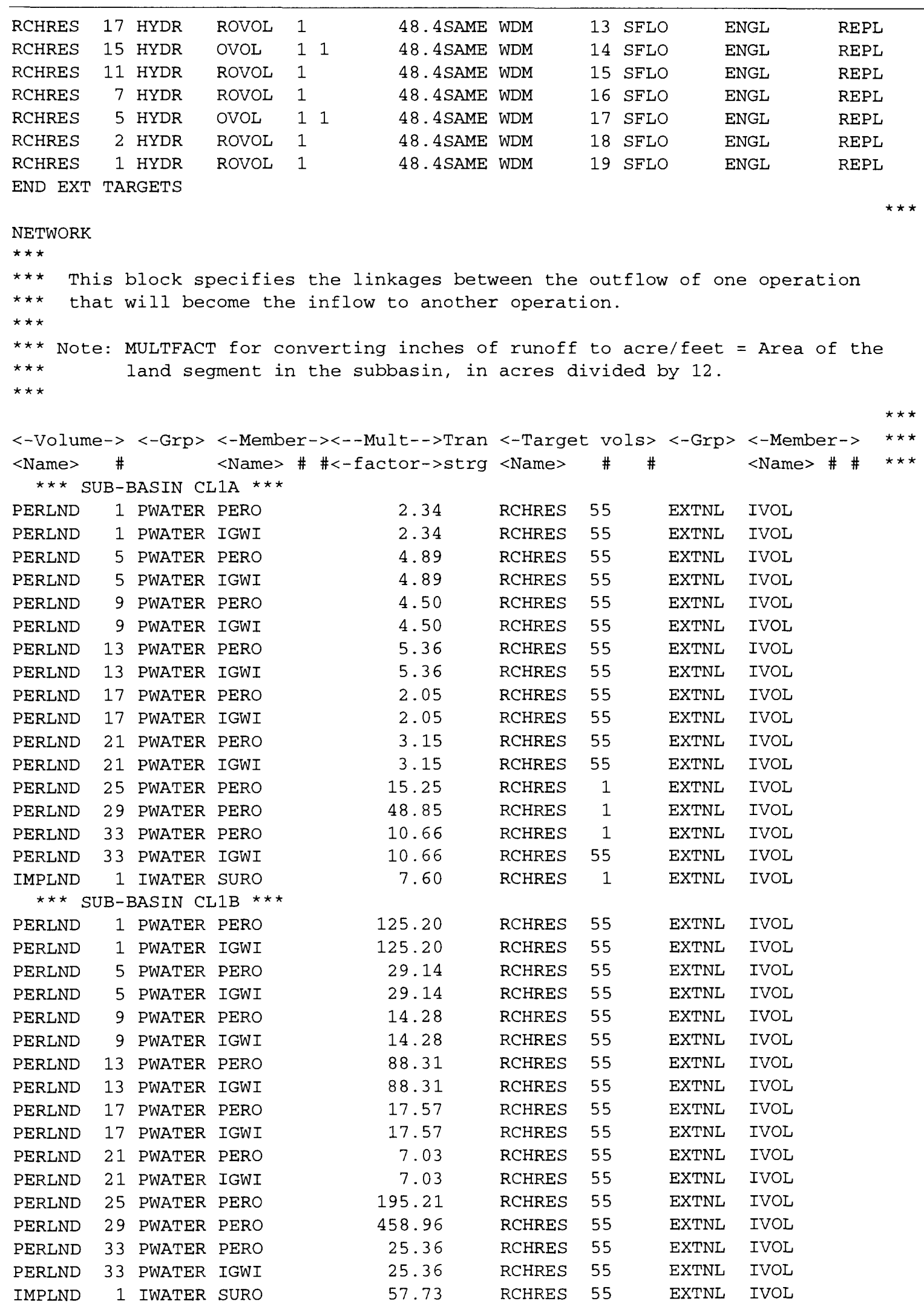


Table 16.--Input sequence of the Clover Creek Basin model used to run Hydrological Simulation Program-FORTRAN (HSPF)--Cont.

\begin{tabular}{|c|c|c|c|c|c|c|c|}
\hline \multicolumn{8}{|c|}{ 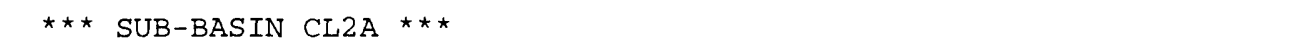 } \\
\hline PERLND & 1 & PWATER PERO & 36.38 & RCHRES & 2 & EXTNL & IVOL \\
\hline PERLND & 1 & PWATER IGWI & 36.38 & RCHRES & 55 & EXTNL & IVOL \\
\hline PERLND & 5 & PWATER PERO & 0.21 & RCHRES & 2 & EXTNL & IVOL \\
\hline PERLND & 5 & PWATER IGWI & 0.21 & RCHRES & 55 & EXTNL & IVOL \\
\hline PERLND & 9 & PWATER PERO & 6.62 & RCHRES & 2 & EXTNL & IVOL \\
\hline PERLND & 9 & PWATER IGWI & 6.62 & RCHRES & 55 & EXTNL & IVOL \\
\hline PERLND & 13 & PWATER PERO & 27.74 & RCHRES & 2 & EXTNL & IVOL \\
\hline PERLND & 13 & PWATER IGWI & 27.74 & RCHRES & 55 & EXTNL & IVOL \\
\hline PERLND & 17 & PWATER PERO & 0.35 & RCHRES & 2 & EXTNL & IVOL \\
\hline PERLND & 17 & PWATER IGWI & 0.35 & RCHRES & 55 & EXTNL & IVOL \\
\hline PERLND & 21 & PWATER PERO & 2.82 & RCHRES & 2 & EXTNL & IVOL \\
\hline PERLND & 21 & PWATER IGWI & 2.82 & RCHRES & 55 & EXTNL & IVOL \\
\hline PERLND & 25 & PWATER PERO & 47.34 & RCHRES & 2 & EXTNL & IVOL \\
\hline PERLND & 29 & PWATER PERO & 67.65 & RCHRES & 2 & EXTNL & IVOL \\
\hline PERLND & 33 & PWATER PERO & 8.57 & RCHRES & 2 & EXTNL & IVOL \\
\hline PERLND & 33 & PWATER IGWI & 8.57 & RCHRES & 55 & EXTNL & IVOL \\
\hline IMPLND & 1 & IWATER SURO & 12.44 & RCHRES & 55 & EXTNL & IVOL \\
\hline \multicolumn{8}{|c|}{ 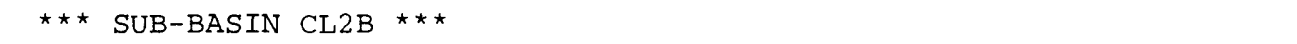 } \\
\hline PERLND & 1 & PWATER PERO & 29.30 & RCHRES & 55 & EXTNL & IVOL \\
\hline PERLND & 1 & PWATER IGWI & 29.30 & RCHRES & 55 & EXTNL & IVOL \\
\hline PERLND & 5 & PWATER PERO & 1.38 & RCHRES & 55 & EXTNL & IVOL \\
\hline PERLND & 5 & PWATER IGWI & 1.38 & RCHRES & 55 & EXTNL & IVOL \\
\hline PERLND & 9 & PWATER PERO & 3.54 & RCHRES & 55 & EXTNL & IVOL \\
\hline PERLND & 9 & PWATER IGWI & 3.54 & RCHRES & 55 & EXTNL & IVOL \\
\hline PERLND & 13 & PWATER PERO & 18.17 & RCHRES & 55 & EXTNL & IVOL \\
\hline PERLND & 13 & PWATER IGWI & 18.17 & RCHRES & 55 & EXTNL & IVOL \\
\hline PERLND & 17 & PWATER PERO & 0.68 & RCHRES & 55 & EXTNL & IVOL \\
\hline PERLND & 17 & PWATER IGWI & 0.68 & RCHRES & 55 & EXTNL & IVOL \\
\hline PERLND & 21 & PWATER PERO & 0.82 & RCHRES & 55 & EXTNL & IVOL \\
\hline PERLND & 21 & PWATER IGWI & 0.82 & RCHRES & 55 & EXTNL & IVOL \\
\hline PERLND & 25 & PWATER PERO & 93.62 & RCHRES & 55 & EXTNL & IVOL \\
\hline PERLND & 29 & PWATER PERO & 71.76 & RCHRES & 55 & EXTNL & IVOL \\
\hline PERLND & 33 & PWATER PERO & 6.98 & RCHRES & 55 & EXTNL & IVOL \\
\hline PERLND & 33 & PWATER IGWI & 6.98 & RCHRES & 55 & EXTNL & IVOL \\
\hline IMPLND & 1 & IWATER SURO & 8.78 & RCHRES & 55 & EXTNL & IVOL \\
\hline \multicolumn{8}{|c|}{ 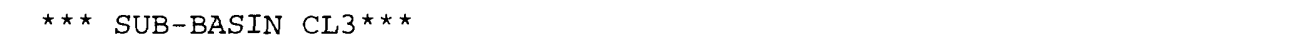 } \\
\hline PERLND & 1 & PWATER PERO & 21.74 & RCHRES & 3 & EXTNL & IVOL \\
\hline PERLND & 1 & PWATER IGWI & 21.74 & RCHRES & 55 & EXTNL & IVOL \\
\hline PERLND & 9 & PWATER PERO & 0.34 & RCHRES & 3 & EXTNL & IVOL \\
\hline PERLND & 9 & PWATER IGWI & 0.34 & RCHRES & 55 & EXTNL & IVOL \\
\hline PERLND & 13 & PWATER PERO & 72.60 & RCHRES & 3 & EXTNL & IVOL \\
\hline PERLND & 13 & PWATER IGWI & 72.60 & RCHRES & 55 & EXTNL & IVOL \\
\hline PERLND & 21 & PWATER PERO & 2.67 & RCHRES & 3 & EXTNL & IVOL \\
\hline PERLND & 21 & PWATER IGWI & 2.67 & RCHRES & 55 & EXTNL & IVOL \\
\hline PERLND & 25 & PWATER PERO & 0.50 & RCHRES & 3 & EXTNL & IVOL \\
\hline PERLND & 29 & PWATER PERO & 11.62 & RCHRES & 3 & EXTNL & IVOL \\
\hline PERLND & 33 & PWATER PERO & 7.88 & RCHRES & 3 & EXTNL & IVOL \\
\hline PERLND & 33 & PWATER IGWI & 7.88 & RCHRES & 55 & EXTNL & IVOL \\
\hline IMPLND & 1 & IWATER SURO & 11.02 & RCHRES & 3 & EXTNL & IVOL \\
\hline \multicolumn{8}{|c|}{ 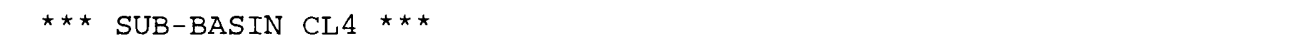 } \\
\hline PERLND & 1 & PWATER PERO & 8.71 & RCHRES & 4 & EXTNL & IVOL \\
\hline PERLND & 1 & PWATER IGWI & 8.71 & RCHRES & 55 & EXTNL & IVOL \\
\hline PERLND & 5 & PWATER PERO & 2.31 & RCHRES & 4 & EXTNL & IVOL \\
\hline PERLND & 5 & PWATER IGWI & 2.31 & RCHRES & 55 & EXTNL & IVOL \\
\hline PERLND & 9 & PWATER PERO & 1.13 & RCHRES & 4 & EXTNL & IVOL \\
\hline PERLND & 9 & PWATER IGWI & 1.13 & RCHRES & 55 & EXTNL & IVOL \\
\hline PERLND & 13 & PWATER PERO & 26.35 & RCHRES & 4 & EXTNL & IVOL \\
\hline
\end{tabular}


Table 16.--Input sequence of the Clover Creek Basin model used to run Hydrological Simulation Program-FORTRAN (HSPF)--Cont.

\begin{tabular}{lrlrlrll}
\hline PERLND & 13 & PWATER IGWI & 26.35 & RCHRES & 55 & EXTNL & IVOL \\
PERLND & 17 & PWATER PERO & 2.58 & RCHRES & 4 & EXTNL & IVOL \\
PERLND & 17 & PWATER IGWI & 2.58 & RCHRES & 55 & EXTNL & IVOL \\
PERLND & 21 & PWATER PERO & 0.12 & RCHRES & 4 & EXTNL & IVOL \\
PERLND & 21 & PWATER IGWI & 0.12 & RCHRES & 55 & EXTNL & IVOL \\
PERLND & 33 & PWATER PERO & 2.11 & RCHRES & 4 & EXTNL & IVOL \\
PERLND & 33 & PWATER IGWI & 2.11 & RCHRES & 55 & EXTNL & IVOL \\
IMPLND & 1 & IWATER SURO & 3.04 & RCHRES & 4 & EXTNL & IVOL
\end{tabular}

$\star \star \star$

$\star \star *$ The SURO from the IMPLND is routed into the groundwater reservoir,

** RCHRES 56, in subbasins that route runoff to using dry wells--CL5,

$\star \star \star$ CL7, CL8, CL9, SP2, SP4, and SP5.

$\star \star \star$

$\star \star \star$ SUB-BASIN CL5 $\star \star \star ~$

PERLND 2 PWATER PERO

PERLND 2 PWATER IGWI

0.03 RCHRES 5

PERLND 6 PWATER PERO

0.03

RCHRES 56

1.31

PERLND 6 PWATER IGWI

1. 31

PERLND 10 PWATER PERO

1.03

PERLND 10 PWATER IGWI

1.03

RCHRES 5

RCHRES 56

PERLND 14 PWATER PERO

0.01

PERLND 14 PWATER IGWI

0.01

PERLND 18 PWATER PERO

0.04

PERLND 18 PWATER IGWI

0.04

PERLND 22 PWATER PERO

0.10

PERLND 22 PWATER IGWI

0.10

PERLND 26 PWATER PERO

10.83

PERLND 30 PWATER PERO

79.44

PERLND 34 PWATER PERO

11.14

PERLND 34 PWATER IGWI

11.14

IMPLND 2 IWATER SURO

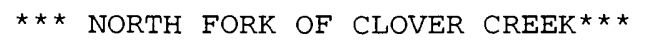

$\star \star \star$ SUB-BASIN NF 1 * $\star \star$

\begin{tabular}{|c|c|c|c|}
\hline PERLND & 3 & PWATER & PERO \\
\hline PERLND & 3 & PWATER & IGWI \\
\hline PERLND & 15 & PWATER & PERO \\
\hline PERLND & 15 & PWATER & IGWI \\
\hline PERLND & 35 & PWATER & PERO \\
\hline PERLND & 35 & PWATER & IGWI \\
\hline IMPLND & 3 & IWATER & SURO \\
\hline$\star \star \star \quad$ SUB & $-B A$ & IN NF2 & 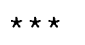 \\
\hline PERLND & 3 & PWATER & PERO \\
\hline PERLND & 3 & PWATER & IGWI \\
\hline PERLND & 7 & PWATER & PERO \\
\hline PERLND & 7 & PWATER & IGWI \\
\hline PERLND & 11 & PWATER & PERO \\
\hline PERLND & 11 & PWATER & IGWI \\
\hline PERLND & 15 & PWATER & PERO \\
\hline PERLND & 15 & PWATER & IGWI \\
\hline PERLND & 19 & PWATER & PERO \\
\hline PERLND & 19 & PWATER & IGWI \\
\hline PERLND & 23 & PWATER & PERO \\
\hline PERLND & 23 & PWATER & IGWI \\
\hline PERLND & 27 & PWATER & PERO \\
\hline PERLND & 31 & PWATER & PERO \\
\hline PERLND & 35 & PWATER & PERO \\
\hline PERLND & 35 & PWATER & IGWI \\
\hline IMPLND & 3 & IWATER & SURO \\
\hline
\end{tabular}

6.24

6.24

25.69

25.69

7.67

7.67

2.18

3.25

3.25

7.28

7.28

1. 512

1.512

44.21

44.21

3.51

3.51

0.61

0.61

0.02

0.03

1.89

1.89

4.78
RCHRES 5

RCHRES 56

RCHRES 5

RCHRES 56

RCHRES 5

RCHRES 56

RCHRES 5

RCHRES 56

RCHRES 5

RCHRES 5

RCHRES 5

RCHRES 56

RCHRES 56

RCHRES

RCHRES 56

RCHRES 6

RCHRES 56

RCHRES 6

RCHRES 56

RCHRES 6

RCHRES 7

RCHRES 56

RCHRES 7

RCHRES 56

RCHRES 7

RCHRES 56

RCHRES 7

RCHRES 56

RCHRES 7

RCHRES 56

RCHRES 7

RCHRES 56

RCHRES 7

RCHRES 7

RCHRES 7

RCHRES 56

RCHRES 7
EXTNL IVOL

EXTNL IVOL

EXTNL IVOL

EXTNL IVOL

EXTNL IVOL

EXTNL IVOL

EXTNL IVOL

EXTNL IVOL

EXTNL IVOL

EXTNL IVOL

EXTNL IVOL

EXTNL IVOL

EXTNL IVOL

EXTNL IVOL

EXTNL IVOL

EXTNL IVOL

EXTNL IVOL

EXTNL IVOL

EXTNL IVOL

EXTNL IVOL

EXTNL IVOL

EXTNL IVOL

EXTNL IVOL

EXTNL IVOL

EXTNL IVOL

EXTNL IVOL

EXTNL IVOL

EXTNL IVOL

EXTNL IVOL

EXTNL IVOL

EXTNL IVOL

EXTNL IVOL

EXTNL IVOL

EXTNL IVOL

EXTNL IVOL

EXTNL IVOL

EXTNL IVOL

EXTNL IVOL

EXTNL IVOL

EXTNL IVOL

EXTNL IVOL 
Table 16.--Input sequence of the Clover Creek Basin model used to run Hydrological Simulation Program-FORTRAN(HSPF)--Cont.

\begin{tabular}{|c|c|c|c|c|c|c|c|c|}
\hline \multicolumn{9}{|c|}{$\star \star \star$ SUB-BASIN NF $3 \star \star \star \star$} \\
\hline PERLND & 3 & PWATER & PERO & 3.01 & RCHRES & 8 & EXTNL & IVOL \\
\hline PERLND & 3 & PWATER & IGWI & 3.01 & RCHRES & 56 & EXTNL & IVOL \\
\hline PERLND & 7 & PWATER & PERO & 1.22 & RCHRES & 8 & EXTNL & IVOL \\
\hline PERLND & 7 & PWATER & IGWI & 1.22 & RCHRES & 56 & EXTNL & IVOL \\
\hline PERLND & 15 & PWATER & PERO & 52.74 & RCHRES & 8 & EXTNL & IVOL \\
\hline PERLND & 15 & PWATER & IGWI & 52.74 & RCHRES & 56 & EXTNL & IVOL \\
\hline PERLND & 19 & PWATER & PERO & 0.45 & RCHRES & 8 & EXTNL & IVOL \\
\hline PERLND & 19 & PWATER & IGWI & 0.45 & RCHRES & 56 & EXTNL & IVOL \\
\hline PERLND & 35 & PWATER. & PERO & 7.03 & RCHRES & 8 & EXTNL & IVOL \\
\hline PERLND & 35 & PWATER & IGWI & 7.03 & RCHRES & 56 & EXTNL & IVOL \\
\hline IMPLND & 3 & IWATER & SURO & 11.98 & RCHRES & 8 & EXTNL & IVOL \\
\hline \multicolumn{9}{|c|}{$\star \star \star$ SUB-BASIN NF $4 \quad \star \star \star$} \\
\hline PERLND & 3 & PWATER & PERO & 3.20 & RCHRES & 9 & EXTNL & IVOL \\
\hline PERLND & 3 & PWATER & IGWI & 3.20 & RCHRES & 56 & EXTNL & IVOL \\
\hline PERLND & 15 & PWATER & PERO & 29.70 & RCHRES & 9 & EXTNL & IVOL \\
\hline PERLND & 15 & PWATER & IGWI & 29.70 & RCHRES & 56 & EXTNL & IVOL \\
\hline PERLND & 35 & PWATER & PERO & 1.82 & RCHRES & 9 & EXTNL & IVOL \\
\hline PERLND & 35 & PWATER & IGWI & 1.82 & RCHRES & 56 & EXTNL & IVOL \\
\hline IMPLND & 3 & IWATER & SURO & 11.13 & RCHRES & 9 & EXTNL & IVOL \\
\hline \multicolumn{9}{|c|}{$\star \star \star$ SUB-BASIN NF5 $\star \star \star \star$} \\
\hline PERLND & 3 & PWATER & PERO & 1.47 & RCHRES & 10 & EXTNL & IVOL \\
\hline PERLND & 3 & PWATER & IGWI & 1.47 & RCHRES & 56 & EXTNL & IVOL \\
\hline PERLND & 7 & PWATER & PERO & 1.87 & RCHRES & 10 & EXTNL & IVOL \\
\hline PERLND & 7 & PWATER & IGWI & 1.87 & RCHRES & 56 & EXTNL & IVOL \\
\hline PERLND & 15 & PWATER & PERO & 6.25 & RCHRES & 10 & EXTNL & IVOL \\
\hline PERLND & 15 & PWATER & IGWI & 6.25 & RCHRES & 56 & EXTNL & IVOL \\
\hline PERLND & 19 & PWATER & PERO & 3.27 & RCHRES & 10 & EXTNL & IVOL \\
\hline PERLND & 19 & PWATER & IGWI & 3.27 & RCHRES & 56 & EXTNL & IVOL \\
\hline PERLND & 31 & PWATER & PERO & 0.06 & RCHRES & 10 & EXTNL & IVOL \\
\hline PERLND & 35 & PWATER & PERO & 0.02 & RCHRES & 10 & EXTNL & IVOL \\
\hline PERLND & 35 & PWATER & IGWI & 0.02 & RCHRES & 56 & EXTNL & IVOL \\
\hline IMPLND & 3 & IWATER & SURO & 1.02 & RCHRES & 10 & EXTNL & IVOL \\
\hline \multicolumn{9}{|c|}{ 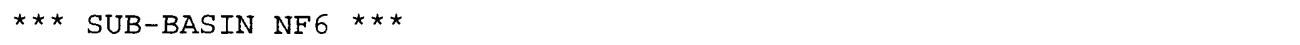 } \\
\hline PERLND & 3 & PWATER & PERO & 9.47 & RCHRES & 11 & EXTNL & IVOL \\
\hline PERLND & 3 & PWATER & IGWI & 9.47 & RCHRES & 56 & EXTNL & IVOL \\
\hline PERLND & 7 & PWATER & PERO & 4.73 & RCHRES & 11 & EXTNL & IVOL \\
\hline PERLND & 7 & PWATER & IGWI & 4.73 & RCHRES & 56 & EXTNL & IVOL \\
\hline PERLND & 11 & PWATER & PERO & 0.10 & RCHRES & 11 & EXTNL & IVOL \\
\hline PERLND & 11 & PWATER & IGWI & 0.10 & RCHRES & 56 & EXTNL & IVOL \\
\hline PERLND & 15 & PWATER & PERO & 26.67 & RCHRES & 11 & EXTNL & IVOL \\
\hline PERLND & 15 & PWATER & IGWI & 26.67 & RCHRES & 56 & EXTNL & IVOL \\
\hline PERLND & 19 & PWATER & PERO & 3.65 & RCHRES & 11 & EXTNL & IVOL \\
\hline PERLND & 19 & PWATER & IGWI & 3.65 & RCHRES & 56 & EXTNL & IVOL \\
\hline PERLND & 27 & PWATER & PERO & 0.81 & RCHRES & 11 & EXTNL & IVOL \\
\hline PERLND & 31 & PWATER & PERO & 0.23 & RCHRES & 11 & EXTNL & IVOL \\
\hline PERLND & 35 & PWATER & PERO & 2.42 & RCHRES & 11 & EXTNL & IVOL \\
\hline PERLND & 35 & PWATER & IGWI & 2.42 & RCHRES & 56 & EXTNL & IVOL \\
\hline IMPLND & 3 & IWATER & SURO & 2.07 & RCHRES & 11 & EXTNL & IVOL \\
\hline \multicolumn{9}{|c|}{$\star \star *$ SUB-BASIN NF7 } \\
\hline PERLND & 3 & PWATER & PERO & 0.70 & RCHRES & 12 & EXTNL & IVOL \\
\hline PERLND & 3 & PWATER & IGWI & 0.70 & RCHRES & 56 & EXTNL & IVOL \\
\hline PERLND & 7 & PWATER & PERO & 3.43 & RCHRES & 12 & EXTNL & IVOL \\
\hline PERLND & 7 & PWATER & IGWI & 3.43 & RCHRES & 56 & EXTNL & IVOL \\
\hline PERLND & 15 & PWATER & PERO & 4.92 & RCHRES & 12 & EXTNL & IVOL \\
\hline PERLND & 15 & PWATER & IGWI & 4.92 & RCHRES & 56 & EXTNL & IVOL \\
\hline PERLND & 19 & PWATER & PERO & 3.33 & RCHRES & 12 & EXTNL & IVOL \\
\hline PERLND & 19 & PWATER & IGWI & 3.33 & RCHRES & 56 & EXTNL & IVOL \\
\hline IMPLND & 3 & IWATER & SURO & 0.74 & RCHRES & 12 & EXTNL & IVOL \\
\hline
\end{tabular}


Table 16.--Input sequence of the Clover Creek Basin model used to run Hydrological Simulation Program-FORTRAN (HSPF)--Cont.

\begin{tabular}{|c|c|c|c|c|c|c|c|c|}
\hline \multicolumn{9}{|c|}{$\star \star \star$ SUB-BASIN NF8 $\star \star \star \star$} \\
\hline PERLND & 14 & PWATER & PERO & 4.46 & RCHRES & 13 & EXTNL & IVOL \\
\hline PERLND & 14 & PWATER & IGWI & 4.46 & RCHRES & 56 & EXTNL & IVOL \\
\hline PERLND & 18 & PWATER & PERO & 0.03 & RCHRES & 13 & EXTNL & IVOL \\
\hline PERLND & 18 & PWATER & IGWI & 0.03 & RCHRES & 56 & EXTNL & IVOL \\
\hline PERLND & 22 & PWATER & PERO & 1.58 & RCHRES & 13 & EXTNL & IVOL \\
\hline PERLND & 22 & PWATER & IGWI & 1.58 & RCHRES & 56 & EXTNL & IVOL \\
\hline PERLND & 26 & PWATER & PERO & 0.01 & RCHRES & 13 & EXTNL & IVOL \\
\hline PERLND & 30 & PWATER & PERO & 10.77 & RCHRES & 13 & EXTNL & IVOL \\
\hline PERLND & 34 & PWATER & PERO & 3.12 & RCHRES & 13 & EXTNL & IVOL \\
\hline PERLND & 34 & PWATER & IGWI & 3.12 & RCHRES & 56 & EXTNL & IVOL \\
\hline IMPLND & 2 & IWATER & SURO & 3.31 & RCHRES & 13 & EXTNL & IVOL \\
\hline \multicolumn{9}{|c|}{$\star \star \star$ SUB-BASIN CL $6 \quad \star \star \star$} \\
\hline PERLND & 2 & PWATER & PERO & 0.01 & RCHRES & 14 & EXTNL & IVOL \\
\hline PERLND & 2 & PWATER & IGWI & 0.01 & RCHRES & 56 & EXTNL & IVOL \\
\hline PERLND & 14 & PWATER & PERO & 12.58 & RCHRES & 14 & EXTNL & IVOL \\
\hline PERLND & 14 & PWATER & IGWI & 12.58 & RCHRES & 56 & EXTNL & IVOL \\
\hline PERLND & 22 & PWATER & PERO & 0.47 & RCHRES & 14 & EXTNL & IVOL \\
\hline PERLND & 22 & PWATER & IGWI & 0.47 & RCHRES & 56 & EXTNL & IVOL \\
\hline PERLND & 30 & PWATER & PERO & 1.19 & RCHRES & 14 & EXTNL & IVOL \\
\hline PERLND & 34 & PWATER & PERO & 1.22 & RCHRES & 14 & EXTNL & IVOL \\
\hline PERLND & 34 & PWATER & IGWI & 1.22 & RCHRES & 56 & EXTNL & IVOL \\
\hline IMPLND & 2 & IWATER & SURO & 2.00 & RCHRES & 14 & EXTNL & IVOL \\
\hline \multicolumn{9}{|c|}{$\star \star \star$ SUB-BASIN CL $7 * \star \star$} \\
\hline PERLND & 26 & PWATER & PERO & 0.32 & RCHRES & 15 & EXTNL & IVOL \\
\hline PERLND & 30 & PWATER & PERO & 25.01 & RCHRES & 15 & EXTNL & IVOL \\
\hline PERLND & 34 & PWATER & PERO & 6.17 & RCHRES & 15 & EXTNL & IVOL \\
\hline PERLND & 34 & PWATER & IGWI & 6.17 & RCHRES & 56 & EXTNL & IVOL \\
\hline IMPLND & 2 & IWATER & SURO & 16.31 & RCHRES & 56 & EXTNL & IVOL \\
\hline \multicolumn{9}{|c|}{ 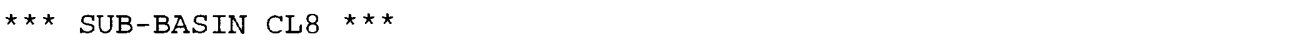 } \\
\hline PERLND & 2 & PWATER & PERO & 0.14 & RCHRES & 16 & EXTNL & IVOL \\
\hline PERLND & 2 & PWATER & IGWI & 0.14 & RCHRES & 56 & EXTNL & IVOL \\
\hline PERLND & 10 & PWATER & PERO & 0.55 & RCHRES & 16 & EXTNL & IVOL \\
\hline PERLND & 10 & PWATER & IGWI & 0.55 & RCHRES & 56 & EXTNL & IVOL \\
\hline PERLND & 14 & PWATER & PERO & 7.43 & RCHRES & 16 & EXTNL & IVOL \\
\hline PERLND & 14 & PWATER & IGWI & 7.43 & RCHRES & 56 & EXTNL & IVOL \\
\hline PERLND & 22 & PWATER & PERO & 1.02 & RCHRES & 16 & EXTNL & IVOL \\
\hline PERLND & 22 & PWATER & IGWI & 1.02 & RCHRES & 56 & EXTNL & IVOL \\
\hline PERLND & 26 & PWATER & PERO & 1.79 & RCHRES & 16 & EXTNL & IVOL \\
\hline PERLND & 30 & PWATER & PERO & 52.79 & RCHRES & 16 & EXTNL & IVOL \\
\hline PERLND & 34 & PWATER & PERO & 8.18 & RCHRES & 16 & EXTNL & IVOL \\
\hline PERLND & 34 & PWATER & IGWI & 8.18 & RCHRES & 56 & EXTNL & IVOL \\
\hline IMPLND & 2 & IWATER & SURO & 35.69 & RCHRES & 56 & EXTNL & IVOL \\
\hline \multicolumn{9}{|c|}{ 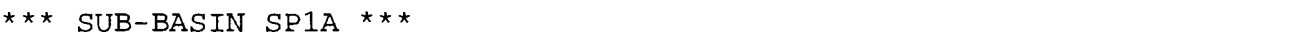 } \\
\hline PERLND & 28 & PWATER & PERO & 67.02 & RCHRES & 17 & EXTNL & IVOL \\
\hline PERLND & 32 & PWATER & PERO & 47.40 & RCHRES & 17 & EXTNL & IVOL \\
\hline PERLND & 36 & PWATER & PERO & 23.77 & RCHRES & 17 & EXTNL & IVOL \\
\hline PERLND & 36 & PWATER & IGWI & 23.77 & RCHRES & 56 & EXTNL & IVOL \\
\hline IMPLND & 4 & IWATER & SURO & 1.52 & RCHRES & 17 & EXTNL & IVOL \\
\hline \multicolumn{9}{|c|}{ 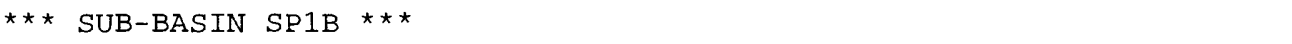 } \\
\hline PERLND & 4 & PWATER & PERO & 21.58 & RCHRES & 56 & EXTNL & IVOL \\
\hline PERLND & 4 & PWATER & IGWI & 21.58 & RCHRES & 56 & EXTNL & IVOL \\
\hline PERLND & 8 & PWATER & PERO & 2.78 & RCHRES & 56 & EXTNL & IVOL \\
\hline PERLND & 8 & PWATER & IGWI & 2.78 & RCHRES & 56 & EXTNL & IVOL \\
\hline PERLND & 12 & PWATER & PERO & 2.44 & RCHRES & 56 & EXTNL & IVOL \\
\hline PERLND & 12 & PWATER & IGWI & 2.44 & RCHRES & 56 & EXTNL & IVOL \\
\hline PERLND & 16 & PWATER & PERO & 16.10 & RCHRES & 56 & EXTNL & IVOL \\
\hline PERLND & 16 & PWATER & IGWI & 16.10 & RCHRES & 56 & EXTNL & IVOL \\
\hline
\end{tabular}


Table 16.--Input sequence of the Clover Creek Basin model used to run Hydrological Simulation Program-FORTRAN (HSPF)--Cont.

\begin{tabular}{|c|c|c|c|c|c|c|c|c|}
\hline PERLND & 20 & PWATER & PERO & 5.87 & RCHRES & 56 & EXTNL & IVOL \\
\hline PERLND & 20 & PWATER & IGWI & 5.87 & RCHRES & 56 & EXTNL & IVOL \\
\hline PERLND & 24 & PWATER & PERO & 2.68 & RCHRES & 56 & EXTNL & IVOL \\
\hline PERLND & 24 & PWATER & IGWI & 2.68 & RCHRES & 56 & EXTNL & IVOL \\
\hline PERLND & 28 & PWATER & PERO & 240.81 & RCHRES & 56 & EXTNL & IVOL \\
\hline PERLND & 32 & PWATER & PERO & 263.85 & RCHRES & 56 & EXTNL & IVOL \\
\hline PERLND & 36 & PWATER & PERO & 9.58 & RCHRES & 56 & EXTNL & IVOL \\
\hline PERLND & 36 & PWATER & IGWI & 9.58 & RCHRES & 56 & EXTNL & IVOL \\
\hline IMPLND & 4 & IWATER & SURO & 43.90 & RCHRES & 56 & EXTNL & IVOL \\
\hline \multicolumn{9}{|c|}{$\star \star \star$ SUB-BASIN SP $2 \quad \star \star \star$} \\
\hline PERLND & 14 & PWATER & PERO & 0.39 & RCHRES & 18 & EXTNL & IVOL \\
\hline PERLND & 14 & PWATER & IGWI & 0.39 & RCHRES & 56 & EXTNL & IVOL \\
\hline PERLND & 26 & PWATER & PERO & 21.96 & RCHRES & 18 & EXTNL & IVOL \\
\hline PERLND & 30 & PWATER & PERO & 93.90 & RCHRES & 18 & EXTNL & IVOL \\
\hline PERLND & 34 & PWATER & PERO & 7.75 & RCHRES & 18 & EXTNL & IVOL \\
\hline PERLND & 34 & PWATER & IGWI & 7.75 & RCHRES & 56 & EXTNL & IVOL \\
\hline IMPLND & 2 & IWATER & SURO & 27.81 & RCHRES & 56 & EXTNL & IVOL \\
\hline \multicolumn{9}{|c|}{ 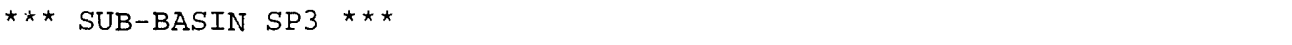 } \\
\hline PERLND & 26 & PWATER & PERO & 1.51 & RCHRES & 56 & EXTNL & IVOL \\
\hline PERLND & 30 & PWATER & PERO & 3.66 & RCHRES & 56 & EXTNL & IVOL \\
\hline IMPLND & 2 & IWATER & SURO & 6.31 & RCHRES & 19 & EXTNL & IVOL \\
\hline \multicolumn{9}{|c|}{ 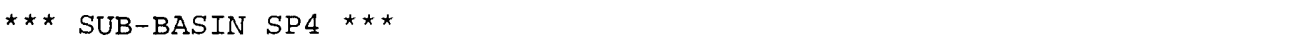 } \\
\hline PERLND & 26 & PWATER & PERO & 9.35 & RCHRES & 20 & EXTNL & IVOL \\
\hline PERLND & 30 & PWATER & PERO & 9.73 & RCHRES & 20 & EXTNL & IVOL \\
\hline PERLND & 34 & PWATER & PERO & 1.19 & RCHRES & 20 & EXTNL & IVOL \\
\hline PERLND & 34 & PWATER & IGWI & 1.19 & RCHRES & 56 & EXTNL & IVOL \\
\hline IMPLND & 2 & IWATER & SURO & 3.43 & RCHRES & 56 & EXTNL & IVOL \\
\hline \multicolumn{9}{|c|}{ 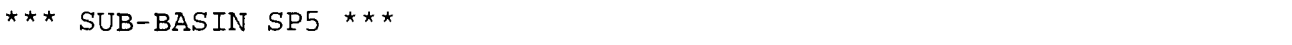 } \\
\hline PERLND & 26 & PWATER & PERO & 6.24 & RCHRES & 21 & EXTNL & IVOL \\
\hline PERLND & 30 & PWATER & PERO & 13.05 & RCHRES & 21 & EXTNL & IVOL \\
\hline PERLND & 34 & PWATER & PERO & 5.78 & RCHRES & 21 & EXTNL & IVOL \\
\hline PERLND & 34 & PWATER & IGWI & 5.78 & RCHRES & 56 & EXTNL & IVOL \\
\hline IMPLND & 2 & IWATER & SURO & 2.90 & RCHRES & 56 & EXTNL & IVOL \\
\hline \multicolumn{9}{|c|}{ 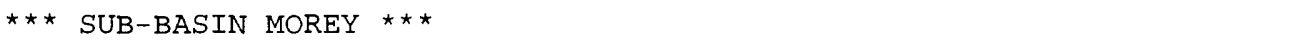 } \\
\hline PERLND & 26 & PWATER & PERO & 8.15 & RCHRES & 22 & EXTNL & IVOL \\
\hline PERLND & 30 & PWATER & PERO & 7.10 & RCHRES & 22 & EXTNL & IVOL \\
\hline PERLND & 34 & PWATER & PERO & 0.78 & RCHRES & 22 & EXTNL & IVOL \\
\hline PERLND & 34 & PWATER & IGWI & 0.78 & RCHRES & 56 & EXTNL & IVOL \\
\hline IMPLND & 2 & IWATER & SURO & 0.85 & RCHRES & 22 & EXTNL & IVOL \\
\hline \multicolumn{9}{|c|}{$\star \star \star$ SUB-BASIN CL $9 \star \star \star *$} \\
\hline PERLND & 26 & PWATER & PERO & 8.10 & RCHRES & 23 & EXTNL & IVOL \\
\hline PERLND & 30 & PWATER & PERO & 86.74 & RCHRES & 23 & EXTNL & IVOL \\
\hline PERLND & 34 & PWATER & PERO & 2.88 & RCHRES & 23 & EXTNL & IVOL \\
\hline PERLND & 34 & PWATER & IGWI & 2.88 & RCHRES & 56 & EXTNL & IVOL \\
\hline IMPLND & 2 & IWATER & SURO & 67.52 & RCHRES & 56 & EXTNL & IVOL \\
\hline \multicolumn{9}{|c|}{$\star \star \star$ SUB-BASIN CLI0 $\star \star \star *$} \\
\hline PERLND & 18 & PWATER & PERO & 0.42 & RCHRES & 24 & EXTNL & IVOL \\
\hline PERLND & 18 & PWATER & IGWI & 0.42 & RCHRES & 56 & EXTNL & IVOL \\
\hline PERLND & 22 & PWATER & PERO & 0.33 & RCHRES & 24 & EXTNL & IVOL \\
\hline PERLND & 22 & PWATER & IGWI & 0.33 & RCHRES & 56 & EXTNL & IVOL \\
\hline PERLND & 26 & PWATER & PERO & 8.79 & RCHRES & 24 & EXTNL & IVOL \\
\hline PERLND & 30 & PWATER & PERO & 17.92 & RCHRES & 24 & EXTNL & IVOL \\
\hline PERLND & 34 & PWATER & PERO & 0.31 & RCHRES & 24 & EXTNL & IVOL \\
\hline PERLND & 34 & PWATER & IGWI & 0.31 & RCHRES & 56 & EXTNL & IVOL \\
\hline IMPLND & 2 & IWATER & SURO & 12.58 & RCHRES & 24 & EXTNL & IVOL \\
\hline
\end{tabular}

$\star \star \star$

$\star \star \star$ CHANNEL NETWORK LINKAGES $* \star *$

$\star \star \star$ 


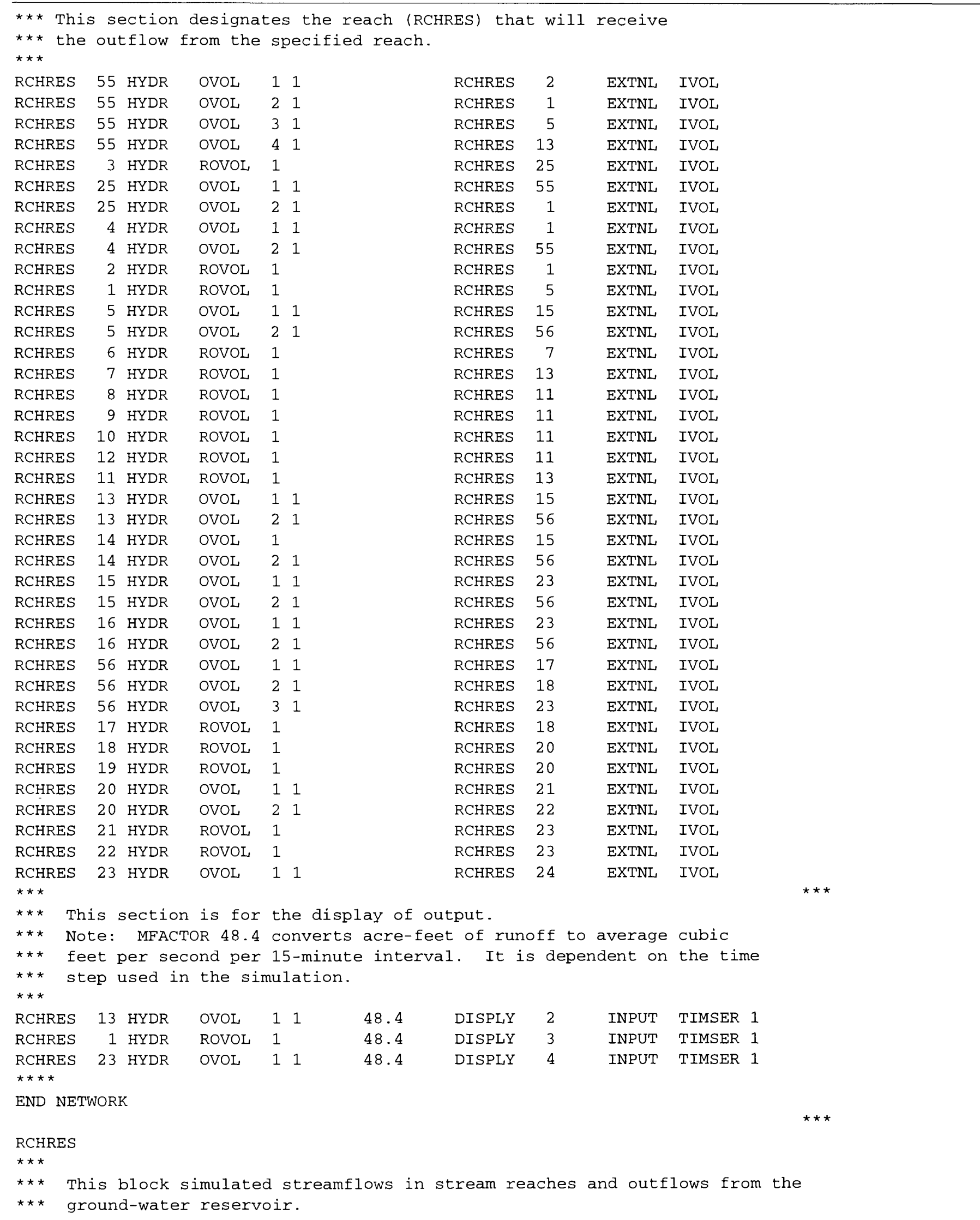




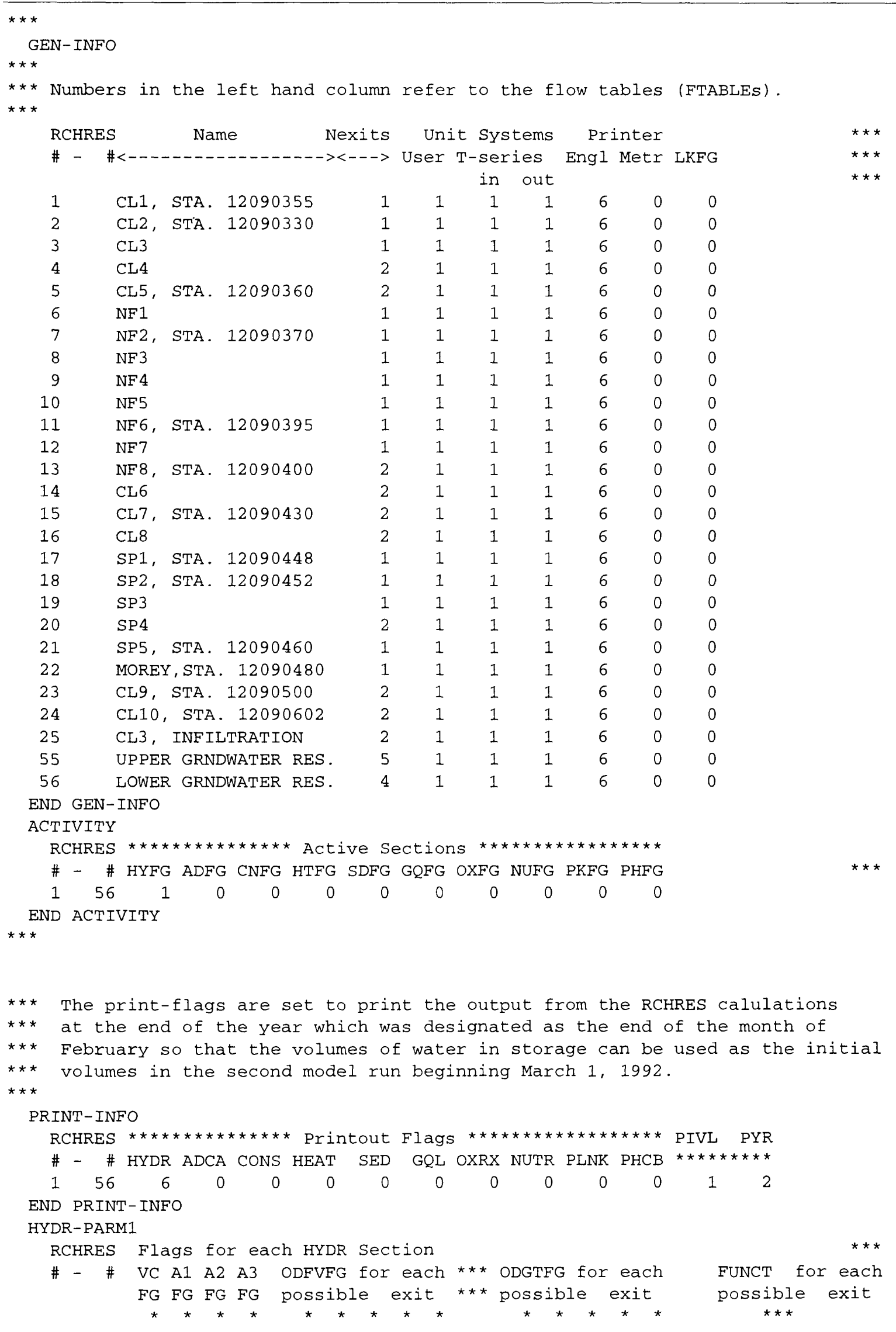


Table 16.--Input sequence of the Clover Creek Basin model used to run Hydrological Simulation Program-FORTRAN (HSPF)--Cont.

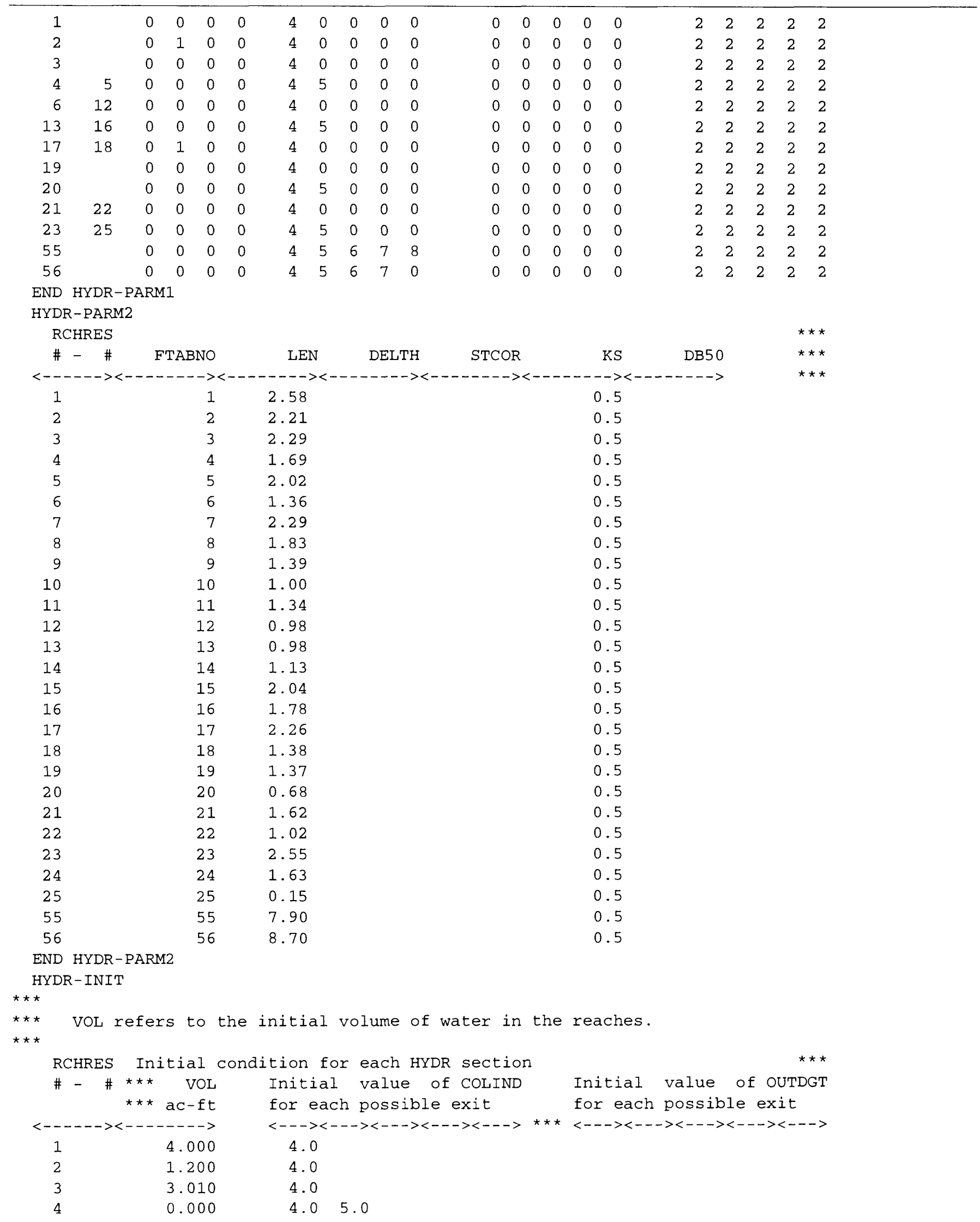




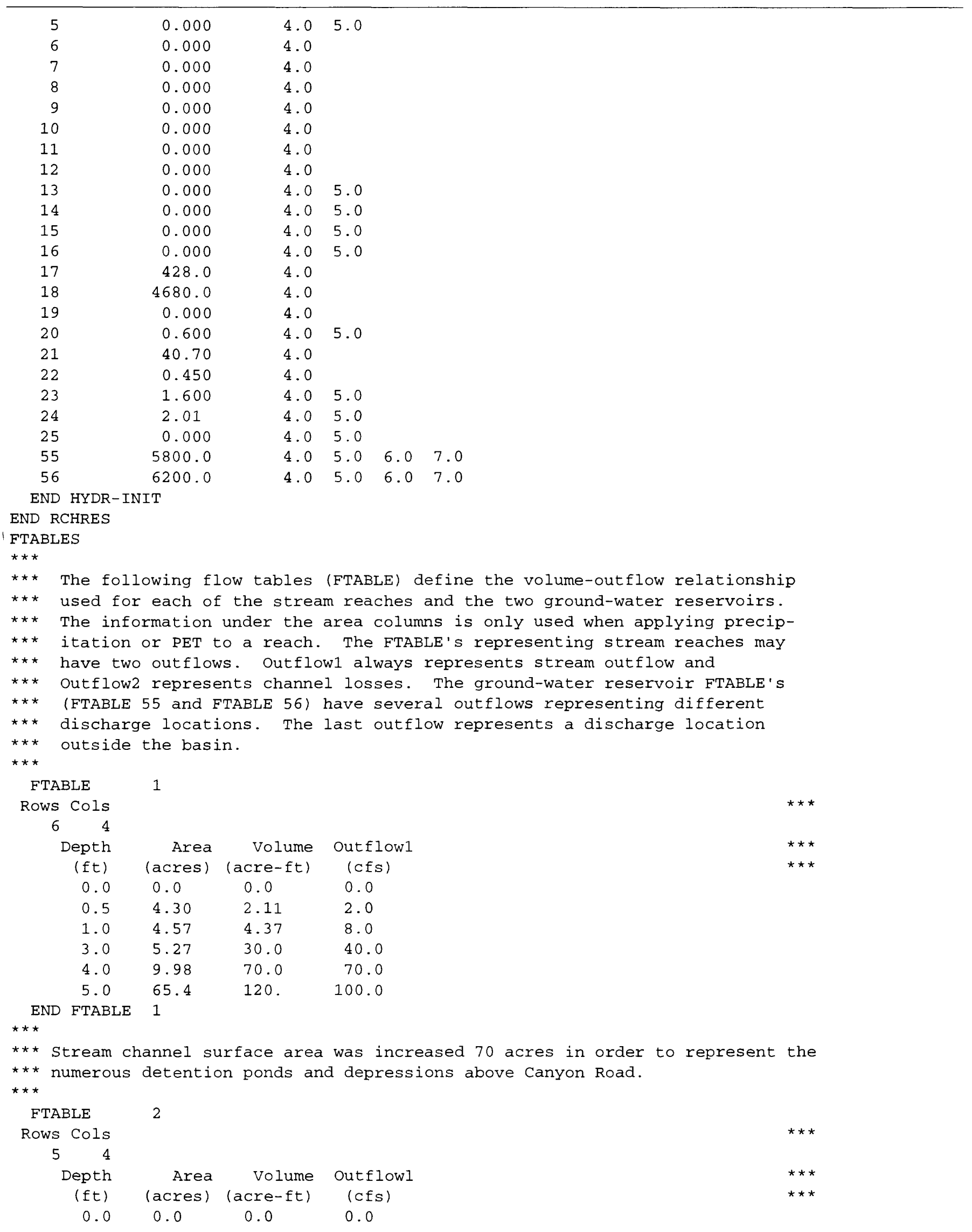


Table 16.--Input sequence of the Clover Creek Basin model used to run Hydrological Simulation Program-FORTRAN (HSPF)--Cont.

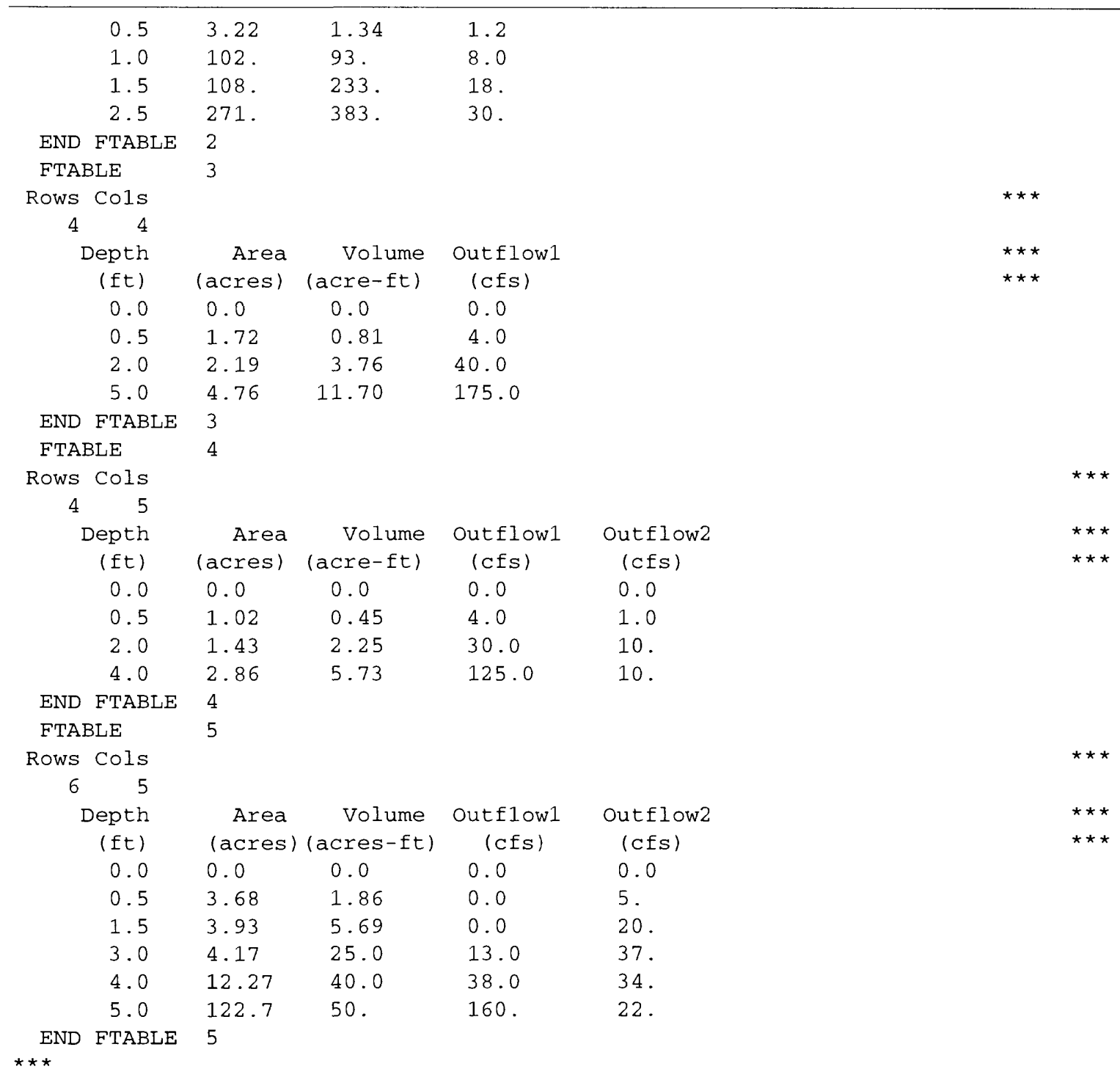

\footnotetext{
*** The following is FTABLE 5 that is used in the second model run beginning on

$\star * \star$ March 1, 1992, and that runs through September 30, 1992. It represents the change

*** to RCHRES 5 caused by restoration projects on this portion of Clover Creek

*** that were designed to reduce channel losses. The first FTABLE 5 is used in

*** a model run from october 1, 1990, to February 29, 1992, and all the final

$\star \star \star$ storages for the land segments and reaches and used as the intial storages

$\star \star *$ for the second run beginning March 1, 1992. Also, the FTABLE 5 shown below

$\star \star *$ is substituted for FTABLE 5 shown above.

$\star \star \star$

$* * *$ FTABLE 5

$\star \star \star$ Rows Cols

$\star * \star \quad 6 \quad 5$

$\star \star \star \quad$ Depth

$\star \star \star \quad$ (ft)

$\star \star \star \quad 0.0$

Volume Outflow1 Outflow2

0.0

(acres) (acres-ft)

$(c f s)$

(cfs)

*** $\quad 0.5$

0.0

0.0

0.0

0.0

1. 5

3. 68

1.86

0.8

4.2

3.0

4.17

5.69

6.0

14.

25.0

13.0

37.
} 
Table 16.--Input sequence of the Clover Creek Basin model used to run Hydrological Simulation Program-FORTRAN (HSPF)--Cont.

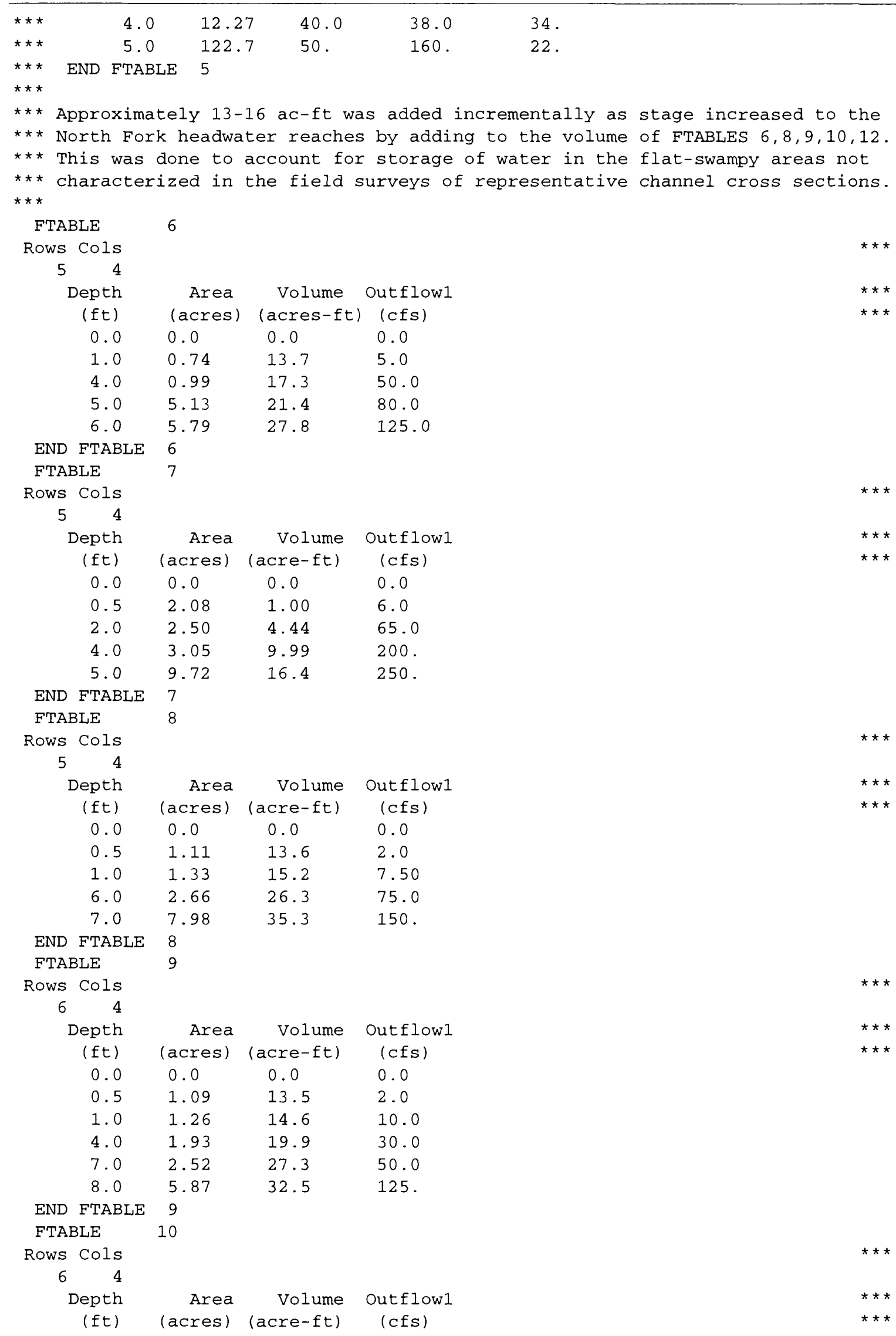


Table 16.--Input sequence of the Clover Creek Basin model used to run Hydrological Simulation Program-FORTRAN (HSPF)--Cont.

\begin{tabular}{|c|c|c|c|c|c|}
\hline C. 0 & 0.0 & 0.0 & 0.0 & & \\
\hline 0.5 & 0.55 & 13.3 & 2.0 & & \\
\hline 1.0 & 0.61 & 14.1 & 7.0 & & \\
\hline 4.0 & 0.97 & 16.9 & 35.0 & & \\
\hline 8.0 & 1.46 & 22.8 & 70.0 & & \\
\hline 9.0 & 4.26 & 25.2 & 125 . & & \\
\hline END FTABLE & 10 & & & & \\
\hline FTABLE & 11 & & & & \\
\hline $\begin{array}{rr}\text { Rows } & \text { Cols } \\
4 & 4\end{array}$ & & & & & $\star \star \star ~ *$ \\
\hline Depth & Area & Volume & Outflowl & & $\star \star \star$ \\
\hline$(f t)$ & (acres) & (acre-ft) & (cfs) & & $\star \star \star$ \\
\hline 0.0 & 0.0 & 0.0 & 0.0 & & \\
\hline 0.5 & 1.46 & 0.68 & 5.0 & & \\
\hline 2.0 & 1.95 & 3.25 & 65.0 & & \\
\hline 10.0 & 4.23 & 27.7 & 1000 & & \\
\hline END FTABLE & 11 & & & & \\
\hline FTABLE & 12 & & & & \\
\hline $\begin{array}{rr}\text { Rows } & \text { Cols } \\
5 & 4\end{array}$ & & & & & $\star \star \star$ \\
\hline Depth & Area & Volume & Outflow1 & & $\star \star \star$ \\
\hline$(f t)$ & (acres) & $($ acre-ft) & (cfs) & & $\star \star \star$ \\
\hline 0.0 & 0.0 & 0.0 & 0.0 & & \\
\hline 0.4 & 0.60 & 13.2 & 2.0 & & \\
\hline 1.0 & 0.72 & 14.6 & 10.0 & & \\
\hline 4.0 & 1.67 & 19.3 & 200 & & \\
\hline 10.0 & 2.58 & 36.3 & 1000 . & & \\
\hline END FTABLE & 12 & & & & \\
\hline FTABLE & 13 & & & & \\
\hline Rows Cols & & & & & $\star \star \star$ \\
\hline 75 & & & & & \\
\hline Depth & Area & Volume & Outflow1 & outf1ow2 & $\star \star \star$ \\
\hline$(f t)$ & (acres) & (acre-ft) & (cfs) & $(\mathrm{cfs})$ & $\star \star \star$ \\
\hline 0.0 & 0.0 & 0.0 & 0.0 & 0.0 & \\
\hline 0.3 & 0.5 & 0.3 & 0.0 & 3.0 & \\
\hline 0.5 & 1.49 & 0.8 & 2.0 & 4.0 & \\
\hline 3.0 & 1.67 & 5.0 & 100 & 5.0 & \\
\hline 6.0 & 1.90 & 10.0 & 360. & 5.0 & \\
\hline 7.0 & 4.17 & 13.0 & 390. & 5.0 & \\
\hline 8.0 & 12 & 21.0 & 430 & 5.0 & \\
\hline END FTABLE & 13 & & & & \\
\hline FTABLE & 14 & & & & \\
\hline $\begin{array}{rr}\text { Rows } & \text { Cols } \\
4 & 5\end{array}$ & & & & & $\star \star \star$ \\
\hline Depth & Area & Volume & Outflow1 & Outflow2 & $\star \star \star$ \\
\hline$(f t)$ & (acres) & $($ acre-ft) & (cfs) & (cfs) & $\star \star \star$ \\
\hline 0.0 & 0.0 & 0.0 & 0.0 & 0.0 & \\
\hline 0.5 & 0.82 & 0.38 & 0.0 & 3.0 & \\
\hline 3.0 & 1.24 & 2.89 & 0.0 & 45. & \\
\hline 4.0 & 1.24 & 4.12 & 10.0 & 65. & \\
\hline END FTABLE & 14 & & & & \\
\hline FTABLE & 15 & & & & \\
\hline Rows Cols & & & & & $\star \star \star$ \\
\hline 65 & & & & & \\
\hline Depth & Area & Volume & outflow1 & Outflow2 & $\star \star \star$ \\
\hline$(f t)$ & (acres) & $(\operatorname{acre}-\mathrm{ft})$ & $(\mathrm{cfs})$ & (cfs) & $\star \star \star$ \\
\hline 0.0 & 0.0 & 0.0 & 0.0 & 0.0 & \\
\hline 0.5 & 2.97 & 1.49 & 3.0 & 2.0 & \\
\hline
\end{tabular}


Table 16.--Input sequence of the Clover Creek Basin model used to run Hydrological Simulation Program-FORTRAN (HSPF)--Cont.

\begin{tabular}{|c|c|c|c|c|c|}
\hline 2.0 & 3.46 & 6.32 & 20. & 20. & \\
\hline 4.0 & 3.84 & 13.6 & 50 & 40 & \\
\hline 9.0 & 22 & 200 & 150. & 100. & \\
\hline 10 & 30 & 300 & 230 & 120 . & \\
\hline END FTABLE & 15 & & & & \\
\hline FTABLE & 16 & & & & \\
\hline $\begin{array}{rr}\text { Rows } & \text { Cols } \\
4 & 5\end{array}$ & & & & & $\star \star \star \star$ \\
\hline Depth & Area & Volume & Outflowl & Outf1ow2 & $\star \star \star *$ \\
\hline$(f t)$ & (acres) & $($ acre-ft) & (cfs) & (cfs) & $\star \star *$ \\
\hline 0.0 & 0.0 & 0.0 & 0.0 & 0.0 & \\
\hline 0.5 & 1.29 & 0.65 & 0.0 & 1.0 & \\
\hline 2.0 & 1.51 & 2.80 & 0.0 & 16. & \\
\hline 4.0 & 1.72 & 6.03 & 4.0 & 46. & \\
\hline END FTABLE & 16 & & & & \\
\hline FTABLE & 17 & & & & \\
\hline $\begin{array}{rr}\text { Rows } & \text { Cols } \\
6 & 4\end{array}$ & & & & & $* * *$ \\
\hline Depth & Area & Volume & outflow 1 & & $* * *$ \\
\hline$(f t)$ & (acres) & $(\operatorname{acre}-\mathrm{ft}\rangle$ & $(\mathrm{Cfs})$ & & $\star \star \star$ \\
\hline 0.0 & 0.0 & 0.0 & 0.0 & & \\
\hline 3.0 & 137. & 410 & 0.0 & & \\
\hline 3.1 & 137. & 424 . & 1.00 & & \\
\hline 3.5 & 140. & 479. & 10.0 & & \\
\hline 4.0 & 145 . & 547. & 30.0 & & \\
\hline 6.0 & 150 & 821. & 150 . & & \\
\hline END FTABLE & 17 & & & & \\
\hline FTABLE & 18 & & & & \\
\hline $\begin{array}{rr}\text { Rows } & \text { Cols } \\
6 & 4\end{array}$ & & & & & $* * *$ \\
\hline Depth & Area & Volume & outflow1 & & $\star \star \star$ \\
\hline$(f t)$ & (acres) & $(\operatorname{acre}-\mathrm{ft})$ & (cfs) & & $\star \star *$ \\
\hline 0.0 & 0.0 & 0.0 & 0.0 & & \\
\hline 16.0 & 280 & 4600 & 0.0 & & \\
\hline 16.1 & 280. & 4630 . & 2.0 & & \\
\hline 16.5 & 285. & 4740 . & 10.0 & & \\
\hline 17.0 & 300 & 4890 & 75.0 & & \\
\hline 18.0 & 310 & 5175 . & 200 & & \\
\hline$\underset{\star \star \star}{\text { END FTABLE }}$ & 18 & & & & \\
\hline $\begin{array}{l}\star \star \star \\
\star \star \star\end{array}$ & 9 is a st & orm drain & system. & & \\
\hline FTABLE & 19 & & & & \\
\hline $\begin{array}{rr}\text { Rows } & \text { Cols } \\
4 & 4\end{array}$ & & & & & $\star \star \star *$ \\
\hline Depth & Area & Volume & Outflow1 & & $\star \star \star$ \\
\hline$(f t)$ & (acres) & $($ acre- $f t)$ & (cfs) & & $\star \star \star$ \\
\hline 0.0 & 0.0 & 0.0 & 0.0 & & \\
\hline 0.5 & 0.33 & 0.12 & 2.0 & & \\
\hline 1.2 & 0.41 & 0.41 & 10.0 & & \\
\hline 2.5 & 0.41 & 0.81 & 75.0 & & \\
\hline END FTABLE & 19 & & & & \\
\hline$\star \star \star$ & & & & & \\
\hline $\begin{array}{ll}\star \star \star & \text { Outflow } 1 \\
\star \star \star & \text { (RCHRES }\end{array}$ & $\begin{array}{l}\text { goes to } \\
22 \text { ) }\end{array}$ & Tule Lake & (RCHRES 21) & and Outflow2 goes to Morey Creek & \\
\hline$\star \star \star$ & & & & & \\
\hline FTABLE & 20 & & & & \\
\hline $\begin{array}{rr}\text { Rows } & \text { Cols } \\
5 & 5\end{array}$ & & & & & $\star \star \star$ \\
\hline
\end{tabular}


Table 16.--Input sequence of the Clover Creek Basin model used to run Hydrological Simulation Program-FORTRAN (HSPF)--Cont.

\begin{tabular}{|c|c|c|c|c|c|}
\hline $\begin{array}{c}\text { Depth } \\
(f t)\end{array}$ & $\begin{array}{r}\text { Area } \\
\text { (acres) }\end{array}$ & $\begin{array}{r}\text { Volume } \\
\text { (acre-ft) }\end{array}$ & $\begin{array}{l}\text { Outflow1 } \\
\text { (cfs) }\end{array}$ & $\begin{array}{l}\text { Outflow2 } \\
\text { (cfs) }\end{array}$ & $\begin{array}{l}\star \star \star \\
\star \star \star\end{array}$ \\
\hline 0.0 & 0.0 & 0.0 & 0.0 & 0.0 & \\
\hline 0.5 & 0.75 & 0.35 & 2.5 & 2.5 & \\
\hline 2.0 & 1.00 & 1.66 & 40.0 & 9.0 & \\
\hline 3.0 & 1.66 & 2.99 & 110. & 20.0 & \\
\hline 6.0 & 1.99 & 8.46 & 500 & 80.0 & \\
\hline END FTABLE & 20 & & & & \\
\hline FTABLE & 21 & & & & \\
\hline $\begin{array}{rr}\text { Rows } & \text { Cols } \\
5 & 4\end{array}$ & & & & & $\star \star \star$ \\
\hline $\begin{array}{r}\text { Depth } \\
(f t)\end{array}$ & $\begin{array}{r}\text { Area } \\
\text { (acres) }\end{array}$ & $\begin{array}{r}\text { Volume } \\
\text { (acre-ft) }\end{array}$ & $\begin{array}{l}\text { Outflow1 } \\
\text { (cfs) }\end{array}$ & & $\begin{array}{l}\star \star \star \\
\star \star \star\end{array}$ \\
\hline 0.0 & 0.0 & 0.0 & 0.0 & & \\
\hline 0.5 & 9.12 & 40.5 & 2.0 & & \\
\hline 2.0 & 9.50 & 42.5 & 20.0 & & \\
\hline 5.0 & 13.5 & 80.0 & 150. & & \\
\hline 7.0 & 14.8 & 107. & 325 . & & \\
\hline END FTABLE & 21 & & & & \\
\hline FTABLE & 22 & & & & \\
\hline $\begin{array}{rr}\text { Rows } & \text { Cols } \\
5 & 4\end{array}$ & & & & & $\star \star \star$ \\
\hline $\begin{array}{c}\text { Depth } \\
(f t)\end{array}$ & $\begin{array}{r}\text { Area } \\
\text { (acres) }\end{array}$ & $\begin{array}{r}\text { Volume } \\
\text { (acre-ft) }\end{array}$ & $\begin{array}{l}\text { Outflow1 } \\
\text { (cfs) }\end{array}$ & & $\begin{array}{l}\star \star \star \\
\star \star \star\end{array}$ \\
\hline 0.0 & 0.0 & 0.0 & 0.0 & & \\
\hline 0.5 & 0.90 & 0.45 & 3.0 & & \\
\hline 2.0 & 1.16 & 2.06 & 25.0 & & \\
\hline 4.0 & 2.96 & 6.17 & 100 & & \\
\hline 5.0 & 6.43 & 10.86 & 150 . & & \\
\hline END FTABLE & 22 & & & & \\
\hline FTABLE & 23 & & & & \\
\hline $\begin{array}{rr}\text { Rows } & \text { Cols } \\
6 & 5\end{array}$ & & & & & $\star \star \star$ \\
\hline Depth & Area & Volume & Outflow1 & outflow2 & $\star \star \star$ \\
\hline$(f t)$ & (acres) & (acre-ft) & $(\mathrm{cfs})$ & $(c f s)$ & $\star \star \star$ \\
\hline 0.0 & 0.0 & 0.0 & 0.0 & 0.0 & \\
\hline 0.5 & 4.01 & 1.93 & 2.5 & 2.5 & \\
\hline 3.0 & 5.56 & 13.89 & 74.0 & 2.5 & \\
\hline 6.0 & 7.41 & 40 & 100 & 2.5 & \\
\hline 8.0 & 15.43 & 100 . & 200 & 2.5 & \\
\hline 10.0 & 15.43 & 250 & 300 & 2.5 & \\
\hline END FTABLE & 23 & & & & \\
\hline FTABLE & 24 & & & & \\
\hline $\begin{array}{rr}\text { Rows } & \text { Cols } \\
4 & 5\end{array}$ & & & & & $\star \star \star$ \\
\hline $\begin{array}{c}\text { Depth } \\
(f t)\end{array}$ & $\begin{array}{r}\text { Area } \\
\text { (acres) }\end{array}$ & $\begin{array}{r}\text { Volume } \\
\text { (acre-ft) }\end{array}$ & $\begin{array}{l}\text { Outflow } 1 \\
\text { (cfs) }\end{array}$ & $\begin{array}{l}\text { Outflow2 } \\
\text { (cfs) }\end{array}$ & $\begin{array}{l}\star \star \star \\
\star \star \star\end{array}$ \\
\hline 0.0 & 0.0 & 0.0 & 0.0 & 0.0 & \\
\hline 0.5 & 4.14 & 2.01 & 9.0 & 4.0 & \\
\hline 2.0 & 4.73 & 8.67 & 90.0 & 8.0 & \\
\hline 8.0 & 6.31 & 41.77 & 900. & 0.0 & \\
\hline$\underset{\star \star \star}{\text { END FTABLE }}$ & 24 & & & & \\
\hline
\end{tabular}


Table 16.--Input sequence of the Clover Creek Basin model used to run Hydrological Simulation Program-FORTRAN (HSPF)--Cont.

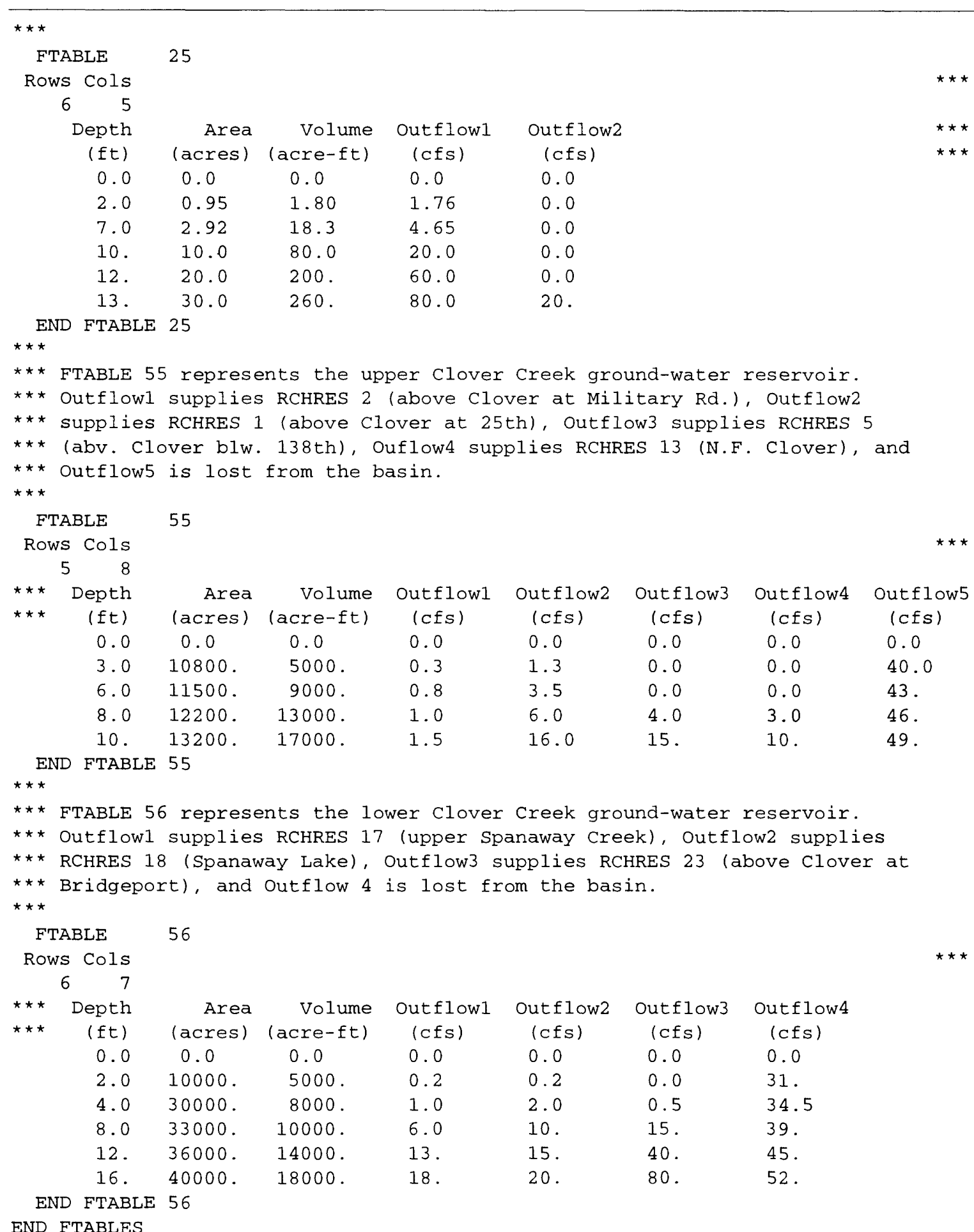

END FTABLES

DISPLY

$\star \star \star$

$\star \star \star$ This block is for displaying time series outputs from the model.

$\star \star \star *$

DISPLY-INFO1

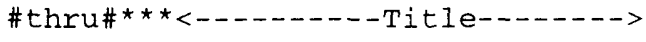

$<-$ short-span->

$<---$ disply---> <annual summary -> 
Table 16.--Input sequence of the Clover Creek Basin model used to run Hydrological Simulation Program-FORTRAN(HSPF)--Cont.

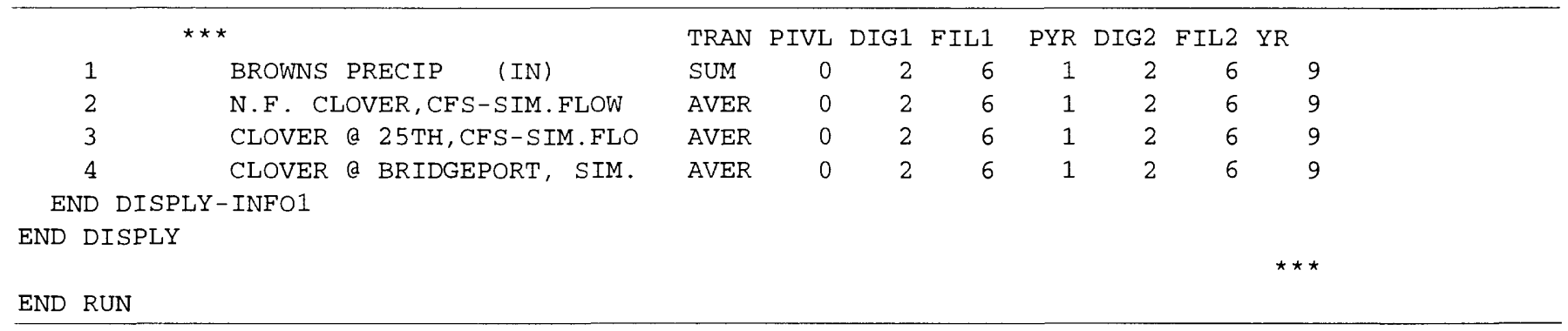

